
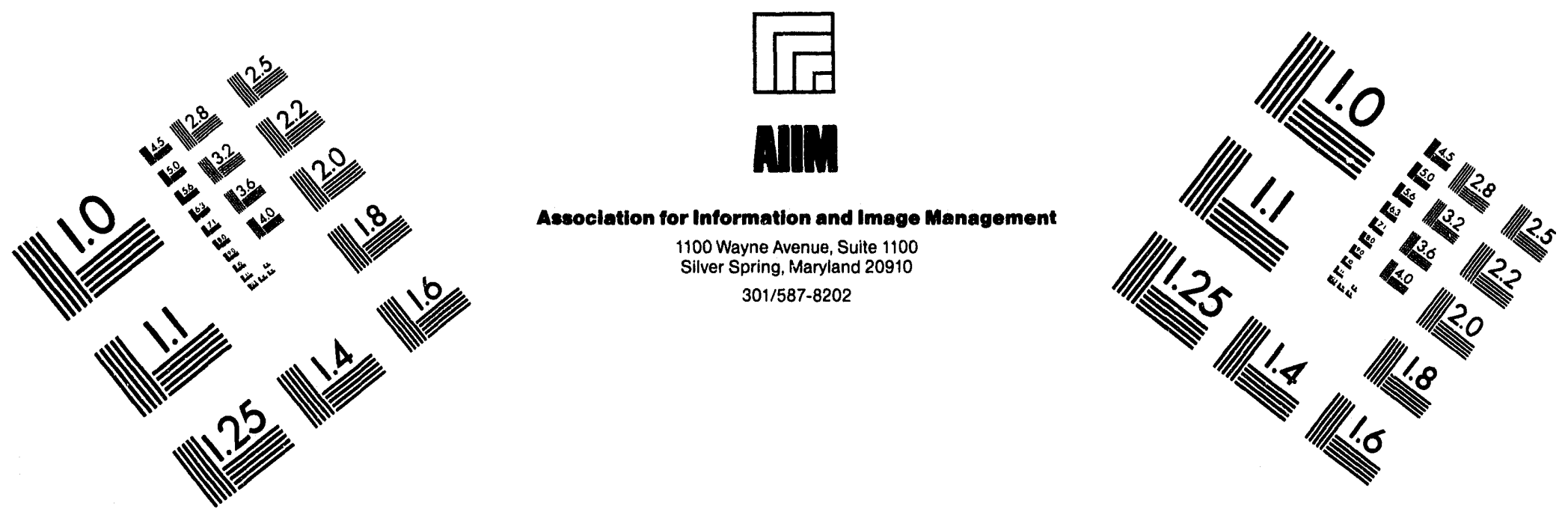

Centimeter

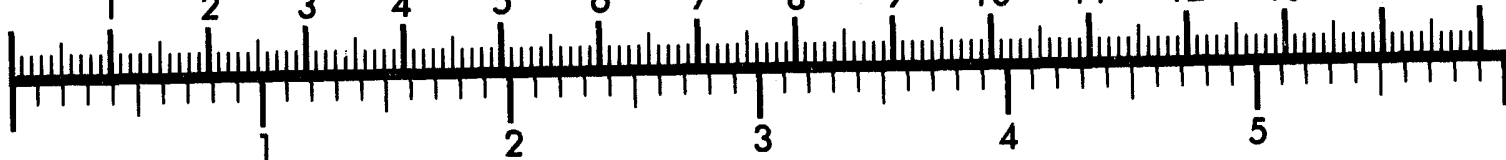
Inches
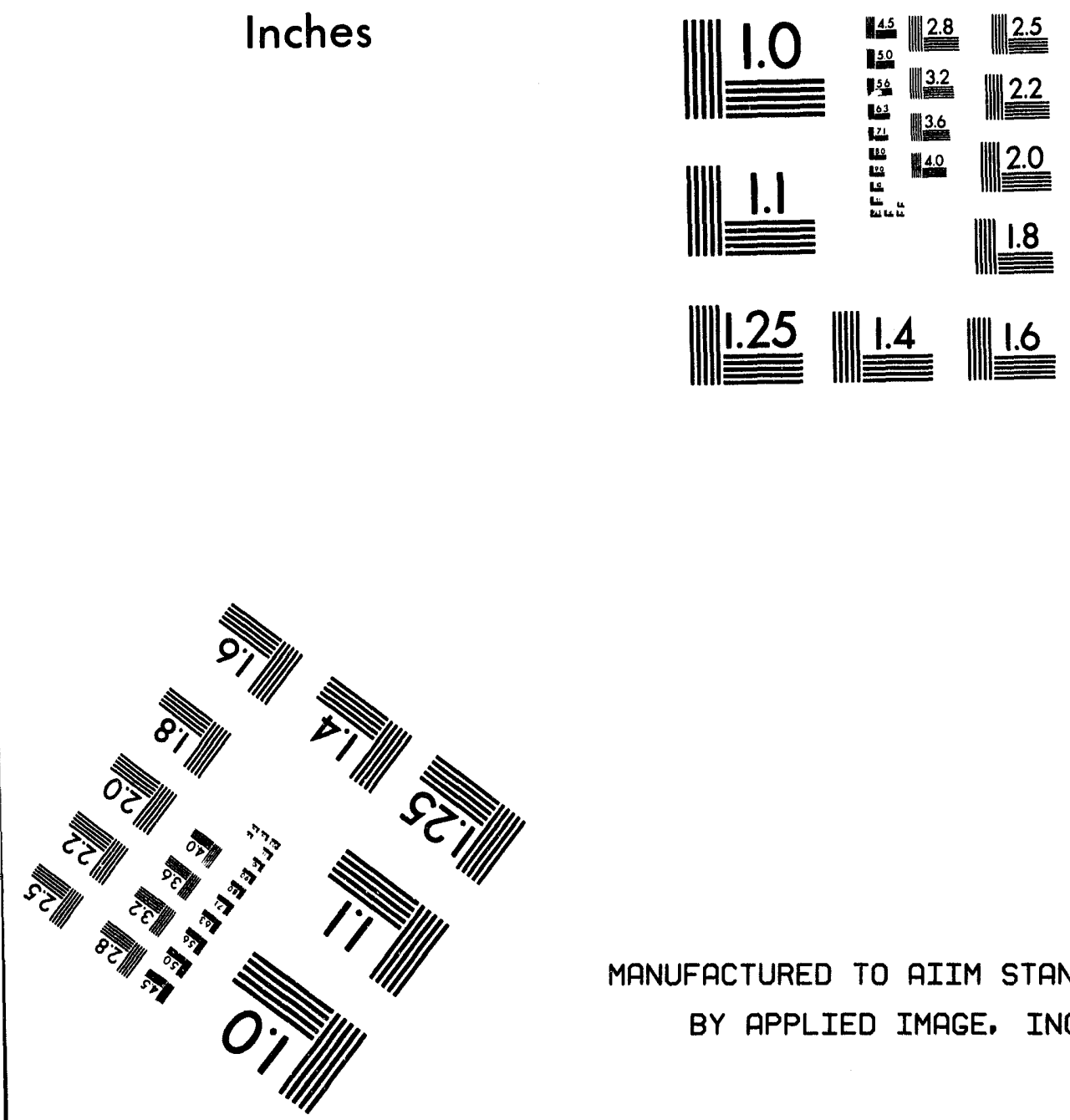

MANUFACTURED TO AIIM STANDARDS

BY APPLIED IMAGE. INC.

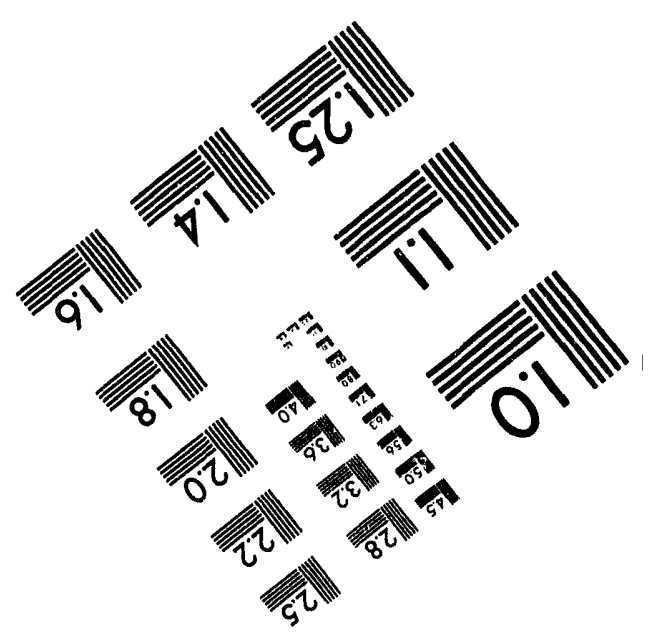



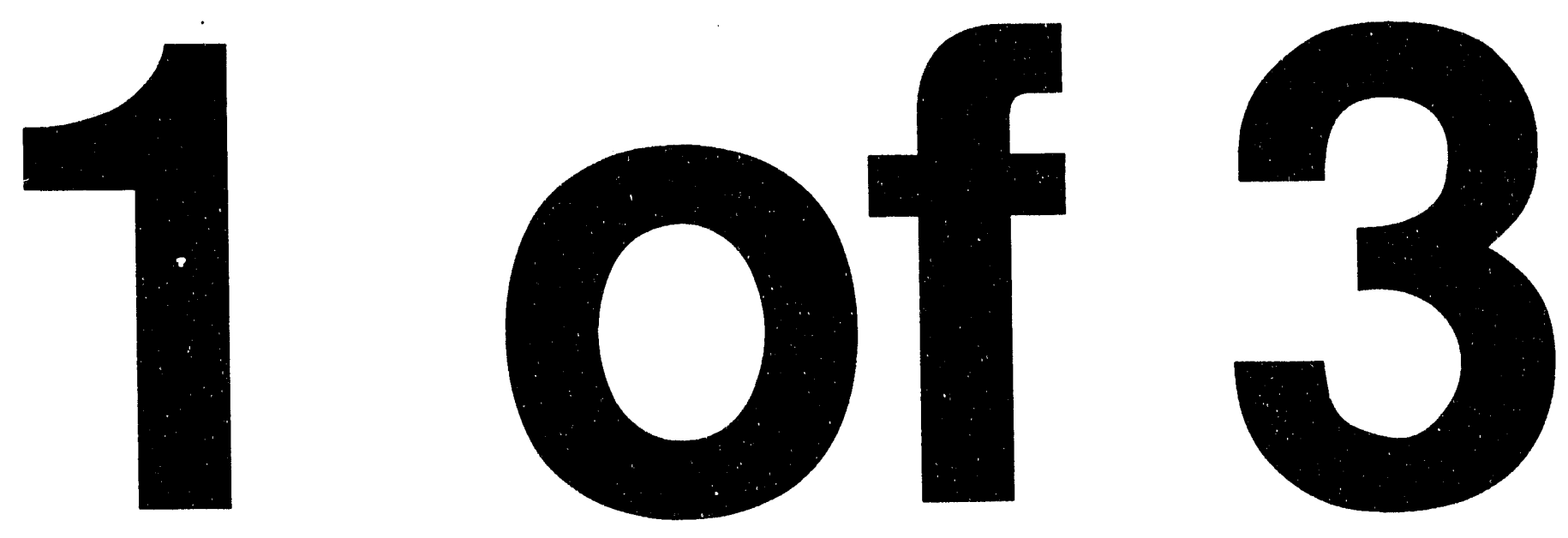
NUREG/CR-6044

SAND93-1049

\section{Experiments to Investigate \\ Direct Containment Heating \\ Phenomena with Scaled Models of \\ the Zion Nuclear Power Plant in \\ the SURTSEY Test Facility}

Manuscript Completed: March 1994

Date Published: May 1994

Prepared by

M. D. Allen, M. M. Pilch, T. K. Blanchat, R. O. Griffith

R. T. Nichols*

Sandia National Laboratories

Albuquerque, NM 87185

Prepared for

Division of Systems Research

Office of Nuclear Regulatory Research

U.S. Nuclear Regulatory Commission

Washington, DC 20555-0001

NRC FIN A1406

*Ktech Corp., 901 Pennsylvania NE, Albuquerque, NM 87110

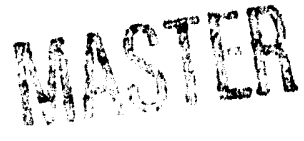

GISHmBUTION OF thIS DOCUMENT IS UNLIMITES 


\begin{abstract}
The Surtsey Facility at Sandia National Laboratories (SNL) is used to perform scaled experiments for the Nuclear Regulatory Commission that simulate hypothetical high-pressure melt ejection (HPME) accidents in a nuclear power plant (NPP). These experiments are designed to investigate the effect of specific phenomena associated with direct containment heating (DCH) on the containment load, such as the effect of physical scale, prototypic subcompartment structures, water in the cavity and on the containment basement floor, and hydrogen generation and combustion.

In the recent Integral Effects Test (IET) series conducted at SNL, 1:10 linear scale models of the bottom head of the reactor pressure vessel (RPV), the cavity, insirument tunnel, and subcompartment structures found in the Zion NPP were constructed. The RPV was modeled with a steel pressure vessel (called the melt generator) that had a hemispherical bottom head. The melt generator had a 4-cm hole in the bottom head that simulated the final ablated hole in the RPV that would be formed by ejection of an instrument guide tube in a severe NPP accident. A $43-\mathrm{kg}$ initial charge of iron/alumina/chromium thermite was used in the melt generator to simulate molten corium that would accumulate on the bottom head of an actual RPV. In the IET series, this chemically reactive melt was ejected by high-pressure steam from the melt generator into the scaled reactor cavity. Debris was then entrained through the instrument tunnel into the subcompartment structures and the upper dome of the simulated reactor containment building.

A two-cell equilibrium model was used to interpret the data from the IET tests. Analyses of the entire DCH database indicate that DCH is insensitive to physical scale and to the exact details of the subcompartment geometry. There are several sources of hydrogen in a HPME. However, the hydrogen produced by steam/metal reactions during the coherent part of the steam blowdown, i.e., when debris was in contact with steam, was the source of hydrogen that made the most significant contribution to containment pressurization. This hydrogen was intimately mixed with a jet of molten debris particles, and thus burned as it entered the upper dome. Preexisting hydrogen in the vessel did not burn on a time scale that contributed to the peak containment pressure.
\end{abstract}




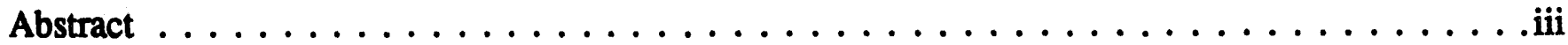

Executive Summary $\ldots \ldots \ldots \ldots \ldots \ldots \ldots \ldots \ldots \ldots \ldots \ldots \ldots \ldots \ldots \ldots \ldots \ldots \ldots \ldots$

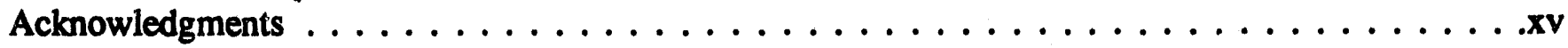

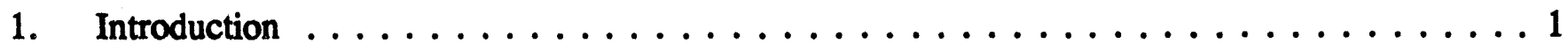

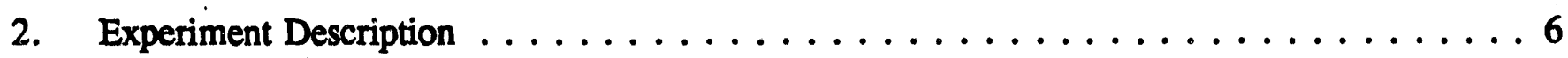

2.1 Geometry and Initial Conditions: The Design Basis $\ldots \ldots \ldots \ldots \ldots$

2.1 .1 Facility Geometry . . . . . . . . . . . . . . . 7

2.1.2 Melt Mass and Composition ................. 9

2.1.3 RCS or Accumulator Conditions . . . . . . . . . . . . . 11

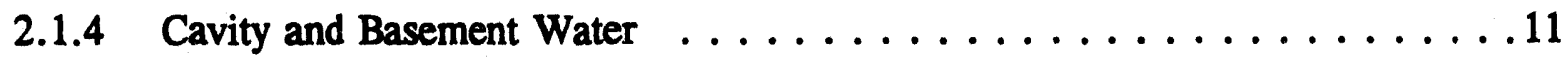

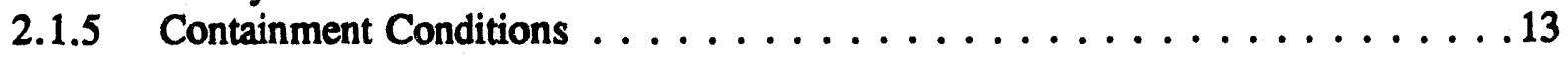

2.2 Measurements and Instrumentation . . . . . . . . . . . . . . 14

2.2.1 Pressure Measurements . . . . . . . . . . . . . . . . 14

2.2.2 Gas Temperature Measurements . . . . . . . . . . . . . . 15

2.2.3 Debris Temperature Measurements . . . . . . . . . . . . 16

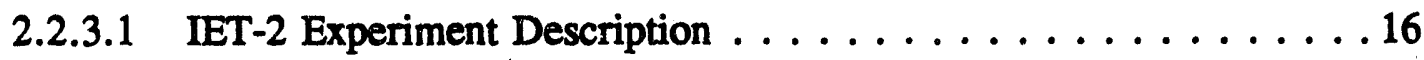

2.2.3.2 IET-2 Instrumentation . . . . . . . . . . . . 17

2.2.4 Gas Composition . . . . . . . . . . . . . . . . . . . 19

2.2.5 Posttest Debris Recovery . . . . . . . . . . . . . . . . . . . 19

2.2 .6 Debris Velocity . . . . . . . . . . . . . . . . . . . 19

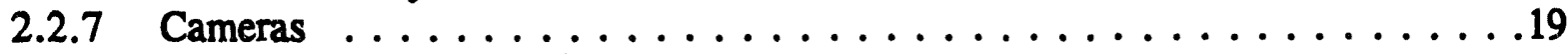

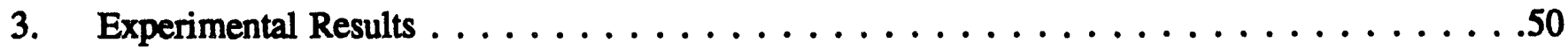

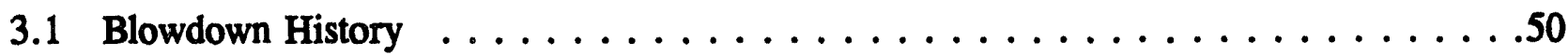

3.2 Pressure Measurements . . . . . . . . . . . . . . . . . 50

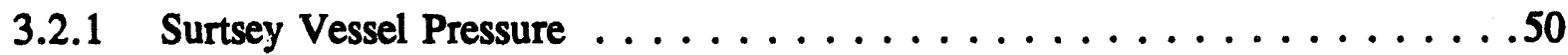

3.2 .2 Cavity Pressure . . . . . . . . . . . . . . . . . .51

3.2.3 Pressure Measured Inside the Seal Table Room . . . . . . . . . . . 52

3.2.4 Pressure Measured Inside the Subcompartment Structures $\ldots \ldots \ldots \ldots 52$ 


\section{Contents (continued)}

Page

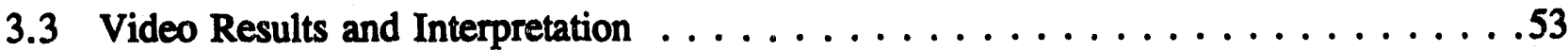

3.4 Debris Temperature Measurements $\ldots \ldots \ldots \ldots \ldots \ldots \ldots \ldots \ldots . \ldots \ldots$

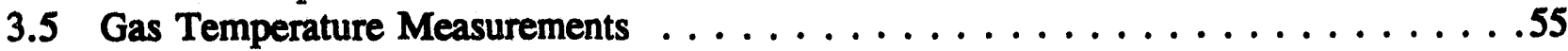

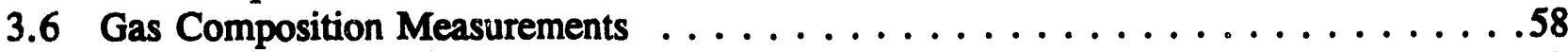

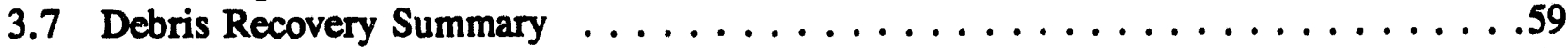

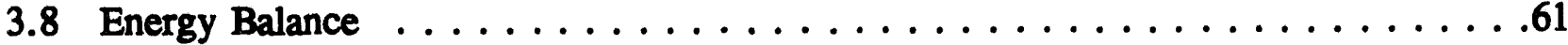

4. Interpretation of Experiment Results with the Two-Cell Model . . . . . . . . . . . 140

4.1 Computation of the Coherence Ratio . . . . . . . . . . . . . . . 140

4.2 Transport Fractions . . . . . . . . . . . . . . . . . . . . 141

4.3 Nonreactive Atmosphere . . . . . . . . . . . . . . . . . 141

4.4 Hydrogen Pruduction . . . . . . . . . . . . . . . . . . . . . 142

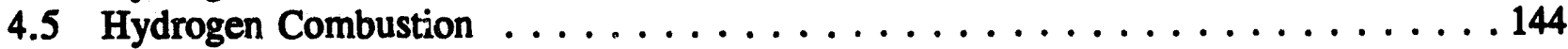

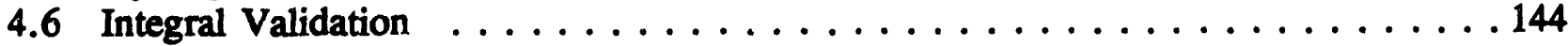

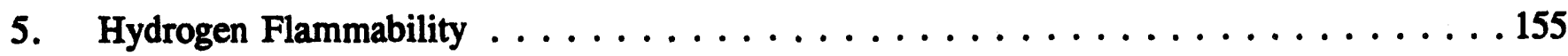

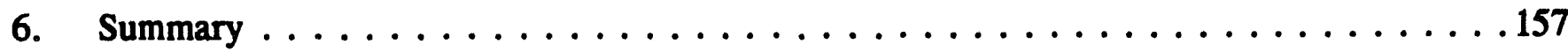

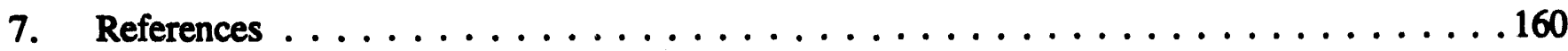

Appendix A: A Two-Cell Equilibrium Model for Predicting DCH . . . . . . . . . . . 162

A.1 Introduction . . . . . . . . . . . . . . . . . . . . . . . . 162

A.2 A Single-Cell Adiabatic Equilibrium Model . . . . . . . . . . . . . . . . 162

A.2.1 Molar Inventory of the Containment Atmosphere and the RCS . . . . . 165

A.2.2 Amount of Debris Participating in DCH . . . . . . . . . . . 166

A.2.3 Energy Source Resulting frorin RCS Blowdown . . . . . . . . . . . . 167

A.2.4 Energy Source from Debris Thermal Energy . . . . . . . . . . . . . 167

A.2.5 Energy Source from Debris Oxidation . . . . . . . . . . . . . . 167

A.2.6 Energy Source Resulting from Hydrogen Combustion . . . . . . . . . . . . 169

A.2.7 Material Properties . . . . . . . . . . . . . . . . 170

A.3 Two-Cell Adiabatic Equilibrium Model . . . . . . . . . . . . . . . . 170

A.3.1 DCH Processes in the Subcompartment $\ldots \ldots \ldots \ldots \ldots \ldots \ldots$

A.3.2 DCH Processes in the Dome . . . . . . . . . . . . . . . 174

A.3.3 Coherence of Blowdown Gas with Debris Dispersal . . . . . . . . . 175

A.3.4 Hydrogen Combustion in the Dome . . . . . . . . . . . . . . 175 


\section{Contents (concluded)}

Page

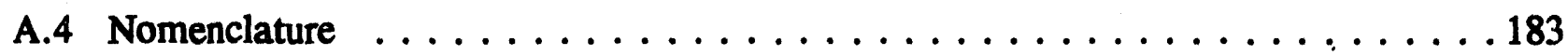

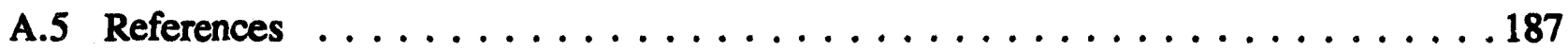




\section{Figures}

Figure

Page

2.1 Surtsey vessel, high-pressure melt ejection system, and subcompartment structures used in the IET experiments . . . . . . . . . . . . . . . . . 37

2.2 Melt generator and $\mathrm{MgO}$ crucible used in the IET experiments $\ldots \ldots \ldots \ldots \ldots$

2.3 Schematic of the $1: 10$ linear scale model of the Zion reactor cavity . . . . . . . . . . . 39

2.4 High-pressure steam boiler, steam accumulator, melt generator, cavity, and Surtsey vessel layout used in the IET experiments . . . . . . . . . . . . . . . . . . 40

2.5 Two-dimensional view of the subcompartment structures inside the

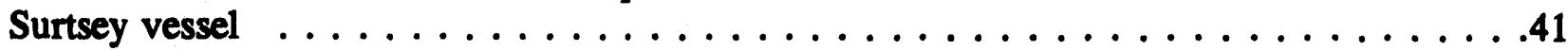

2.6 Isometric view of the subcompartment structures inside the

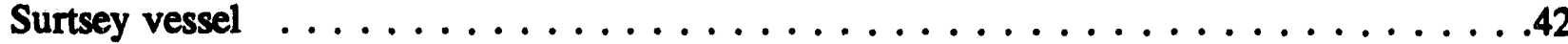

2.7 Top view of structures inside the Surtsey vessel . . . . . . . . . . . . . . . . . 43

2.8 Top view of the Surtsey vessel showing instrumentation ports . . . . . . . . . . . . . 44

2.9 Location of Surtsey vessel bulk gas temperature thermocouple arrays . . . . . . . . . . . 45

2.10 Composite view of the high-pressure steam boiler, steam accumulator, and burst diaphragm used in the IET-2 experiment . . . . . . . . . . . . . . . . . .46

2.11 Isometric view of the nondispersive cavity used in the IET-2 experiments . . . . . . . . . 47

2.12 End view of the melt generator and the nondispersive cavity used in the IET-2 experiments . . . . . . . . . . . . . . . . . . . . . . . . . . . . .

2.13 Side view of the melt generator and the nondispersive cavity used in the IET-2 experiments . . . . . . . . . . . . . . . . . . . . . . . . . . . . . . . . . . . . . .

3.1 Blowdown history of the IET-1 experiment $\ldots \ldots \ldots \ldots \ldots$

3.2 Blowdown history of the IET-1R experiment $\ldots \ldots \ldots \ldots \ldots \ldots \ldots$

3.3 Blowdown history of the IET-3 experiment $\ldots \ldots \ldots \ldots \ldots \ldots \ldots$

3.4 Blowdown history of the IET-4 experiment $\ldots \ldots \ldots \ldots \ldots \ldots \ldots$

3.5 Blowdown history of the IET-5 experiment $\ldots \ldots \ldots \ldots \ldots \ldots \ldots$

3.6 Blowdown history of the IET-6 experiment $\ldots \ldots \ldots \ldots \ldots \ldots \ldots$

3.7 Blowdown history of the IET-7 experiment $\ldots \ldots \ldots \ldots \ldots \ldots \ldots$

3.8 Blowdown history of the IET-8A experiment $\ldots \ldots \ldots \ldots \ldots$

3.9 Blowdown history of the IET-8B experiment . . . . . . . . . . . . . . . . . . 77

3.10 Blowdown pressure in the IET-1 experiment . . . . . . . . . . . . . . . . . . 78

3.11 Blowdown pressure in the IET-1R experiment . . . . . . . . . . . . . . . . . . . 79

3.12 Blowdown pressure in the IET-3 experiment . . . . . . . . . . . . . . . . . . . .80

3.13 Blowdown pressure in the IET-4 experiment . . . . . . . . . . . . . . . . . 81

3.14 Blowdown pressure in the IET-5 experiment . . . . . . . . . . . . . . . . . . . . 82

3.15 Blowdown pressure in the IET-6 experiment . . . . . . . . . . . . . . . . . 83

3.16 Blowdown pressure in the IET-7 experiment . . . . . . . . . . . . . . . . . . . 84

3.17 Blowdown pressure in the IET-8B experiment $\ldots \ldots \ldots \ldots \ldots \ldots$

3.18 Surtsey vessel pressure versus time in the IET-1 experiment . . . . . . . . . . . . 86

3.19 Surtsey vessel pressure versus time in the IET-1R experiment . . . . . . . . . . . . . 87

3.20 Surtsey vessel pressure versus time in the IET-3 experiment . . . . . . . . . . . . . . 88

3.21 Surtsey vessel pressure versus time in the IET-4 experiment . . . . . . . . . . . . . .89 


\section{Figures (continued)}

Figure

Page

3.22 Surtsey vessel pressure versus time in the IET-5 experiment . . . . . . . . . . . . 90

3.23 Surtsey vessel pressure versus time in the IET-6 experiment . . . . . . . . . . . . . .91

3.24 Surtsey vessel pressure versus time in the IET-7 experiment . . . . . . . . . . . . 92

3.25 Surtsey vessel pressure versus time in the IET-8A experiment . . . . . . . . . . . .93

3.26 Surtsey vessel pressure versus time in the IET-8B experiment . . . . . . . . . . . . . . . 94

3.27 Cavity pressure and Surtsey vessel pressure versus time in the

IET-1 experiment . . . . . . . . . . . . . . . . . . . .95

3.28 Cavity pressure and Surtsey vessel pressure versus time in the

IET-1R experiment . . . . . . . . . . . . . . . . . . . . . . . . . . . . . . . . . .

3.29 Cavity pressure and Surtsey vessel pressure versus time in the IET-3 experiment . . . . . . . . . . . . . . . . . . . . . . . .

3.30 Cavity pressure and Surtsey vessel pressure versus time in the

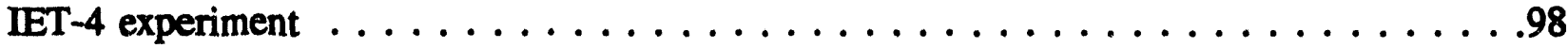

3.31 Cavity pressure and Surtsey vessel pressure versus time in the

IET-5 experiment . . . . . . . . . . . . . . . . . . . . . . . . . . . .99

3.32 Cavity pressure and Surtsey vessel pressure versus time in the

IET-6 experiment . . . . . . . . . . . . . . . . . . 100

3.33 Cavity pressure and Surtsey vessel pressure versus time in the

IET-7 experiment . . . . . . . . . . . . . . . . . . . . . . . 101

3.34 Cavity pressure and Surtsey vessel pressure versus time in the

IET-8A experiment . . . . . . . . . . . . . . . . . . . . 102

3.35 Cavity pressure and Surtsey vessel pressure versus time in the

IET-8B experiment . . . . . . . . . . . . . . . . . . . . . . . . . 103

3.36 Seal table room pressure and Surtsey vessel pressure versus time

in the IET-6 experiment . . . . . . . . . . . . . . . . . . . . . . . . . . . . . . 104

3.37 Seal table room differential pressure and debris ejection timing in

the IET-6 experiment . . . . . . . . . . . . . . . . . . . . . . . . . . . . . 105

3.38 Subcompartment absolute pressure compared to Surtsey vessel pressure

in the IET-6 experiment . . . . . . . . . . . . . . . . . . . . 106

3.39 Subcompartment differential pressure in the IET- 6 experiment . . . . . . . . . . . . 107

3.40 Thermite temperature measured from the west side of the melt generator exit

with the two-color pyrometer in the IET-2A experiment . . . . . . . . . . . . . 108

3.41 Thermite temperature measured from the west side of the melt generator exit

with the two-color pyrometer in the IET-2B experiment . . . . . . . . . . . . . . . . 109

3.42 Thermite temperature measured from the west side of the melt generator exit

with the two-color pyrometer in the IET-2C experiment . . . . . . . . . . . . . . 110

3.43 Thermite temperature measured from the east side of the melt generator exit

with a type $11 \times 30$ optical pyrometer in the IET-2A experiment $\ldots \ldots \ldots \ldots \ldots 11$

3.44 Thermite temperature measured from the east side of the melt generator exit

with a type $11 \times 30$ optical pyrometer in the IET-2B exptriment . . . . . . . . . . 112

3.45 Thermite temperature measured from the east side of the melt generator exit

with a type $11 \times 30$ optical pyrometer in the IET-2C experiment $\ldots \ldots \ldots \ldots \ldots$ 


\section{Figures (continued)}

3.46 Thermite temperature measured from the bottom of the melt generator with a type $11 \times 30$ optical pyrometer in the IET-2B experiment . . . . . 114

3.47 Thermite temperature measured from the bottom of the melt generator with a type $11 \times 30$ optical pyrometer in the IET-2C experiment . . . . . 115

3.48 Temperature history in the triangular vent space above RCP $1 \mathrm{~A}$ in the IET experiments . . . . . . . . . . . . . . . . . . . . 116

3.49 Gas temperatures measured in the upper dome of the Surtsey vessel with aspirated thermocouples in the IET-1 experiment . . . . . . . . . . . . . . . . 117

3.50 Gas temperatures measured in the upper dome of the Surtsey vessel with aspirated thermocouples in the IET-1R experiment . . . . . . . . . . . . 118

3.51 Gas temperatures measured in the upper dome of the Surtsey vessel with aspirated thermocouples in the IET-3 experiment . . . . . . . . . . . . . . . . . . 119

3.52 Gas temperatures measured in the upper dome of the Surtsey vessel with aspirated thermocouples in the IET-4 experiment . . . . . . . . . . . . . . . . . . 120

3.53 Gas temperatures measured in the upper dome of the Surtsey vessel with aspirated thermocouples in the IET-5 experiment . . . . . . . . . . . . . . 121

3.54 Gas temperatures measured in the upper dome of the Surtsey vessel with aspirated thermocouples in the IET-6 experiment . . . . . . . . . . . . . . . . . . 122

3.55 Gas temperatures measured in the upper dome of the Surtsey vessel with aspirated thermocouples in the IET-7 experiment . . . . . . . . . . . . . . . 123

3.56 Gas temperatures measured in the upper dome of the Surtsey vessel with aspirated thermocouples in the IET-8B experiment . . . . . . . . . . . . . . . . 124

3.57 Temperature histories of the thermocouple arrays in the IET experiments . . . . . . . 125

3.58 Relative pressure increase compared to the bulk gas temperature increase in the Surtsey vessel in the IET -4 experiment . . . . . . . . . . . . . . . . 126

3.59 Relative pressure increase compared to the bulk gas temperature increase in the Surtsey vessel in the IET-6 experiment . . . . . . . . . . . . . . . . . . . 127

3.60 Relative pressure increase compared to the bulk gas temperature increase in the Surtsey vessel in the IET-7 experiment . . . . . . . . . . . . . 128

3.61 Temperatures in the Surtsey upper dome at short times for the IET-7 experiment . . . . . . . . . . . . . . . . . . . . . . . . . . . . . . . 129

3.62 Temperatures in the Surtsey upper dome at long times after the IET-7 experiment . . . . . . . . . . . . . . . . . . . . 130

3.63 Upper dome gas temperatures for the IET-7 experiment . . . . . . . . . . . . 131

3.64 Relative pressure increase compared to the bulk gas temperature increase in the Surtsey vessel in the IET-8A experiment . . . . . . . . . . . . . . . . . 132

3.65 Relative pressure increase compared to the bulk gas temperature increase in the Surtsey vessel in the IET-8B experiment $\ldots \ldots \ldots \ldots \ldots \ldots \ldots \ldots \ldots$

3.66 Comparison of the oxygen concentrations measured in the IET experiments . . . . . . . 134

3.67 Comparison of the hydrogen concentrations measured in the IET experiments . . . . . 135

3.68 Comparison of the hydrogen combustion versus time in the IET experiments . . . . . . 136

3.69 Comparison of the hydrogen production versus time in the IET experiments . . . . . 137 


\section{Figures (concluded)}

Eiqure

3.70 Net difference between production and combustion of hydrogen versus time in the IET experiments . . . . . . . . . . . . . . . . . . . . . . 138

3.71 Posttest sieve analysis of debris recovered from outside the subcompartment structures in the Surtsey vessel in the IET-8B experiment . . . . . . . . . . . . . . . 139

4.1 Idealized blowdown curve and cavity pressure curve illustrating the method used to determine the coherence ratio . . . . . . . . . . . . . . . . . . . . . 147

4.2 Coherence of debris dispersal (entrainment) with blowdown gas . . . . . . . . . . 148

4.3 Distribution of melt mass in the Zion geometry . . . . . . . . . . . . . . . . . . . 149

4.4 Validation of the TCE model with experiments where the atmosphere was inert . . . . . . . . . . . . . . . . . . . . . . . . . . . 150

4.5 Validation of hydrogen production predictions (no cav $\% /$ containment water and nonreactive atmospheres) . . . . . . . . . . . . . . . . . . . . . . . . 151

4.6 Comparison of hydrogen production predictions with experiment data (water in cavity and/or containment and/or reactive atmospheres) . . . . . . . . . . 152

4.7 Validation of the TCE model with experiments where hydrogen could burn in a reactive atmosphere . . . . . . . . . . . . . . . . . . 153

4.8 Validation of the TCE model against all experiments with compartmentalized geometry . . . . . . . . . . . . . . . . . . . . . . . . 154

5.1 Upward propagation limit for hydrogen/oxygen/nitrogen mixtures $\ldots \ldots \ldots \ldots \ldots \ldots$ 


\section{Tables}

Table

Pare

1.1 Survey of DCH relevant experiments $\ldots \ldots \ldots \ldots \ldots \ldots \ldots \ldots \ldots$

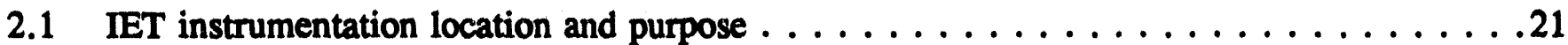

2.2 Target conditions for counterpart experiments as designed . . . . . . . . . . . 29

2.3 Geometric parameters for counterpart experiments as designed . . . . . . . . . . 30

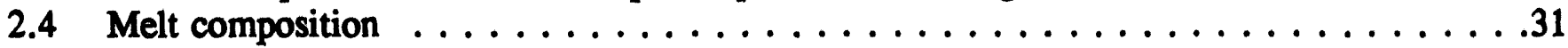

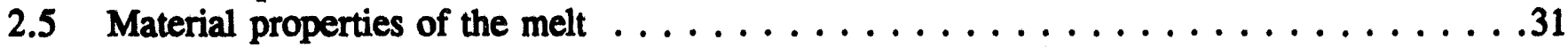

2.6 Equilibrium models for estimating containment pressurization $\ldots \ldots \ldots \ldots \ldots \ldots 32$

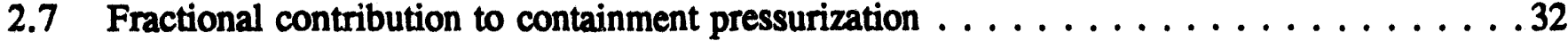

2.8 Atmosphere composition for Zion containment $\ldots \ldots \ldots \ldots \ldots \ldots \ldots \ldots \ldots \ldots \ldots$

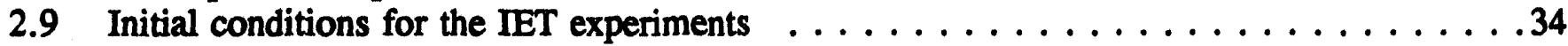

2.10 Initial conditions for the IET-2A, IET-2B, and IET-2C experiments $\ldots \ldots \ldots \ldots \ldots 35$

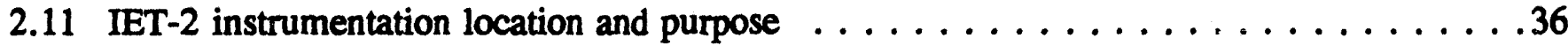

3.1 Summary of the results of the IET-2A, IET-2B, and IET-2C experiments . . . . . . . 64

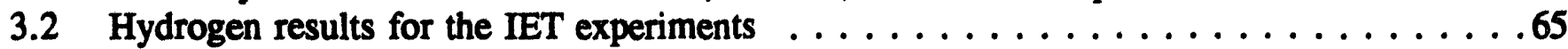

3.3 Debris recovery summary for the IET experiments $\ldots \ldots \ldots \ldots \ldots \ldots \ldots \ldots 6$

3.4 Sieve mass median diameter for the IET experiments $\ldots \ldots \ldots \ldots \ldots \ldots \ldots \ldots$

3.5 Energy balance for the IET experiments $\ldots \ldots \ldots \ldots \ldots \ldots \ldots \ldots \ldots \ldots \ldots$

4.1 Computed values of the coherence ratio . . . . . . . . . . . . . . 145

4.2 Time variations of reported hydrogen measurements $\ldots \ldots \ldots \ldots \ldots \ldots \ldots \ldots$

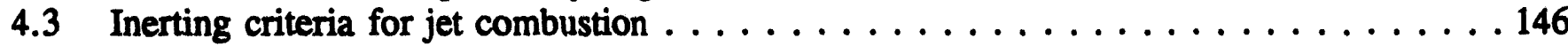

4.4 Validation of autoignition criteria for volumetric combustion . . . . . . . . . . 146

6.1 Summary of the results of the IET experiments $\ldots \ldots \ldots \ldots \ldots \ldots \ldots \ldots$

A.1 Specific molar properties of debris $\ldots \ldots \ldots \ldots \ldots \ldots \ldots \ldots \ldots \ldots \ldots$

A.2 Specific molar heat capacity of containment atmosphere $\ldots \ldots \ldots \ldots \ldots \ldots \ldots \ldots 1$

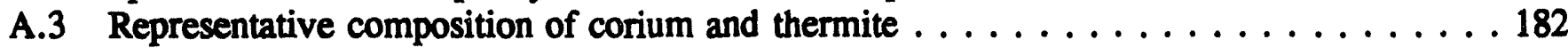

A.4 Representative composition of a containment atmosphere $\ldots \ldots \ldots \ldots \ldots \ldots \ldots$ 


\section{Executive Summary}

In a light water reactor core-melt accident, an instrument guide tube penetration in the bottom head of the reactor pressure vessel (RPV) may fail while the primary system is pressurized. The aperture formed in the RPV by a penetration type failure can ablate to a diameter of 30 to $40 \mathrm{~cm}$ as molten core debris is expelled into the reactor cavity. The blowdown of the reactor coolant system (RCS) may then entrain molten core debris in the high-velocity steam blowdown gas and eject fragmented particles from the cavity into the reactor containment building (RCB). This chain of events is called a high-pressure melt ejection (HPME). As the fragmented, molten debris is dispersed into the RCB, three mechanisms may cause a rapid increase in pressure and temperature: (1) efficient debris-to-gas heat transfer, (2) exothermic metal/oxygen reactions, and (3) hydrogen combustion. The processes that lead to increased loads on the containment building are collectively referred to as direct containment heating (DCi1). Understanding factors that enhance or mitigate DCH is necessary because the load imposed on the RCB may potentially threaten its integrity.

The Surtsey Test Facility at Sandia National Laboratories (SNL) is used to perform scaled experiments for the Nuclear Regulatory Commission (NRC) that simulate a HPME accident in a nuclear power plant (NPP). The experiments are designed to investigate the phenomena associated with DCH. High-temperature, chemically reactive melt is ejected from a melt generator by high-pressure steam into a 1:10 linear scale model of a reactor cavity. Debris is entrained by the steam blowdown into the Surtsey test vessel. The effects of specific phenomena on the containment load, such as the geometry of subcompartment structures, water in the cavity and on the containment basement floor, and hydrogen generation and combustion, are studied.

The Integral Effects Test (IET) series was conducted using 1:10 linear scale models of the Zion NPP structures. There were twelve experiments in the IET test series: IET-1, IET-1R, IET-2A, IET-2B, IET-2C, IET-3, IET-4, IET-5, IET-6, IET-7, IET-8A, and IET-8B. In the IET-2A, 2B, and 2C experiments, the Surtsey vessel was not used; the melt generator was attached to a nondispersive cavity. These tests were conducted specifically to determine the temperature of debris ejected from the scaled RPV model into the reactor cavity. The other experiments used models of the Zion structures, including the bottom head of the RPV, biological shield wall, reactor cavity, instrument tunnel, containment basement floor, seal table room, refueling canal, steam generators, reactor coolant pumps (RCPs), and operating deck. The Surtsey vessel was used to simulate the upper dome of the Zion RCB.

Specific phenomena investigated in the IET test series were (1) the effect of physical scale, (2) the effect of prototypic subcompartment structures, (3) the effect of water in the cavity and on the containment basement floor, and (4) the effect of hydrogen combustion on containment loads. Generally, these experiments were performed in a systematic manner by changing one major parameter for each test. However, it is difficult to compare similar experiments without a normalizing tool because of random variations in the initial conditions and stochastic variations in the experimental results. The two-cell equilibrium (TCE) model, which is developed in Appendix A, was used to account for these variations so that observations of a more general nature could be made about specific phenomena observed in the IET test series. 


\section{Executive Summary}

Extrapolating experimental results to a full-scale NPP accident is an issue that has been addressed by the Severe Accident Scaling Methodology (SASM) Technical Program Group and by Pilch and Allen. ${ }^{1}$ These efforts led the NRC to sponsor counterpart experiments by SNL at 1:10 linear scale and by Argonne National Laboratory (ANL) at 1:40 linear scale. The IET experiments conducted by SNL and ANL, and a large number of other DCH experiments, were analyzed with the TCE model. The conclusion was drawn that there is no clear effect of physical scale.

The major structures of the Zion NPP were car fully modeled for the SNL and ANL IET experiments. However, it was concluded that the loads were not very sensitive to the specific details of the subcompartment geometry. This conclusion is based on the fact that the TCE model shows good agreement for the entire DCH database, even for experiments having very simplified representations of structures. However, containment loads are dependent on any direct flow paths from the cavity to the upper dome, such as the annular gap between the RPV and reactor support skirt.

Condensate levels of water were present on the scaled reactor cavity floor in the majority of the IET tests. From previous tests, it was concluded that condensate levels of water had very little effect on the containment load. In two of the IET tests (IET-8A and IET-8B), the cavity was half full of water. There were apparently competing effects on the containment load: cavity and subcompartment water quenched the debris and thus reduced debris/gas heat transfer, and at the same time, vaporization of cavity and subcompartment water produced many moles of steam, which caused an increase in the pressure load in the vessel, i.e., a steam spike. In addition, some hydrogen buined as a diffusion flame as it was ejected from the subcompartment structures into the upper dome. The effects of debris quenching and of production of steam and some hydrogen apparently balanced each other and resulted in no noticeable effect on the containment load for the specific conditions studied.

In the IET experiments, the Surtsey ressel atmosphere was either inert or reactive. In IET-1 and IET-1R, the Surtsey atmosphere was inerted by purging with nitrogen $\left(<0.1 \mathrm{~mol} . \% \mathrm{O}_{2}\right)$. The IET-5 experiment was "classically" inerted with carbon dioxide, which was used as a surrogate for steam. In all of the other IET experiments, the Surtsey atmosphere was reactive, i.e., about 9 mol.\% $\mathrm{O}_{2}$. In IET-5, IET-6, IET-7, IET-8A, and IET-8B, the Surtsey atmosphere also contained preexisting hydrogen. The preexisting hydrogen represented levels produced by partial clad oxidation during the core degradation process in a NPP pump seal loss-of-coolant accident. In the IET experiments, hydrogen produced by reactions between the blowdown steam and metallic debris burned as it was ejected from the subcompartment structures and contributed significantly to the containment load. However, the preexisting hydrogen recombined on a time scale too long to have a significant impact on the containment load.

\footnotetext{
' M.M. Pilch and M.D. Allen, Dec. 1990, A Scaling Methodology for Direct Containment Heating with Application to the Desion and Specification of an Experiment Program for Resolving DCH Issues, SAND91-2784, to be published, Sandia National Laboratories, Albuquerque, NM.
} 


\section{Acknowledgments}

The authors express their gratitude to Michael Oliver, who was the electronics and instrumentation engineer for these experiments, and to James Ross, Tim Covert, and Robert Carolan, who were the mechanical technicians. The authors appreciate the technical review of this report provided by Dr. T.Y. Chu and Dr. Ed Parma.

This work was funded by the Accident Evaluation Branch of the United States Nuclear Regulatory Commission. 


\subsection{Introduction}

In a light water reactor core-melt accident, an instrument guide tube penetration in the bottom head of the reactor pressure vessel (RPV) may fail while the primary system is pressurized. The aperture formed in the RPV by a penetration type failure can ablate to a diameter of 30 to $40 \mathrm{~cm}$ as molten core debris is expelled into the reactor cavity. The blowdown of the reactor coolant system (RCS) may then entrain molten core debris in the high-velocity steam blowdown gas and eject fragmented particles from the cavity into the reactor containment building (RCB). This chain of events is called a high-pressure melt ejection (HPME). As the fragmented, molten debris is dispersed into the RCB, three mechanisms may cause a rapid increase in pressure and temperature: (1) efficient debris-togas rizat transfer, (2) exothermic metal/oxygen reactions, and (3) hydrogen combustion. These processes that lead to increased loads on the containment building are collectively referred to as direct containment heating (DCH). Understanding factors that enhance or mitigate $\mathrm{DCH}$ is necessary because the load imposed on the RCB may potentially threaten its integrity.

DCH experiments have been previously conducted at Sandia National Laboratories (SNL), Argonne National Laboratory (ANL), and Fauske and Associates (FAI). Of interest here are experiments employing high-temperature chemically reactive melts, driven under pressure into a simulated reactor cavity, with the whole system confined in a vessel so that containment pressure can be measured. A brief survey of these experiments, including experiments conducted after the Zion Integral Effects Test (IET) were completed, is presented in Table 1.1. (All tables and figures are located at the end of the chapter in which they are referenced.) Experiments have been conducted at four different physical scales; in two different cavity designs; and with and without subcompartment structures, reactive and nonreactive blowdown gases, and reactive and nonreactive containment atmospheres.
The earliest DCH tests were the ANL/CWTI tests (1:30 scale), which showed significant mitigation of loads resulting from a combination of plant specific subcompartment structures and cavity water. Some researchers felt that the observed containment pressurizations were substantially lower than would be expected at full scale because the time scale for heat and mass transfer is compressed in small scale experiments.

The early Sandia experiments (SNL/DCH, SNL/TDS, SNL/WC) were conducted at much larger scale $(1: 10)$ and without any attempt to simulate the compartmentalized nature of real containments. In this way, separate effects information on heat and mass transfer rates, debris velocity, and other phenomena could be obtained for development of the CONTAIN code. The effect of containment compartmentalization was crudely simulated in the SNL/LFP test series by placing a simple concrete slab at an adjustable height above the cavity exit. Henry et al. [1991] also conducted DCH experiments (FAI/DCH) that included simulations of Zion subcompartment structures. These experiments produced DCH loads significantly less than would be predicted by simple bounding models. However, questions persisted on the effects of physical scale.

These early experiments were reviewed as part of an NRC sponsored effort known as the Severe Accident Scaling Methodology (SASM) Program [Zuber et al. 1991]. As a result of SASM recommendations, the NRC sponsored experiment programs were redirected towards performing counterpart experiments (SNL/IET and ANL/ IET) at two different physical scales, including detailed (geometrically scaled) simulations of the Zion subcompartment structures, and with initial conditions closely tied to postulated and likely accident scenarios. This report documents the SNL/IET experiments; their smaller scale counterparts (ANL/IET) were conducted at Argonne National Laboratory. The SNL/ANL 
counterpart experiments are also summarized in Table 1.1 for completeness.

Guidance for the experiment programs was assigned by the NRC to a five-member $\mathrm{DCH}$ Experiment Technical Review Group (TRG), who were all members of the original SASM program and included R.E. Henry (FAI), M. Ishii (Purdue), F.J. Moody (GE), B.R. Sehgal (EPRI), and T.G. Theofanous (UCSB). The DCH "team," consisting of the sponsor (NRC), universities and industry (TRG), and the national laboratories (SNL and ANL), meets at periodic intervals to discuss new results and decide future directions. Despite diverse backgrounds, the team worked efficiently to reach a consensus so that the pace of the program was limited only by time necessary to prepare and execute the experiments.

The IET series was conducted using 1:10 linear scale models of the Zion NPP structures. There were twelve experiments in the IET test series: IET-1, IET-1R, IET-2A, IET-2B, IET-2C, IET-3, IET-4, IET-5, IET-6, IET-7, IET-8A, and IET-8B. In the IET-2A, 2B, and 2C experiments, the Surtsey vessel was not used; the melt generator was attached to a nondispersive cavity. These tests were conducted specifically to determine the temperature of debris ejected from the scaled RPV model into the reactor cavity. The other experiments used models of the Zion structures, including the bottom head of the RPV, biological shield wall, reactor cavity, instrument tunnel, containment basement floor, seal table room, refueling canal, steam generators, reactor coolant pumps (RCPs), and operating deck. The Surtsey vessel was used to simulate the upper dome of the Zion RCB.

Condensate levels of water were present on the scaled reactor cavity floor in the majority of the
IET tests. Previous tests [Allen et al. 1992a] showed that condensate levels of water had very little effect on the containment load. In two of the IET tests (IET-8A and IET-8B), the cavity was half full of water. Water was also present on the containment basement floor inside the crane wall for most of these tests.

In the IET experiments, the Surtsey vessel atmosphere was either inert or reactive. In IET-1 and IET-1R, the Surtsey atmosphere was inerted by purging with nitrogen $\left(<0.1 \mathrm{~mol} . \% \mathrm{O}_{2}\right)$. The IET-5 experiment was "classically" inerted with carbon dioxide, which was used as a surrogate for steam. In all of the other IET experiments, the Surtsey atmosphere was reactive, i.e., about 9 mol. \% $\mathrm{O}_{2}$. In IET-5, IET-6, IET-7, IET-8A, and IET-8B, the Surtsey atmosphere also contained preexisting hydrogen. The preexisting hydrogen represented levels produced by partial clad oxidation during the core degradation process in a NPP pump seal loss-of-coolant accident.

Specific phenomena investigated in the IET test series were (1) the effect of physical scale, (2) the effect of prototypic subcompartment structures, (3) the effect of water in the cavity and on the containment basement floor, and (4) the effect of hydrogen combustion on containment loads. Generally, these experiments were performed in a systematic manner by changing one major parameter for each test. However, it is difficult to compare similar experiments without a normalizing tool because of random variations in the initial conditions and stochastic variations in the experimental results. The two-cell equilibrium (TCE) model, which is developed in Appendix $A$, was used to account for these variations so that conclusions could be drawn about specific phenomena observed in the IET test series. 
Table 1.1 Survey of DCH relevant experiments

\begin{tabular}{|c|c|c|c|c|}
\hline Experiment series & $\begin{array}{l}\text { Number } \\
\text { of tests }\end{array}$ & $\begin{array}{l}\text { Nominal } \\
\text { scale }\end{array}$ & $\begin{array}{l}\text { Cavity } \\
\text { type }\end{array}$ & Water. \\
\hline $\begin{array}{c}\text { SNL/DCH } \\
\text { Tarbell et al. [1987; 1988] } \\
\text { Allen et al. [1991a] }\end{array}$ & 4 & $1: 10$ & Zion & None \\
\hline SNL/TDS & 7 & $1: 10$ & Surry & None \\
\hline $\begin{array}{c}\text { SNL/LFP } \\
\text { Allen et al. [1991b] }\end{array}$ & 6 & $1: 10$ & Surry & None \\
\hline $\begin{array}{c}\text { SNL/WC } \\
\text { Allen et al. }[1992 a, b]\end{array}$ & 3 & $1: 10$ & Zion & $\begin{array}{l}\text { None } \\
\text { Cavity }\end{array}$ \\
\hline $\begin{array}{l}\text { SNL/IET-Zion } \\
\text { Allen et al. } \\
\text { [1992c-h, 1993] }\end{array}$ & 9 & $1: 10$ & Zion & $\begin{array}{c}\text { Cavity } \\
\text { Cavity/Basement }\end{array}$ \\
\hline SNL/IET-Surry & 3 & $1: 5.75$ & Surry & $\begin{array}{c}\text { None } \\
\text { Cavity/Basement }\end{array}$ \\
\hline $\begin{array}{c}\text { ANL/CWTI } \\
\text { Spencer et al. }[1987]\end{array}$ & 2 & $1: 30$ & Zion-like & Cavity/Basement \\
\hline $\begin{array}{c}\text { ANL/IET } \\
\text { Binder et al. [1992a-f] }\end{array}$ & 6 & $1: 40$ & Zion & $\begin{array}{l}\text { None } \\
\text { Cavity }\end{array}$ \\
\hline $\begin{array}{l}\text { ANL/U } \\
\text { Binder et al. } \\
\text { [1993a, b] }\end{array}$ & 3 & $1: 40$ & Zion & None \\
\hline $\begin{array}{c}\text { FAI/DCH } \\
\text { Henry et al. }[1991]\end{array}$ & 4 & $1: 20$ & Zion & $\begin{array}{c}\text { Basement/ } \\
\text { Cavity/Basement }\end{array}$ \\
\hline
\end{tabular}


Introduction

Table 1.1 Survey of DCH relevant experiments (continued)

\begin{tabular}{|c|c|c|c|c|}
\hline $\begin{array}{l}\text { Experiment } \\
\text { series }\end{array}$ & $\begin{array}{c}\text { Containmen } \\
\text { t } \\
\text { pressure } \\
\text { (MPa) }\end{array}$ & $\begin{array}{l}\text { Annular gap } \\
\text { around } \\
\text { RPV }\end{array}$ & $\begin{array}{l}\text { Atmosphere } \\
\text { composition }\end{array}$ & $\begin{array}{l}\text { Containment } \\
\text { structures }\end{array}$ \\
\hline SNL/DCH & 0.08 & No & Air, Ar & Open Containment \\
\hline SNL/TDS & $0.09-0.23$ & No & Air, Ar & Open Containment \\
\hline SNL/LFP & 0.16 & No & Ar & Compartmentalized by Slab \\
\hline SNL/WC & 0.16 & No & Ar & Essentially Open \\
\hline $\begin{array}{l}\text { SNL/IET } \\
\text { Zion }\end{array}$ & 0.2 & No & $\begin{array}{l}\mathrm{N}_{2}, \mathrm{~N}_{2} / \mathrm{Air} \\
\mathrm{N}_{2} / \mathrm{Air} / \mathrm{H}_{2}, \\
\mathrm{CO}_{2} / \mathrm{Air} / \mathrm{H}_{2}\end{array}$ & $\begin{array}{c}\text { Zion } \\
\text { Subcompartment } \\
\text { Structures }\end{array}$ \\
\hline $\begin{array}{l}\text { SNL/IET } \\
\text { Surry }\end{array}$ & $0.13-0.19$ & $\begin{array}{l}\text { No partial } \\
\text { insulation }\end{array}$ & $\mathrm{Air} / \mathrm{H}_{2} \mathrm{O} / \mathrm{H}_{2}$ & $\begin{array}{c}\text { Surry } \\
\text { Subcompartment } \\
\text { Structures }\end{array}$ \\
\hline ANL/CWTI & 0.1 & No & $\mathbf{A r}$ & $\begin{array}{c}\text { Compartmentalized by } \\
\text { Baffle }\end{array}$ \\
\hline ANL/IET & 0.2 & No & $\begin{array}{c}\mathrm{N}_{2}, \mathrm{~N}_{2} / \mathrm{Air}, \\
\mathrm{N}_{2} / \mathrm{Air} / \mathrm{H}_{2}, \\
\mathrm{H}_{2} \mathrm{O} / \mathrm{Air} / \mathrm{H}_{2}\end{array}$ & $\begin{array}{c}\text { Zion } \\
\text { Subcompartment } \\
\text { Structures }\end{array}$ \\
\hline ANL/U & 0.2 & No & $\mathrm{N}_{2} / \mathrm{Air} / \mathrm{H}_{2}$ & $\begin{array}{c}\text { Zion } \\
\text { Subcompartment } \\
\text { Structures }\end{array}$ \\
\hline FAI/DCH & 0.1 & No & $\mathbf{N}_{2}$ & $\begin{array}{c}\text { Zion (Like) } \\
\text { Subcompartment } \\
\text { Structures }\end{array}$ \\
\hline
\end{tabular}


Table 1.1 Survey of DCH relevant experiments (concluded)

\begin{tabular}{cccccc}
\hline $\begin{array}{c}\text { Experiment } \\
\text { series }\end{array}$ & $\begin{array}{c}\text { Driving } \\
\text { gas }\end{array}$ & $\begin{array}{c}\text { Driving } \\
\text { pressure } \\
(\mathrm{MPa})\end{array}$ & $\begin{array}{c}\text { Melt mass } \\
(\mathrm{kg})\end{array}$ & $\begin{array}{c}\text { Melt } \\
\text { composition }\end{array}$ & $\begin{array}{c}\text { Hole } \\
\text { size }\end{array}$ \\
\hline SNL/DCH & $\mathrm{N}_{2}$ & $2.6-6.7$ & 20,80 & $\mathrm{Fe} / \mathrm{Al}_{2} \mathrm{O}_{3}$ & 0.06 \\
SNL/TDS & $\mathrm{H}_{2} \mathrm{O}$ & $3.7-4.0$ & 80 & $\mathrm{Fe} / \mathrm{Al}_{2} \mathrm{O}_{3} / \mathrm{Cr}$ & 0.065 \\
SNL/LFP & $\mathrm{H}_{2} \mathrm{O}$ & $2.5-3.6$ & 50,80 & $\mathrm{Fe} / \mathrm{Al}_{2} \mathrm{O}_{3} / \mathrm{Cr}$ & $0.04-0.09$ \\
SNL/WC & $\mathrm{H}_{2} \mathrm{O}$ & $3.8-4.6$ & 50 & $\mathrm{Fe} / \mathrm{Al}_{2} \mathrm{O}_{3} / \mathrm{Cr}$ & $0.04-0.10$ \\
SNL/IET & $\mathrm{H}_{2} \mathrm{O}$ & $5.9-7.1$ & 43 & $\mathrm{Fe} / \mathrm{Al}_{2} \mathrm{O}_{3} / \mathrm{Cr}$ & 0.04 \\
Zion & & & & & \\
SNL/IET & $\mathrm{H}_{2} \mathrm{O}$ & 12 & 158 & $\mathrm{Fe} / \mathrm{Al}_{2} \mathrm{O}_{3} / \mathrm{Cr}$ & $0.072-0.098$ \\
Surry & & & & & \\
ANL/CWTI & $\mathrm{N}_{2}$ & $4.7-5.0$ & 4.1 & $\mathrm{UO}_{2} / \mathrm{ZrO}_{2} / \mathrm{SS}$ & 0.13 \\
ANL/IET & $\mathrm{H}_{2} \mathrm{O}$ & $5.7-6.7$ & $0.72,0.82$ & $\mathrm{Fe} / \mathrm{Al}_{2} \mathrm{O}_{3} / \mathrm{Cr}$ & 0.011 \\
ANL/U & $\mathrm{H}_{2} \mathrm{O}$ & $3.0-6.0$ & 1.13 & $\mathrm{UO}_{2} / \mathrm{Zr}_{\mathrm{ZrO}} / \mathrm{SS}$ & 0.011 \\
FAI/DCH & $\mathrm{N}_{2}$, & $2.4-3.2$ & 20 & $\mathrm{Fe} / \mathrm{Al}_{2} \mathrm{O}_{3}$ & 0.025 \\
\hline & $\mathrm{H}_{2} \mathrm{O}$ & & & & \\
\hline
\end{tabular}




\subsection{Experiment Description}

Figure 2.1 is a composite view of the Surtsey vessel, the HPME delivery system, and the subcompartment structures used in the IET experiments. The Surtsey vessel is an ASMEapproved steel pressure vessel with an internal volume of $103 \mathrm{~m}^{3}$, which makes it slightly overscaled (for a 1:10 linear scale) compared to most nuclear RCBs. It has a cylindrical shape with removable, dished heads attached to both ends and is $3.6 \mathrm{~m}$ in diameter by $10.3 \mathrm{~m}$ high. The Surtsey vessel has a maximum allowable working pressure of $1 \mathrm{MPa}$ at $260^{\circ} \mathrm{C}$, but has a burst diaphragm installed to limit the pressure in the vessel to less than $0.9 \mathrm{MPa}$. It is supported approximately $2 \mathrm{~m}$ off the ground by a structural steel framework with its longitudinal axis oriented vertically. The interior of the vessel has four equally spaced I-beams welded vertically along the length of the body of the vessel. Structural steel has been welded to these I-beams for adding removable scaffolding to facilitate instrumenting and cleaning the vessel. The internal steel framework also supports an overhead bridge crane to facilitate loading and unloading equipment. A total of twenty $30.5 \mathrm{~cm}$ (12 inch) and $61 \mathrm{~cm}$ (24 inch) instrument penetration ports exist at six different levels around the perimeter of the vessel. The Surtsey vessel has two manways at level 1 to allow personnel access. For the IET experiments, a concrete floor was constructed in Surtsey near the bottom of the vessel to simulate the containment basement floor in the Zion NPP. The freeboard volume above the floor was $89.8 \mathrm{~m}^{3}$.

Table 2.1 is a listing of the instrumentation used in the IET experiments, including the channel number, type, purpose, and location of each instrument. The circled numbers in Figures 2.1 through 2.9 correspond to the channel $n$.mbers in the data acquisition system listed in Table 2.1. Instrumentation changed slightly as the IET experiments progressed. Table 2.1 and the associated figures list the instruments used in the last few IET experiments.
The Surtsey IET tests [Allen et al. 1992c,d,e,f,g,h; 1993] were conducted with 1:10 linear scale models of the primary structures in the Zion NPP, including the bottom head of the RPV, cavity, in-core instrument tunnel, and subcompartment structures. The RPV was modeled with a melt generator that consisted of a steel pressure barrier, a cast $\mathrm{MgO}$ crucible, and a thin steel inner liner (Figure 2.2). The melt generator/crucible had a hemispherical bottom head containing a graphite limiter plate with a $3.5-\mathrm{cm}$ exit hole to simulate the ablated hole in the RPV bottom head that would be formed by ejection of an instrument guide tube and hole ablation in a severe NPP accident.

The cavity (Figure 2.3) used in the IET tests was designed to withstand internal pressures of 6.9 $\mathrm{MPa}$ with a safety factor of 4 . The inclined portion of the instrument tunnel entered the bottom head of Surtsey at a 26-degree angle from vertical, as it does in Zion. The instrument guide tubes were not modeled in the IET experiments. A false concrete floor was constructed in the Surtsey vessel similar to the floor of the Zion basement so that the inclined portion of the instrument tunnel was about 2.7 times the correct scaled length of the Zion instrument tunnel exit.

This floor and instrument tunnel were constructed in Surtsey to match the configuration of the ANL COREXIT $^{2}$ facility. Figure 2.4 shows the experiment configuration, including the highpressure steam boiler, accumulator tank, burst diaphragm, melt generator, cavity, and instrument tunnel connection to the Surtsey vessel.

The subcompartment structures included 1:10 linear scale models of the crane wall, four steam

\footnotetext{
2 J.L. Binder, et al., 1992, Quick Look Data Report on the Internal Effects Test 2 in the Corexit Facility at Arronne National Laboratory, Argonne National Laboratory, Argonne, IL.
} 
generators, four RCPs, the opening in the floor of the seal table room for the instrument guide tubes, the seal table room, the biological shield wall, the refueling canal, the radial beams and the gratings at the RCP deck, and the operating deck (Figures 2.5, 2.6, and 2.7). The steam generators, RCPs, and gratings were made of steel, and the other structures were constructed of reinforced concrete. All of the structures were painted with an epoxy-base paint. Figure 2.8 gives the top view of the Surtsey vessel, showing the orientation and location of the instrument penetrations through the vessel ports at six different levels.

In most of the experiments, the steam accumulator tanik (volume $=0.29 \mathrm{~m}^{3}$ ) was pressurized to $\approx 6.3 \mathrm{MPa}$ with superheated steam. After the pressurization sequence, the iron oxide/alumint $\mathrm{m} / \mathrm{chromium}$ thermite mixture was ignited remotely with a braided wire fuse placed on top of the compacted thermite. After the thermite was ignited, the pressure in the crucible (free volume $=0.018 \mathrm{~m}^{3}$ ) rapidly increased. This pressure increase verified that the thermite reaction had started and signaled the operator to fail the burst diaphragm separating the steam accumulator tank and the molten thermite in the melt generator. This brought superheated steam into contact with the molten thermite. Upon contacting and failing a fusible brass plug at the bottom of the crucible, the molten thermite in the crucible was expelled by high-pressure steam into the cavity.

In the IET-8A experiment, the burst diaphragm did not fail, and thus, the melt simulant was not ejected by high-pressure steam; it was drained from the cavity, primarily under the force of gravity. The iron oxide/aluminum/chromium thermite mixture was ignited remotely with a braided wire fuse placed on top of the compacted thermite. After the thermite was ignited, the nitrogen cover gas pressurized. Upon contacting and failing a fusible brass plug at the bottom of the crucible, the molten thermite in the crucible drained into the reactor cavity model, which was half-filled with water.

Zero time was set by the data acquisition system as the time at which the melt failed the brass plug and entered the cavity. This event was signaled by a photodiode located at the melt plug exit. When the hot melt burst through the brass plug, the intense light emitted from the melt caused the photodiode to emit a signal that was used to mark the initiation of the event.

\subsection{Geometry and Initial Conditions: The Design Basis}

The geometry and initial conditions selected for the SNL/IET experiments were guided by the pump seal LOCA sequence initiated by a station blackout in the Zion NPP. The stated goal was to perform integral effects tests in geometrically scaled structures with initial conditions generally (but not always) selected to be well within the expected range of full-scale plant behavior.

Table 2.2 lists the key (target) conditions for the tests along with the representative full-scale reactor conditions. The following sections discuss the rationale and potential compromises in selecting these conditions.

\subsubsection{Facility Geometry}

A stated goal was to perform counterpart experiments at two different physical scales with geometrically scaled mockups of the Zion plant. The counterpart experiments were conducted at SNL (1:10 scale) and at ANL (1:40 scale) so that maximum advantage could be taken of already existing facilities for performing DCH experiments. Hardware constraints, however, at either the SNL facility or the ANL facility required some compromise in the extent to which the experiment facilities could match Zion. As a priority, similarity between the SNL and ANL facilities was sought, even if it meant sacrificing some similarity with the full-scale plant. 
Table 2.3 compares some of the key geometric features in the SNL/IET experiments with their full-scale values so that deviations can be noted. The rationale for any deviations and their expected impact on the test results are discussed next.

The entire RCS is not geometrically scaled in the experiments. The SASM effort concluded that it was adequate to match the RCS free volume and geometrically scale the hemispherical lower head. SNL had an existing steam accumulator that was $14 \%$ underscaled (by volume) relative to Zion. Furthermore, the radius of the hemispherical melt generator in the experiments is $8 \%$ underscaled relative to Zion. This facilitated the more economical use of the off-the-shelf hemispherical heads. Both of these deviations were judged acceptable to the TRG.

The hole diameter plays a key role in determining the rate of RCS blowdown, which in turn controls the rate and magnitude of melt dispersal from the cavity. The scenario considered here is a penetration-type failure of the lower head. Such a failure could occur by the ejection of an incore instrument guide from the lower head or by melt flow into the guide tube causing the tube to rupture outside the lower head. The initial size of such a failure is $-0.025 \mathrm{~m}$, but melt flow through the hole will cause it to ablate to a much larger size.

A final hole size of $\sim 0.35 \mathrm{~m}$ is computed with the approximate ablation model given in Pilch and Allen. ${ }^{3}$ The calculation was carried out using the melt mass (scaled to Zion, i.e., $53 \mathrm{mt}$ ), and composition specified in the SASM document [Zuber et al. 1991].

\footnotetext{
${ }^{3}$ M.M. Pilch and M.D. Allen, Dec. 1990, A Scaling Methodology for Direct Contrinment Heating with Application to the Desion and Specification of an Experiment Prorrem for Resolvine DCH Issues, SAND91-2784, to be published, Sandia National Laboratories, Albuquerque, NM.
}

The ablation process could not be reliably simulated in the experiments because the initial hole size would have to be $\sim 2.5 \mathrm{~mm}$ in the SNL tests causing an unprototypic tendency for the melt to freeze in the hole. This problem would only be compounded in the smaller scale counterpart test at ANL. Consequently, it was decided to scale the initial hole size in the experiment to the final hole size predicted in the reactor case. Ablation was then suppressed in the experiment using a graphite plate (with the proper hole size) that would not erode. This procedure ensured that a properly scaled hole size was available for the blowdown process.

The reactor cavity in the experiment was geometrically scaled to the full-scale Zion configuration, with one notable exception. The chute extending from the cavity is 2.7 times longer than scaling would dictate. The reason for this deviation is twofold: (1) existing hardware at the SNL facility dictated that the accumulator, melt generator, and cavity assemblies be placed outside the containment vessel, and (2) the melt generator at the ANL facility would not fit under their containment vessel without extending the cavity chute. This distortion in the length of the cavity chute also leads to a $29 \%$ distortion in the total cavity volume, although the flow area scaling could be preserved. The TRG agreed that it was preferable to maintain similarity between the SNL/ANL counterpart facilities rather than match Zion exactly.

The TRG also agreed that these distortions were conservative in the sense that they likely would enhance cavity interactions and DCH loads. This follows from an analysis by Henry et al. [1991], which showed that the relative contribution of entrainment (small particles) and displacement (films) to the dispersal process is preserved when the cavity is geometrically scaled. As-built distortions in the chute length would result in increased entrainment and increased cavity interactions. 
There is an annular gap around the RPV in the Zion plant that could allow some melt to be dispersed directly to the upper dome rather than into the subcompartments outside the cavi:y exit. Testing with an annular gap was not feasible in the SNL/ANL facilities because the melt generator and cavity assemblies were placed outside the containment vessel. The issue of the annular gap was addressed $i_{1}$ a later test in the Containment Technology Test Facility (i.e., SNL/IET-11). ${ }^{4}$

Certain details were neglected in the cavity model. In particular, the incore instrument guide tubes and their supports were not modeled. The guide tubes and their supports were simulated in the HIIPS-10S experiment [Allen et al. 1990], where they were forcibly ejected from the cavity by the dispersal process. In addition, the Zion plant has a "penthouse" over the cavity exit, which is a steel box intended to limit personnel access into the cavity during outages. It was judged that the penthouse could not withstand any significant pressurization of the cavity and would be blown clear of the exit. The TRG agreed that neglecting these structures would have minimal impact on DCH loads; and if anything, their omission would be conservative in that higher DCH loads would be expected.

A goal of the experiments was to geometrically model the subcompartment regions outside the cavity exit. The width of the SNL/ANL facilities played an important role in fixing the scale factors at $1: 10$ and $1: 40$, respectively. The steam generator room and the seal table room were accurately modeled in the experiments. Although models of the steam generators and reactor coolant pumps were included, some details of the subcompartments were excluded. In particular, the seal table (located above the cavity exit and at the entrance to the seal table room), and the

\footnotetext{
T.K. Blanchat et al., 1993, Ouick Look Report on the Eleventh Internd Effects Test (TET-11) in the Containment Technology Test Facility, Sandia National Laboratories, Albuquerque, NM.
}

extensive plumbing and cable trays were not modeled. The TRG agreed that neglecting these structures would have minimal impact on the experiment results; and if anything, their omission would lead to slightly conservative (higher) loads.

The total volume of the containment vessel was overscaled by $17 \%$. The correctly scaled volume for the Surtsey vessel was $76.8 \mathrm{~m}^{3}$. The SNL facility has an as-built volume of $103 \mathrm{~m}^{3}$, so it was decided to exclude some volume to better match Zion by building a false floor in the vessel. Existing support structures in the vessel dictated the position of the false floor such that the new volume was $89.8 \mathrm{~m}^{3}$, or $17 \%$ overscaled. The ANL counterpart facility was able to match this volume.

The aspect ratio of the SNL facility differs from Zion. In particular, the SNL facility is too tall and not wide enough. The deviation in aspect ratio was considered acceptable because most of the dispersed melt was expected to remain in the subcompartment and because any possible hydrogen combustion phenomena should not be significantly affected by the aspect ratio.

\subsubsection{Melt Mass and Composition}

The corium mass and composition for the Zion application are taken from the SASM effort [Zuber et al. 1991]. The SASM corium mass is for Surry so the values are scaled up for Zion based on core power. The core composition is similar for Surry and Zion, so no modification is required. The experiments employ thermite as a high temperature, chemically reactive simulant for corium. Table 2.4 compares the composition of thermite and corium, and Table 2.5 compares their material properties.

The SASM scaling study addressed RPV and cavity phenomena, but it stopped short of extending the analysis to the containment building. Geometric scaling of the melt mass for the experiment is not strictly applicable because 
of material property differences between corium and thermite. The amount of thermite used in the ixperiments was selected so that the experiments would have the same potential for pressurization as the reactor application.

The potential for pressurization is obtained by allowing airborne melt to come to thermal equilibrium with the atmosphere. The single cell equilibrium model [Pilch 1992] yields,

$$
\frac{\Delta P}{P^{0}}=\frac{\Delta E_{\mathrm{b}}+N_{d} \Delta e_{\mathrm{f}}+N_{d} \Delta e_{\mathrm{r}}}{U^{0}(1+\psi)}
$$

where

$$
\begin{aligned}
U^{\circ}= & \text { initial internal energy of the entire } \\
& \text { atmosphere, } \\
\Delta \mathrm{P}= & \text { pressure rise in the containment } \\
& \text { resulting from the } \mathrm{DCH} \text { event, } \\
\mathrm{P}^{0}= & \text { initial containment pressure, } \\
\Delta \mathrm{E}_{\mathrm{b}}= & \text { total energy delivered to the } \\
& \text { containment by blowdown of the } \\
& \text { RCS, } \\
\Delta \mathrm{e}_{\mathrm{l}}= & \text { specific thermal energy carried by } \\
& \text { the debris, } \\
\Delta \mathrm{e}_{\mathrm{r}}= & \text { specific chemical energy resulting } \\
& \text { from debris oxidation with steam, } \\
& \text { and } \\
\psi= & \text { heat capacity ratio. }
\end{aligned}
$$

A term for hydrogen combustion is not shown because inert atmospheres are employed in some of the counterpart experiments so that hydrogen production can be measured to validate models.

The heat capacity ratio appears because, at thermal equilibrium between airborne debris and the atmosphere, the debris still carries sensible heat that is not available for containment pressurization. The heat capacity ratio is defined by

$$
\psi=\frac{N_{d} C_{d}}{\left(N^{0}+N_{b}\right) C_{v}}
$$

where

$$
\begin{aligned}
& N_{d}=\text { number of debris moles } \\
& C_{d}=\text { molar heat capacity of debris, } \\
& \mathbf{N}^{0}=\text { number of gas moles initially in the } \\
& \text { cortainment, } \\
& \mathrm{N}_{\mathrm{b}}=\text { number of gas moles added to the }
\end{aligned}
$$

Equations (1) and (2) show how the containment pressurization depends on the amount (moles) of molten material participating in DCH. Table 2.6 shows input parameters for the reactor application and the counterpart experiments. The containment atmosphere in some of the counterpart tests was inerted, so hydrogen combustion was artificially suppressed in the reactor calculations. The melt mass selected for the experiments ensured that the potential for pressurization was preserved between the experiments and the reactor application.

Table 2.7 shows the fractional contribution of RCS blowdown energy, debris thermal energy, and debris oxidation energy to potential pressurization of the containment. Although agreement exists between the counterpart experiments, the fractional contribution of debris oxidation is underscaled in the experiments relative to the reactor application. 


\subsubsection{RCS or Accumulator Conditions}

The RCS pressure at the time of vessel breach is an important parameter controlling DCH. At very low RCS pressures, the prerequisites of efficient dispersal and fragmentation are not present for efficient DCH interactions; consequently, there is no motivation to test at very low pressures. At the other extreme, vessel breach at full system pressure probably represents the greatest DCH threat. NUREG-1150, however, indicates that the probability of rapid spontaneous depressurization (resulting from surge line, hot leg, or PORV failure) to very low pressures is likely to occur before bottom head failure, and more recent research tends in confirm this conclusion. Thus, intermediate pressures, as might result from a small break LOCA (e.g., pump seal failure), are the more likely scenarios that might lead to significant DCH loads. As a practical matter, the existing steam supply and accumulator at SNL was limited to $-6 \mathrm{MPa}$, which is quite consistent with NUREG-1150's assessment of RCS pressures at vessel breach resulting from a SBLOCA.

The RCS temperature, in conjunction with the pressure and volume, determine the number of moles of driving gas. RCS temperatures are bounded by saturation $(-600 \mathrm{~K})$ and a temperature where the surge line or hot leg is likely to fail $(\sim 1000 \mathrm{~K})$ with some intermediate temperature being the more likely. The SNL steam supply was limited to providing saturated steam and the volume of the existing steam accumulator tank was $0.29 \mathrm{~m}^{3}$; these limitations fixed the quantity of steam moles used in the IET experiments. The scaled quantity of steam in these experiments was approximately equal to Zion RCS conditions at $\sim 700 \mathrm{~K}$.

The composition of RCS gas in an NPP core melt accident is predominately steam with some hydrogen. Most of the hydrogen is produced from $\mathrm{Zr} /$ steam reactions that precede significant core degradation. Most of this hydrogen will be vented to the containment through whatever leak paths characterize the LOCA. Furthermore, melt relocation into the lower plenum flashes water into steam, which also flushes hydrogen from the RCS. Thus, most hydrogen produced in the RPV will be in the containment at the time of vessel breach. In the IET experiments, it was decided to drive the melt with pure steam. This choice enhanced the safety of the experiments and simplified the assessment of hydrogen produced/ burned in the experiments.

\subsubsection{Cavity and Basement Water}

Water in the containment is a natural consequence of the core melt accident. In fact, core melting can be initiated only if the core is first boiled dry. Steam produced by excessive temperatures in the RPV is vented to the containment through the PORV's or through any other small break that may exist in the system. Steam vented from the RCS enters the containment atmosphere where it begins to condense, both in the atmosphere itself (heating the atmosphere to saturated conditions) and on structures.

Cavity water is often viewed as a potential mitigator of DCH loads. The premise is that melt/water interactions are efficient (i.e., debris energy goes into water vaporization rather than heating the atmosphere) and are nonenergetic. The DCH testing program to date has not fully substantiated this premise. The WC-1 and WC-2 tests [Allen et al. 1992a] were conducted under similar initial conditions, except that the WC-2 test had a small amount of water in the cavity (i.e., $11.76 \mathrm{~kg}$ ). Test results indicate that a little more hydrogen was produced in WC-2 but that the impact on containment loads was negligible. However, the amount of cavity water was so small that large effects might not be expected.

Three HIPS tests [Tarbell et al. 1991] were conducted with cavity water: two with full cavities and one with a half filled cavity. Large steam explosions that destroyed the test apparatus were observed in all three tests. Test observations seem to indicate that the bulk of the 
water was ejected as a slug prior to melt dispersal, thus creating a separation between most of the water phase and the melt. This suggests that large quantities of water may not be an efficient heat sink for DCH. However, this conclusion remains speculative because the HIPS tests were not conducted inside Surtsey where hydrogen production and containment loads could be measured. In addition, they did not have subcompartment structures to trap water and deflect it back into the debris plume, making debris/water interactions much more efficient.

For a full station blackout accident in which the upper dome sprays do not operate, the only water found in the reactor cavity comes from condensation in the cavity itself. Prorating the total steam delivered to the containment by the ratio of cavity surface area to total containment surface area yields $2.6 \mathrm{mt}$ of water in the Zion cavity. Scaled quantities of cavity water were employed in the IET counterpart experiments. The maximum pressure reduction that water could have on the containment pressurization is given by

$$
\frac{\Delta P_{w}}{P^{0}}=\frac{N_{w} \Delta e_{w}-R_{u} T^{0} N_{w}}{U^{0}(1+\psi)}
$$

where

$$
\begin{aligned}
\mathbf{N}_{w}= & \text { moles of water, } \\
\Delta \mathbf{e}_{w}= & \begin{array}{l}
\text { molar heat of vaporization for } \\
\text { water, }
\end{array} \\
\mathrm{U}^{0}= & \text { initial internal energy of the entire } \\
& \text { containment atmosphere, and } \\
\psi & =\text { heat capacity ratio. }
\end{aligned}
$$

The amount of water actually used in most of the IET experiments $(3.48 \mathrm{~kg})$ ensures that this small amount of water represents the same relative heat sink in the experiment as would be expected in Zion. The cavity water used in the IET experiments exceeds the geometrically scaled value of $2.6 \mathrm{~kg}$ because the Surtsey volume is overscaled and because the Surtsey atmosphere has a slightly different heat capacity due to differences in the composition of the atmosphere. IET-1 through IET-7 (excluding the IET-2 series) had condensate levels of water in the cavity.

Other accident scenarios (i.e., bleed and feed scenarios similar to TMI can result in significantly greater quantities of water in the cavity. In addition, even in station blackout scenarios, the Zion cavity is likely to be flooded since a separate diesel generator for the upper dome sprays is available and since the entrance to the incore instrument tunnel is designed to flood if water is on the basement floor. Such deeply flooded situations would submerge the RPV, which would likely prevent RPV failure; this is an area of ongoing research. Thus, since full cavities are not expected to result in a HPME, intermediate levels of water (approximately half full) are of greater interest to DCH. The TRG recommended testing at this intermediate level of water.

Two experiments were conducted to answer questions on the effect of water in the cavity, IET-8A and IET-8B. The amount of water required to fill the cavity approximately one-half full was $62 \mathrm{~kg}$. The molten charge in these experiments was $43 \mathrm{~kg}$ of thermite, which has a maximum energy density of $3.14 \mathrm{MJ} / \mathrm{kg}$ assuming complete oxidation of all the metals. Assuming the heat of vaporization of water is $2.2 \mathrm{MJ} / \mathrm{kg}, 62 \mathrm{~kg}$ of water is enough to exactly quench all of the molten debris.

Water can also accumulate on the basement floor during a reactor accident, and some of the IET tests had water on the basement floor. The total amount of water in the Zion RCS is $267 \mathrm{mt}$. For a station blackout accident, most of this water must boil off in order to get into a core melt accident. An upper bound to the amount of water on the containment floor can be determined if it is assumed that the entire RCS inventory is 
delivered to the containment as steam. Not all of the water released from the Zion RCS is condensed on containment structures. Approximately one atmosphere of saturated steam (representing $45 \mathrm{mt}$ ) remains in the containment atmosphere. The maximum amount of water that can condense on excavity structures is $219 \mathrm{mt}$. It is recognized that some of this water will reside as films on containment structures. However, as a bound it was assumed that all 219 $\mathrm{mt}$ of condensed water outside the cavity will accumulate on the basement floor. This translates to a depth of $15 \mathrm{~cm}$, which is the height of the curb around the cavity exit at Zion. This depth was geometrically scaled in the IET experiments (i.e. $-1.5 \mathrm{~cm}$ ) and was slightly larger than the amount necessary to quench all of the dispersed melt. The containment basement water $(71 \mathrm{~kg}$ ) was underscaled on a mass basis relative to Zion because the annulus between the containment wall and the cranewall is not fully represented in the experiments because of space limitations. The TRG agreed that underscaling of the basement water would have little impact on the results; and if anything, it would favor conservative (i.e., higher) containment loads in the experiments.

\subsubsection{Containment Conditions}

Unpublished calculations with the CONTAIN code for the Surry plant indicate that the containment pressure at vessel breach is $-0.17 \mathrm{MPa}$, but Surry is a subatmospheric plant while Zion is not. Correcting for this difference gives $\sim 0.20 \mathrm{MPa}$ for Zion. This was the basis for the initial containment pressure in the SNL/ANL courterpart tests. In addition, the reactor atmosphere is expected to be near saturation, i.e., $\sim 370 \mathrm{~K}$. The experiments were conducted at ambient temperatures $(\sim 300 \mathrm{~K})$ since there was no way to heat the atmosphere.

The containment atmosphere at the time of vessel breach is composed of $\sim 0.1 \mathrm{MPa}$ of air, $\sim 0.1 \mathrm{MPa}$ steam, and some hydrogen that has leaked from the RCS. Steam, as an atmosphere constituent, could not be employed in the experiments because a steam supply was not available and because the atmosphere and structures could not be preheated to preveni excessive condensation. Nitrogen was employed in the IET experiments as a substitute for steam. The flammability charts of Kumar [1985] suggest that nitrogen is similar to steam in its inerting effect on hydrogen combustion. The TRG recommended conducting one test with $\mathrm{CO}_{2}$ (a triatomic molecule like steam) because it is more generally recognized as a surrogate for steam with regard to hydrogen combustion.

Preexisting hydrogen was simulated in some of the IET experiments. Preexisting hydrogen in the containment at the time of vessel breach is produced primarily by clad oxidation during the core degradation process. The Zion NPP contains $20.2 \mathrm{mt}$ of $\mathrm{Zr}\left(2.22 \times 10^{5}\right.$ moles of $\left.\mathrm{Zr}\right)$ in the core, and if some fraction $\left(f_{\mathrm{zr}}\right)$ oxidizes, then

$$
N_{\mathrm{HD}}=\mathrm{f}_{\mathrm{zx}} 4.4 \times 10^{5}
$$

moles of hydrogen can be produced. A bounding result is obtained by assuming all of this hydrogen is released to the containment.

The mole fraction of $\mathrm{H}_{2}$ in the Zion atmosphere can be computed from

$$
\mathbf{X}_{\mathrm{HD}}=\frac{\mathbf{P}_{\mathrm{HD}}}{\mathbf{P}_{\mathrm{HL}}+\mathbf{P}_{\mathrm{AIR}}+\mathbf{P}_{\mathrm{STM}}},
$$

where

$$
\begin{aligned}
& \mathrm{P}_{\mathrm{ARR}}=\underset{\substack{\text { and } \\
\text { aPa, partial pressure of air, }}}{0.1 \mathrm{MPa}} \\
& P_{\text {STM }}=0.1 \mathrm{MPa} \text {, partial pressure of } \\
& \mathbf{P}_{\mathrm{HZ}}=\text { partial pressure of } \mathrm{H}_{2} \text {. }
\end{aligned}
$$


The partial pressure of hydrogen in the Zion containment atmosphere,

$$
\begin{aligned}
P_{\mathrm{H} 2} & =\frac{N_{\mathrm{H}} R_{u} T}{V} \\
& =\frac{f_{\mathrm{zr}}\left(4.44 \times 10^{5}\right)(8.314)(375)}{76.9 \times 10^{3}} \\
& =0.018 \mathrm{f}_{\mathrm{zr}}(\mathrm{MPa})
\end{aligned}
$$

is a function of the $\mathrm{Zr}$ oxidation fraction $\left(\mathrm{f}_{\mathrm{zr}}\right)$. The mole fraction of hydrogen in the atmosphere is more conveniently written as

$$
X_{\mathrm{H} 2}=\frac{0.018 f_{z_{r}}}{0.018 f_{z_{r}}+0.1+0.1}
$$

Table 2.8 summarizes preexisting hydrogen concentrations for the Zion NPP as a function of the amount of $\mathrm{Zr}$ oxidized. The first three oxidation fractions were taken from NUREG1150. The fourth oxidation fraction was taken from NUREG/CR-4624 (Vol. 5) for the Zion NPP. The shaded box was selected as the design basis for IET-6 because this hydrogen concentration is not flammable without the high temperatures and additional hydrogen produced in the HPME event.

The IET-6 experiment had the same concentrations of preexisting hydrogen as the design basis Zion application. This choice preserved the potential for containment pressurization $\left(\Delta \mathrm{P} / \mathrm{P}^{\circ}=4.5\right)$, based on the single-cell equilibrium model between the experiment and the reactor application, and it also preserved the relative contribution due to hydrogen combustion (51\%).

The majority of the IET tests were conducted with the following initial conditions: (1) the melt simulant was $43 \mathrm{~kg}$ of iron oxide/aluminum/ chromium powder; (2) the driving gas was $\approx 500 \mathrm{~g} \cdot$ moles of superheated steam $(\approx 580 \mathrm{~K})$ at an initial absolute pressure of 6.3 $\mathrm{MPa}$; (3) the initial absolute pressure in the Surtsey vessel was $\approx 0.2 \mathrm{MPa}$; and (4) the initial hole diameter was $3.5 \mathrm{~cm}$, but the graphite limitor plate was dissolved by molten iron so that the final hole diameter was approximately $4 \mathrm{~cm}$. The Surtsey vessel gas concentrations were varied. The cavity contained either a scaled condensate level of water or was one-half full, and the containment basement floor was either dry or contained a scaled condensate level of water. Table 2.9 lists the exact initial conditions for all of the IET experiments.

\subsection{Measurements and Instrumentation}

The most significant variables measured in the IET experiments were (1) the increase in pressure and temperature in the Surtsey vessel, (2) the cavity pressure, (3) the number of $\mathrm{g} \cdot$ moles of hydrogen generated by the reaction of metallic debris with steam and water, (4) the number of $\mathrm{g} \cdot$ moles of hydrogen bumed, (5) the debris temperature, (6) the debris particle size, and (7) the mass and location of debris recovered from the Surtsey vessel. The instrumentation and techniques used to make these measurements are described in the sections below.

\subsubsection{Pressure Measurements}

Six pressure transducers with a range of 0-0.69 $\mathrm{MPa}$, two at each level 1,3 , and 5 (channels 21 through 26 in Figures 2.1 and 2.8), were used to measure the pressure in the upper dome of the Surtsey vessel in the IET experiments. These transducers were mounted in tapped holes in instrument penetration ports in the sides of the Surtsey vessel. The tapped holes were filled with steel turnings to protect the sensing ends from direct impact with molten debris. In addition, pressure transducers with a range of 0-6.9 $\mathrm{MPa}$ were used to measure the gas pressure in the crucible above the thermite (channels 34 and 35 in Figures 2.2, 2.3, and 2.4). A pressure transducer with a range of 0 1.4 $\mathrm{MPa}$ was used to measure the gas pressure in 
the scaled reactor cavity (channel 36 in Figures 2.3 and 2.4). Another pressure transducer with a range of 0-7.0 $\mathrm{MPa}$ was used to measure the pressure in the cavity below the water line (channel 31 in Figures 2.3 and 2.4). Pressure transducers with a range of $0-0.69 \mathrm{MPa}$ were used to measure the gas pressure in the subcompartment structures and in the seal table room (channels 39 and 40 in Figures 2.5, 2.6, and 2.7). These transducers were metal diaphragm strain gauge-type pressure transducers (Model 141-1, Precise Sensor, Inc., Monrovia, CA). In addition, two pressure transducers were embedded in the concrete walls of the round section of the cavity under the melt generator (labeled P1 and P2 in Figures 2.3 and 2.4) and were piezoelectric-type gauges with a range of 0-6.9 $\mathrm{MPa}$. The specified accuracy from the manufacturer for the pressure transducers is less than \pm 0.50 percent at full-scale output. These instruments are routinely recalibrated at SNL against instruments traceable to the National Institute of Standards and Technology, and accuracies are always within the manufacturer's specifications. The frequency response is $22 \mathrm{kHz}$ (16 $\mu$ s rise time) for the 0-0.69 $\mathrm{MPa}$ range pressure transducers and $36 \mathrm{kHz}$ (10 $\mu$ s rise time) for the 0-6.9 $\mathrm{MPa}$ range pressure transducers. The data acquisition system recorded data from the pressure transducers at a rate of 1400 data points per second per channel from thermite ignition to about 60 seconds following the HPME transient.

\subsubsection{Gas Temperature Measurements}

The gas temperatures in the Surtsey vessel were measured with five aspirated thermocouple assemblies. An aspirated thermocouple assembly consisted of three bare type-K thermocouples (0.127-mm wire) mounted in an anodized aluminum tube. Each tube was opened with a solenoid-operated valve that was actuated remotely by a signal from the photodiode under the melt plug immediately after the HPME transient. One of these assemblies was installed through instrumentation ports at each level 1,3 , and 5 (channels 41 through 49 in Figures 2.1 and 2.8). A thermocouple assembly was also installed through the refueling canal wall just above the radial concrete beam on the same side as the instrument tunnel exit. This thermocouple assembly was used to measure gas temperatures inside the subcompartment structures (channels 51,52 , and 53 in Figures 2.5, 2.6, and 2.7). Another thermocouple assembly was installed through the crane wall into the seal table room (channels 54, 55, and 56 in Figures 2.5, 2.6, and 2.7).

Calculations by SNL have shown that the worstcase temperature underprediction by the thermocouple assemblies would be 13 percent at the beginning of the HPME event when the gas temperatures are low, and 6 percent when the gas temperatures have peaked. 5 Type-K thermocouples (channels 68 through 77 in Figures 2.6 and 2.9) were installed in the Surtsey vessel in IET-4, IET-5, IET-6, IET-7, IET-8A, and IET$8 \mathrm{~B}$ to measure bulk gas temperature above the operating deck. The array consisted of ten approximately equally spaced thermocouples. The array was suspended above the refueling canal at the vessel centerline. Figure 2.9 shows the spacing and relative position of the thermocouples. All type-K thermocouples were made of $0.254-\mathrm{mm}$ wire with a $1.6-\mathrm{mm}$ sheath. The temperature range was $273 \mathrm{~K}$ to $1523 \mathrm{~K}$. The maximum error using the manufacturer's calibration is $\pm 9.4 \mathrm{~K}$ at $1523 \mathrm{~K}$ with a $0.3-\mathrm{s}$ time constant. The thermocouples had the sheath removed at the tip, exposing the junction to ensure a fast response time.

Four type-K thermocouples (channels 66, 67, 98, and 99 in Figures 2.6 and 2.7) were installed inside the triangular vent space above the $1 \mathrm{~A}$, 1B, 1C, and 1D RCPs. These thermocouples measured the temperature of the gas as it exited

\footnotetext{
${ }^{5}$ T.K. Blanchat, May 1992, "Aspirated Thermocouple Calculations," Letter Report to the U.S. Nuclear Regulatory Commission, Sandia National Laboratories, Albuquerque, NM.
} 
the subcompartment structures. Four type-K thermocouples (channels $11,12,13$, and 14 in Figures 2.5, 2.6, and 2.7) were installed approximately $10 \mathrm{~cm}$ below the $1 \mathrm{~A}, 1 \mathrm{~B}, 1 \mathrm{C}$, and ID RCPs. These thermocouples measured the temperature of the gas as it flowed through the subcompartment structures. The temperature of the driving gas in the steam accumulator tank was measured using two type-K thermocouples (channels 91 and 92 in Figure 2.4) that extended through the accumulator shell and were secured in place using pressure-tight fittings. Measurements from these thermocouples were important because the measured temperature and pressure in the accumulator tank were used to calculate the number of $g \cdot$ moles of steam driving gas.

\subsubsection{Debris Temperature Measurements}

Debris temperature was measured in all of the IET experiments using type-C thermocouples and optical pyrometers. The four high-temperature tungsten-rhenium type-C thermocouples (channels 7, 8, and 9 in Figures 2.5 and 2.6, and channel 10 in Figure 2.3) were made of 0.38-mm-diameter wire with a 1.6-mm-diameter stainless steel sheath and were installed at the chute exit, at the seal table room floor opening, on the crane wall at the debris flight-path contact point, and on the cavity floor. These thermocouples measured the temperature of the debris as it exited the cavity and entered the subcompartment structures. The temperature range for the thermocouples was $273 \mathrm{~K}$ to $2593 \mathrm{~K}$. The maximum error using the manufacturer's calibration is $\pm 25.9 \mathrm{~K}$ with a 0.9-s time constant. The measurements from these type-C thermocouples were erratic and unreliable because they were usually struck directly by molten debris.

Two pyrometers (channels 37 and 38 in Figures $2.5,2.6$, and 2.7) were used to measure the temperature of the debris as it exited the instrument tunnel into the containment basement. An optical pyrometer (type 11x20, Ircon Inc., Niles, II) was located inside the biological shield wall and was focused just above the instrument tunnel exit through a fused silica window sealed inside the biological shield wall. Another optical pyrometer (type 11×30, Ircon Inc., Niles, II) was located outside the crane wall and was focused through a fused silica window sealed inside the crane wall. The focal point was the window surface, which was directly in the flight path of the debris ejected from the cavity. The data from these instruments were erratic and unreliable, probably due to high aerosol concentrations in the optical path to the sensor head.

Since the debris temperature could not be measured accurately in the scaled Zion structures, a separate test series (IET-2) was performed specifically to measure the temperature of the molten thermite jet as it exited the melt generator. The IET-2 test series consisted of three separate experiments: IET-2A, IET-2B, and IET-2C.

\subsubsection{IET-2 Experiment Description}

In these tests, the melt generator setup was not attached to the scaled reactor cavity or to the Surtsey vessel, but was instead attached to a nondispersive cavity that is described below. Figure 2.10 is a composite view of the highpressure steam boiler, steam accumulator, burst diaphragm, melt generator, and nondispersive cavity used in the IET-2 experiments. The meit generator was the same one used in the other IET tests (Figure 2.2). In the IET-2A and IET-2B experiments, the melt generator/crucible had a hemispherical bottom head containing a graphite limiter plate with a $3.5-\mathrm{cm}$ exit hole. In the IET2C experiment, the high-pressure steam supply system was not used and the exit hole was $10 \mathrm{~cm}$ in diameter.

The cavity used in the IET-2 tests was a nondispersive cavity that was designed to prevent debris and aerosol release to the environment. An isometric view of the nondispersive cavity is shown in Figure 2.11. The debris catcher utilized a rock-bed filter to trap much of the debris and aerosols generated in the tests and 
limit the amount dispersed to the environment. In addition, the apparatus had sight tubes that allowed pyrometers to measure the temperature of the thermite jet exiting the melt generator without interference from aerosols.

Figure 2.12 is an end view of the melt generator and nondispersive cavity. A graphite-lined flow tube was placed at the exit of the melt generator. Sight tubes were attached to penetrations in the flow tube so that pyrometers could view the melt from the side without interference from aerosols. To protect the pyrometers, the sight tubes had a quartz window on the pyrometer end, and a steel plate with a $0.5-\mathrm{cm}$ diameter center hole on the flow tube end. A pyrometer mounted directly under the melt exit was protected with a $10-\mathrm{cm}$ diameter Lucite window on the melt side and a quartz window on the pyrometer side.

Figure 2.13 presents a side view of the cavity and melt generator. The nondispersive cavity was constructed from a $76.2-\mathrm{cm}$ diameter pipe section that was $182.8 \mathrm{~cm}$ long and lined with concrete. The melt generator was welded to the top center of the nondispersive cavity. The cavity was designed to trap and cool molten debris and aeroscl as the material moved through openings at both ends. The filter medium was river rock of assorted sizes held in place with metal grating. There was approximately $1 \mathrm{~m}$ of river rock between the melt generator and the openings at the ends of the cavity.

In the IET-2A and IET-2B experiments, the steam accumulator tank was pressurized to $\approx 6 \mathrm{MPa}$ with superheated steam. After the pressurization sequence, the thermite mixture was ignited remotely with a braided wire fuse placed on top of the compacted thermite. After the thermite was ignited, the pressure in the crucible rapidly increased. The pressure increase verified that the thermite reaction had started, and signaled the operator to fail the burst diaphragm separating the steam accumulator tank and the molten thermite in the melt generator. This brought superheated steam into contact with the molten thermite. Upon contacting and failing a fusible brass plug at the bottom of the crucible, the molten thermite in the crucible was expelled by high-pressure steam into the cavity. In the IET-2C experiment, the steam supply system was removed, and a blind flange was attached to the burst diaphragm flange to seal the system. The crucible was purged with nitrogen and then pressurized with nitrogen to $0.3 \mathrm{MPa}$ prior to thermite ignition.

Table 2.10 lists the initial conditions of the three IET-2 experiments. All of the IET-2 tests were conducted using a melt simulant composed of $43 \mathrm{~kg}$ of iron oxide/aluminum/chromium powder. The driving gas for IET-2A was $\approx 464$ moles of superheated steam $(\approx 588 \mathrm{~K})$ at an initial absolute pressure of $6.1 \mathrm{MPa}$. The driving gas for IET-2B was $\approx 418$ moles of superheated steam $(\approx 588 \mathrm{~K})$ at an initial absolute pressure of $5.8 \mathrm{MPa}$. The driving gas for IET-2C was $\approx 2$ moles of nitrogen at an initial absolute pressure of $0.3 \mathrm{MPa}$.

\subsubsection{EET-2 Instrumentation}

Table 2.11 is a listing of the instrumentation used in the IET-2 experiments, including the channel number, type, purpose, and location of each instrument. The circled numbers in Figures 2.10 through 2.13 correspond to the channel numbers in the data acquisition system listed in Table 2.4. Zero time for HPME was set by the data acquisition system as the time at which the melt failed the brass plug and entered the cavity. The event was signaled by a photodiode located at the melt plug exit. When the hot melt burst through the brass plug, the intense light emitted from the melt caused the photodiode to emit a signal that was used to mark the initiation of the HPME.

Pressure transducers with a range of 0-6.9 $\mathrm{MPa}$ were used to measure the gas pressure in the accumulator tank (Channels 31 and 32 in Figure 2.10 ), in the crucible above the thermite (Channels 34 and 35 in Figure 2.10), in the burst diaphragm (Channel 33 in Figure 2.10), and in 
the nondispersive cavity (Channel 36 in Figures $2.10,2.12$ and 2.13). These transducers were metal diaphragm strain gauge-type pressure transducers (Model 141-1, Precise Sensor, Inc., Monrovia, CA). The data acquisition system recorded data from the pressure transducers at a rate of 1400 data points per second from thermite ignition to about 60 seconds following the HPME transient.

The temperature of the driving gas in the steam accumulator tank was measured using two type-K thermocouples (Channels 91 and 92 in Figure 2.10). Measurements from these thermocouples were important because the measured temperature and pressure in the accumulator tank were used to calculate the number of moles of steam driving gas.

Three pyrometers (Channels 16, 38, and 39 in Figures 2.11, 2.12 and 2.13) were used to measure the temperature of the molten thermite as it exited the melt generator. Two pyrometers, an optical pyrometer (type 11x30, Ircon Inc., Niles, IL) and a two-color pyrometer, were located on the outside east and west face of the cavity. They were focused just below the melt generator exit through a fused silica window sealed in a sight tube, and were used to determine the outside surface temperature of the debris jet. Another optical pyrometer (type 11x30, Ircon Inc., Niles, IL) was located under the nondispersive cavity directly below the melt generator exit. This pyrometer, installed for the IET-2B and IET-2C tests, was used to measure the core temperature of the debris jet. A debris emissivity of 0.9 was assumed when converting the results (in $\mathrm{mV}$ ) from the optical pyrometers to temperature (in $\mathbf{K}$ ). A debris emissivity near the blackbody value was assumed because the debris appeared black when inspected posttest. The calculated debris temperature is not very sensitive to the assumed debris emissivity. For example, at approximately $2000 \mathrm{~K}$ a 13 percent change in the assumed emissivity resulted in only a 1.9 percent change in the calculated debris temperature.
The optical pyrometers had a response time of $1.5 \mathrm{~ms}$ to 95 percent of their full range. The controllers for the optical pyrometers were capable of measuring temperatures between $1973 \mathrm{~K}$ and $3073 \mathrm{~K}$ with a specified accuracy of 1 percent of the full-scale temperature. The twocolor pyrometer had a temperature response range of $1773 \mathrm{~K}$ to $3773 \mathrm{~K}$. In a transient event such as a HPME experiment, the accuracy of the pyrometer measurements was expected to be no better than $\pm 25 \mathrm{~K}$. The pyrometers were factory calibrated and the type $11 \times 30$ pyrometer is routinely recalibrated by the Sandia Radiant Heat Facility.

Two type-C thermocouples measured the melt temperature in the top of the crucible and the gas temperature in the top of the cavity (Channel 12 in Figures 2.10, 2.12, and 2.13). These thermocouples were comprised of $0.51-\mathrm{mm}$ wire with a 3.2-mm $\mathrm{MgO}$ insulator sheath and were used only in the IET-2B experiment. The temperature range of a type-C thermocouple is $273-2593 \mathrm{~K}$. The maximum limit of error using the manufacturer's calibration is $\pm 25.9 \mathrm{~K}$ at $2593 \mathrm{~K}$ with a 0.9 s time constant.

Data points from the thermocouples and the pyrometers were recorded by the data acquisition system at a rate of 10 per second prior to thermite ignition. Just prior to ignition the data acquisition system was switched to the fast data acquisition mode, in which data points were recorded at a rate of 1400 per second.

Two high-speed (1000 frames per second) 16-mm cameras were focused on the melt jet below the exit hole. These cameras were used to characterize the melt stream transient flow regimes: single phase liquid, two phase liquid and steam, and single phase steam. A VHS video camera recorded the event external to the cavity and was located approximately $15 \mathrm{~m}$ from the south end of the nondispersive cavity. 


\subsubsection{Gas Compostion}

In the IET tests (excluding the IET-2 tests), pre-evacuated $500-\mathrm{cm}^{3}$ gas grab sample bottles were used to collect samples from the Surtsey vessel (labeled L2, L4, and L6 in Figures 2.1 and 2.8) and the cavity (labeled $C$ in Figure 2.3) at several locations and times. One background sample in the cavity was obtained by opening solenoid valves manually for $10 \mathrm{~s}$ about 10 minutes prior to ignition of the thermite. Three background samples at levels 2, 4, and 6 were obtained by opening solenoid valves remotely for $10 \mathrm{~s}$ just prior to ignition of the thermite. Four gas grab sample bottles inside the subcompartment structures were opened at the following times: two bottles were opened at $2 \mathrm{~s}$ and remained opened for $5 \mathrm{~s}$; one bottle was opened at $15 \mathrm{~s}$ and remained open for $10 \mathrm{~s}$; and one bottle was opened at 2 min and remained opened for $10 \mathrm{~s}$. Three gas grab sample bottles at levels 2,4 , and 6 were opened remotely for 10 seconds at 2 minutes after melt ejection. Three gas grab sample bottles at levels 2,4 , and 6 were opened manually for 10 seconds at $\approx 30$ minutes after melt ejection. In addition, two gas grab sampless were taken from the cavity following melt ejection: one was opened as melt ejection was initiated and remained open for 2 seconds, and the other was opened at $0.5 \mathrm{~s}$ following melt ejection and remained open for $2 \mathrm{~s}$. The gas samples were analyzed using gas mass spectroscopy by Battelle Pacific Northwest Laboratories in Richland, WA.

Tests were performed to measure the fill times of the $500-\mathrm{cm}^{3}$ gas grab sample bottles at three different pressures (atmospheric, $0.26 \mathrm{MPa}$, and $0.43 \mathrm{MPa}$ ). An evacuated bottle was separated from a pressure source by a remotely operated solenoid valve. A pressure transducer was installed downstream of the valve and pressure source, and the fill time was recorded by the data acquisition system. The data indicate that all bottles were filled in less than $2 \mathrm{~s}$, regardless of the upstream pressure.

\subsubsection{Poettest Debris Recovery}

The total debris mass dispersed into the Surtsey vessel and the debris mass in specific locations were determined by a very careful posttest debris recovery procedure. Debris in the Surtsey vessel was recovered from four basic locations: from inside the subcompartment structures, i.e., inside the crane wall below the operating deck, (2) from the Surtsey vessel outside the structures, (3) from the cavity and instrument tunnel chute, and (4) from the crucible.

\subsubsection{Debris Velocity}

Breakwires were placed across the opening from the containment basement to the seal table room and at the opening in the ceiling of the seal table room (channels 16 and 17 in Figures 2.5 and 2.6). When the debris front severed the breakwire, a timing signal was recorded by the data acquisition system. The breakwire was intended to give timing information on entry of debris into and out of the seal table room.

\subsubsection{Cameras}

Typically, two high-speed 16-mm cameras were used. Two cameras were mounted outside the Surtsey vessel: one on the top port focused downward on the operating deck, and one on the level-3 port focused horizontally across the vessel. In IET-5, IET-6, and IET-7, a high-speed camera was mounted inside the vessel. The camera inside the Surtsey vessel was located outside the crane wall and viewed a grid in front of the chute exit. The grid (2.54-cm squares) was constructed of 1.65-mm-diameter buss wire (tinned copper). The purpose of this camera was to determine if the subcompartment structures filled immediately with aerosols, thus obstructing the optical pyrometers. This camera was also used to obtain information concerning the debris flow regime and velocity. In addition to the highspeed cameras, two camcorders were used. One camcorder was mounted on the top port of the 


\section{Experiment Description}

Surtsey vessel and focused downward to film the HPME event, and the other camcorder was set up outside to give an overall view of the Surtsey vessel and high-pressure melt ejection system. 
Table 2.1 IET instrumentation location and purpose

\begin{tabular}{|c|c|c|c|}
\hline $\begin{array}{l}\text { Channel } \\
\text { number }\end{array}$ & Instrument & Location & Purpose \\
\hline 7 & $\begin{array}{l}\text { Thermocouple } \\
\text { Type-C }\end{array}$ & Chute Exit & $\begin{array}{l}\text { Measure Temperature at } \\
\text { Chute Exit }\end{array}$ \\
\hline 8 & $\begin{array}{l}\text { Thermocouple } \\
\text { Type-C }\end{array}$ & $\begin{array}{l}\text { Seal Table Room } \\
\text { Floor }\end{array}$ & $\begin{array}{l}\text { Measure Temperature at } \\
\text { Seal Table }\end{array}$ \\
\hline 9 & $\begin{array}{l}\text { Thermocouple } \\
\text { Type-C }\end{array}$ & $\begin{array}{l}\text { Crane Wall at } \\
\text { Debris Flight Path } \\
\text { Contact Point }\end{array}$ & $\begin{array}{l}\text { Measure Temperature } \\
\text { Inside Subcompartment } \\
\text { Structures }\end{array}$ \\
\hline 10 & $\begin{array}{l}\text { Thermocouple } \\
\text { Type-C }\end{array}$ & Cavity Floor & $\begin{array}{l}\text { Measure Temperature } \\
\text { Inside Cavity }\end{array}$ \\
\hline 11 & Thermocouple & Under RCP $1 \mathrm{~A}$ & $\begin{array}{l}\text { Measure Temperature } \\
\text { Insicie Subcompartment } \\
\text { Structures }\end{array}$ \\
\hline 12 & Thermocouple & Under RCP 1B & $\begin{array}{l}\text { Measure Temperature } \\
\text { Inside Subcompartment } \\
\text { Structures }\end{array}$ \\
\hline 13 & Thermocouple & Under RCP 1C & $\begin{array}{l}\text { Measure Temperature } \\
\text { Inside Subiompartment } \\
\text { Structures }\end{array}$ \\
\hline 14 & Thermocouple & Under RCP 1D & $\begin{array}{l}\text { Measure Temperature } \\
\text { Inside Subcompartment } \\
\text { Structures }\end{array}$ \\
\hline 16 & Breakwire & $\begin{array}{l}\text { Seal Table Room } \\
\text { Plug }\end{array}$ & Measure Debris Velocity \\
\hline 17 & Breakwire & $\begin{array}{l}\text { On Seal Table Room } \\
\text { Floor }\end{array}$ & Measure Debris Velocity \\
\hline 18 & Photodiode & Photodiode & $\begin{array}{l}\text { Signal Initiation of } \\
\text { HPME }\end{array}$ \\
\hline 19 & Pressure Transducer & $\begin{array}{l}\text { Refueling Canal } \\
\text { Wall }\end{array}$ & $\begin{array}{l}\text { Measure Gas Pressure } \\
\text { Inside Subcompartment } \\
\text { Structures }\end{array}$ \\
\hline 20 & Pressure Transducer & Seal Table Room & $\begin{array}{l}\text { Measure Gas Pressure } \\
\text { Inside Seal Table Room }\end{array}$ \\
\hline
\end{tabular}


Table 2.1 IET instrumentation location and purpose (continued)

\begin{tabular}{|c|c|c|c|}
\hline $\begin{array}{l}\text { Channel } \\
\text { number }\end{array}$ & Instrument & Location & Purpose \\
\hline 21 & Pressure Transducer & Level 1 & $\begin{array}{l}\text { Measure Gas Pressure in } \\
\text { Surtsey Vessel }\end{array}$ \\
\hline 22 & Pressure Transducer & Level 1 & $\begin{array}{l}\text { Measure Gas Pressure in } \\
\text { Surtsey Vessel }\end{array}$ \\
\hline 23 & Pressure Transducer & Level 3 & $\begin{array}{l}\text { Measure Gas Pressure in } \\
\text { Surtsey Vessel }\end{array}$ \\
\hline 24 & Pressure Transducer & Level 3 & $\begin{array}{l}\text { Measure Gas Pressure in } \\
\text { Surtsey Vessel }\end{array}$ \\
\hline 25 & Pressure Transducer & Level 5 & $\begin{array}{l}\text { Measure Gas Pressure in } \\
\text { Surtsey Vessel }\end{array}$ \\
\hline 26 & Pressure Transducer & Level 5 & $\begin{array}{l}\text { Measure Gas Pressure in } \\
\text { Surtsey Vessel }\end{array}$ \\
\hline 31 & Pressure Transducer & Cavity & $\begin{array}{l}\text { Measure Water Pressure } \\
\text { in the Cavity }\end{array}$ \\
\hline 32 & Pressure Transducer & Accumulator & $\begin{array}{l}\text { Measure Gas Pressure in } \\
\text { Accumulator Tank }\end{array}$ \\
\hline 33 & Pressure Transducer & Burst Diaphragm & Measure Gas Pressure \\
\hline 34 & Pressure Transducer & Crucible & Measure Gas Pressure \\
\hline 35 & Pressure Transducer & Crucible & Measure Gas Pressure \\
\hline 36 & Pressure Transducer & Cavity & $\begin{array}{l}\text { Measure Gas Pressure in } \\
\text { the Cavity }\end{array}$ \\
\hline 37 & $\begin{array}{l}\text { Optical Pyrometer } \\
\text { Type } 11 \times 20\end{array}$ & $\begin{array}{l}\text { Inside Biological } \\
\text { Shield Wall - } \\
\text { Focused Above } \\
\text { Instrument Tunnel } \\
\text { Exit }\end{array}$ & $\begin{array}{l}\text { Measure Debris } \\
\text { Temperature as it } \\
\text { Entered Subcompartment } \\
\text { Structures }\end{array}$ \\
\hline 38 & $\begin{array}{l}\text { Optical Pyrometer } \\
\text { Type } 11 \times 30\end{array}$ & $\begin{array}{l}\text { Outside Crane } \\
\text { Wall - Focused on } \\
\text { Debris Flight Path } \\
\text { Contact Point }\end{array}$ & $\begin{array}{l}\text { Measure Debris } \\
\text { Temperature as it } \\
\text { Entered Subcompartment } \\
\text { Structures }\end{array}$ \\
\hline
\end{tabular}


Table 2.1 IET instrumentation location and purpoce (continued)

\begin{tabular}{|c|c|c|c|}
\hline $\begin{array}{l}\text { Channel } \\
\text { number }\end{array}$ & Instrument & Locention & Purpose \\
\hline 39 & Pressure Transducer & Refueling Canal & $\begin{array}{l}\text { Measure Gas Pressure } \\
\text { Inside Subcompartment } \\
\text { Structures }\end{array}$ \\
\hline 40 & Pressure Transducer & Seal Table Room & $\begin{array}{l}\text { Measure Gas Pressure } \\
\text { Inside Seal Table Room }\end{array}$ \\
\hline 41 & Aspirated Thermocouple & Level 3 & $\begin{array}{l}\text { Measure Gas } \\
\text { Temperature at Surtsey } \\
\text { Vessel Walls }\end{array}$ \\
\hline 42 & Aspirated Thermocouple & Level 3 & $\begin{array}{l}\text { Measure Gas } \\
\text { Temperature at Surtsey } \\
\text { Vessel Walls }\end{array}$ \\
\hline 43 & Aspirated Thermocouple & Level 1 & $\begin{array}{l}\text { Measure Gas } \\
\text { Temperature at Surtsey } \\
\text { Vessel Walls }\end{array}$ \\
\hline 44 & Aspirated Thermocouple & Level 1 & $\begin{array}{l}\text { Measure Gas } \\
\text { Temperature at Surtsey } \\
\text { Vessel Walls }\end{array}$ \\
\hline 45 & Aspirated Thermocouple & Level 1 & $\begin{array}{l}\text { Measure Gas } \\
\text { Temperature at Surtsey } \\
\text { Vessel Walls }\end{array}$ \\
\hline 46 & Aspirated Thermocouple & Level 5 & $\begin{array}{l}\text { Measure Gas } \\
\text { Temperature at Surtsey } \\
\text { Vessel Walls }\end{array}$ \\
\hline 47 & Aspirated Thermocouple & Level 5 & $\begin{array}{l}\text { Measure Gas } \\
\text { Temperature at Surtsey } \\
\text { Vessel Walls }\end{array}$ \\
\hline 48 & Aspirated Thermocouple & Level 5 & $\begin{array}{l}\text { Measure Gas } \\
\text { Temperature at Surtsey } \\
\text { Vessel Walls }\end{array}$ \\
\hline 49 & Aspirated Thermocouple & Level 3 & $\begin{array}{l}\text { Measure Gas } \\
\text { Temperature at Surtsey } \\
\text { Vessel Walls }\end{array}$ \\
\hline
\end{tabular}


Experiment Description

Table 2.1 IET inatrumentation location and purpoese (continued)

\begin{tabular}{|c|c|c|c|}
\hline $\begin{array}{l}\text { Channel } \\
\text { number }\end{array}$ & Instrument & Location & Purpose \\
\hline 50 & Ignitor & Crucible & $\begin{array}{l}\text { Timing Signal for } \\
\text { Thermite Ignition }\end{array}$ \\
\hline 51 & Aspirated Thermocouple & $\begin{array}{l}\text { Refueling Canal } \\
\text { Wall }\end{array}$ & $\begin{array}{l}\text { Measure Gas } \\
\text { Temperature Inside } \\
\text { Subcompartment } \\
\text { Structures }\end{array}$ \\
\hline 52 & Aspirated Thermocouple & $\begin{array}{l}\text { Refueling Canal } \\
\text { Wall }\end{array}$ & $\begin{array}{l}\text { Measure Gas } \\
\text { Temperature Inside } \\
\text { Subcompartment } \\
\text { Structures }\end{array}$ \\
\hline 53 & Aspirated Thermocouple & $\begin{array}{l}\text { Refueling Canal } \\
\text { Wall }\end{array}$ & $\begin{array}{l}\text { Measure Gas } \\
\text { Temperature Inside } \\
\text { Subcompartment } \\
\text { Structures }\end{array}$ \\
\hline 54 & Aspirated Thermocouple & Seal Table Room & $\begin{array}{l}\text { Measure Gas } \\
\text { Temperature Inside Seal } \\
\text { Table Room }\end{array}$ \\
\hline 55 & Aspirated Thermocouple & Seal Table Room & $\begin{array}{l}\text { Measure Gas } \\
\text { Temperature Inside Seal } \\
\text { Table Room }\end{array}$ \\
\hline 56 & Aspirated Thermocouple & Seal Table Room & $\begin{array}{l}\text { Measure Gas } \\
\text { Temperature Inside Seal } \\
\text { Table Room }\end{array}$ \\
\hline 57 & Thermocouple & Cavity Floor & $\begin{array}{l}\text { Measure Gas } \\
\text { Temperature Inside } \\
\text { Cavity }\end{array}$ \\
\hline 58 & Thermocouple & Crucible & $\begin{array}{l}\text { Measure Gas } \\
\text { Temperature Inside } \\
\text { Crucible }\end{array}$ \\
\hline 59 & Pressure Transducer & Coolant Pump 1A & $\begin{array}{l}\text { Measure Pressure } \\
\text { Caused by Heating } \\
\text { RCP 1A }\end{array}$ \\
\hline
\end{tabular}


Table 2.1 IET instrumentation location and purpose (continued)

\begin{tabular}{|c|c|c|c|}
\hline $\begin{array}{l}\text { Channel } \\
\text { number }\end{array}$ & Instrument & Locention & Purpose \\
\hline 62 & Pressure Transducer & Coolant Pump IB & $\begin{array}{l}\text { Measure Pressure } \\
\text { Caused by Heating } \\
\text { RCP 1B }\end{array}$ \\
\hline 63 & Pressure Transducer & Coolant Pump 1C & $\begin{array}{l}\text { Measure Pressure } \\
\text { Caused by Heating } \\
\text { RCP 1C }\end{array}$ \\
\hline 64 & Pressure Transducer & Coolant Pump 1D & $\begin{array}{l}\text { Measure Pressure } \\
\text { Caused by Heating } \\
\text { RCP 1D }\end{array}$ \\
\hline 65 & Pressure Transducer & Lower Head & $\begin{array}{l}\text { Measure Pressure Under } \\
\text { Containment Basement } \\
\text { Floor }\end{array}$ \\
\hline 66 & Thermocouple & Vent Space 1A & $\begin{array}{l}\text { Measure Gas } \\
\text { Temperature Above RCP } \\
\text { IA }\end{array}$ \\
\hline 67 & Thermocouple & Vent Space 1D & $\begin{array}{l}\text { Measure Gas } \\
\text { Temperature Above RCP } \\
\text { ID }\end{array}$ \\
\hline 68 & $\begin{array}{l}\text { Vessel Thermocouple } \\
\text { Array }\end{array}$ & Bottom & $\begin{array}{l}\text { Measure Local Gas } \\
\text { Temperature }\end{array}$ \\
\hline 69 & $\begin{array}{l}\text { Vessel Thermocouple } \\
\text { Array }\end{array}$ & & $\begin{array}{l}\text { Measure Local Gas } \\
\text { Temperature }\end{array}$ \\
\hline 70 & $\begin{array}{l}\text { Vessel Thermocouple } \\
\text { Array }\end{array}$ & & $\begin{array}{l}\text { Measure Local Gas } \\
\text { Temperature }\end{array}$ \\
\hline 71 & $\begin{array}{l}\text { Vessel Thermocouple } \\
\text { Array }\end{array}$ & & $\begin{array}{l}\text { Measure Local Gas } \\
\text { Temperature }\end{array}$ \\
\hline 72 & $\begin{array}{l}\text { Vessel Thermocouple } \\
\text { Array }\end{array}$ & & $\begin{array}{l}\text { Measure Local Gas } \\
\text { Temperature }\end{array}$ \\
\hline 73 & $\begin{array}{l}\text { Vessel Thermocouple } \\
\text { Array }\end{array}$ & & $\begin{array}{l}\text { Measure Local Gas } \\
\text { Temperature }\end{array}$ \\
\hline 74 & $\begin{array}{l}\text { Vessel Thermocouple } \\
\text { Array }\end{array}$ & & $\begin{array}{l}\text { Measure Local Gas } \\
\text { Temperature }\end{array}$ \\
\hline
\end{tabular}




\section{Experiment Description}

Table 2.1 IET instrumentation location and purpose (continued)

\begin{tabular}{|c|c|c|c|}
\hline $\begin{array}{l}\text { Channel } \\
\text { number }\end{array}$ & Instrument & Location & Purpose \\
\hline 75 & $\begin{array}{l}\text { Vessel Thermocouple } \\
\text { Array }\end{array}$ & & $\begin{array}{l}\text { Measure Local Gas } \\
\text { Temperature }\end{array}$ \\
\hline 76 & $\begin{array}{l}\text { Vessel Thermocouple } \\
\text { Array }\end{array}$ & & $\begin{array}{l}\text { Measure Local Gas } \\
\text { Temperature }\end{array}$ \\
\hline 77 & $\begin{array}{l}\text { Vessel Thermocouple } \\
\text { Array }\end{array}$ & Top & $\begin{array}{l}\text { Measure Local Gas } \\
\text { Temperature }\end{array}$ \\
\hline 80 & Pressure Transducer & Level 5 & $\begin{array}{l}\text { Measure Gas Pressure } \\
\text { in Surtsey Upper Dome }\end{array}$ \\
\hline 81 & Thermocouple & Accumulator & $\begin{array}{l}\text { Measure Gas } \\
\text { Temperature } \\
0.32 \mathrm{~cm} \text { From Inner } \\
\text { Wall }\end{array}$ \\
\hline 82 & Thermocouple & Accumulator & $\begin{array}{l}\text { Measure Gas } \\
\text { Temperature } \\
0.32 \mathrm{~cm} \text { From Inner } \\
\text { Wall }\end{array}$ \\
\hline 83 & Thermocouple & Accumulator & $\begin{array}{l}\text { Measure Gas } \\
\text { Temperature } \\
0.32 \mathrm{~cm} \text { From Inner } \\
\text { Wall }\end{array}$ \\
\hline 84 & Thermocouple & Accumulator & $\begin{array}{l}\text { Measure Gas } \\
\text { Temperature } \\
0.32 \mathrm{~cm} \text { From Inner } \\
\text { Wall }\end{array}$ \\
\hline 85 & Thermocouple & Accumulator & $\begin{array}{l}\text { Measure Gas } \\
\text { Temperature } \\
0.32 \mathrm{~cm} \text { From Inner } \\
\text { Wall }\end{array}$ \\
\hline 86 & Thermocouple & Accumulator & $\begin{array}{l}\text { Measure Gas } \\
\text { Temperature } \\
0.32 \mathrm{~cm} \text { From Inner } \\
\text { Wall }\end{array}$ \\
\hline 87 & Thermocouple & Accumulator & $\begin{array}{l}\text { Measure Flange Outside } \\
\text { Surface Temperature }\end{array}$ \\
\hline
\end{tabular}


Table 2.1 JET instrumentation location and purpose (continued)

\begin{tabular}{|c|c|c|c|}
\hline $\begin{array}{l}\text { Channel } \\
\text { number }\end{array}$ & Instrument & Location & Purpose \\
\hline 88 & Thermocouple & Accumulator & $\begin{array}{l}\text { Measure Accumulator } \\
\text { Outside Surface } \\
\text { Temperature }\end{array}$ \\
\hline 90 & Thermocouple & Accumulator & $\begin{array}{l}\text { Measure Accumulator } \\
\text { Outside Surface } \\
\text { Temperature }\end{array}$ \\
\hline 91 & Thermocouple & Accumulator & $\begin{array}{l}\text { Measure Gas } \\
\text { Temperature Inside } \\
\text { Accumulator Tank }\end{array}$ \\
\hline 92 & Thermocouple & Accumulator & $\begin{array}{l}\text { Measure Gas } \\
\text { Temperature Inside } \\
\text { Accumulator Tank }\end{array}$ \\
\hline 93 & Thermocouple & $\begin{array}{l}\text { 10.2-cm Pipe } \\
\text { Between } \\
\text { Accumulator and } \\
\text { Melt Generator }\end{array}$ & $\begin{array}{l}\text { Measure Gas } \\
\text { Temperature Inside Pipe } \\
\text { with Burst Diaphragm }\end{array}$ \\
\hline 98 & Thermocouple & Vent Space 1B & $\begin{array}{l}\text { Measure Gas } \\
\text { Temperature Above RCP } \\
\text { IB }\end{array}$ \\
\hline 99 & Thermocouple & Vent Space 1C & $\begin{array}{l}\text { Measure Gas } \\
\text { Temperature Above RCP } \\
\text { 1C }\end{array}$ \\
\hline 103 & Thermocouple & $\begin{array}{l}10.2 \mathrm{~cm} \text { Pipe Elbow } \\
\text { Between Melt } \\
\text { Generator and } \\
\text { Crucible }\end{array}$ & $\begin{array}{l}\text { Measure Skin } \\
\text { Temperature }\end{array}$ \\
\hline P1 & $\begin{array}{l}\text { Piezoelectric Pressure } \\
\text { Transducer }\end{array}$ & East Side of Cavity & $\begin{array}{l}\text { Measure Pressure in } \\
\text { Cavity Wall Under the } \\
\text { Melt Generator }\end{array}$ \\
\hline $\mathbf{P 2}$ & $\begin{array}{l}\text { Piezoelectric Pressure } \\
\text { Transducer }\end{array}$ & West Side of Cavity & $\begin{array}{l}\text { Measure Pressure in } \\
\text { Cavity Wall Under the } \\
\text { Melt Generator }\end{array}$ \\
\hline
\end{tabular}


Experiment Description

Table 2.1 IET instrumentation location and purpose (concluded)

\begin{tabular}{|c|c|c|c|}
\hline $\begin{array}{l}\text { Channel } \\
\text { number }\end{array}$ & Instrument & Location & Purpose \\
\hline P3 & $\begin{array}{l}\text { Piezoelectric Pressure } \\
\text { Transducer }\end{array}$ & Crane Wall & $\begin{array}{l}\text { Measure Gas Pressure } \\
\text { Inside Subcompartment } \\
\text { Structures }\end{array}$ \\
\hline P4 & $\begin{array}{l}\text { Piezoelectric Pressure } \\
\text { Transducer }\end{array}$ & Refueling Canal & $\begin{array}{l}\text { Measure Gas Pressure } \\
\text { Inside Subcompartment } \\
\text { Structures }\end{array}$ \\
\hline $\mathrm{L} 2$ & Gas Grab Sample & Surtsey Level 2 & $\begin{array}{l}\text { Measure Gas } \\
\text { Composition Prior to and } \\
\text { After HPME }\end{array}$ \\
\hline L4 & Gas Grab Sample & Surtsey Level 4 & $\begin{array}{l}\text { Measure Gas } \\
\text { Composition Prior } \\
\text { to and After HPME }\end{array}$ \\
\hline L6 & Gas Grab Sample & Surtsey Level 6 & $\begin{array}{l}\text { Measure Gas } \\
\text { Composition Prior to and } \\
\text { After HPME }\end{array}$ \\
\hline C & Gas Grab Sample & Cavity & $\begin{array}{l}\text { Measure Gas } \\
\text { Composition Prior to and } \\
\text { After HPME }\end{array}$ \\
\hline B & Gas Grab Sample & $\begin{array}{l}\text { Subcompartment } \\
\text { Structure }\end{array}$ & $\begin{array}{l}\text { Measure Gas } \\
\text { Composition Prior to and } \\
\text { After HPME }\end{array}$ \\
\hline
\end{tabular}


Experiment Description

Table 2.2 Target conditions for counterpart experiments as designed

\begin{tabular}{|c|c|c|}
\hline Initial condition & $\begin{array}{c}\text { ZION } \\
\text { Pump seal LOCA }\end{array}$ & SNL/IET \\
\hline GEOMETRY & Zion & Zion \\
\hline $\begin{array}{c}\text { MELT OR MELT SIMUL } \\
\text { Material } \\
\text { Mass (kg) } \\
\text { Temnerature (K) }\end{array}$ & $\begin{array}{c}\text { Corium } \\
54 \times 10^{3} \\
2500\end{array}$ & $\begin{array}{l}\text { Thermite } \\
43 \\
{\left[43 \times 10^{3}\right]} \\
2375\end{array}$ \\
\hline $\begin{array}{c}\text { RCS OR ACCUMULATC } \\
\text { Driving Gas } \\
\text { Pressure (MPa) } \\
\text { Temperature (K) } \\
\text { Moles of Driving Gas }\end{array}$ & $\begin{array}{c}\text { Steam } \\
6.2 \\
700 \\
4.00 \times 10^{5}\end{array}$ & $\begin{array}{l}\text { Steam } \\
6.2 \\
600 \\
425 \\
{\left[4.2 \times 10^{5}\right]}\end{array}$ \\
\hline $\begin{array}{l}\text { CAVITY WATER } \\
\text { (Mass kg) }\end{array}$ & 2600 & $\begin{array}{c}3.48 \\
{[3480]}\end{array}$ \\
\hline $\begin{array}{c}\text { CONTAINMENT } \\
\text { ATMOSPHERE } \\
\text { Constituents } \\
\text { Pressure (MPa) } \\
\text { Temperature (K) } \\
\text { Moles }\end{array}$ & $\begin{array}{l}\text { Air } / \text { Steam } / \mathrm{H}_{2} \\
0.20 \\
373 \\
4.95 \times 10^{6}\end{array}$ & $\begin{array}{c}\text { Nitrogen } \\
\text { Air/Nitrogen } \\
0.20 \\
298 \\
7193 \\
{\left[7.19 \times 10^{\circ}\right]}\end{array}$ \\
\hline a $-5+5+2$ & valent. & \\
\hline
\end{tabular}


Experiment Description

Table 2.3 Geometric parameters for counterpart experiments as designed

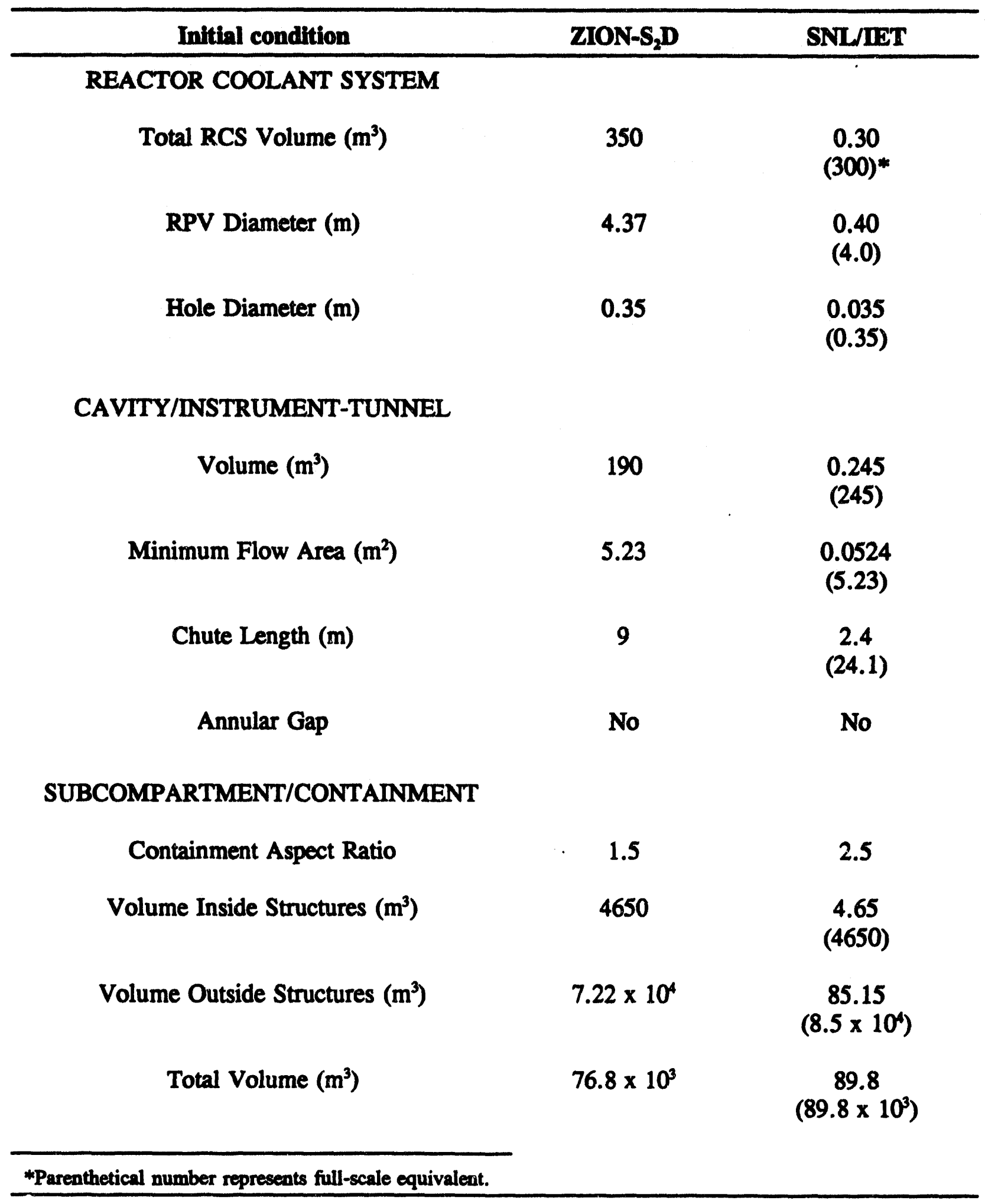


Table 2.4 Melt composition

\begin{tabular}{ccccccc}
\hline & \multicolumn{2}{c}{ Mass fraction } & \multicolumn{2}{c}{ Mole fraction } & \multicolumn{2}{c}{ Volume fraction } \\
\cline { 2 - 7 } Constituent & Corium & Thermite & Corium & Thermite & Corium & Thermite \\
\hline $\mathrm{UO}_{2}$ & 0.6100 & 0.0000 & 0.2745 & 0.0000 & 0.5166 & 0.0000 \\
$\mathrm{ZrO}_{2}$ & 0.0000 & 0.0000 & 0.0000 & 0.0000 & 0.0000 & 0.0000 \\
$\mathrm{Zr}$ & 0.1500 & 0.0000 & 0.2003 & 0.0000 & 0.1987 & 0.0000 \\
$\mathrm{Fe}$ & 0.1730 & 0.5200 & 0.3753 & 0.5860 & 0.2049 & 0.3326 \\
$\mathrm{Cr}$ & 0.0430 & 0.1100 & 0.1005 & 0.1335 & 0.0548 & 0.0758 \\
$\mathrm{Ni}$ & 0.0240 & 0.0000 & 0.0494 & 0.0000 & 0.0250 & 0.0000 \\
$\mathrm{Al}_{2} \mathrm{O}_{3}$ & 0.0000 & 0.3400 & 0.0000 & 0.2104 & 0.0000 & 0.5235 \\
$\mathrm{A1}$ & 0.0000 & 0.0300 & 0.0000 & 0.0701 & 0.0000 & 0.0681 \\
\hline
\end{tabular}

Table 2.5 Material properties of the melt

\begin{tabular}{ccc}
\hline Property & Corium & Thermite \\
\hline $\begin{array}{c}\mathrm{C}_{\mathrm{p}} \\
(\mathrm{J} / \mathrm{mole} / \mathrm{K})\end{array}$ & 67.5 & 70.8 \\
$\begin{array}{c}\mathrm{C}_{\mathrm{p}} \\
(\mathrm{J} / \mathrm{kg} / \mathrm{K})\end{array}$ & 556 & 1121 \\
$\begin{array}{c}\mathrm{K} \\
(\mathrm{W} / \mathrm{m} / \mathrm{K})\end{array}$ & 14.1 & 25.3 \\
$\begin{array}{c}\rho \\
\left(\mathrm{kg} / \mathrm{m}^{3}\right)\end{array}$ & 7698 & 5157 \\
$\begin{array}{c}\rho \\
\left(\mathrm{mole} / \mathrm{m}^{3}\right)\end{array}$ & $6.33 \times 10^{4}$ & $6.59 \times 10^{4}$ \\
$\begin{array}{c}\mu \\
(\mathrm{Pa} \mathrm{s})\end{array}$ & $7.59 \times 10^{-3}$ & $5.63 \times 10^{-3}$ \\
$\begin{array}{c}\sigma \\
(\mathrm{N} / \mathrm{m})\end{array}$ & 0.973 & 0.932 \\
$\begin{array}{c}\mathrm{T}_{\mathrm{mp}} \\
(\mathrm{K})\end{array}$ & 2450 & 2300 \\
$\begin{array}{c}\mathrm{MW} \\
(\mathrm{kg} / \mathrm{mole})\end{array}$ & 0.1215 & 0.0631 \\
\hline
\end{tabular}


Experiment Description

Table 2.6 Equilibrium models for estimating containment pressurization

\begin{tabular}{ccc}
\hline $\begin{array}{c}\text { Modeling } \\
\text { parameter }\end{array}$ & Zion-S $_{2} \mathrm{D}$ & $\begin{array}{c}\text { SNL/IET-1 } \\
1: 10 \text { scale }\end{array}$ \\
\hline $\mathrm{Nd}$ & $4.42 \times 10^{5}$ & 667 \\
$\mathrm{C}_{\mathrm{d}}$ & 67.5 & 70.8 \\
$\mathrm{~N}^{\mathrm{0}}$ & $4.95 \times 10^{6}$ & $7.19 \times 10^{3}$ \\
$\mathrm{~N}_{\mathrm{b}}$ & $4.74 \times 10^{5}$ & 392 \\
$\mathrm{C}_{\mathrm{v}}$ & 28.3 & 24.1 \\
$\mathrm{U}^{0}$ & $5.22 \times 10^{10}$ & $5.17 \times 10^{7}$ \\
$\Delta \mathrm{E}_{\mathrm{b}}$ & $6.36 \times 10^{9}$ & $5.27 \times 10^{6}$ \\
$\Delta \mathrm{e}_{\mathrm{t}}$ & $1.55 \times 10^{5}$ & $1.47 \times 10^{5}$ \\
$\Delta \mathrm{e}_{\mathrm{v}}$ & $1.41 \times 10^{5}$ & $5.66 \times 10^{4}$ \\
$\psi$ & 0.193 & 0.257 \\
$\Delta \mathrm{P} / \mathrm{P}^{0} 1-\mathrm{cell}$ & 2.21 & 2.17 \\
$\mathrm{~N}_{\mathrm{w}}$ & $1.44 \times 10^{5}$ & 193 \\
$\Delta \mathrm{e}_{\mathrm{w}}$ & $3.96 \times 10^{4}$ & $3.96 \times 10^{4}$ \\
$\Delta \mathrm{P}_{\mathrm{w}} / \mathrm{P}^{\mathrm{O}}$ & 0.092 & 0.117 \\
\hline
\end{tabular}

Table 2.7 Fractional contribution to containment pressurization

\begin{tabular}{lccc}
\hline Contributor & Zion-S 2 D & $\begin{array}{c}\text { SNL/IET-1 } \\
1: 10 \text { scale }\end{array}$ & $\begin{array}{c}\text { ANL/IET-1 } \\
\text { 1:40 scale }\end{array}$ \\
\hline Blowdown & 0.046 & 0.037 & 0.046 \\
Thermal & 0.500 & 0.698 & 0.684 \\
Oxidation & 0.454 & 0.265 & 0.270 \\
\hline
\end{tabular}


Experiment Description

Table 2.8 Atmosphere composition for Zion containment

\begin{tabular}{|c|c|c|c|c|}
\hline $\mathbf{f}_{\mathbf{z r}}$ & $\mathbf{x}_{\mathrm{B2}}$ & $\mathbf{X}_{\mathrm{sm}}$ & $\mathbf{x}_{\text {Am }}$ & Source \\
\hline 0.17 & 0.015 & 0.492 & 0.492 & $\begin{array}{l}\text { NUREG-1150 } \\
5 \% \text { confidence }\end{array}$ \\
\hline $4=$ & 101968 & 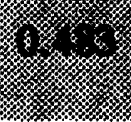 & 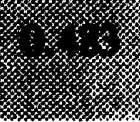 & 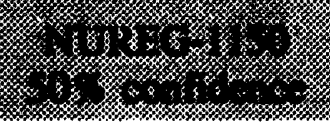 \\
\hline 0.64 & 0.054 & 0.473 & 0.473 & $\begin{array}{l}\text { NUREG-1150 } \\
95 \% \text { confidence }\end{array}$ \\
\hline 0.47 & 0.042 & 0.479 & 0.479 & NUREG/CR-4624 \\
\hline
\end{tabular}

Note: Shaded box is design basis for counterpart test. 


\section{Experiment Description}

Table 2.9 Initial conditions for the IET experiments

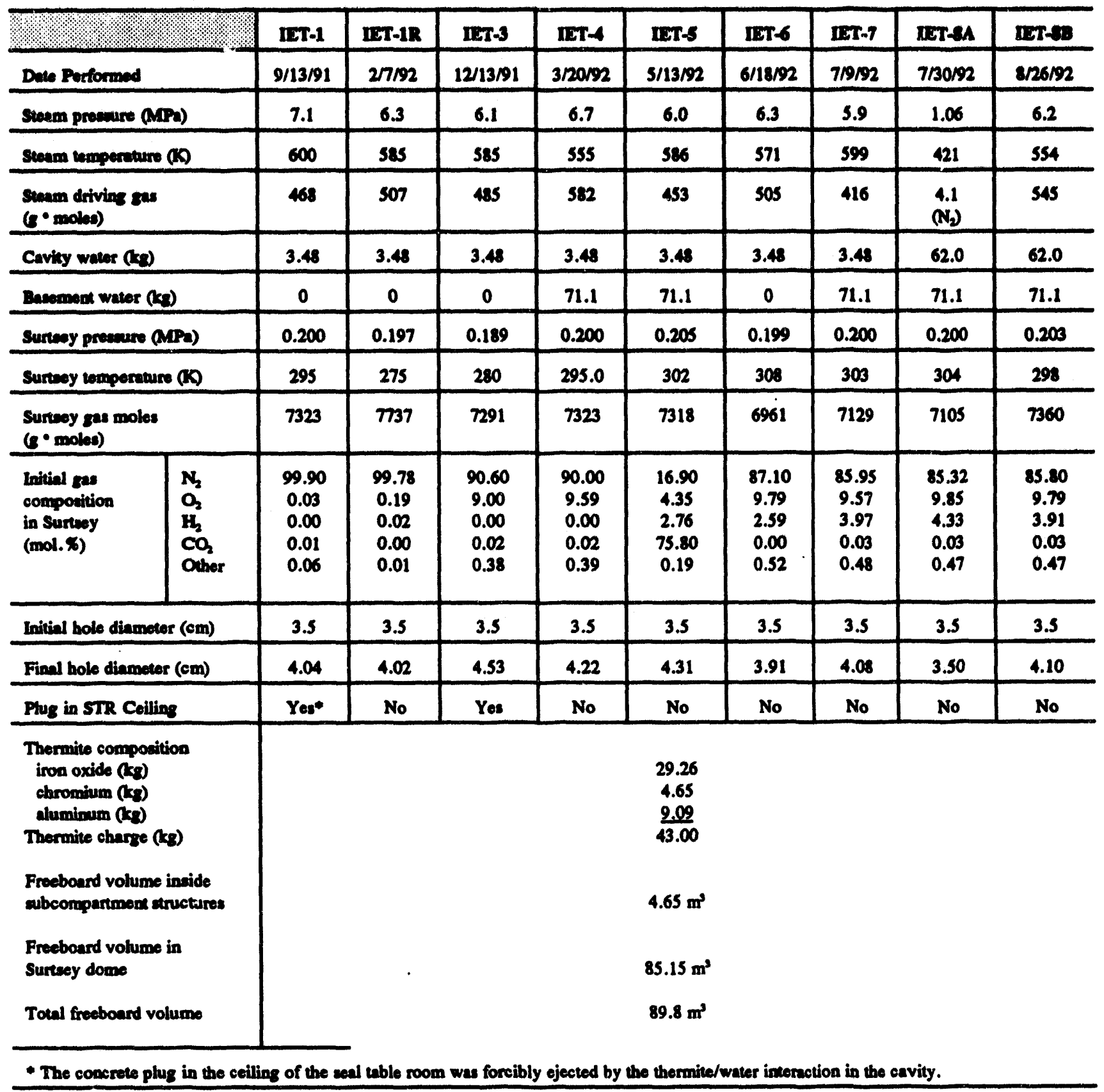


Experiment Description

Table 2.10 Inttial conditions for the IET-2A, IET-2B, and IET-2C expertments

\begin{tabular}{|c|c|c|c|}
\hline 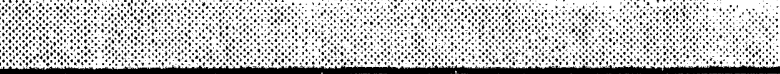 & IET-2A & IET-2B & IET-2C \\
\hline Date Performed & $11 / 1 . / 91$ & $4 / 28 / 92$ & $5 / 1 / 92$ \\
\hline $\begin{array}{l}\text { Thermite composition }(\mathrm{kg}) \\
\text { iron oxide } \\
\text { chromium } \\
\text { aluminum } \\
\text { Mass of the initial thermite charge }(\mathrm{kg})\end{array}$ & $\begin{array}{r}29.26 \\
4.65 \\
2.09 \\
43.00\end{array}$ & $\begin{array}{r}29.26 \\
4.65 \\
2.09 \\
43.00\end{array}$ & $\begin{array}{r}29.26 \\
4.65 \\
2.09 \\
43.00\end{array}$ \\
\hline $\begin{array}{l}\text { Hole diameter (cm) } \\
\text { initial } \\
\text { final }\end{array}$ & $\begin{array}{c}3.5 \\
4.04\end{array}$ & $\begin{array}{c}3.5 \\
4.01\end{array}$ & $\begin{array}{l}10.0 \\
8.86^{\circ}\end{array}$ \\
\hline Steam pressure at plug failure (MPa) & 6.1 & 5.8 & N/A \\
\hline Steam temperature at plug failure (K) & 588 & 588 & N/A \\
\hline Moles of steam driving gas (moles) & 464 & 418 & N/A \\
\hline $\begin{array}{l}\text { * The final hole diameter was amaller than the initi } \\
\text { out of the hole in the graphite limitor plate since } \\
\text { large bole. }\end{array}$ & A. & ot all & $\begin{array}{l}\text { plug me } \\
\text { ratively }\end{array}$ \\
\hline
\end{tabular}


Table 2.11 IET-2 instrumentation location and purpose

\begin{tabular}{|c|c|c|c|}
\hline $\begin{array}{l}\text { Chnnued } \\
\text { number }\end{array}$ & Instrument & Locention & Purpose \\
\hline 12 & Type-C Thermocouple & Cavity & $\begin{array}{l}\text { Measure Temperature } \\
\text { Inside Cavity }\end{array}$ \\
\hline 14 & Type-C Thermocouple & Crucible & $\begin{array}{l}\text { Messure Thermite } \\
\text { Temperature }\end{array}$ \\
\hline 16 & Two-color Pyrometer & Crucible Exit & $\begin{array}{l}\text { Measure Debris } \\
\text { Temperature as it Exited } \\
\text { Crucible - West Side }\end{array}$ \\
\hline 17 & Photodiode & Crucible Plug & HPME Timing \\
\hline 18 & Photodiode & Crucible Plug & HPME Timing \\
\hline 32 & Pressure Transducer & Accumulator & $\begin{array}{l}\text { Measure Gas Pressure in } \\
\text { Accumulator Tank }\end{array}$ \\
\hline 33 & Pressure Transducer & Burst Diaphragm & Measure Gas Pressure \\
\hline 34 & Pressure Transducer & Crucible & Measuire Gas Pressure \\
\hline 35 & Pressure Transducer & Crucible & Measure Gas Pressure \\
\hline 36 & Pressure Transducer & Cavity & $\begin{array}{l}\text { Measure Gas Pressure in } \\
\text { the Cavity }\end{array}$ \\
\hline 37 & Pressure Transducer & Cavity & $\begin{array}{l}\text { Measure Gas Pressure in } \\
\text { the Cavity }\end{array}$ \\
\hline 38 & $\begin{array}{l}\text { Optical Pyrometer } \\
\text { Type } 11 \times 30\end{array}$ & Crucible Exit & $\begin{array}{l}\text { Measure Debris } \\
\text { Temperature as it Exited } \\
\text { Crucible - Bottom }\end{array}$ \\
\hline 39 & $\begin{array}{l}\text { Optical Pyrometer } \\
\text { Type } 11 \times 30\end{array}$ & Crucible Exit & $\begin{array}{l}\text { Measure Debris } \\
\text { Temperature as it Exited } \\
\text { Crucible - East Side }\end{array}$ \\
\hline 50 & Type-K Thermocouple & 4" Pipe Over Crucible & $\begin{array}{l}\text { Measure Gas Temperature } \\
\text { Above Crucible }\end{array}$ \\
\hline 55 & Type-K Thermocouple & $\begin{array}{l}\text { Cavity North Gas } \\
\text { Vent }\end{array}$ & $\begin{array}{l}\text { Measure Gas Temperature } \\
\text { Exiting Cavity }\end{array}$ \\
\hline 56 & Type-K Thermocouple & Cavity South Gas Vent & $\begin{array}{l}\text { Measure Gas Temperature } \\
\text { Exiting Cavity }\end{array}$ \\
\hline 71 & Ignitor & Thermite Burn Time & Thermite Ignitor \\
\hline $\mathbf{N} / \mathbf{A}$ & Camera - $16 \mathrm{~mm}$ & Crucible Exit - East & View Exit Stream \\
\hline $\mathbf{N} / \mathbf{A}$ & Camera - $16 \mathrm{~mm}$ & Crucible Exit - West & View Exit Stream \\
\hline N/A & Camera - VHS & Cavity Exit - South & View Experiment \\
\hline
\end{tabular}




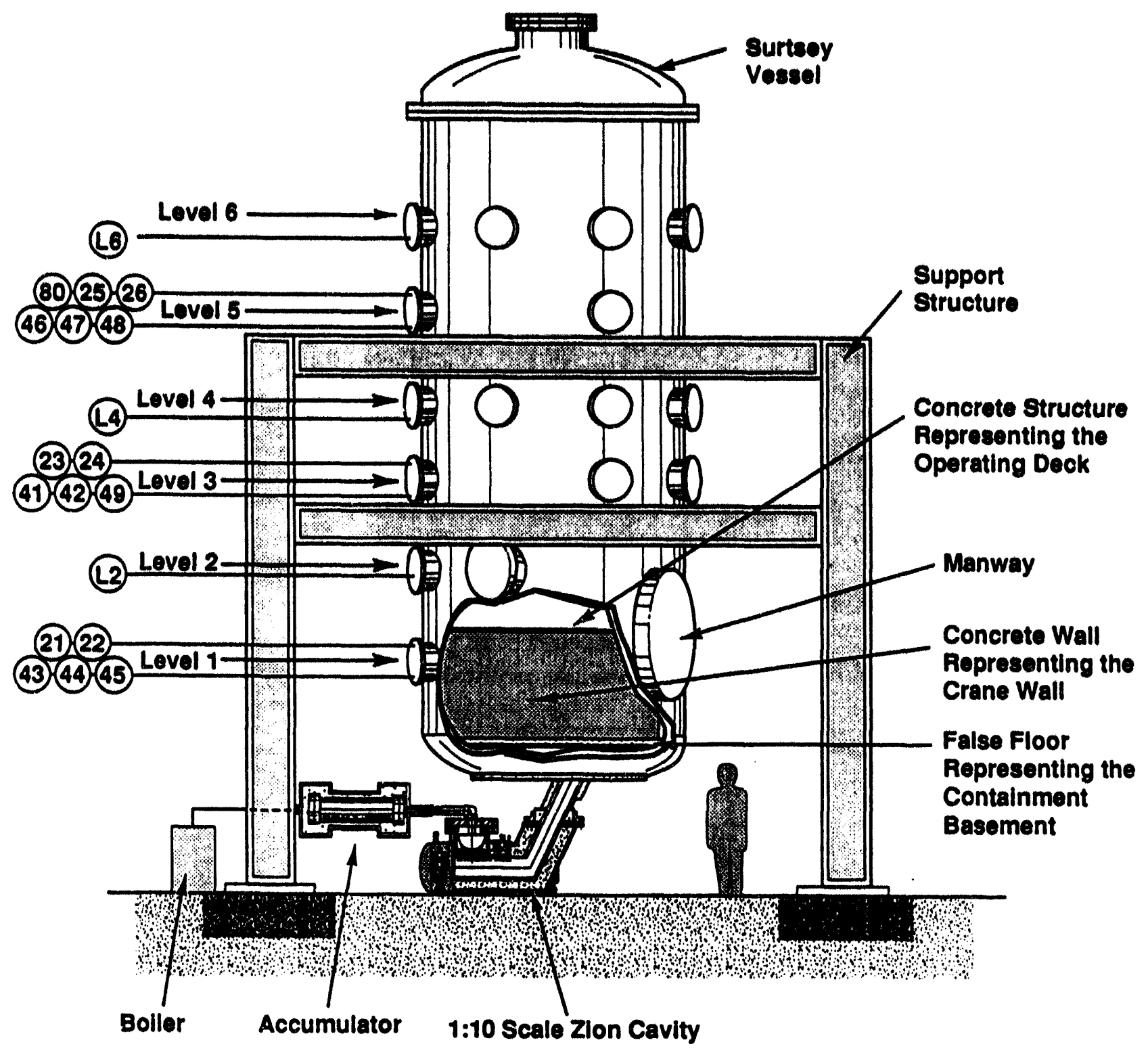

Note: All pressure transducers have Individual penotrations.

Figure 2.1 Surtsey vessel, high-pressure melt ejection system, and subcompartment structures used in the IET experiments 


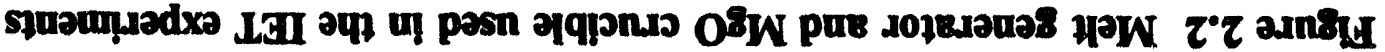

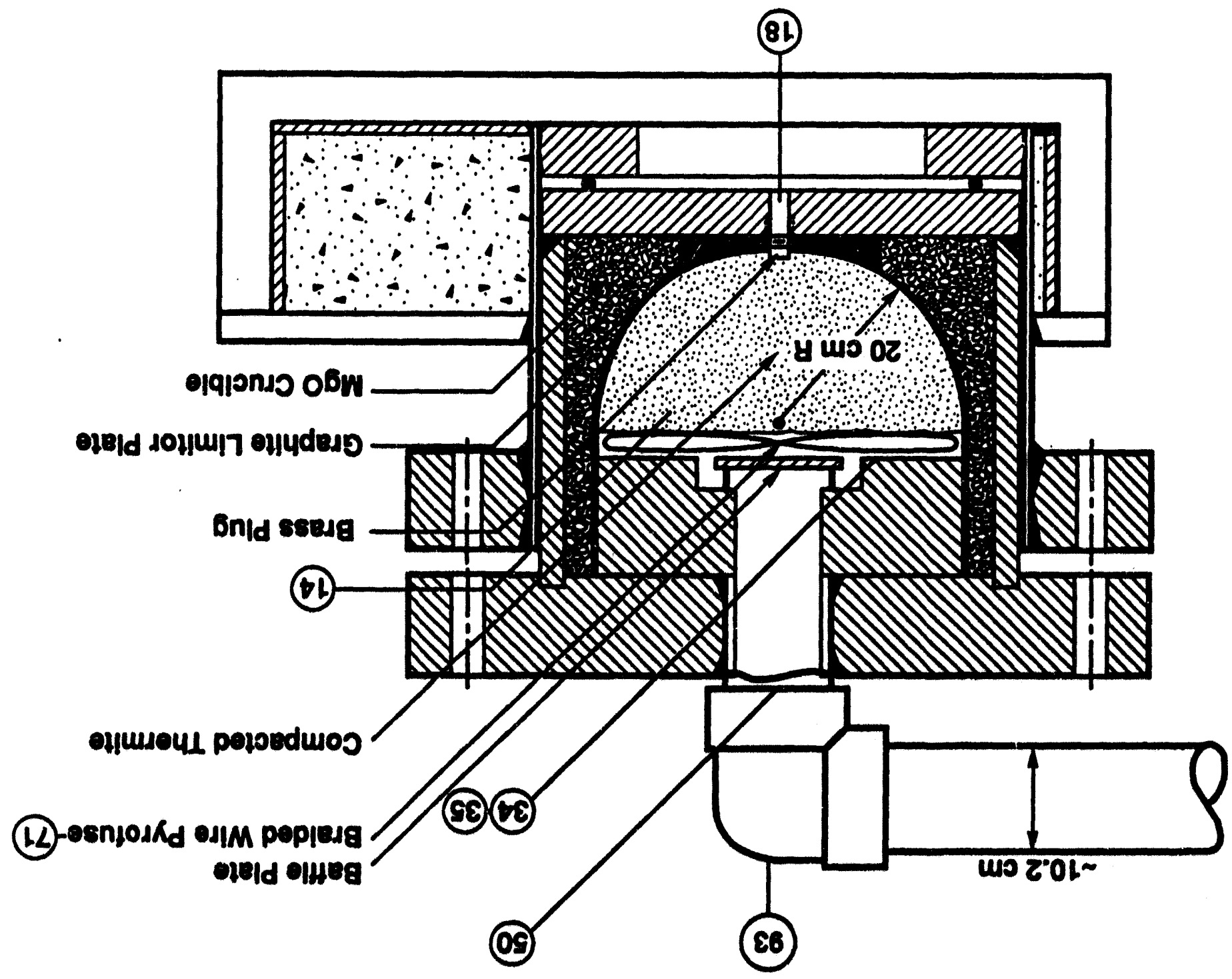




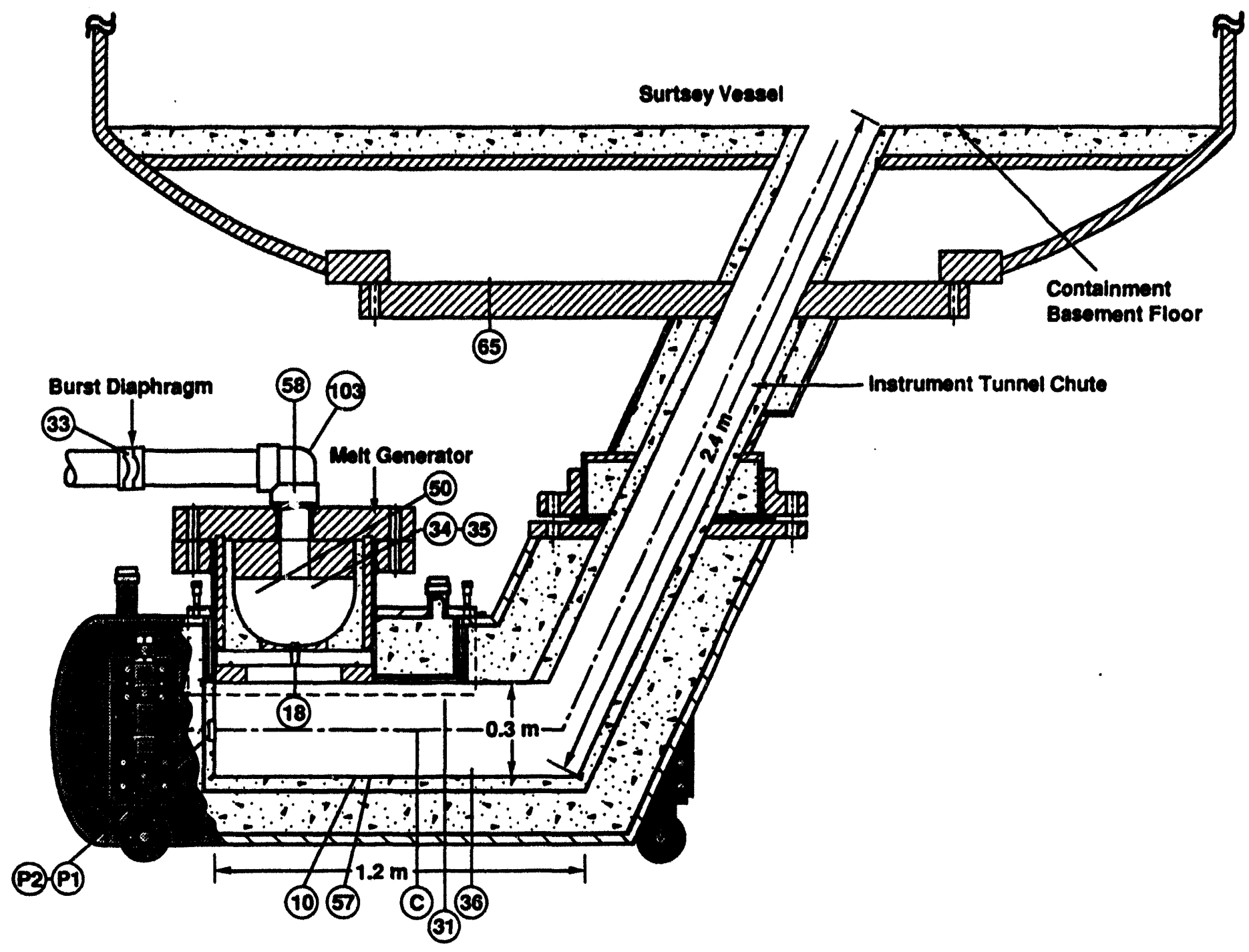

Figure 2.3 Schematic of the 1:10 linear scale model of the Zion reactor cavity 


\section{Experiment Description}

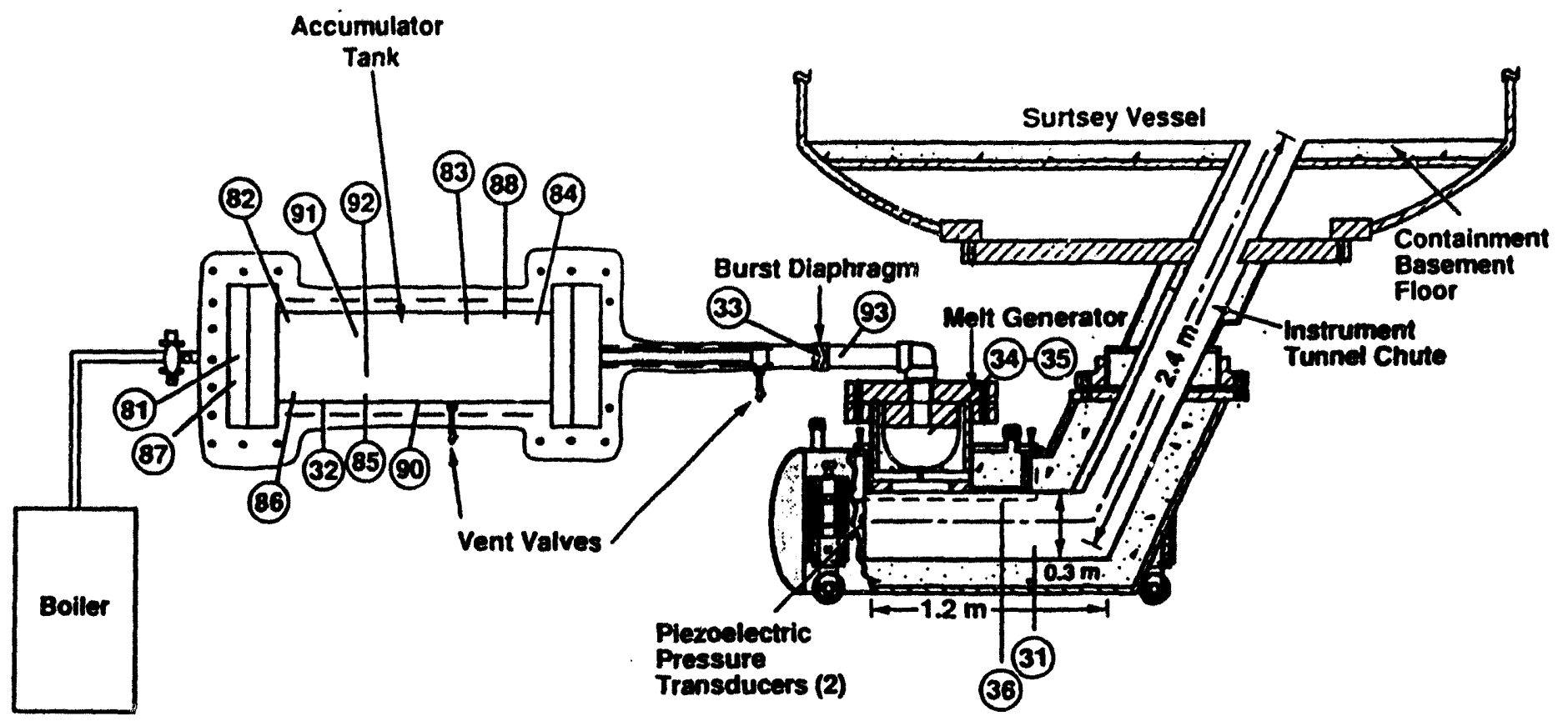

Figure 2.4 High-pressure steam boiler, steam accumulator, melt generator, cavity, and Surtsey vessel layout used in the IET experiments 


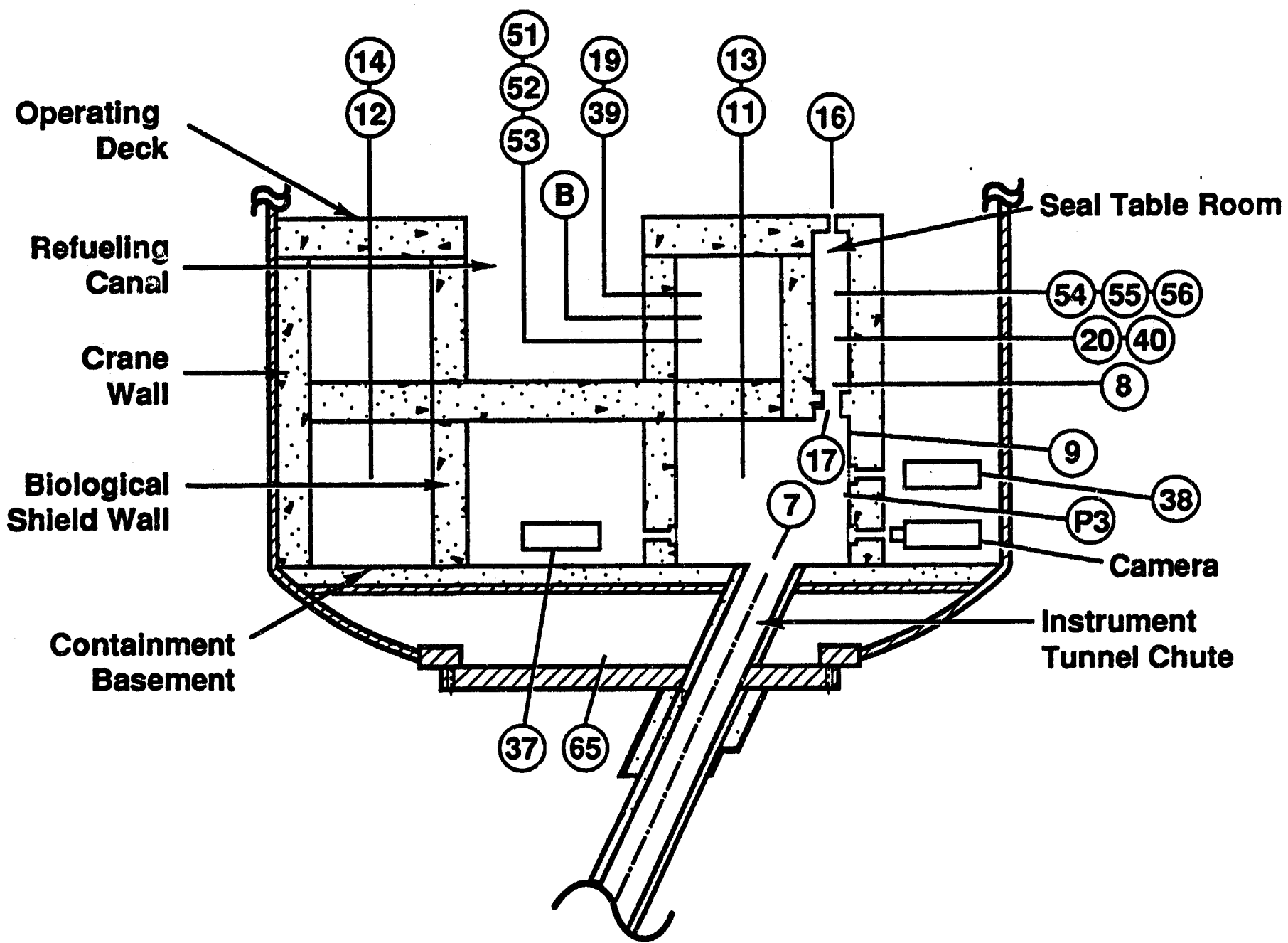

Figure 2.5 Two-dimensional view of the subcompartment structures inside the Surtsey vessel 


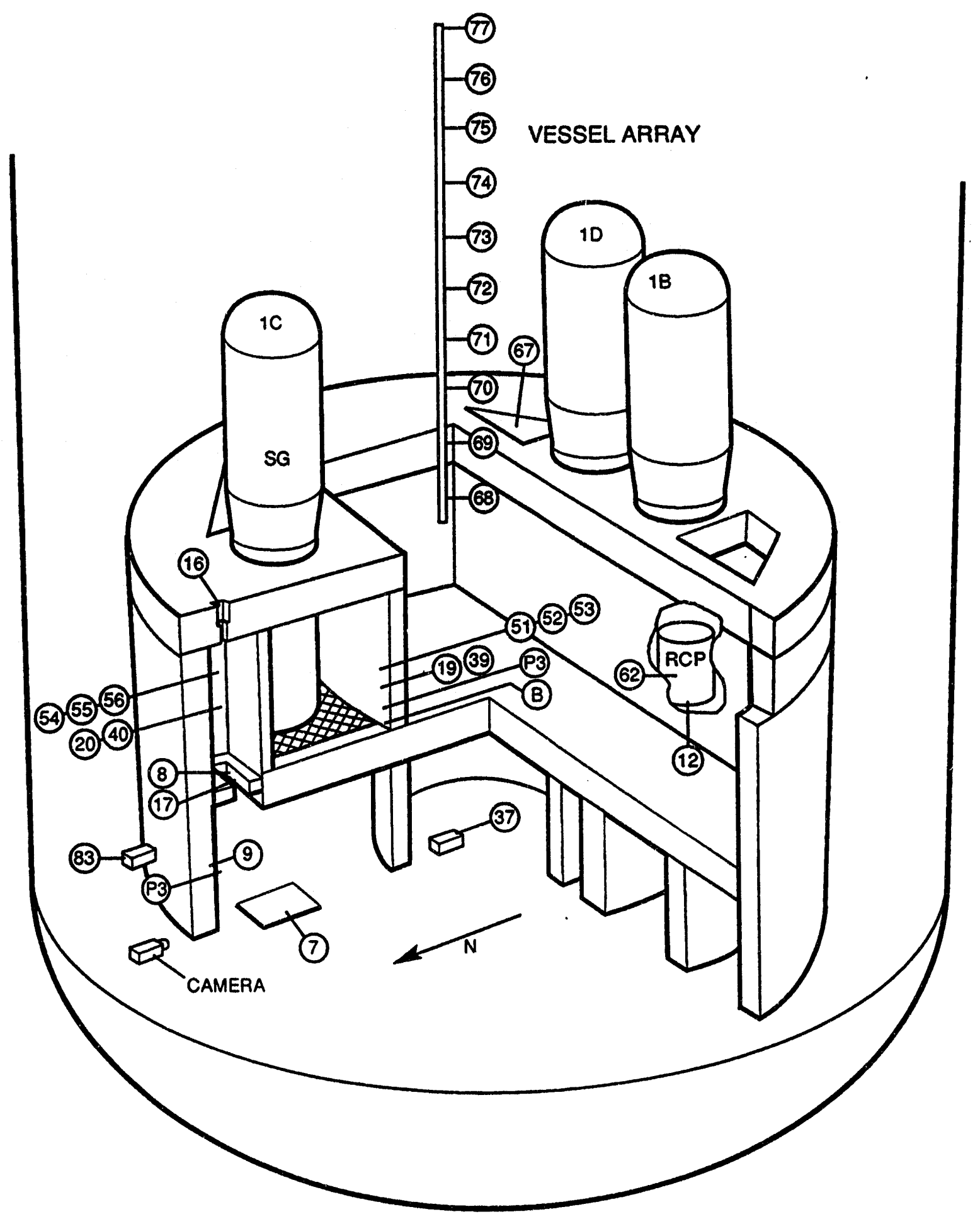

Figure 2.6 Isometric view of the subcompartment structures inside the Surtsey vessel 


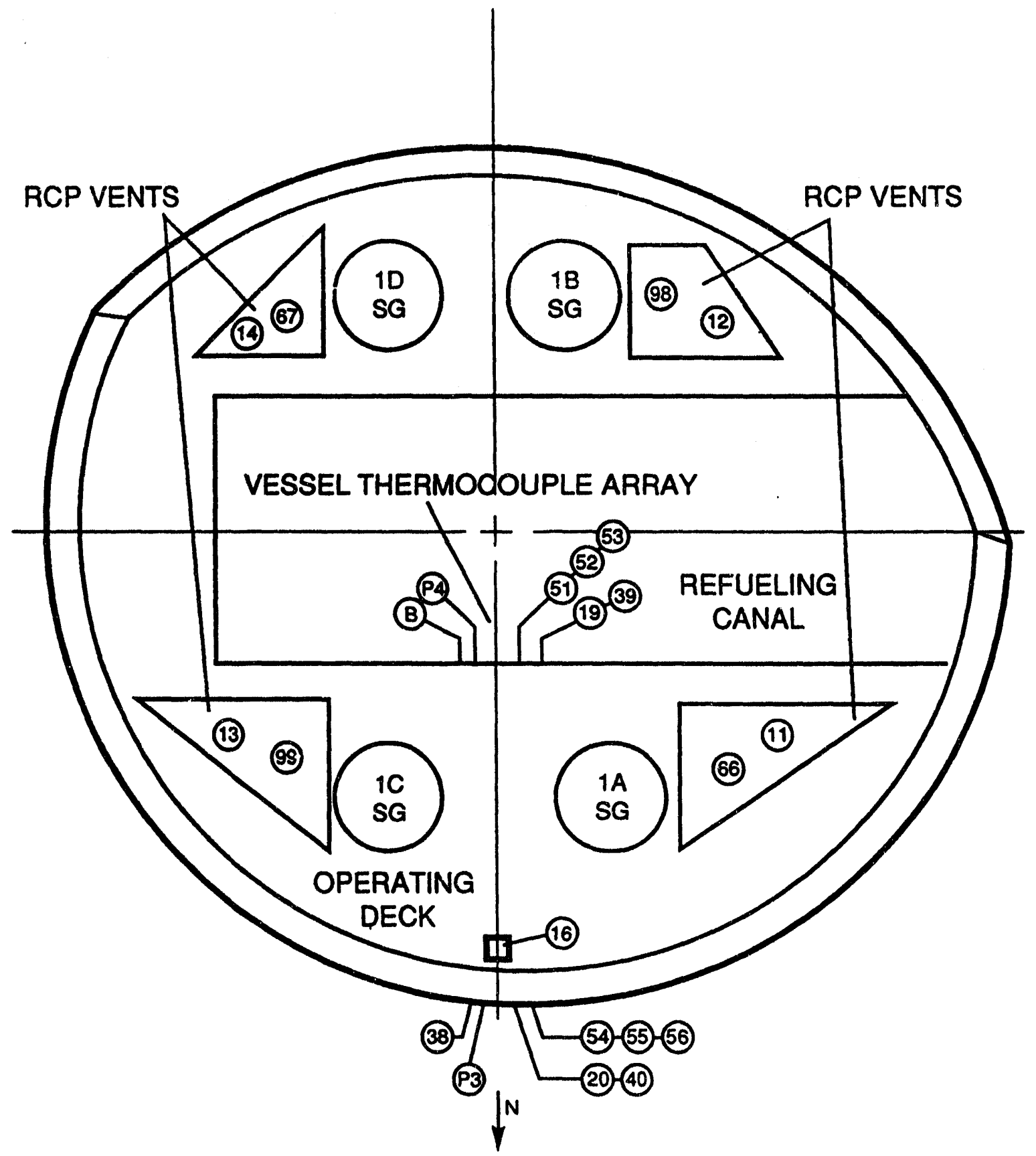

Figure 2.7 Top view of structures inside the Surtsey vessel 
Experiment Description

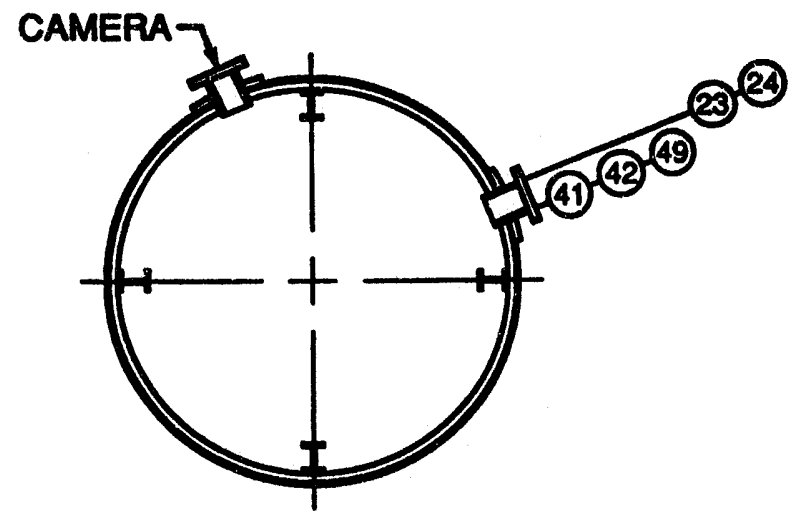

LEVEL 3
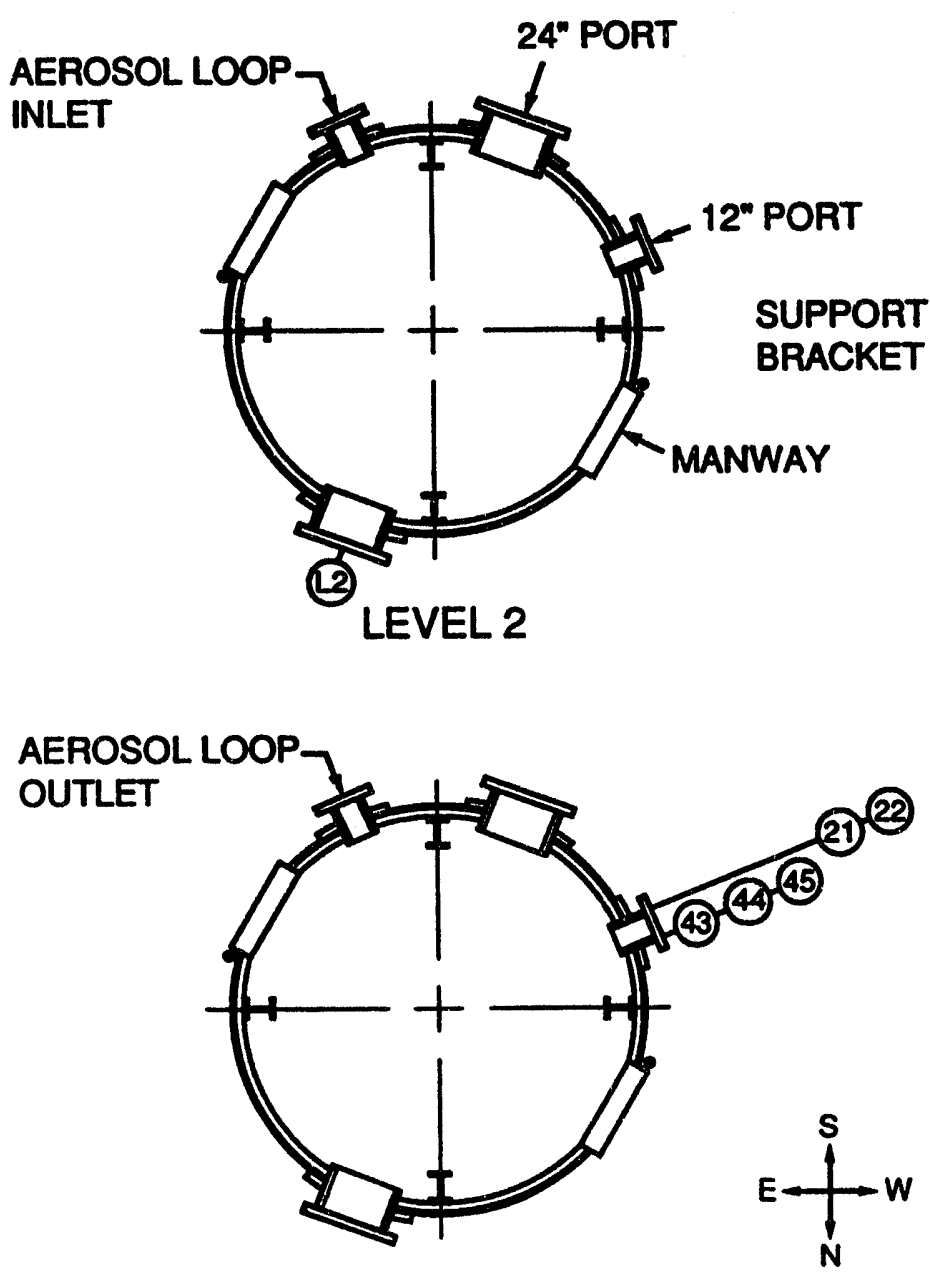

LEVEL 1

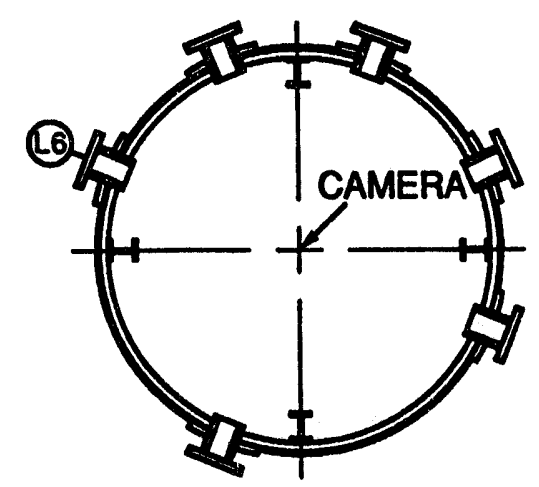

LEVEL 6
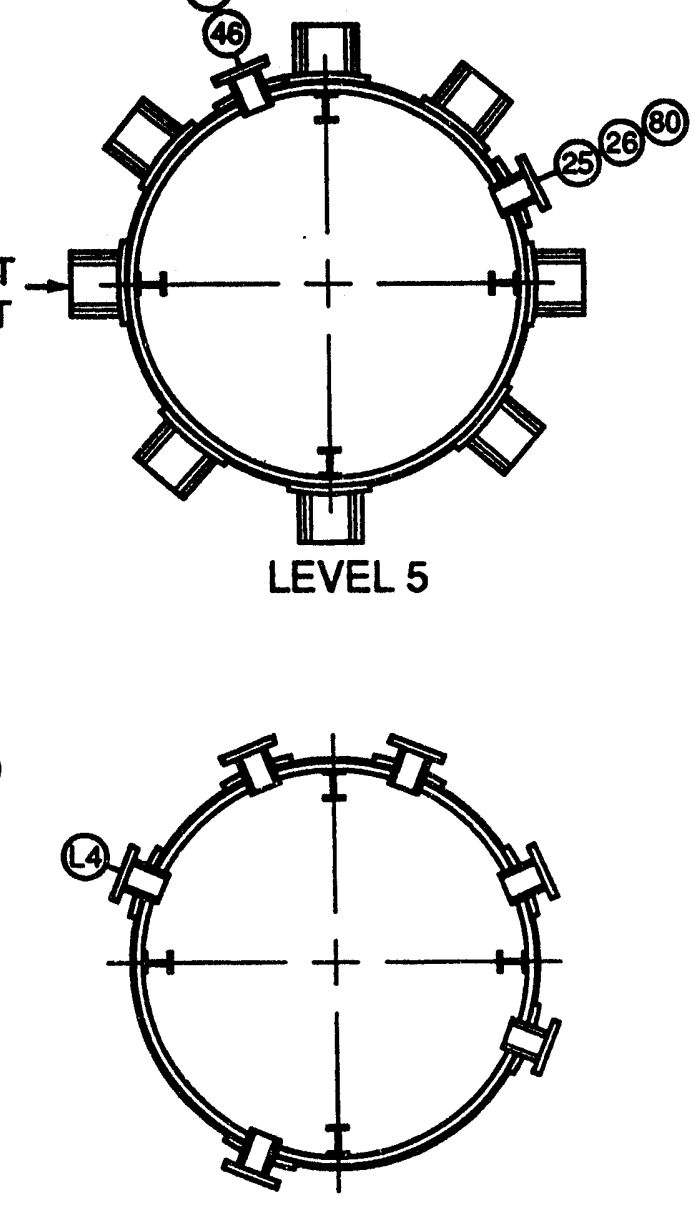

LEVEL 4

Figure 2.8 Top view of the Surtsey vessel showing instrumentation ports 

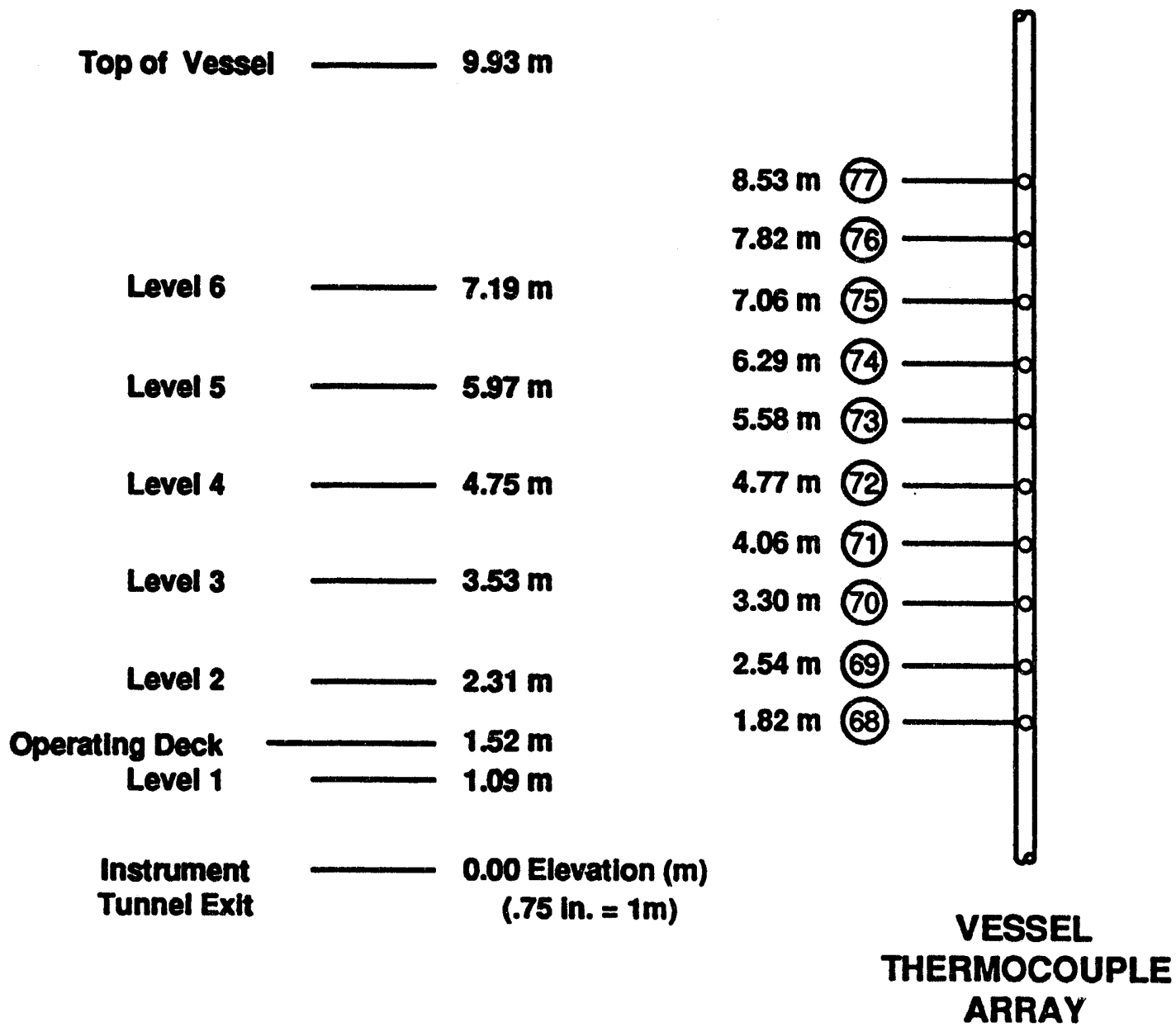

Figure 2.9 Location of Surtsey vessel bulk gas temperature thermocouple arrays 
Experiment Description

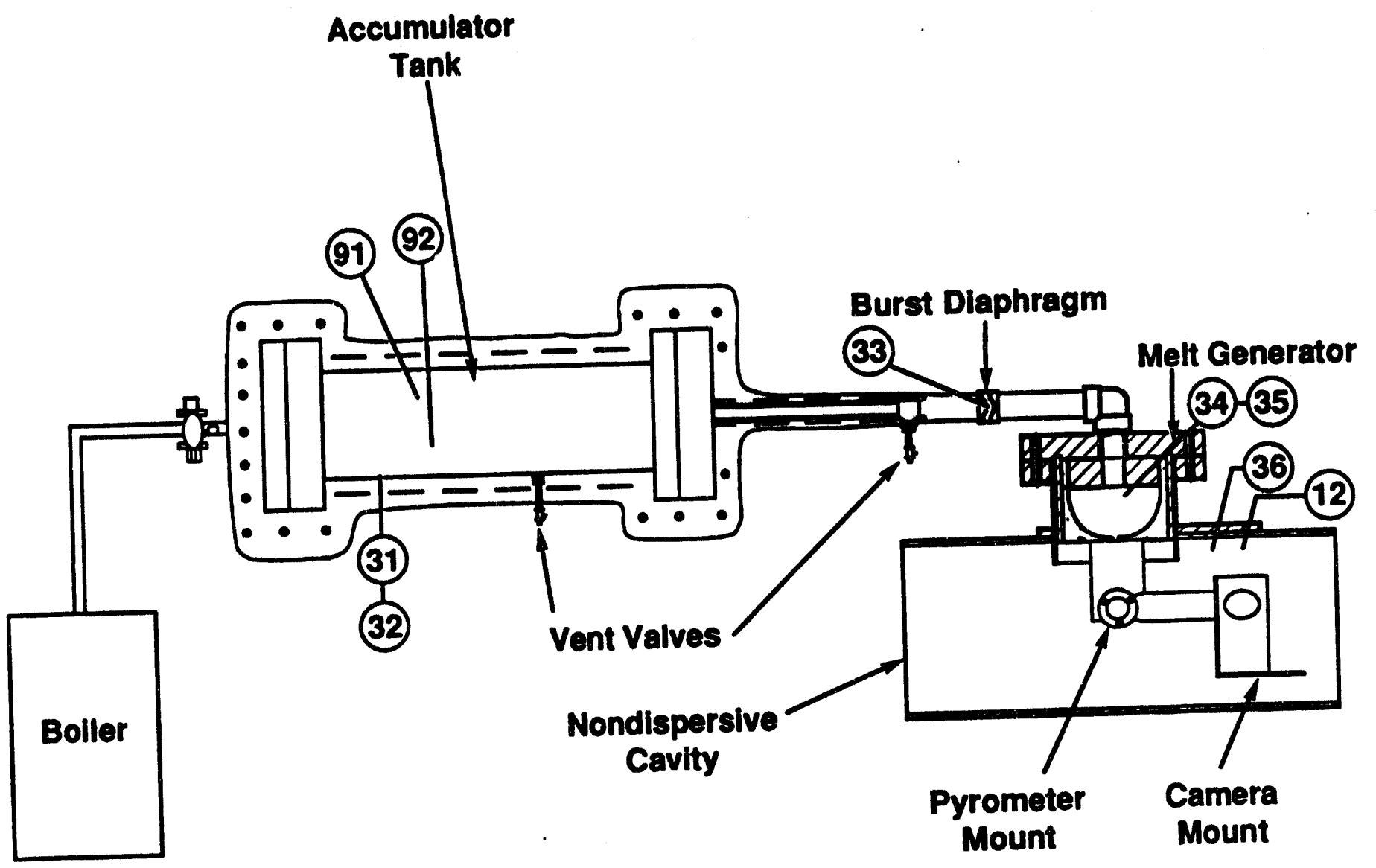

Figure 2.10 Composite view of the high-pressure steam boiler, steam accumulator, and burst diaphragm used in the IET-2 experiment 


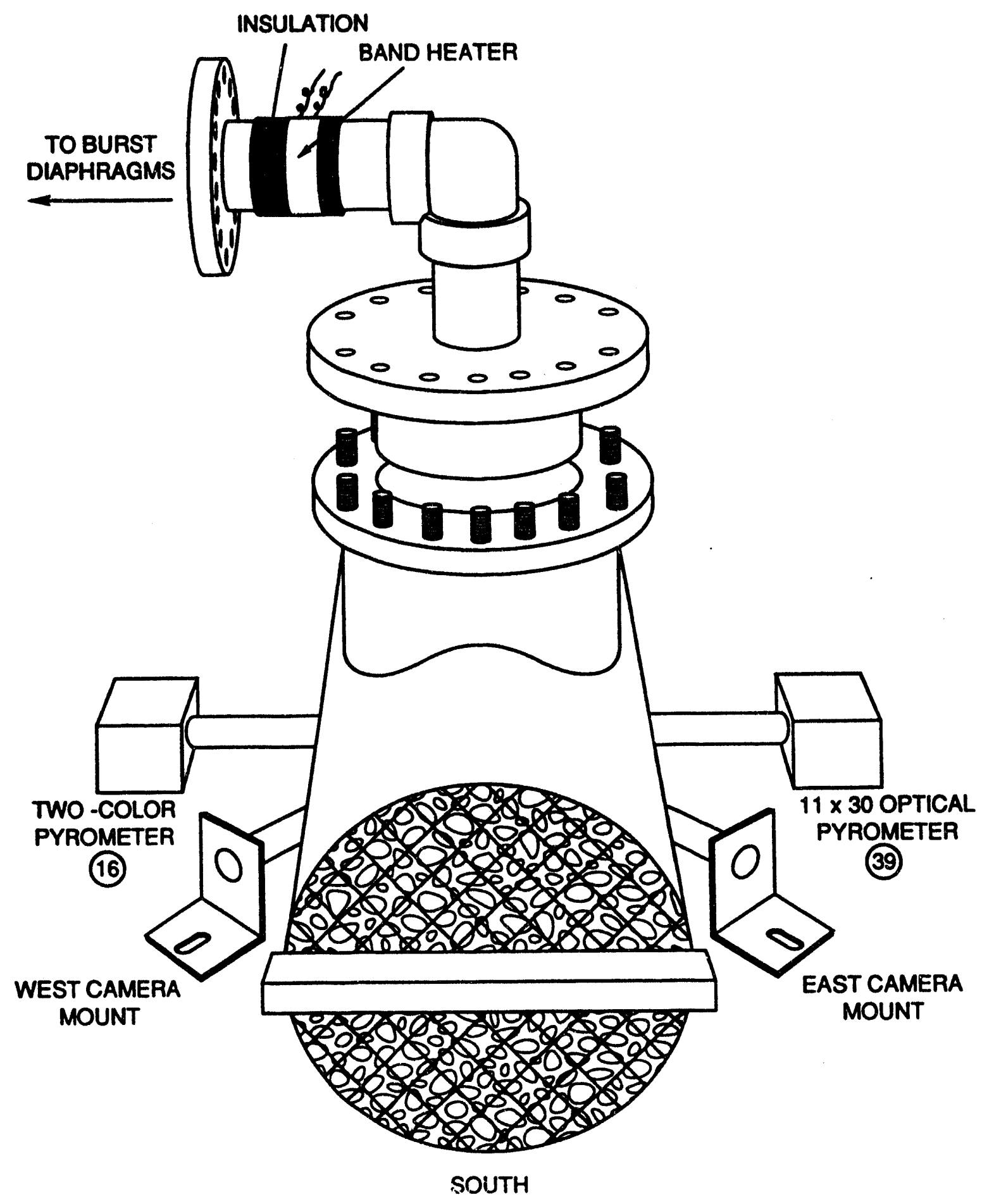

Figure 2.11 Isometric view of the nondispersive cavity used in the IET-2 experiments 
Experiment Description

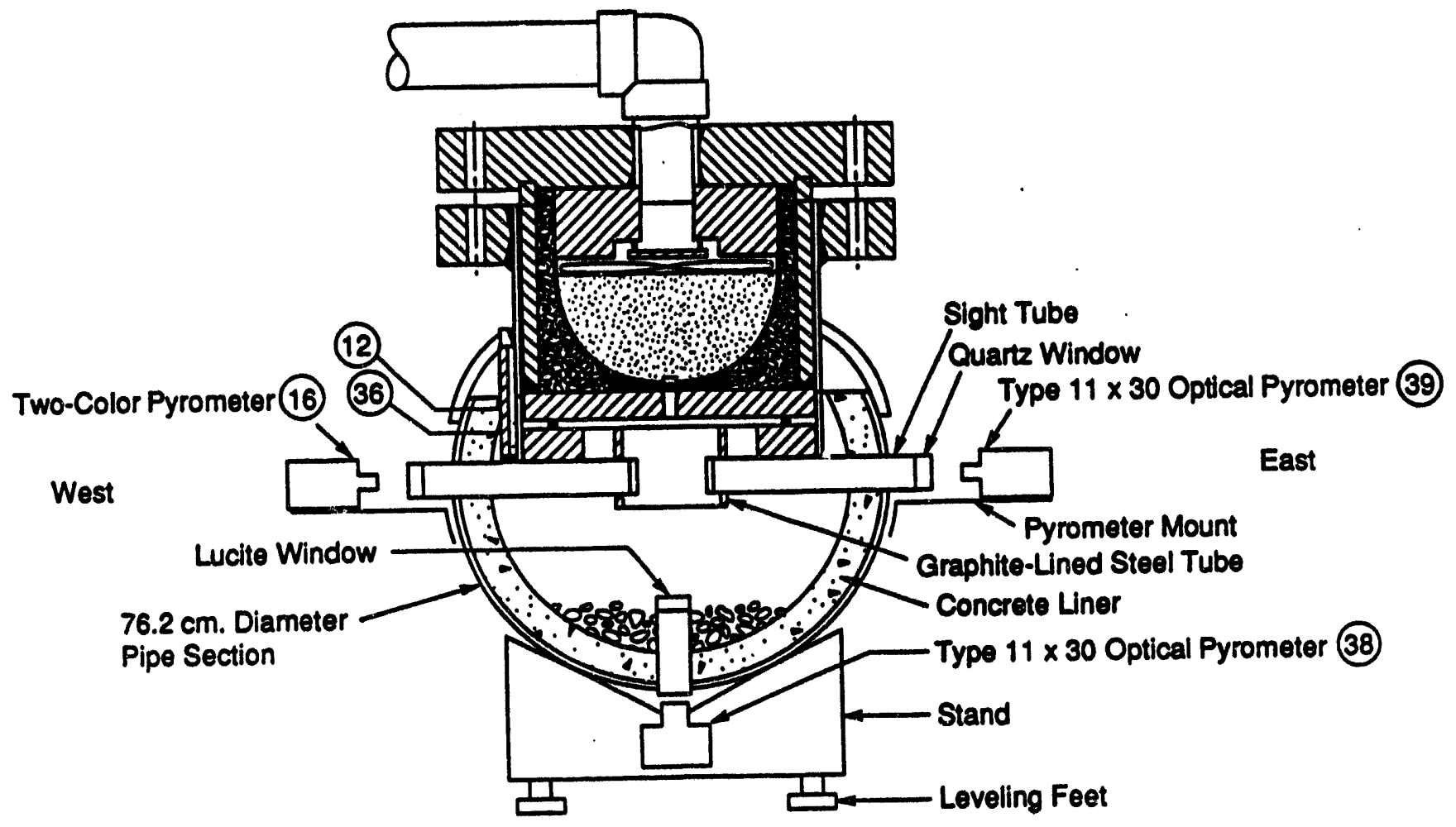

Figure 2.12 End view of the melt generator and the nondispersive cavity used in the IET-2 experiments 


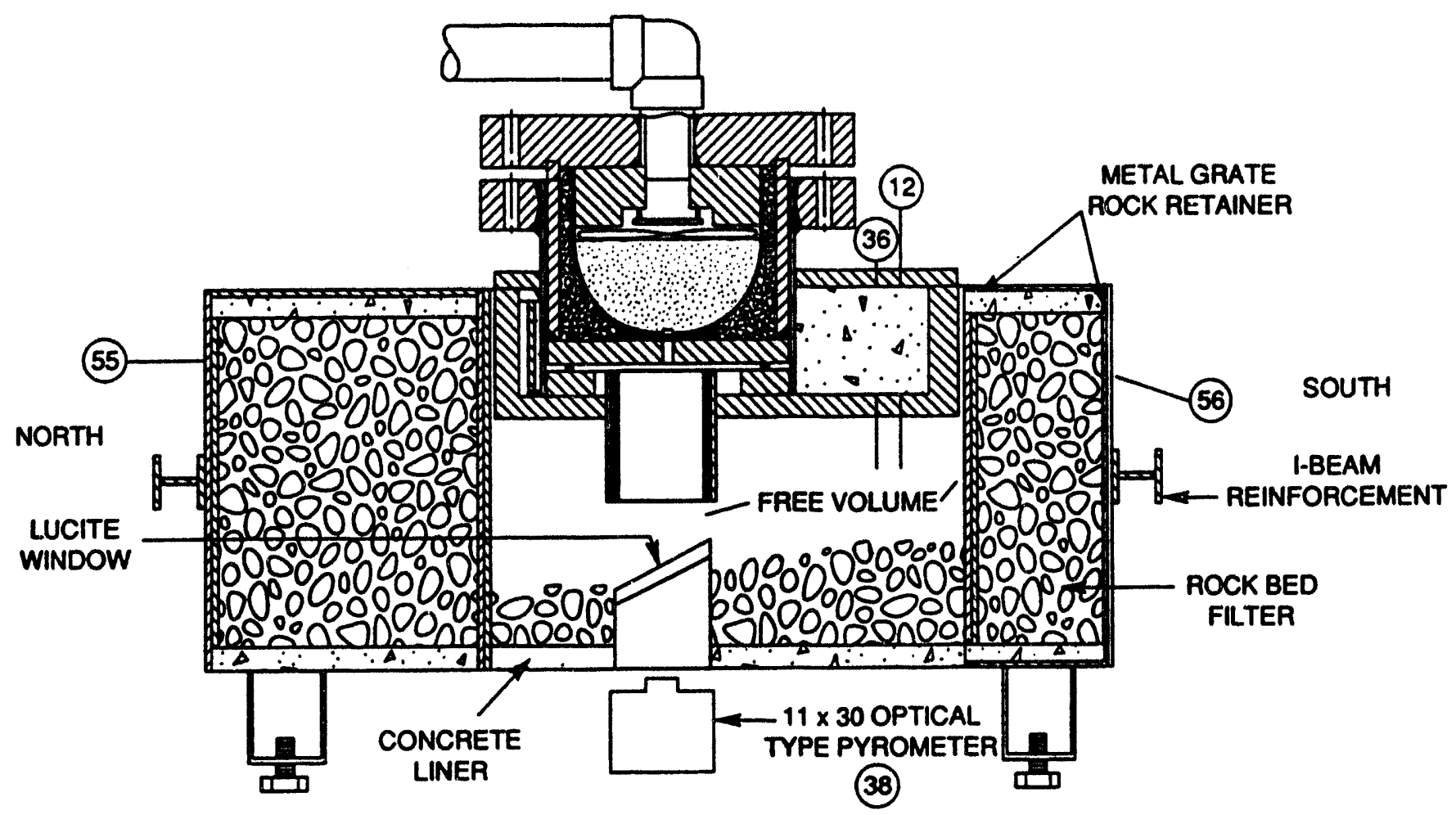

Figure 2.13 Side view of the melt generator and the nondispersive cavity used in the IET-2 experiments 


\subsection{Experimental Results}

\subsection{Blowdown History}

Figures 3.1 through 3.9 are the blowyiown histories for the IET-1, IET-1R, IET-3, IET-4, IET-5, IET-6, IET-7, IET-8A, and IET-8B tests, respectively. The blowdown histories are essentially the signature curves for the experiments and indicate whether the tests went as planned. In the IET experiments, the free volume in the crucible and in the $10-\mathrm{cm}$-diameter pipe above the crucible (volume $=0.018 \mathrm{~m}^{3}$ ) was purged with nitrogen. The accumulator tank (volume $=0.29 \mathrm{~m}^{3}$ ) was pressurized with superheated steam to $=6.3 \mathrm{MPa}$, and the burst diaphragm was concurrently pressurized to about 3.1 MPa. The crucible pressure started at about $0.1 \mathrm{MPa}$. The thermite was ignited at about $\mathrm{t}=$ $-10 \mathrm{~s}$. Crucible pressure started to rise, and at a pressure of $\approx 0.4 \mathrm{MPa}$, the burst diaphragm separating the steam accumulator tank and the molten thermite was failed remotely by the operator. This equilibrated the accumulator, burst diaphragm, and crucible pressures and brought steam into contact with the molten thermite a few seconds before the HPME. The blowdown curves give the steam driving pressure at $\mathrm{t}=0 \mathrm{~s}$, the steam blowdown time, and the time that steam was in contact with the molten thermite.

The burst diaphragms did not fail when they were supposed to in the IET-8A experiment. Thus, there was no high-pressure steam driving the thermite melt simulant. The cover gas above the thermite in the melt generator was nitrogen ( $4 \mathrm{~g} \cdot$ moles at ambient pressure). The pressure of the nitrogen cover gas increased when the thermite was ignited. When the melt plug failed, the molten thermite flowed under gravity through the hole in the melt generator into the reactor cavity model, which was half filled with water.

Figures 3.10 through 3.17 show the steam blowdown pressures for all of the IET tests, except IET-8A, measured with a pressure transducer located in the steam accumulator tank. In the IET experiments, the steam blowdown was complete at about $t=4 \mathrm{~s}$. These curves, along with the cavity pressure curves presented in Section 3.2.2, were used to determine the coherence ratio that is used in the two-cell equilibrium model to calculate the containment load.

The number of $\mathrm{g} \cdot$ moles of steam driving gas was calculated at HPME initiation $(t=0$ s) using accumulator steam pressure, temperature, and volume. At $t=0 \mathrm{~s}$, the steam pressure was normally about $6.3 \mathrm{MPa}$, the steam temperature was about $580 \mathrm{~K}$, and the volume of the accumulator tank plus the piping and void in the crucible was $0.308 \mathrm{~m}^{3}$. Therefore, the amount of steam driving gas for each of the IET experiments was usually about $500 \mathrm{~g} \cdot$ moles. The pressure, temperature, and number of moles of steam driving gas for each experiment are listed in Table 2.2.

\subsection{Pressure Measurements}

Pressure transducers were used to measure the pressure increase in the Surtsey vessel, in the cavity, in the seal table room, and in the subcompartment structures. The following sections describe the results of the pressure measurements.

\subsubsection{Surtsey Vessel Pressure}

Figures 3.18 through 3.26 show the Surtsey vessel pressures after the HPMEs plotted as a function of time for the IET experiments. The initial absolute pressure was $\approx 0.20 \mathrm{MPa}$, as listed in the table of initial conditions (Table 2.2). The pressures measured at levels 1 , 3 , and 5 in the Surtsey vessel with six different pressure transducers were virtually identical. These figures list the peak pressure increase for each of the IET experiments. The peak pressures were reached at $\approx 3 \mathrm{~s}$ after the beginning of the HPME transient. 
In IET-1 and IET-1R, the Surtsey atmosphere was purged with nitrogen so that the oxygen concentration was $<0.2 \mathrm{~mol}$. \% and hydrogen could not bum and contribute to vessel pressurization. Figures 3.18 and 3.19 show that the measured peak pressure increase in IET-1 was $98 \mathrm{kPa}$ and in IET-1R was $110 \mathrm{kPa}$. In IET-5, the vessel was "classically inerted" with carbon dioxide, which was used as a surrogate for steam, and preexisting hydrogen was present. Figure 3.22 shows that the peak pressure increase measured in IET-5 was $103 \mathrm{kPa}$, which is similar to the fully inerted cases, IET-1 and IET-1R.

There are two sources of potentially combustible hydrogen in a DCH event: (1) hydrogen produced during the HPME event by steam or water reactions with metallic debris, and (2) preexisting hydrogen released from the reactor coolant system prior to vessel failure. The enhanced loads due to hydrogen combustion are readily seen in Figures 3.20, 3.21, 3.23, and 3.24. When the Surtsey vessel atmosphere was reactive and the hydrogen was allowed to burn (IET-3, IET-4, IET-6, and IET-7), pressure increases of $246-279 \mathrm{kPa}$ were measured, indicating that hydrogen combustion made a significant contribution to containment pressurization. Comparison of experiments with and without preexisting hydrogen, but with otherwise similar initial conditions, e.g. IET-3 compared to IET-6 and IET-4 compared to IET-7, indicates that the preexisting hydrogen did not burn on the same time scale as the HPME. Thus, preexisting hydrogen in the vessel did not appear to contribute significantly to the peak pressure increase.

\subsubsection{Cavity Pressure}

The timing of debris ejection from the cavity into the subcompartment structures is important when analyzing a HPME/DCH event and is best understood by comparing the cavity pressure with the Surtsey vessel pressure. Figures 3.27 through 3.35 give the cavity pressures measured in the IET experiments plotted against time, where $t=0$ is the beginning of the HPME. These cavity pressure curves, along with the steam blowdown curves (Figures 3.10 through 3.17), are used to estimate the coherence ratio used in the two-cell equilibrium model to calculate the containment load.

In all of the IET experiments, a small initial pressure spike was observed, which was caused by efficient gas heating as molten brass, steel, and thermite entered the cavity. The second peak was apparently due to thermite/water interactions. The third broad peak in all the tests was the result of debris entrainment from the cavity by the steam blowdown. The debris entrainment occurred between $\approx 0.4 \mathrm{~s}$ and $\approx 0.8 \mathrm{~s}$ for all of the IET tests.

In the cavity pressure curves, the second set of peaks were due to thermite/water interactions. There were two distinctly different types of interactions observed: energetic thermite/water interactions, which are often referred to as steam explosions, and rapid vaporization of cavity water. The peaks in some of the IET tests, specifically IET-1, IET-6, IET-8A, and IET-8B, appeared to be the result of a steam explosion. These peaks had a short duration and a large magnitude compared to those which resulted from simple vaporization of cavity water, e.g. IET-1R and IET-3.

A series of steam explosions was seen in IET-8B (Figure 3.35). The explosions began immediately after the HPME initiation and continued throughout the blowdown of melt from the crucible, yielding the highest integrated pressure recorded in the test series. The first peak at $t \approx 0.04 \mathrm{~s}$ in the IET-8B curve was apparently due to a steam explosion. The second series of peaks from $\approx 0.08$ to $\approx 0.3 \mathrm{~s}$ was caused by a sustained series of energetic interactions between high-temperature thermite and cavity water. Debris entrainment by the steam blowdown occurred between $t \approx 0.4 \mathrm{~s}$ and $\approx 0.8 \mathrm{~s}$ in the earlier IET experiments [Allen et al. 1992c,d,e,f,g,h], and thus, it was assumed 
that the multiple peiks between $t=0.4 \mathrm{~s}$ and $\approx 0.8 \mathrm{~s}$ in IET-8B were the result of debris entrainment from the cavity. The gas-phase pressure transducer showed a peak pressure of $2.71 \mathrm{MPa}$, while the water-phase transducer showed smaller peaks; the largest water-phase peak pressure was $2.1 \mathrm{MPa}$.

\subsubsection{Preaure Measured Inside the Seal Table Room}

Figure 3.36 shows the absolute pressure measured inside the seal table room and the pressure measured in Surtsey plotted against time for the IET- 6 experiment. Pressure results in the other IET tests were similar. The seal table room pressure was positive with respect to the Surtsey vessel pressure between $=0.03$ to $0.04 \mathrm{~s}$, from $\approx 0.06$ to $0.2 \mathrm{~s}$, and from $\approx 0.55 \mathrm{~s}$ to $1.0 \mathrm{~s}$. This was confirmed by a positive seal table room differential pressure, shown in Figure 3.37, which was measured with a differential pressure transducer. These peaks were similar to the cavity pressure traces, but lagged in time and had smaller magnitudes. The first peak in the seal table room pressure was caused by molten material entering the cavity. The second larger pressure peak was probably caused by a thermitel water interaction in the cavity. The sensitivity of the seal table room pressure transducer was increased by a factor of two, thus effectively reducing its range from $0.69 \mathrm{MPa}$ to $0.345 \mathrm{MPa}$. Figure 3.36 shows that the transducer was overranged at $0.07 \mathrm{~s}$ and at $0.66 \mathrm{~s}$.

A breakwire was placed across the opening in the seal table room floor to measure the timing of debris ejection into the seal table room. Another breakwire was placed across the operating deck at the opening in the seal table room ceiling. Figure 3.37 shows the breakwire signals plotted on the same curve with the seal table room differential pressure for the IET- 6 experiment. The breakwire across the seal table room floor failed at $0.183 \mathrm{~s}$, possibly due to debris being ejected by the steam explosion in the cavity or due to debris driven from the cavity by its own momentum. The breakwire at the seal table room ceiling failed at $0.383 \mathrm{~s}$, near the start of the debris entrainment interval. The distance between breakwires is $0.848 \mathrm{~m}$; thus the debris velocity through the seal table room was $4.2 \mathrm{~m} / \mathrm{s}$. This was a typical measured velocity through the seal table room for many of the IET experiments, but appears to be unrealistically low when compared to dsbris velocities measured in the upper dome in these tests, i.e., $\approx 14 \mathrm{~m} / \mathrm{s}$. Debris velocities measured in the seal table room may have been unrealistically low because the floor breakwire was failed early by debris ejection from the cavity due to thermite/water interactions or to its own momentum, and the ceiling breakwire was failed by debris entrainment in the steam blowdown. The breakwires did not fail in the IET-8A experiment; without the steam driving force, virtually no debris was entrained from the cavity.

\subsubsection{Pressure Measured Inside the Subcompartment Structures}

Figure 3.38 shows the absolute pressure in the IET-6 experiment measured in the subcompartment structures and in the Surtsey vessel plotted for an experiment time of 0 to $1 \mathrm{~s}$. Figure 3.39 shows the differential pressure in the IET-6 experiment between the subcompartment structures and the Surtsey vessel upper dome. A peak differential pressure of $0.119 \mathrm{MPa}$ in the subcompartment structures occurred at $0.068 \mathrm{~s}$. IET-6 had the largest steam explosion of any of the tests with condensate levels of water in the cavity.

In all of the IET experiments, the absolute pressure measurements in the subcompartment structures and the differential pressure measurements between the subcompartment structures and the Surtsey vessel upper dome revealed that there was little or no differential pressure between the vessel and subcompartments except during steam explosions. This result was expected because of the large openings in the operating deck above the RCPs. 


\subsection{Video Results and Interpretation}

The high-speed video cameras viewed the HPME through Plexiglas ports installed in the top head of the vessel and at level 3 (Figure 2.1). A bright orange plume was seen in the upper dome of the Surtsey vessel in all the tests that had a reactive atmosphere ( 9 to 10 mole $\left.\% O_{2}\right)$, indicating that a hydrogen bum did occur. Individual luminous molten debris particles were ejected from the subcompartment structures and were observed moving toward the upper dome of the Surtsey vessel. Hydrogen formed by steam/ metal reactions in the HPME that is ejected into the upper dome is intimately mixed with molten particles, which act as ignition sources for hydrogen combustion. Hydrogen entrained in the debris plume apparently burns fairly efficiently in the upper dome of the vessel.

The following is a synopsis of typical observations made from the videos recorded by the highspeed cameras. The high-speed camera inside the vessel viewing the chute exit showed that the subcompartment structures began filling with aerosols at $t=0.048 \mathrm{~s}$. Apparently, the optical pyrometers did not accurately measure debris temperatures in the Zion scaled models because aerosols in the containment basement obscured the optical path. The side camera at level 3 showed a faint orange gas jet at $t=0.2 \mathrm{~s}$, which was probably a hydrogen burn from the seal table room plug opening or the RCP 1C vent. At about $\mathrm{t}=0.4 \mathrm{~s}$, a broader and brighter orange gas jet appeared. This time corresponds to the beginning of the debris entrainment by the steam blowdown, which was determined from the cavity pressure curves. Molten particles could be seen rising in the gas jet at a velocity of $\approx 14 \mathrm{~m} / \mathrm{s}$, which is similar to the $16 \mathrm{~m} / \mathrm{s}$ calculated from the breakwire array data obtained in the LFP-8A experiment [Allen et al. 1991b], although the agreement may be somewhat fortuitous since the tests used different geometries and driving pressures. At about $\mathrm{t}=1 \mathrm{~s}$, molten particles began to fall. The gas burn started to dissipate at about $t=1.5 \mathrm{~s}$, and by $t=2.5 \mathrm{~s}$ the view was obscured by high aerosol concentrations.

The top port camcorder showed aerosols exiting the opening in the seal table room ceiling and the seal table room doorway in the crane wall at $t=0.03 \mathrm{~s}$. The second frame showed that the RCP vents in the operating dock floor were filled with aerosols. The third frame showed that the vessel was filled with aerosols to a level slightly above the steam generators at $\mathrm{t}=0.10 \mathrm{~s}$. Bright, white plumes were seen at the plug opening, RCP 1A and $1 \mathrm{C}$ vents, and at the crane wall doorway at $t=0.16 \mathrm{~s}$. At $t=0.3 \mathrm{~s}$, bright orange flames and luminous debris particles were ejected from the subcompartments and later filled the vessel.

The flow area through the vent grating above the four RCPs is $0.6 \mathrm{~m}^{2}$; this area does not take into account the area blocked by the metal grating. The flow area through the annulus around the four steam generators through the operating deck is $0.03 \mathrm{~m}^{2}$. The flow area through the seal table room ceiling opening is $0.003 \mathrm{~m}^{2}$. There are three doors through the crane wall: an upper and a lower door on the north side, and a door on the east face. Their flow area is $0.08 \mathrm{~m}^{2}$. Therefore, the total possible flow area for hydrogen venting and burning out of the subcompartment structures to the vessel dome is $0.71 \mathrm{~m}^{2}$. In films where the vessel was not inerted, orange flames were observed at all vent openings, including the doorways. This indicates that hydrogen was venting and burning at all openings.

The camcorder video results from the IET-8B experiment are described here. The first frame of the top port camcorder, at the beginning of HPME, showed light and dark gray clouds exiting the seal table room plug opening and the crane wall doorway at $t=0.03 \mathrm{~s}$. This cloud was probably a mixture of aerosol, steam, and water droplets. A loud shotgun type sound was heard in the vessel. The second frame showed 
that the RCP vents in the operating deck floor were filled with acrosols at $t=0.06 s$. The third frame showed that the vessel was filled with aerosols to a level slightly above the steam generators at $t=0.10 \mathrm{~s}$. These plumes of aerosols had reached mid-vessel by the $9^{\text {t }}$ frame at $\mathrm{t}=0.3 \mathrm{~s}$. Bright, white plumes of flames were seen at the plug opening, RCP 1A and 1C vents, and at the crane wall doorway in the $10^{\circ}$ frame. From $t=0.33 \mathrm{~s}$ to $1.0 \mathrm{~s}$, orange flames and debris were seen rising in the vessel. Molten debris and water drops impacted on the top viewing port at $1.0 \mathrm{~s}$; clicking and tapping noises were heard. From $t=1.0 \mathrm{~s}$ to about $2.7 \mathrm{~s}$, the debris fell downward, until the view was obscured by dense concentrations of aerosols.

The high-speed video cameras viewed the HPME through Plexiglas ports installed in the top head of the vessel and at level 3 in IET-8B (Figure 2.1). A bright orange plume was seen in the upper dome of the Surtsey vessel, indicating that a hydrogen bum did occur. Individual luminous molten debris particles were ejected from the subcompartment structures and were observed moving toward the upper dome of the Surtsey vessel. The following is a synopsis of observations from the high-speed cameras in IET-8B.

The side view camera at the level 3 port recorded 1059 frames per second.

Time (s) Comments

$0.000 \quad$ At time $t=0 \mathrm{~s}$, the view was black.

0.602 An orange plume of light appeared, indicating the beginning of a hydrogen burn.

0.630 A jet of molten particles moved upward in the center of burning gas.
Trme (8) Comments

$\mathbf{0 . 7 7 2}$ The first jet of molten debris stopped.

0.893 Another less vigorous debris jet moved upward, slightly to the right of the first jet.

1.001 Molten debris ejection stopped.

1.132 The view was entirely black. No falling particles were visible.

The camera at the top port recorded 1012 frames per second.

Time (s) Comments

$0.000 \quad$ At time $t=0 \mathrm{~s}$, the operating deck and refueling canal could be seen.

0.604 A faint orange glow appeared from either the seal table room or the RCP 1 A vent opening.

0.634 Molten particles rose through the burning gas.

0.659 A piece of concrete struck the top port.

1.232 Glowing molten particles struck the top port.

1.401 The molten debris appeared to be suspended in space, and then fell.

2.440 The view faded to black.

\subsection{Debris Temperature Measurements}

Two pyrometers were used in the IET-2A experiment to measure the temperature of the molten thermite as it exited the melt generator. 
A two-color pyrometer was located on the west side, and a type 11x30 optical pyrometer was positioned on the east side of the nondispersive cavity. In the IET-2B and IET-2C tests, another type $11 \times 30$ optical pyrometer was placed under the cavity and was focused upward at the exit hole in the bottom of the melt generator.

Figures 3.40, 3.41, and 3.42 show the results of the two-color pyrometer for the IET-2A, IET-2B, and IET-2C tests, respectively. The peak melt temperatures were $\approx 2300 \mathrm{~K}, \approx 2550 \mathrm{~K}$ and $\approx 2450 \mathrm{~K}$, respectively. Figures $3.43,3.44$, and 3.45 show the temperature measurements for the $11 \times 30$ optical pyrometer mounted on the east side for the IET-2A, IET-2B, and IET-2C tests, respectively. The peak debris temperatures measured by the $11 \times 30$ pyrometer were between 2000 and $2100 \mathrm{~K}$ for the three tests, which were considerably lower than the temperatures measured with the two-color pyrometer. The two-color pyrometer is apparently less sensitive to the condensed-phase aerosols at the outer edges of the debris jet than the $11 \times 30$ optical pyrometer. Figures 3.46 and 3.47 show the temperature measurements from the $11 \times 30$ optical pyrometer located below the cavity in the IET-2B and IET-2C tests. Figure 3.46 shows a peak debris temperature of $\approx 2525 \mathrm{~K}$ occurring at $\approx 0.1 \mathrm{~s}$ in IET-2B, and Figure 3.47 shows a peak temperature of $\approx 2550 \mathrm{~K}$ occurring at $\approx 0.5 \mathrm{~s}$ in IET-2C.

Table 3.1 summarizes the comparative results of the IET-2A, IET-2B, and IET-2C experiments. Based on the temperature measurements from the three IET-2 experiments, the peak temperature of the molten thermite exiting from the melt generator was $\approx 2550 \mathrm{~K}$. Steam in contact with the melt appeared to have no effect on thermite temperature. The optical pyrometer orientation with respect to the direction of the melt ejection did have a noticeable effect on the temperature measurement: the pyrometer viewing the debris jet from below the cavity measured temperatures $\approx 500 \mathrm{~K}$ greater than the pyrometer viewing the debris jet from the side, indicating that the outside surface temperature of the debris jet may be approximately $500 \mathrm{~K}$ lower than the core temperature. It was difficult to avoid aerosol effects in side measurements, even with the viewing tubes used; however, the two-color pyrometer appeared to be less sensitive to these effects than the optical pyrometers.

It should be noted that the temperatures measured in the IET-2 tests were above the peak temperatures of $2300 \mathrm{~K}$ determined in the LFP and WC tests [Allen et al. 1991b; Allen et al. 1992a,b]. The temperatures measured in these experiments were outside surface temperatures of debris exiting the cavity. It is suspected that the lower temperatures determined by the optical pyrometers in the IET-1, IET-1R, [Allen et al. 1992e], IET-3 [Allen et al. 1992c], and IET-4 [Allen et al. 1992d] experiments may be caused by aerosols in the subcompartment structures that partially obscured the optical path between the sensing head and the focal point of the pyrometer.

\subsection{Gas Temperature Measurements}

Figure 3.48 shows the measured temperatures in the triangular vent spaces above the 1A RCP plotted against time for the IET tests. The peak temperature in the $1 \mathrm{~A}$ vent space normally reached about $1000 \mathrm{~K}$ regardless of hydrogen combustion. In IET-1, the thermocouple was bent away from the vent opening by the steam explosion and thus the reading was low. Posttest inspection of the thermocouple in IET-3 indicated that debris had interacted with it, and thus, the measured temperature was higher than those in the other tests. The gas temperatures in the vent spaces for the other IET tests are well below combustion temperatures, indicating the gas jet was burning above the vent opening. Large amounts of water in the cavity in IET-8A and IET-8B limited the gas temperature in the vent space to near the saturation values.

The gas temperatures were measured at the side wall of the Surtsey vessel at levels 1,3 , and 5 
using aspirated thermocouples. The results for IET-1, IET-1R, IET-3, IET-4, IET-5, IET-6, IET-7, and IET-8B are shown in Figures 3.49 through 3.56. The aspirated thermocouple valves failed to open in IET-1R and, therefore, the results of IET-1R should not be considered. The tests with inert atmospheres showed level 3 temperatures of $\approx 630 \mathrm{~K}$ for IET-1 and $\approx 560 \mathrm{~K}$ for IET-5. The tests with reactive atmospheres (IET-3, IET-4, IET-6, and IET-7) showed level 3 temperatures between 1040 and $1100 \mathrm{~K}$. Thus, tests with reactive atmospheres had much higher gas temperatures in the upper dome than tests with inert atmospheres. However, the tests with preexisting hydrogen did not have higher gas temperatures than those without preexisting hydrogen. This is evidence that preexisting hydrogen did not react on a time scale that could contribute to the peak containment loac

In the IET-4, IET-5, IET-6, IET-7, IET-8A, and IET-8B experiments, thermocouple arrays were added to the upper dome of the Surtsey vessel to measure the bulk average gas temperatures. Average gas temperatures from the vessel dome thermocouple arrays are shown in Figure 3.57. These thermocouples measured temperatures from the operating deck to above level 6 . The lower thermocouples measured higher temperatures than the higher thermocouples, indicating temperature stratification with higher temperatures lower in the vessel. The peak gas temperatures were about $600-700 \mathrm{~K}$ for the tests that had reactive atmospheres and a small amount of water in the cavity (IET- 4, IET-6, and IET-7); however, these temperature are well below the autoignition temperature of the mixture ( $\approx 850 \mathrm{~K}$ ). In IET-5, the Surtsey vessel atmosphere was classically inerted with $\mathrm{CO}_{2}$ and the average gas temperature in the vessel was less than $400 \mathrm{~K}$, which indicates that the hydrogen formed in the HPME did not burn efficiently as it entered the upper dome. Large amounts of cavity water in the IET-8A and IET-8B tests apparently quenched the debris and thus reduced the vessel bulk gas temperature to $400-460 \mathrm{~K}$.
Figures $3.58,3.59$, and 3.60 show the relative magnitude of the pressure increase compared to the relative magnitude of the bulk gas temperature increase for the experiments with reactive atmospheres, i.e., IET-4, IET-6, and IET-7, respectively. The relative magnitude of the pressure increase compares fairly closely with the increase in the relative magnitude of the average gas temperature, which indicates that not much of the pressure was the result of blowdown steam or water vaporized from the cavity or basement floors.

The upward gas velocities were calculated from the temperatures measured by the dome thermocouple array shown in Figure 2.9. The gas temperatures measured in IET-7 are plotted in Figure 3.61. The upward gas velocity between $1.8 \mathrm{~m}$ (channel 68) and $7.1 \mathrm{~m}$ (channel 75) $v / a s \approx 5 \mathrm{~m} / \mathrm{s}$. Results from videos showed that the debris particles were moving at a velocity of 14 to $17 \mathrm{~m} / \mathrm{s}$. Apparently, the debris particles at level 3 were transported by momentum rather than by drag. At $t=1.6 \mathrm{~s}$, the gas seemed to lose the push from the steam blowdown, and moved upward at a much slower velocity, i.e., $\approx 1 \mathrm{~m} / \mathrm{s}$.

At long times after the HPME (i.e., $t=29 \mathrm{~s}$ in Figure 3.62), the gas temperature in the vessel was clearly stratified. The temperature measured by the top thermocouple in the array (channel \#77) was about $70 \mathrm{~K}$ hotter than the temperature measured by the lowest thermocouple in the array (channel \#68). The stratification was very stable at long times.

The peak gas temperatures in the dome of the Surtsey vessel were measured by thermocouples $\# 72$ through \#75. These thermocouples were located at elevations between 4.77 and 7.06 meters, which is in the upper middle part of Surtsey (Figure 2.9). The measured peak gas temperatures were $830 \mathrm{~K}$ (Figure 3.63) and were coincident with the peak pressures, which occurred at $t \simeq 2.8 \mathrm{~s}$. The peak gas 
Experimental Results

temperatures above $7.8 \mathrm{~m}$ (channels \#76 and \#77) never exceeded $640 \mathrm{~K}$.

Figures 3.64 and 3.65 show the relative magnitude of the pressure increase compared to the bulk gas temperature increase for the experiments with the cavity half filled with water, i.e., IET-8A and IET-8B, respectively. In both tests, the relative magnitude of the vessel average gas temperature was significantly lower than the relative magnitude of the vessel pressure. This means that the additional vessel pressure was due to vaporization of cavity water. However, the peak pressure increase in IET-8B (0.244 MPa) was not much different from those measured in experiments with similar initial conditions, e.g. IET-3 (0.246 MPa), IET-4 (0.262 MPa), IET-6 $(0.279 \mathrm{MPa})$, and IET-7 (0.271 MPa). For experiments with significant levels of cavity water, the water apparently has competing effects: the molten debris vaporizes water and thus adds moles of steam to the vessel, but at the same time, the cavity water quenches the debris and thus reduces vessel pressurization due to direct debris-to-gas heat transfer.

Figure 3.65 shows that the amount of pressurization in IET-8B cannot be attributed to heating of the atmosphere alone; consequently, some significant amount of the pressurization must be coming from additional moles of steam. The additional gas moles can be estimated from the ideal gas law

$$
\begin{aligned}
\Delta N & =\left[\frac{P_{f}}{T_{f}}-\frac{P^{\circ}}{T^{\circ}}\right] \frac{V}{R} \\
& =\left[\frac{0.447 \times 10^{6}}{462}-\frac{0.203 \times 10^{6}}{298}\right] \frac{89.9}{8,314} \\
& =3096 \mathrm{~g} \cdot \text { moles. }
\end{aligned}
$$

Of this $3096 \mathrm{~g} \cdot$ moles, $2551 \mathrm{~g} \cdot$ moles $(45.9 \mathrm{~kg})$ can be attributed to water vaporization, with the remaining $565 \mathrm{~g} \cdot$ moles coming from the accumulator blowdown. This $45.9 \mathrm{~kg}$ of vaporized water represents $74 \%$ of the water initially in the cavity. These results suggest that vaporization of cavity water might have been quite efficient.

The efficiency of melt/water interactions can be explored from an energy perspective. The melt injected into the cavity $(43 \mathrm{~kg} \times 0.94=40.4 \mathrm{~kg})$ contains $101 \mathrm{MJ}$ thermal energy and $25 \mathrm{MJ}$ of oxidation energy. As an upper bound, (assuming complete quenching to saturation) the thermal and chemical contributions could vaporize $2403 \mathrm{~g} \cdot$ moles and $613 \mathrm{~g} \cdot$ moles of water $(30 \mathrm{~K}$ subcooled), respectively. The chemical energy is dominated by $\mathrm{Cr}$ and $\mathrm{Al}$ oxidation, which is easily realized. Consequently, full credit for the oxidation energy is taken into account. To be consistent with the observed containment pressurization, $2551 \mathrm{~g} \cdot$ moles of water must have been vaporized by the melt, which has the potential for vaporizing $2403+$ $613=3016 \mathrm{~g} \cdot$ moles of water. Thus, $85 \%$ of the water that could have been vaporized appeared to have been vaporized in IET-8B. Apparently, quenching of the melt was quite efficient, and the small amount of atmosphere heating observed in the test was likely dominated by saturated steam entering the upper dome and by hydrogen combustion in the debris plume as it entered the upper dome.

The quantitative observations of IET-8B are in contrast to subjective observations from HIPS - 4W, 6W, 9W [Tarbell et al. 1991]. In these earlier tests, it was reported that a significant portion of the water was ejected as a slug that preceded debris dispersal. The conditions of IET-8B are not, however, fully consistent with the HIIPS tests. In particular, the HIPS tests employed an open geometry so that the water slug and debris jet were dispersed into an open atmosphere, which did not force intimate contact between water and molten debris. In IET-8B, the cavity water may have been partially ejected as a slug that impacted the subcompartment structures. Dispersed debris from the cavity may have mixed 
violently with water deflected by the subcompartment structures back into the path of the dispersed debris, causing efficient vaporization of cavity water in the subcompartments. In addition, the HIPS tests had twice the melt mass of IET-8B and two of the HIPS tests had fully water locked cavities.

\subsection{Gas Composition Measurements}

Normally, about sixteen gas grab samples were taken from the Surtsey vessel in the IET experiments. Background samples from Surtsey were taken just prior to ignition. The background gas concentrations are listed in Table 2.2. The amounts of hydrogen in $\mathrm{g} \cdot$ moles are listed in Table 3.2 for each IET test except the IET-2 series. The values given include the amount preexisting in the vessel, the amount produced by steam/metal reactions in the HPME, the amount burned, and the amount measured posttest. The amounts of hydrogen produced and burned listed in Table 3.2 were measured 30 minutes after the HPME when the vessel atmosphere was well mixed; however, the measured gas concentrations did not change much between 2 minutes and 30 minutes, indicating that the atmosphere was well mixed at 2 minutes after the HPME.

Gas bottle measurements give the amounts of hydrogen and oxygen in the Surtsey vessel pretest and at various times posttest. Calculations of the amounts of hydrogen burned were based on the assumption that all oxygen depletion was due to the stoichiometric reaction with hydrogen to form water. The amounts of hydrogen produced were calculated by subtracting the measured amount of pretest hydrogen from the measured amount of posttest hydrogen plus the amount of hydrogen burned, calculated from oxygen depletion measurements. For IET tests with reactive atmospheres (IET-3, IET-4, IET-6, IET-7, IET-8A, and IET-8B), the amounts of hydrogen produced and burned may be overpredicted by this method since oxygen can also be depleted by direct reactions with metallic debris. Comparisons of results from experiments with inert atmospheres and reactive atmospheres indicate that the amounts of hydrogen produced and burned given in this section for the experiments with reactive atmospheres could be overpredicted by 20 to $30 \%$.

Figure 3.66 shows oxygen concentration depletion measurements for the IET tests. Background sample measurements are shown for the majority of the tests, along with 2 and 30 minute results. There were no 2 minute samples in IET-1R and IET-3. The 2 minute samples shown for IET-1R and IET-3 are projected results based on comparable tests, i.e. IET- 1 and IET-4. In IET-8A, the 2 minute and 30 minute samples reported in Figure 3.66 were actually taken at 30 seconds and 900 minutes, respectively. In IET-8B, additional samples were taken at 15 s. As expected, oxygen levels remained constant in IET-1 and IET-1R. In IET-5, the $\mathrm{CO}_{2}$ inerted test, oxygen depletion was about 0.4 mole $\%$. In the gravity pour test (IET-8A), oxygen depletion was about 0.8 mole \%. Oxygen defietions of about 1.2-2.2 mole \% were measured between $t=0$ and $t=2$ minutes in the tests with reactive atmospheres.

Figure 3.67 shows the hydrogen measurement results. There was no preexisting hydrogen in IET-1, IET-1R, IET-3, and IET-4. Measurements from IET-1, IET-1R, and IET-5 show that the majority of the hydrogen (about 3-3.5 mole \%) was produced in the first few minutes, with an insignificant long-term buildup. In tests with a reactive atmosphere (IET-3 and IET-4), the hydrogen produced by the HPME burned and the final concentrations were less than 1 mole \%. Figure 3.67 indicates that in tests with reactive atmospheres and preexisting hydrogen (IET-6 and IET-7), more hydrogen was burned than was produced in the first two minutes, yielding final concentrations less than the initial background values. This means that all of the hydrogen produced by metal/steam interactions in the HPME burned and some of the preexisting hydrogen burned. IET-8B shows that driving 
melt into a cavity half filled with water can increase hydrogen levels very quickly. Gas measurements in the cavity for all IET tests indicate very high hydrogen levels (50-84 mole \% of the noncondensible gases) by $2 \mathrm{~s}$ into the HPME transient. This indicates that the entraining gas in the cavity was a mixture of steam and hydrogen, which is important because many analytical entrainment models require the composition of the entraining gas.

Figure 3.68 gives the $g \cdot$ moles of hydrogen burned in the IET tests. Little combustion was seen IET-1 and IET-1R. In IET-3, which was a baseline test with a reactive atmosphere and no basement water, about $190 \mathrm{~g} \cdot$ moles bumed. In IET-4, which was similar to IET-3 except that condensate levels of water were on the containment basement floor, slightly more hydrogen bumed ( $235 \mathrm{~g} \cdot$ moles). The largest amounts of hydrogen bumed (about $330 \mathrm{~g} \cdot$ moles) in the tests with preexisting hydrogen in a reactive atmosphere (IET-6 and IET-7). With $\mathrm{CO}_{2}$ as a surrogate for steam, only $50 \mathrm{~g} \cdot$ moles burned in IET-5, even though $202 \mathrm{~g} \cdot \mathrm{moles}$ preexisted and $319 \mathrm{~g} \cdot$ moles were produced in the HPME. In the tests that had the cavity half filled with water, there was less hydrogen combustion than in a comparable test with condensate levels of water in the cavity (i.e., IET-7). About 114 $\mathrm{g} \cdot$ moles of hydrogen combusted in the gravity pour test (IET-8A), and about twice that amount, $223 \mathrm{~g} \cdot$ moles, in IET-8B when the melt was driven at high pressure into the half-filled cavity.

Figure 3.69 compares the time rate of hydrogen production in the IET tests. Hydrogen production amounts are calculated by subtracting the pretest hydrogen amount from the sum of the posttest hydrogen amount and the amount of hydrogen burned, calculated from oxygen depletion measurements. About $230 \mathrm{~g} \cdot$ moles of hydrogen were produced in the high-pressure steam driven tests with no water on the basement floor (IET-1, IET-1R, and IET-3). About $290 \mathrm{~g} \cdot$ moles were produced in tests with condensate levels of water on the basement floor (IET-4, IET-5, and IET-7).
Even though IET- 6 had no water on the basement floor, about $300 \mathrm{~g} \cdot$ moles of hydrogen were produced. This may have been the result of a large steam explosion in the cavity at HPME initiation. About $100 \mathrm{~g} \cdot$ moles were produced in IET-8A, the gravity pour test. The 15 second samples taken during the IET-8B test indicate that hydrogen is produced and burned very quickly, as shown in Figures 3.68 and 3.69.

Figure 3.70 gives the net difference between hydrogen production and combustion in the IET experiments. In the majority of the tests, more hydrogen was produced than was burned, especially in the inerted tests, IET-1, IET-1R, and IET-5, as expected. In IET-6 and IET-7, more hydrogen burned than was produced. This indicates that 30 to $50 \mathrm{~g} \cdot$ moles of preexisting hydrogen must have burned. It also appears that in the test in which the cavity was half filled with water (IET-8B), water that was vaporized by the debris jet may have prevented preexisting hydrogen from burning.

\subsection{Debris Recovery Summary}

Concrete structures were damaged during some of the IET tests. The crane wall suffered significant damage during IET-4. An $\approx 40 \times 80$ $\mathrm{cm}$ hole was blown out of the crane wall near the top of the seal table room. The crane wall was also cracked near the walls of the seal table room about $30 \mathrm{~cm}$ from the top of the operating deck. It is believed that repeated, direct hits of molten debris may have dehydrated and weakened the concrete in this region.

The cavity floor suffered damage during the IET6 test. A hole in the concrete $\left(\approx 7080 \mathrm{~cm}^{3}\right)$ directly beneath the crucible melt plug was discovered. IET-6 had the largest steam explosion of any of the IET tests, and this may have caused the damage to the cavity floor. Additionally, the opening in the seal table room floor was enlarged by $\approx 1545 \mathrm{~cm}^{3}$. For the experiments that suffered damage to the concrete structures, the mass of debris recovered was 
corrected for concrete contaminants as described later in this section.

In the IET-8A and IET-8B tests, there was a lip surrounding the chute exit that prevented subcompartment water from draining down the chute prior to the HPME transient. The lip was blown away during both tests allowing water and condensed steam to drain into the cavity. Posttest examination in IET-8A revealed that the cavity was full of water. Apparently, water on the containment basement floor flowed into the cavity after the lip around the chute exit was destroyed in the experiment. IET-8A posttest examination also showed that the majority of the melt debris remained in the cavity, forming a crust approximately $6 \mathrm{~cm}$ thick. In IET-8B, posttest examination also revealed that the cavity was filled with water, but that very little debris remained in the cavity and chute. The subcompartment structures sustained significant damage during the IET-8 experiments. In both experiments the seal table room floor was destroyed; the concrete was completely removed and the exposed reinforcement bars were bent up and into the seal table room. The damage to the structures was probably caused by high pressures in the cavity due to energetic thermite/water interactions.

Debris in the Surtsey vessel was recovered from four basic locations: (1) from inside the subcompartment structures, i.e., inside the crane wall below the operating deck, (2) from the Surtsey vessel outside the structures, (3) from the cavity and instrument tunnel chute, and (4) from the crucible. Table 3.3 gives the debris recovery summary of the IET experiments. The total molten mass available for dispersal into the vessel is usually about 20 percent greater than the initial thermite charge due to the melting of the inner wall of the crucible, vaporization of the fusible brass plug, ablation of concrete in the cavity and structures, and oxidation of metallic debris.
The debris plume impacted the crane wall and on the bottom of the seal table room. Some of the debris entered the seal table room, and some of the debris was deflected to the containment basement floor. The concrete plug in the seal table room ceiling opening (i.e., in the operating deck) was ejected and dented a tank in the upper dome of the Surtsey vessel in IET-1. The concrete plug in the ceiling of the seal table room remained in place in IET-3, and thus, there was no transport pathway through the ceiling of the seal table room. This concrete plug was intentionally left out for all other tests. Debris was ejected through the opening in the ceiling of the seal table room into the upper dome. In addition, some debris was always ejected through the three doorways in the crane wall, around the steam generators, and through the triangular vent spaces above the reactor coolant pumps.

Because the concrete contaminants greatly influenced the quantity of recovered debris, the debris summaries were adjusted to account for the contaminants in the IET experiments where damage occurred to the cavity and vessel concrete structures. The concrete density was measured to be $1.92 \mathrm{~g} / \mathrm{cm}^{3}$. The total mass of concrete lost was based on the estimated volume loss. The debris recovery summary was adjusted assuming (1) all the concrete from the cavity was ejected into the Surtsey vessel, and (2) the concrete recovered in the vessel was proportionally distributed between the areas inside and outside the crane wall according to the debris recovered in those areas.

Table 3.3 also shows the mass balance based on transport fractions. The definitions for computing the transport fractions from the mass balance are also shown. The transport fractions depend on the mass recovered from the locations specified. For example, the mass transported to the upper dome, $\mathbf{M}_{\mathrm{d}, \mathrm{dome}}$, is computed from

$$
M_{d, \text { done }}=f_{\text {ejoct }} f_{\text {disp }} f_{\text {dome }} M_{d}^{o} \text {. }
$$


This method calculated (for all IET experiments) an amount of thermite transported to the upper dome that was less than the actual amount of material recovered in the upper dome. The difference represents contaminants and oxygen uptake. The transport fractions are computed based on the assumption that the bulk of contaminants and oxygen uptake occurred in the cavity, and that the initial thermite and additional masses are equally distributed. This introduces an element of subjectivity into the definition of transport fractions; however, the adopted procedure is recommended because it more closely represents the fraction of thermite dispersed to each location. For example, in IET-8B the method above predicts that $13.24 \mathrm{~kg}$ of thermite were transported to the upper dome, which is less than the $15.87 \mathrm{~kg}$ of material that were actually recovered in the upper dome.

A posttest sieve analysis of debris recovered from the Surtsey vessel outside the subcompartment structures was performed for all IET experiments. The particle size analysis discounted all debris with size $>9.4 \mathrm{~mm}$. The particle size distribution was usually lognormal. Table 3.4 gives the sieve mass median diameter with geometric standard deviation for all of the IET experiments. Figure 3.71 shows that in IET-8B the sieve mass median diameter of debris recovered outside the subcompartment structures was $0.42 \mathrm{~mm}$ with a geometric standard deviation of 5.2 .

\subsection{Energy Balance}

A single-cell equilibrium model was used to perform an energy balance on the IET experiments, neglecting the presence of water in the cavity. The single-cell equilibrium model is developed in Appendix A. Simple calculations based on the actual IET initial conditions were performed to determine the amount of energy that might be added to the Surtsey vessel atmosphere by the steam blowdown, exothermic steam/metal chemical reactions, debris/gas heat transfer, and hydrogen combustion. The total amount of energy was used to calculate an upper limit to the possible pressure increase in the Surtsey vessel, $\Delta \mathrm{P}_{\text {aquiniman. }}$. The result could then be compared to the measured peak pressure increase, $\Delta \mathrm{P}_{\text {memered, }}$ to determine the total DCH efficiency, $\eta=$

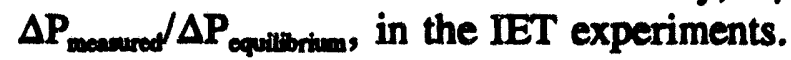

The presence of water in the cavity during the IET experiments provided a potential heat sink in the system, since some portion of the thermal and chemical energy in the debris would be used to vaporize the water. In the WC-2 experiment [Allen et al. 1992a], the results indicated that less than 15 percent of the water initially present in the cavity was vaporized, despite the fact that the thermite in that experiment contained approximately five times the amount of energy necessary to vaporize all of the water that was present. This result suggests that water was ineffective as a heat sink. Furthermore, the High-Pressure Melt Streaming (HIPS) tests with water in the cavity [Tarbell et al. 1991] suggest that the bulk of the water was ejected prior to debris dispersal. In the IET-8A and IET-8B experiments the thermite contained approximately the amount of energy necessary to vaporize all of the water that was present in the cavity. The actual amount of water that was vaporized in the IET experiments cannot be determined from the experimental results.

Derivation of the single-cell model has been documented by Pilch [1991]. The resulting model is given here. Thermal equilibrium between airborne debris and the containment atmosphere yields a simple, bounding expression for the DCH load,

$$
\frac{\Delta U}{U^{0}}=\frac{\Delta P}{P^{\circ}}=\frac{\sum_{i} \Delta E_{i}}{U^{0}(1+\psi)},
$$

where

$$
\begin{gathered}
\Delta \mathrm{U}=\text { total internal energy gained by } \\
\text { the containment atmosphere, }
\end{gathered}
$$




$$
\begin{aligned}
\mathrm{U}^{\circ}= & \text { initial internal energy of the } \\
& \text { entire containment atmosphere, } \\
\Delta \mathrm{P}= & \text { pressure rise in the containment } \\
& \text { resulting from the DCH event, } \\
\mathrm{P}^{\circ}= & \text { initial containment pressure, } \\
\Delta \mathrm{E}_{\mathrm{i}}= & \text { maximum energy that could be } \\
& \text { added to the containment } \\
& \text { atmosphere by the } \mathrm{i}^{\mathrm{t}} \text { process, } \\
& \text { where the } \mathrm{i} \text { processes are steam } \\
& \text { blowdown, debris/gas heat } \\
& \text { transfer, debris oxidation by } \\
& \text { steam in an otherwise inert } \\
& \text { atmosphere, and hydrogen } \\
& \text { combustion, and } \\
\psi= & \text { heat capacity ratio. }
\end{aligned}
$$

The heat capacity ratio appears because the debris still carries sensible heat that is not available for containment pressurization at thermal equilibrium between airborne debris and the atmosphere. The heat capacity ratio is defined by

$$
\psi=\frac{N_{d} C_{d}}{\left(N^{0}+N_{b}\right) C_{v}}
$$

where

$$
\begin{aligned}
& N_{d}=\text { number of } g \cdot \text { moles of debris } \\
& C_{d}=\text { molar heat capacity of debris, } \\
& \mathbf{N}^{\circ}=\text { number of gas } \mathrm{g} \cdot \text { moles initially } \\
& \text { in the containment, } \\
& N_{b}=\text { number of gas } g \cdot \text { moles added to } \\
& \text { the containment by RCS } \\
& \text { blowdown, and } \\
& C_{v}=\text { molar heat capacity of the }
\end{aligned}
$$

The $\mathrm{g} \cdot$ moles of debris participating in DCH can be expressed in terms of the initial charge of thermite by

$$
\mathbf{N}_{d}=f_{\text {ejert }} f_{\text {divp }} \frac{M_{d}^{0}}{M_{d}}
$$

where

$$
\begin{aligned}
& f_{\text {ciect }}=\text { fraction of the initial charge that } \\
& \mathrm{f}_{\text {dipp }}=\text { fraction of the melt ejected into } \\
& \begin{array}{c}
\mathbf{M}_{\mathbf{d}}^{\circ}=\begin{array}{l}
\text { initial (mass) charge of thermite, } \\
\text { and }
\end{array} \\
\text {. }
\end{array} \\
& \mathbf{M W}_{\mathrm{d}}=\text { the effective molecular weight of }
\end{aligned}
$$

Table 3.3 lists all the information necessary to complete this calculation.

Blowdown of the steam accumulator adds both mass and energy to the containment atmosphere. The maximum amount of energy that the accumulator can contribute to Surtsey pressurization is given by

$$
\Delta \mathrm{E}_{\mathrm{b}}=\frac{\mathrm{P}_{\mathrm{acc}}^{\circ} \mathrm{V}_{\mathrm{acc}}}{\gamma-1}\left[1-\frac{\mathrm{P}^{\circ}}{\mathrm{P}_{\mathrm{acc}}^{\circ}}\right),
$$

where

$$
\begin{aligned}
P_{a c c}{ }^{\circ}= & \begin{array}{l}
\text { equilibrium pressure of the ac- } \\
\text { cumulator/melt generator system } \\
\text { just prior to ping foilure, }
\end{array} \\
\mathrm{V}_{a c c}= & \text { total free volume of the accumu- } \\
& \text { lator and melt generator, and }
\end{aligned}
$$




$$
\gamma=\text { ratio of specific heats. }
$$

The term preceding the brackets represents the total internal energy of the accumulator, while the bracketed term represents the fraction of this total that is convected into the containment.

Molten debris dispersed from the reactor cavity carries both latent and sensible heat that can be transferred to the atmosphere. The maximum energy source associated with debris thermal energy,

$$
\Delta \mathrm{E}_{\mathrm{t}}=\mathrm{N}_{\mathrm{d}} \Delta \mathrm{e}_{\mathrm{t}}
$$

is equal to the amount of dispersed debris, $\mathbf{N}_{\mathrm{d}}$, times the specific molar internal energy of the debris, $\Delta e_{\text {, }}$, which has a value of $0.147 \mathrm{MJ} / \mathrm{g} \cdot$ mole for thermite.

The energy source due to debris oxidation,

$$
\Delta \mathrm{E}_{\mathrm{r}}=\mathrm{N}_{\mathrm{d}} \Delta \mathrm{e}_{\mathrm{r}},
$$

is equal to the amount of debris participating in DCH times the specific molar oxidation energy of the debris. Assuming all the metals react with steam, the specific molar oxidation energy, $\Delta e_{r}$, has a value of $0.054 \mathrm{MJ} / \mathrm{g} \cdot \mathrm{mole}$ for thermite. These values are specific to the thermite used in these experiments.

The energy source due to hydrogen combustion is

$$
\Delta \mathrm{E}_{\mathrm{H}_{2}}=\mathrm{N}_{\mathrm{H}_{2}, \text { ot }} \Delta \mathrm{e}_{\mathrm{H}_{2}}=\left(\mathrm{N}_{\mathrm{H}_{2}, \text { pre }}+\mathrm{U}_{\mathrm{H}_{2}} \mathrm{~N}_{\mathrm{d}}\right) \Delta \mathrm{e}_{\mathrm{H}_{2}}
$$

where

$$
\begin{aligned}
& \mathrm{N}_{\mathrm{H} 2, \mathrm{pre}}= \mathrm{g} \cdot \text { moles of preexisting hydrogen } \\
& \text { in the containment atmosphere } \\
& \text { prior to the DCH event, }
\end{aligned}
$$

$$
\begin{aligned}
\mathrm{U}_{\mathrm{HL}}= & \text { the effective stoichiometric } \\
& \text { coefficient for debris oxidation, } \\
& 0.892 \mathrm{~g} \cdot \text { moles- } \mathrm{H}_{2} / \mathrm{g} \cdot \text { mole- } \\
& \text { debris, and } \\
\Delta \mathrm{e}_{\mathrm{HD}}= & \text { the specific combustion energy } \\
& \text { for hydrogen, } 0.242 \mathrm{MJ} / \\
& \mathrm{g} \cdot \text { mole- }_{2} .
\end{aligned}
$$

The second term in the brackets, $\mathrm{U}_{\mathrm{H} 2} \mathbf{N}_{\mathrm{d}}$, represents the totals of $g \cdot$ moles of hydrogen that can be produced from complete oxidation of the metallic constituents of the dispersed debris. There is sufficient steam in the accumulator and water in the cavity or on the basement floor to achieve complete oxidation of debris.

The initial internal energy of the atmosphere is computed from

$$
U^{\circ}=N^{\circ} C_{v} T^{\circ}
$$

where

$$
\begin{aligned}
& T^{0}= \text { initial temperature of the Surtsey } \\
& \text { atmosphere. }
\end{aligned}
$$

It should be noted that this is a constant property equation of state with a reference temperature of zero.

Table 3.5 summarizes the energy balance for the IET experiments. The thermal (latent and sensible heats) and chemical energy (debris oxidation) are computed for the dispersed thermite mass only. The DCH efficiency for the IET tests are reported in the last row of Table 3.5. No energy balance was performed for IET-8A since there was no driving force. 


\section{Experimental Results}

Table 3.1 Summary of the results of the IET-2A, IET-2B, and IET-2C experiments

\begin{tabular}{|c|c|c|c|}
\hline I. & IET-2A & IET-2B & IET-2C \\
\hline Driving pressure at plug failure (MPa) & 6.1 & 5.8 & 1.7 \\
\hline Nondispersive cavity peak pressure (MPä) & 0.168 & 0.168 & 0.085 \\
\hline Moles of $\mathrm{H}_{2} \mathrm{O}$ driving gas (moles) & 464 & 418 & $\approx 0$ \\
\hline Ablated hole diameter $(\mathrm{cm})$ & 4.04 & 4.01 & 8.86 \\
\hline Total debris left in crucible (kg) & 5.95 & 7.86 & $-0.95^{+}$ \\
\hline Crucible east side exit peak temperature (K) & 2140 & 2082 & 2005 \\
\hline Crucible west side exit peak temperature (K) & 2288 & 2565 & 2475 \\
\hline Crucible bottom exit peak temperature (K) & N/A & 2575 & 2560 \\
\hline Thermite bum time (s) & 11.0 & 7.2 & 10.5 \\
\hline \multicolumn{4}{|c|}{$\begin{array}{l}\text { † Total debris left in the cavity is calculated using the difference between crucible postteet and pretest woights. } \\
\text { The difference was negative in IET-2C bocause, without the steam driving ges, the crucible steel liner (and } \\
\text { part of the MgO) was molted away and the molten thermite flowed out of the crucible under gravity instead of } \\
\text { being frozen in the crucible by the steam blowdown. }\end{array}$} \\
\hline
\end{tabular}


Table 3.2 Hydrogen results for the IET experiments

\begin{tabular}{|c|c|c|c|c|c|c|c|c|c|}
\hline 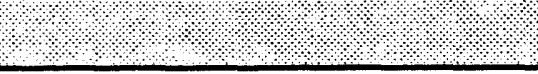 & IET-1 & IET-1R & IET-3 & IET-4 & IET-5 & IET-6 & IET-7 & IET-8A & IET-8B \\
\hline \multicolumn{10}{|l|}{ Oxygen $(g \cdot$ moles $)$} \\
\hline - Pretest & 2 & 15 & 656 & 702 & 318 & 681 & 683 & 700 & 700 \\
\hline \multicolumn{10}{|l|}{ Hydrogen $(\mathrm{g} \cdot \mathrm{moles})$} \\
\hline $\begin{array}{l}\text { - Pretest } \\
\text { (mol. \%) }\end{array}$ & $\mathbf{0}$ & $\mathbf{0}$ & $\mathbf{0}$ & 0 & $\begin{array}{c}202 \\
2.76 \\
\end{array}$ & $\begin{array}{r}180 \\
2.59 \\
\end{array}$ & $\begin{array}{l}283 \\
3.97 \\
\end{array}$ & $\begin{array}{r}308 \\
4.33 \\
\end{array}$ & $\begin{array}{l}288 \\
3.91 \\
\end{array}$ \\
\hline - Produced $(30 \mathrm{~min})^{1}$ & 233 & 248 & 227 & 303 & 319 & 319 & 274 & 176 & 299 \\
\hline - Burned (30 min) ${ }^{9}$ & 3 & 11 & 190 & 240 & 53 & 345 & 323 & 154 & 281 \\
\hline - Posttest (30 min) & 230 & 238 & 37 & 63 & 468 & 154 & 234 & 330 & 306 \\
\hline$\Delta \mathrm{P}$ due to the HPME (kPa) & 98 & 110 & 246 & 262 & 103 & 279 & 271 & 87 & 244 \\
\hline
\end{tabular}

1 The IET-8A posttest results and the hydrogen produced and burned analyses was obtained from data acquired at 900 minutes. 
Table 3.3 Debris recovery summary for the IDT experinents

\begin{tabular}{|c|c|c|c|c|c|c|c|c|c|}
\hline Mass balance (kg) & IET-1 & IET-1R & IET-3 & ET-4 & IET-5 & ET-6 & IET-7. & IET-8A & IET-8B \\
\hline Initial Thermite Charge, $\AA^{\circ}$ (a) & 43.0 & 43.0 & 43.0 & 43.0 & 43.0 & 43.0 & 43.0 & 43.0 & 43.0 \\
\hline Crucible (b) & 4.54 & 4.63 & 4.50 & 4.76 & 2.60 & 2.27 & 6.74 & 0.23 & 2.56 \\
\hline Cavity/Chute (c) & 7.06 & 13.19 & 16.80 & 9.54 & 20.07 & 8.47 & 13.31 & 42.31 & 5.55 \\
\hline Inside Structures (d) & 38.03 & 32.41 & 31.30 & 32.67 & 31.23 & 36.60 & 33.99 & 5.81 & 26.99 \\
\hline Outside Structures (e) & 4.98 & 3.80 & 3.00 & $8.04^{*}$ & 1.89 & 5.871 & 2.71 & 2.76 & 15.87 \\
\hline Total Recovered & 54.61 & 54.03 & 55.60 & 55.02 & 55.79 & 53.21 & 56.75 & 51.11 & 50.97 \\
\hline \multicolumn{10}{|l|}{ Transport fractions } \\
\hline $\begin{array}{l}\text { Ejected into Cavity, } \\
\mathrm{f}_{\text {cject }}=1-\mathrm{b} / \mathrm{a}\end{array}$ & 0.894 & 0.892 & 0.895 & 0.889 & 0.939 & 0.947 & 0.843 & 0.995 & 0.940 \\
\hline $\begin{array}{l}\text { Dispersed from Cavity, } \\
f_{d i s}=(d+e) /(c+d+e)\end{array}$ & 0.859 & 0.733 & 0.671 & 0.810 & 0.623 & 0.834 & 0.734 & 0.168 & 0.885 \\
\hline $\begin{array}{l}\text { Debris Transported Outside } \\
\text { Subcompartment, }\end{array}$ & 0.116 & 0.105 & 0.111 & 0.197 & 0.057 & 0.138 & 0.074 & 0.322 & 0.370 \\
\hline
\end{tabular}

$f_{\text {dam }}=e /(d+e)$

* The molten mass available for dispersal into the vessel is usually about $20 \%$ greater then the initial iron oxide/ahminum/chromium thermito charge dus to melting of the immer wall of the crucible, vaporization of the fusible brass plug, ablation of concrete in the cavity, and oxidation of metallic debris by steam.

* The crane wall inside the seal table room failed in IET-4. This resulted in an additional flowpeth outside of the structures.

1 The cavity floor and seal table room floor suffered significant damage in IET-6. This may have resulted in additicanl thermile trameport onteide of the structures. 
Table 3.4 Sieve mass median diameter for the IET experiments IET-1 IET-1R IET-3 IET-4 IET-5 IET-6 IET-7 IET-8A IET-8B

\begin{tabular}{lccccccccc}
\hline $\begin{array}{l}\text { Sieve mass median } \\
\text { diameter (mm) }\end{array}$ & 0.36 & 0.24 & 0.18 & 0.52 & 0.09 & 0.65 & 0.28 & 0.25 & 0.42 \\
$\begin{array}{l}\text { Geometric standard } \\
\text { deviation }\end{array}$ & 6.5 & 9.4 & 17.5 & 7.7 & 6.8 & 8.9 & 6.4 & 2.9 & 5.2 \\
\hline
\end{tabular}


Table 3.5 Energy balance for the IET experiments

\begin{tabular}{llcccccccc}
\hline \multicolumn{1}{c}{ Term } & \multicolumn{1}{c}{ Description } & IET-1 & IET-1R & IET-3 & IET-4 & IET-5 & IET-6 & IET-7 & IET-8B \\
\hline$\Delta \mathrm{E}_{\mathrm{b}}(\mathrm{MJ})$ & Blowdown energy & 6.44 & 5.69 & 5.52 & 6.07 & 5.41 & 5.70 & 5.32 & 5.70 \\
$\Delta \mathrm{E}_{\mathrm{i}} \mathrm{1}^{\prime}(\mathrm{MJ})$ & Latent and sensible heat & 82.8 & 70.5 & 58.8 & 67.5 & 62.7 & 85.1 & 66.7 & 89.7 \\
$\Delta \mathrm{E}_{\mathrm{r}}(\mathrm{MJ})$ & Chemical energy & 21.1 & 18.0 & 15.2 & 17.2 & 16.1 & 21.7 & 17.0 & 22.9 \\
$\Delta \mathrm{E}_{\mathrm{HL}}(\mathrm{MJ})$ & Hydrogen combustion & 0 & 0 & 74.2 & 83.8 & 127 & 150 & 152.0 & 176 \\
$\mathrm{C}_{\mathrm{d}}(\mathrm{J} / \mathrm{g} \cdot$ mole-K) & Debris heat capacity & 74.7 & 74.7 & 74.7 & 74.7 & 74.7 & 74.7 & 74.7 & 74.7 \\
$\mathrm{C}_{\mathrm{v}}(\mathrm{J} / \mathrm{g} \cdot$ mole-K) & Atmosphere heat capacity & 24.10 & 24.10 & 24.10 & 24.10 & 30.93 & 24.20 & 24.16 & 24.42 \\
$\psi$ & Heat capacity ratio & 0.20 & 0.172 & 0.145 & 0.158 & 0.117 & 0.214 & 0.165 & 0.224 \\
$\mathrm{U}^{\circ}(\mathrm{MJ})$ & Atmosphere internal energy & 52.1 & 52.1 & 49.8 & 52.4 & 66.8 & 51.8 & 52.4 & 52.7 \\
$\mathrm{P}^{\circ}(\mathrm{MPa})$ & Atmosphere initial pressure & 0.20 & 0.20 & 0.19 & 0.20 & 0.20 & 0.198 & 0.201 & 0.203 \\
$\Delta \mathrm{P}(\mathrm{MPa})$ & Calculated pressure rise & 0.353 & 0.309 & 0.516 & 0.575 & 0.568 & 0.826 & 0.792 & 0.911 \\
$\eta(\%)$ & DCH efficiency & 27.8 & 35.6 & 47.7 & 45.6 & 18.1 & 33.8 & 34.2 & 26.8 \\
\hline
\end{tabular}




\section{Experimental Results}

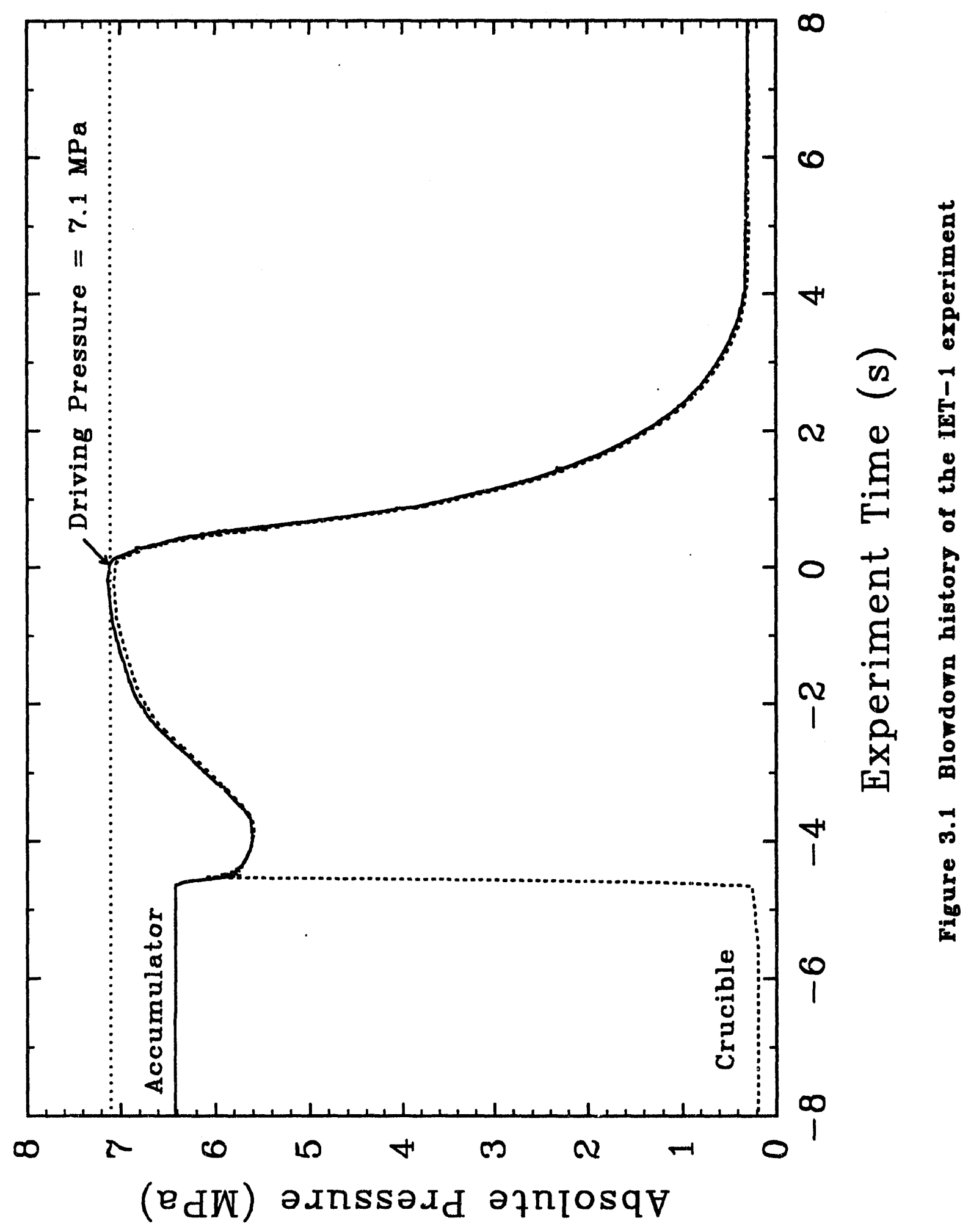


孞

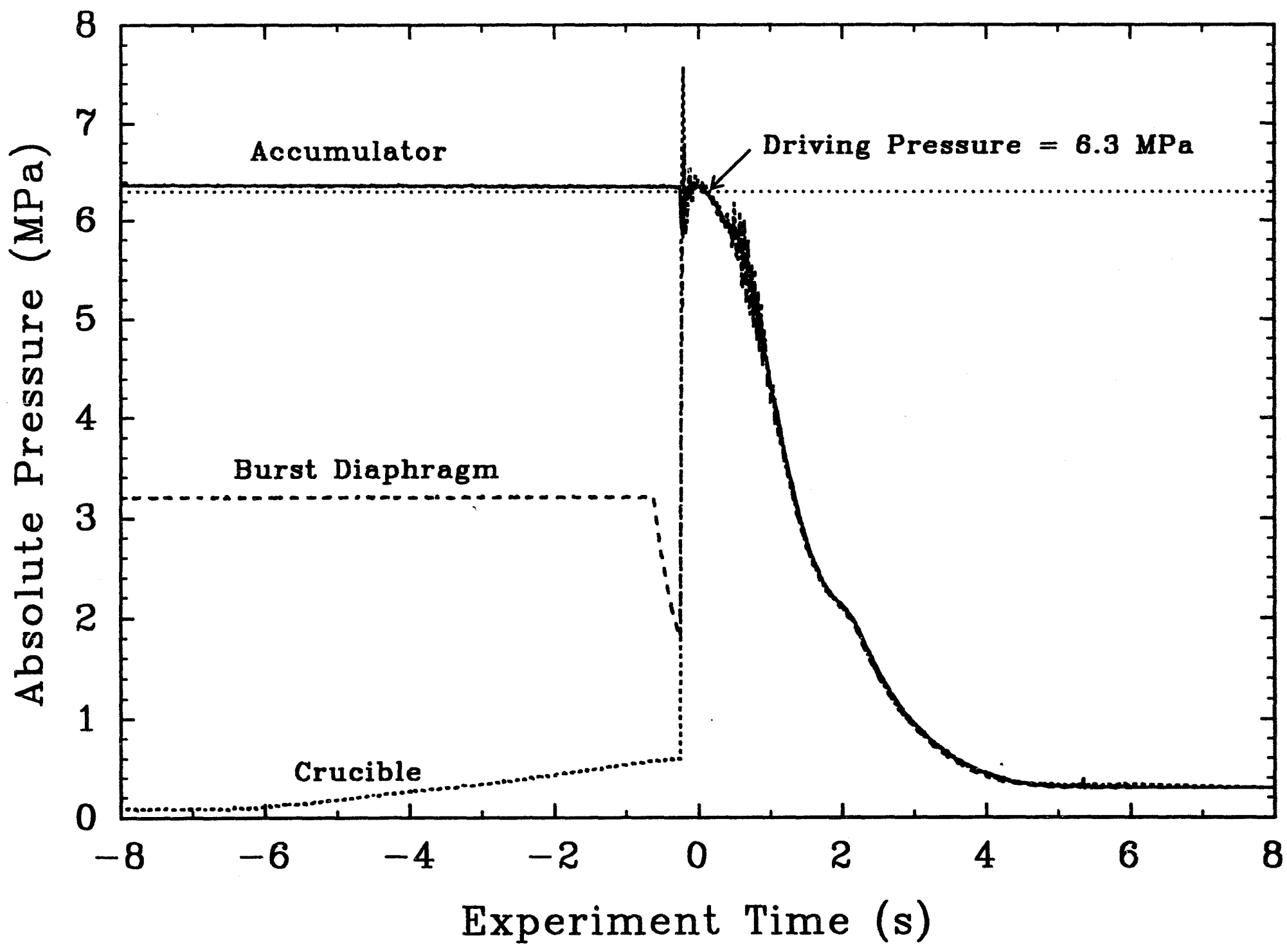

Figure 3.2 Blowdown history of the IET-1R experiment 


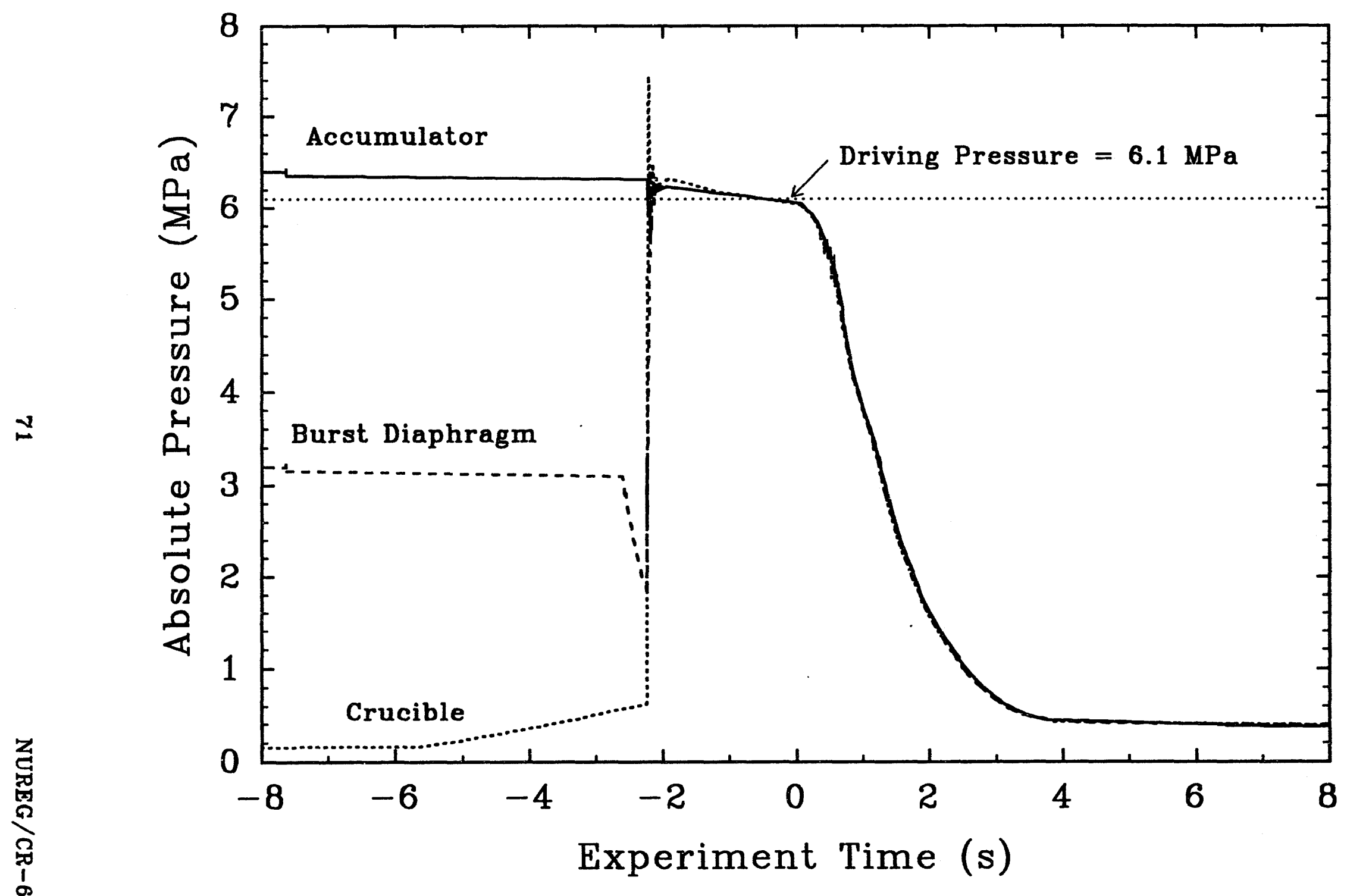

Figure 3.3 Blowdown history of the IET-3 experiment 
忌

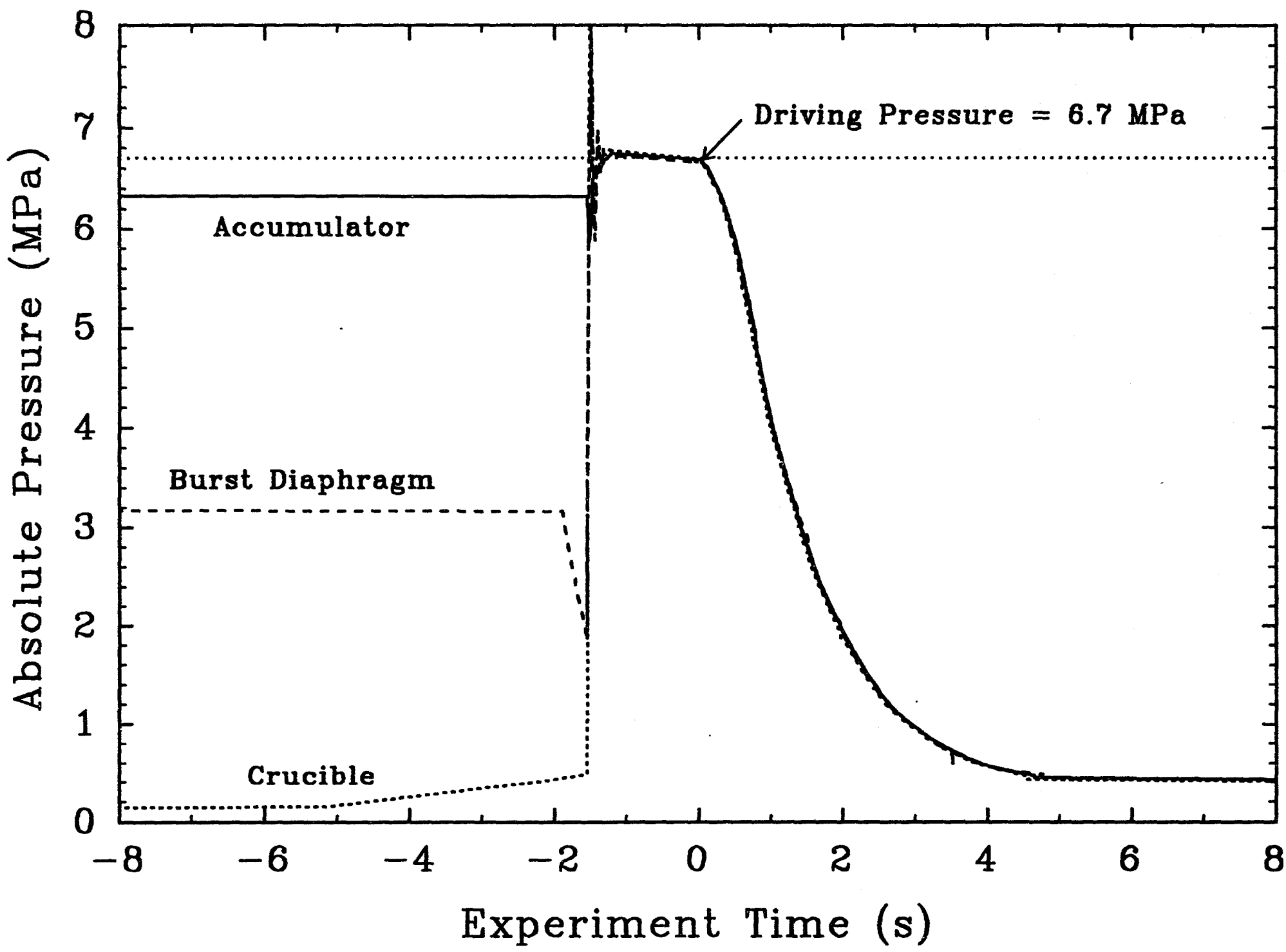

Figure 3.4 Blowdown history of the IET-4 experiment 


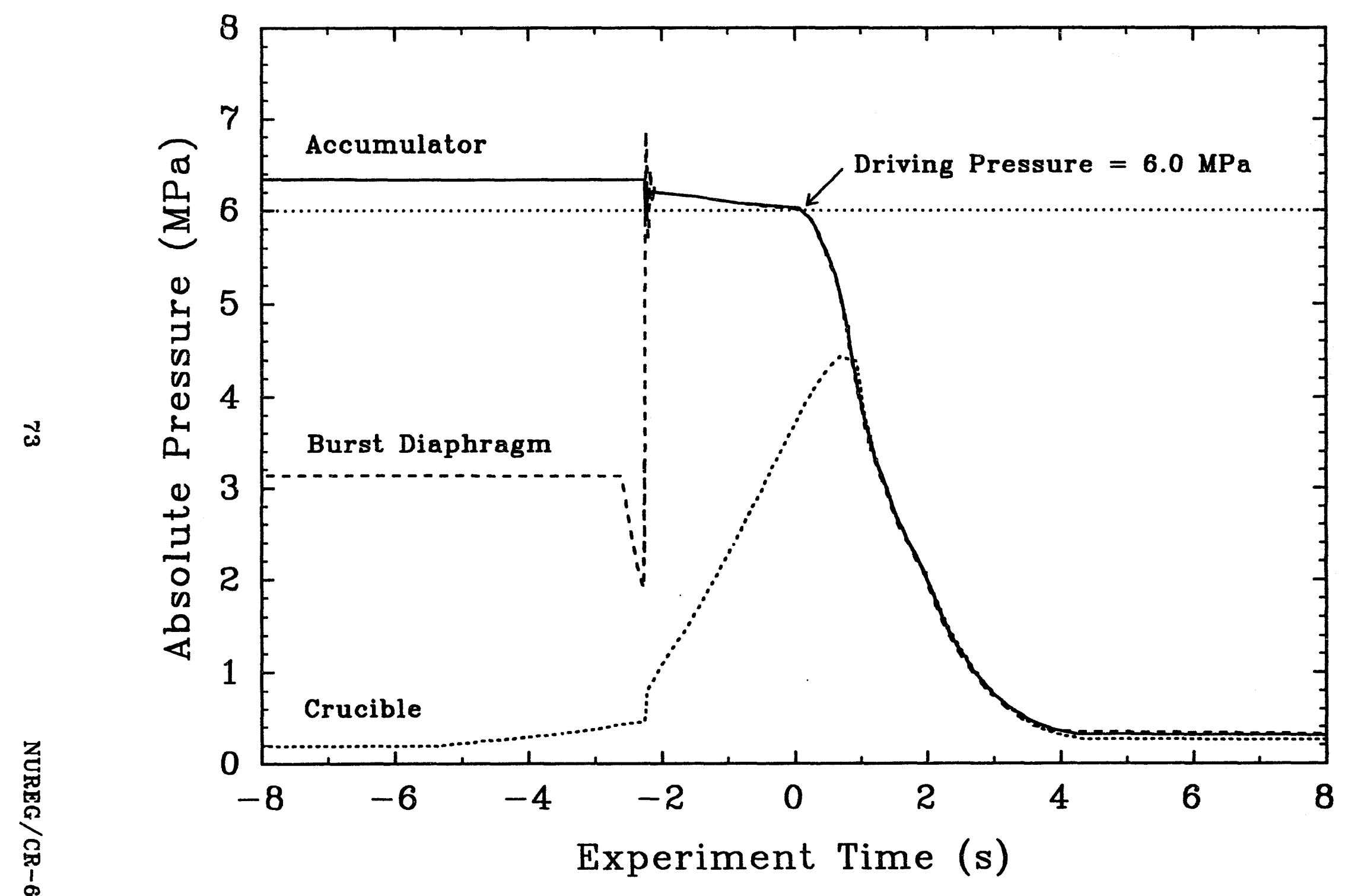

Figure 3.5 Blowdown history of the IET-5 experiment 


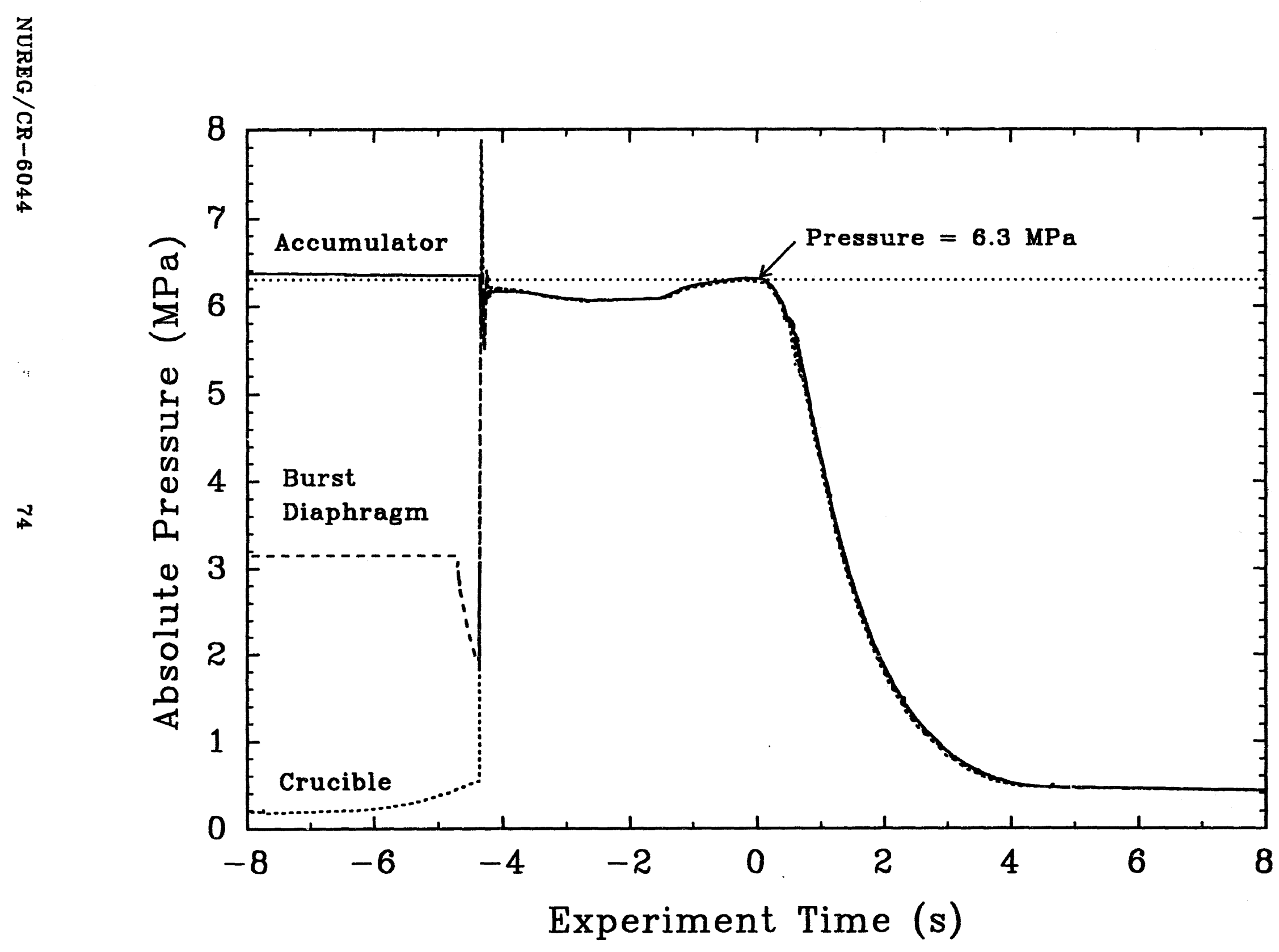

Figure 3.6 Blowdown history of the IET-6 experiment 


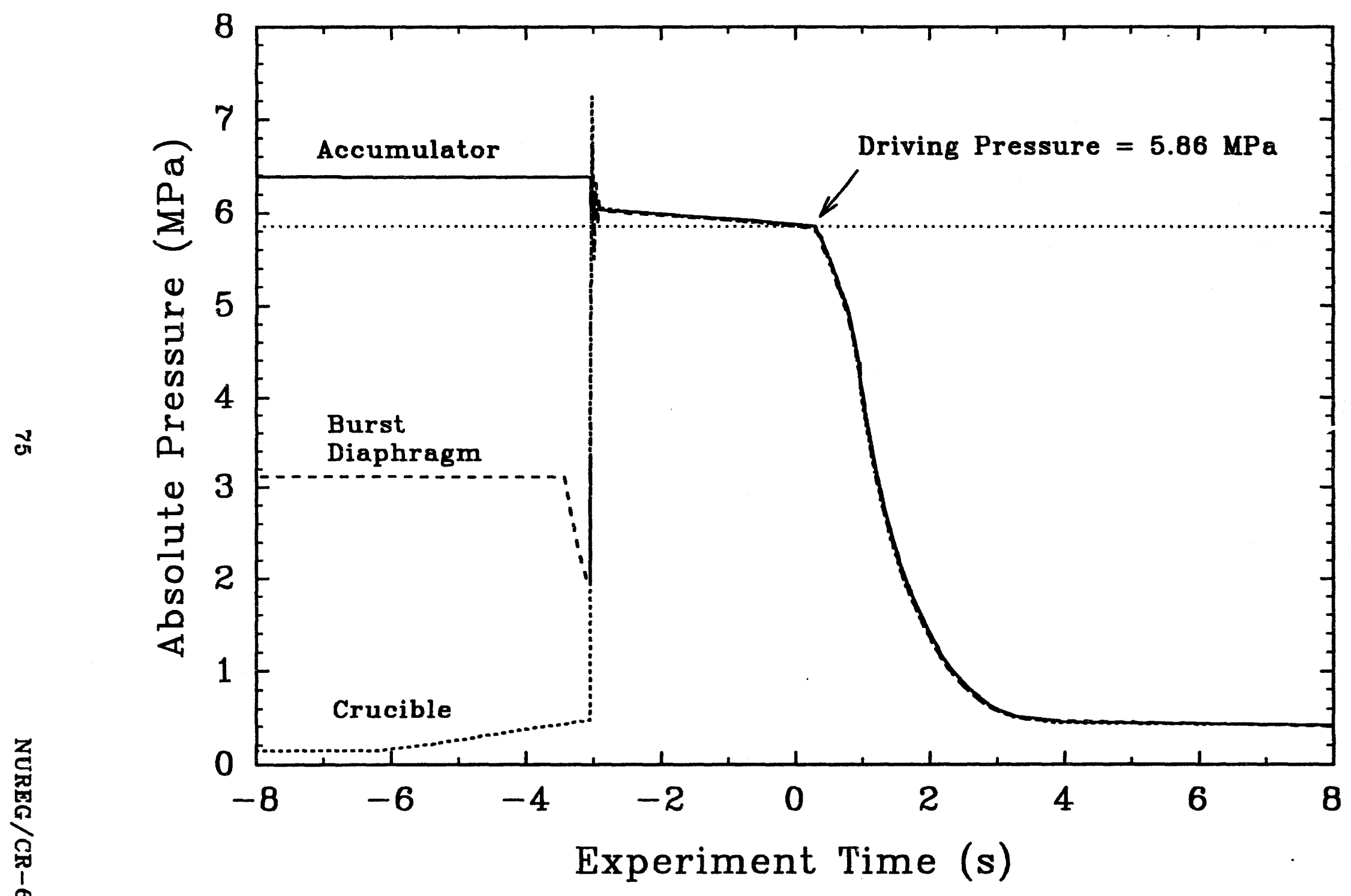

Figure 3.7 Blowdown history of the IET-7 experiment 


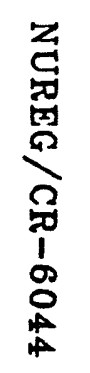

o

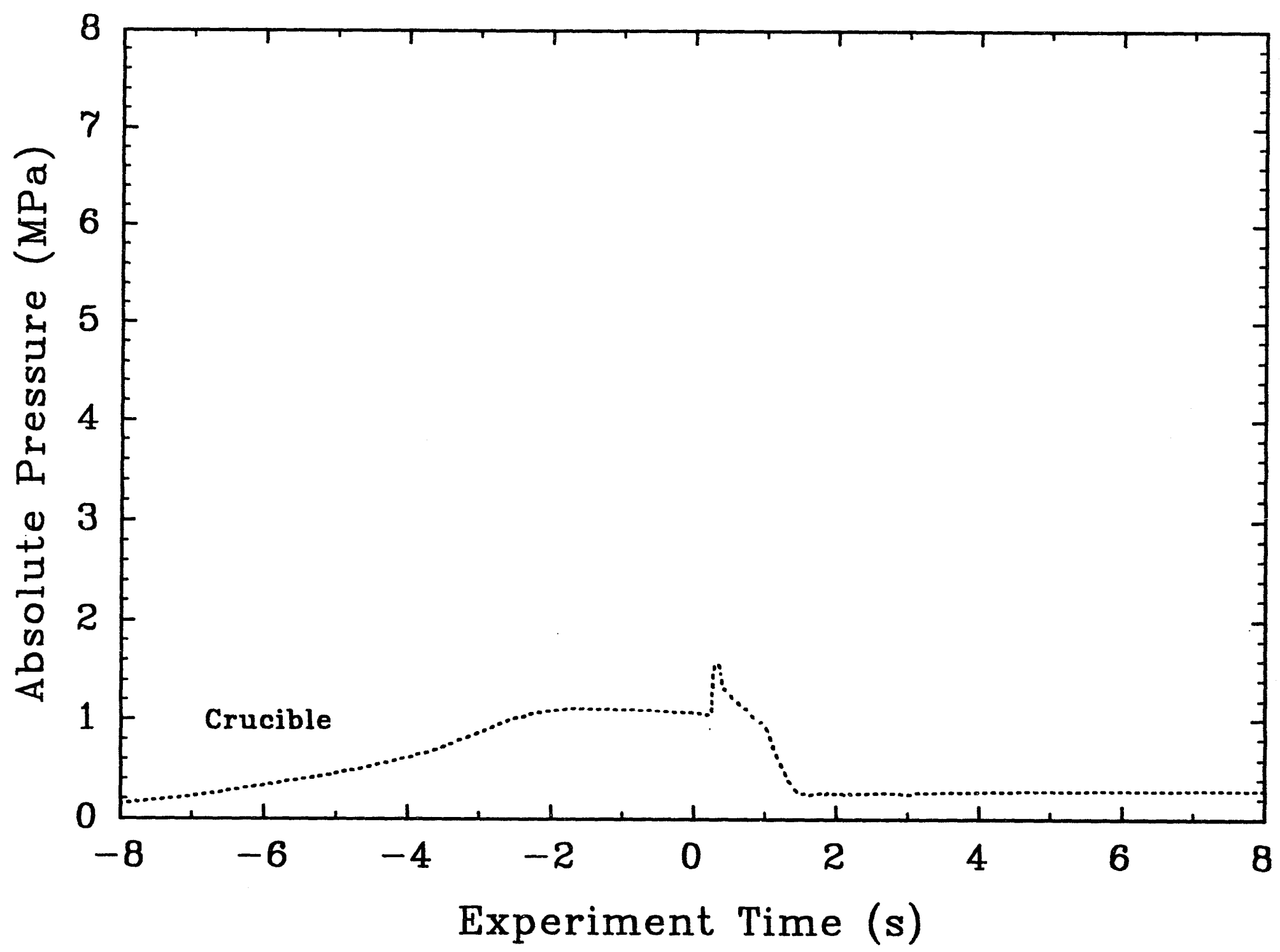

Figure 3.8 Blowdown history of the IET-BA experiment 


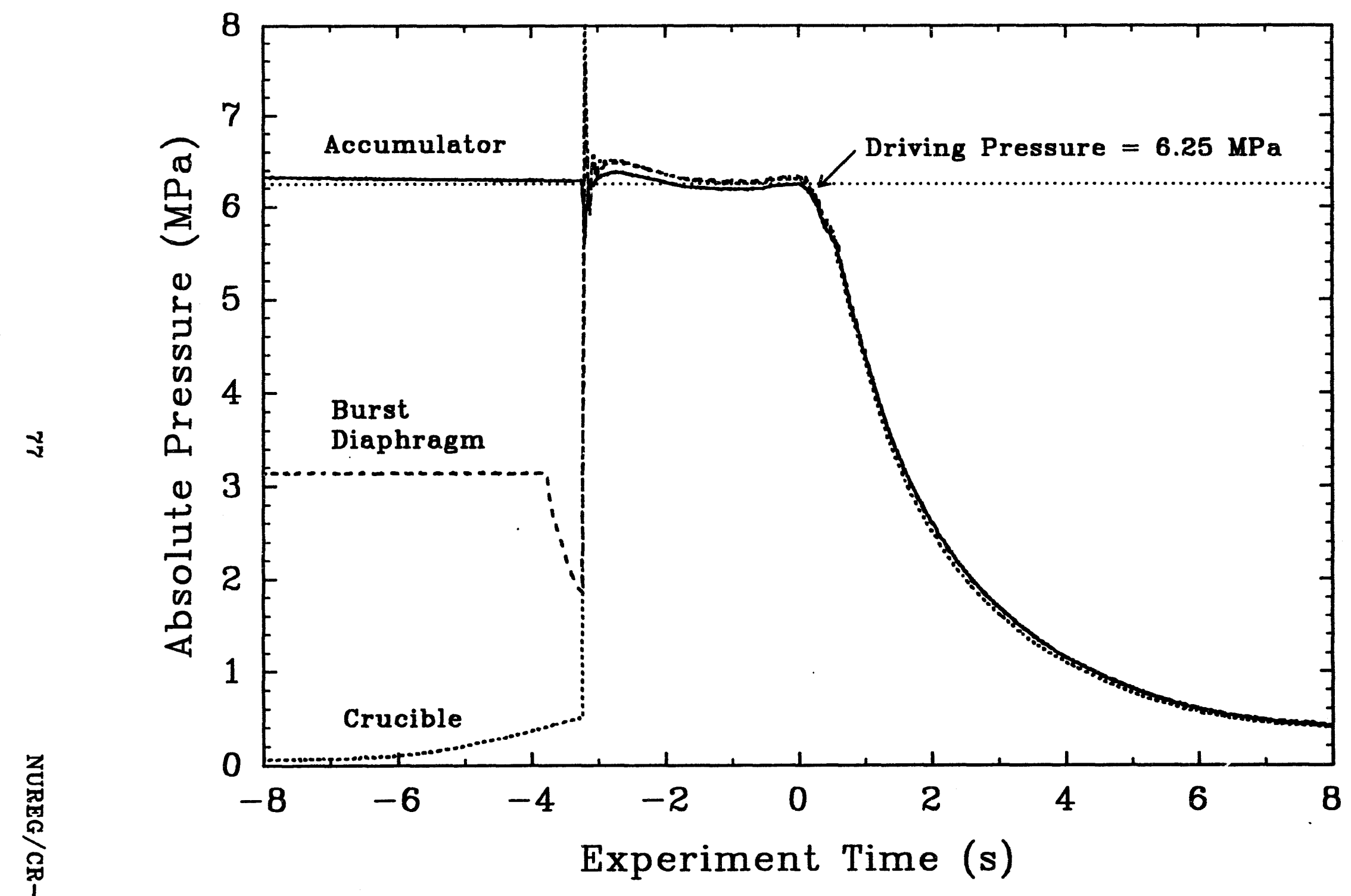

Figure 3.9 Blowdown history of the IET-8B experiment 


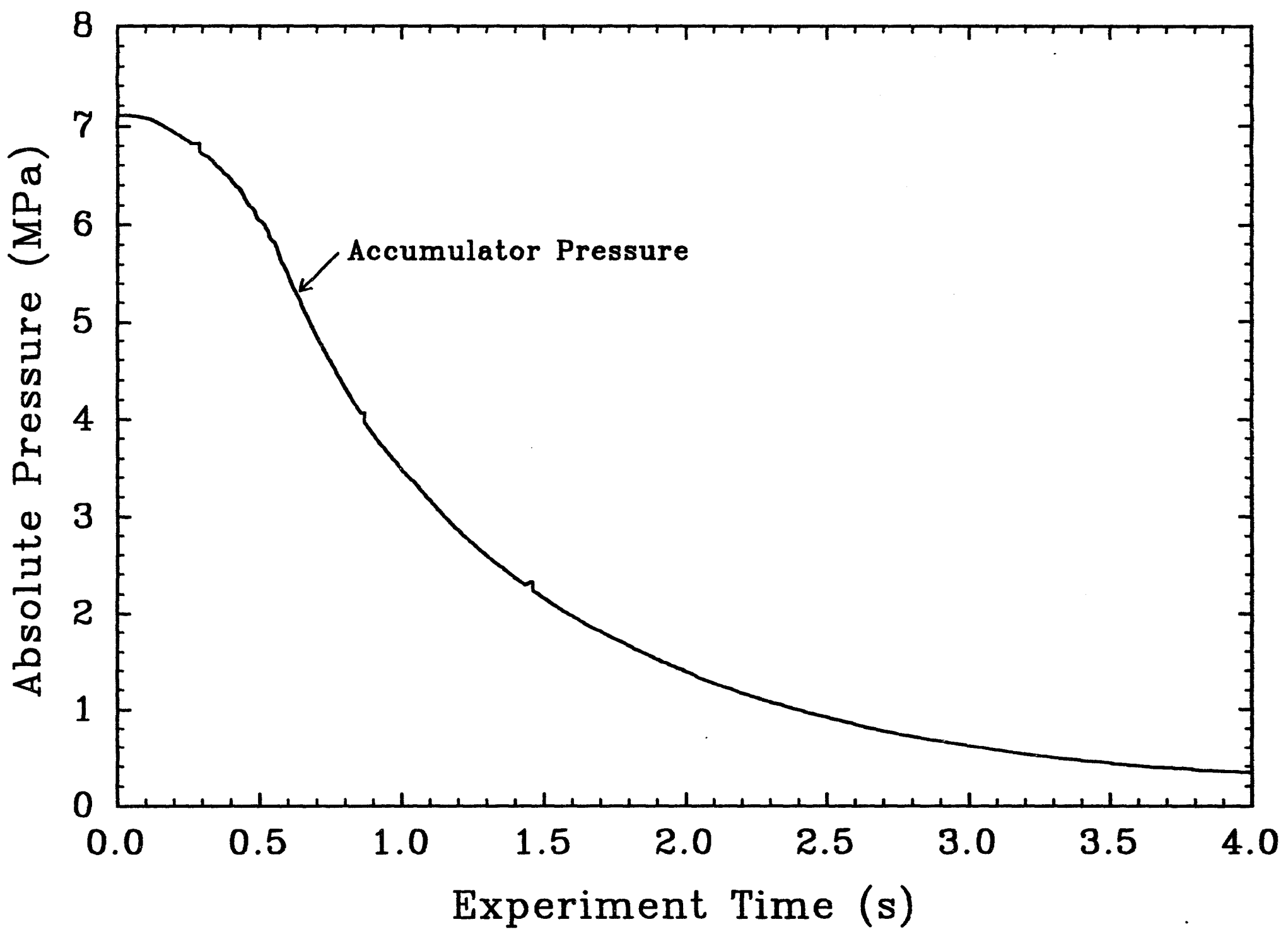

Figure 3.10 Blowdown pressure in the IET-1 experiment 


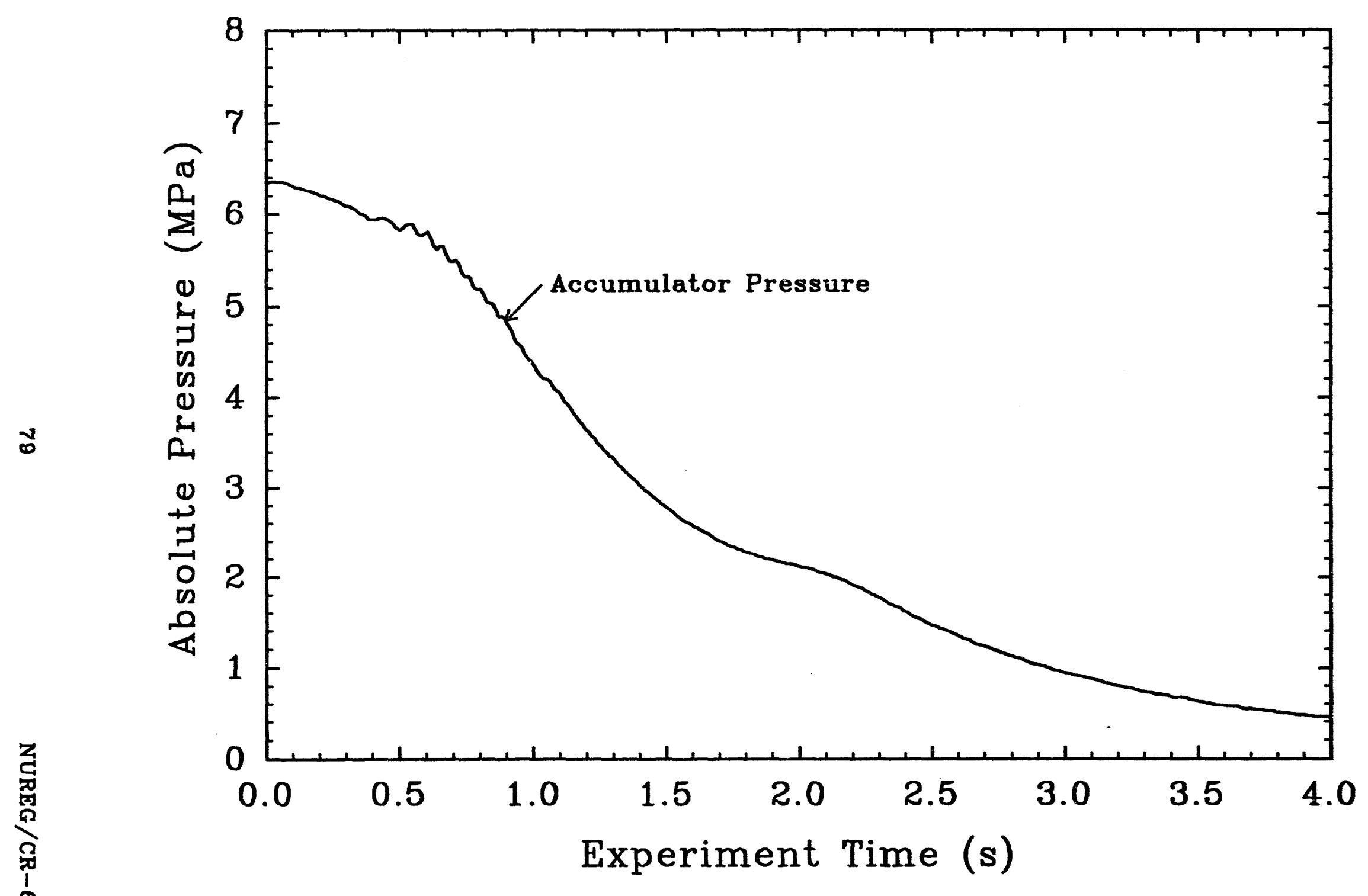

Figure 3.11 Blowdown pressure in the IET-1R experiment 


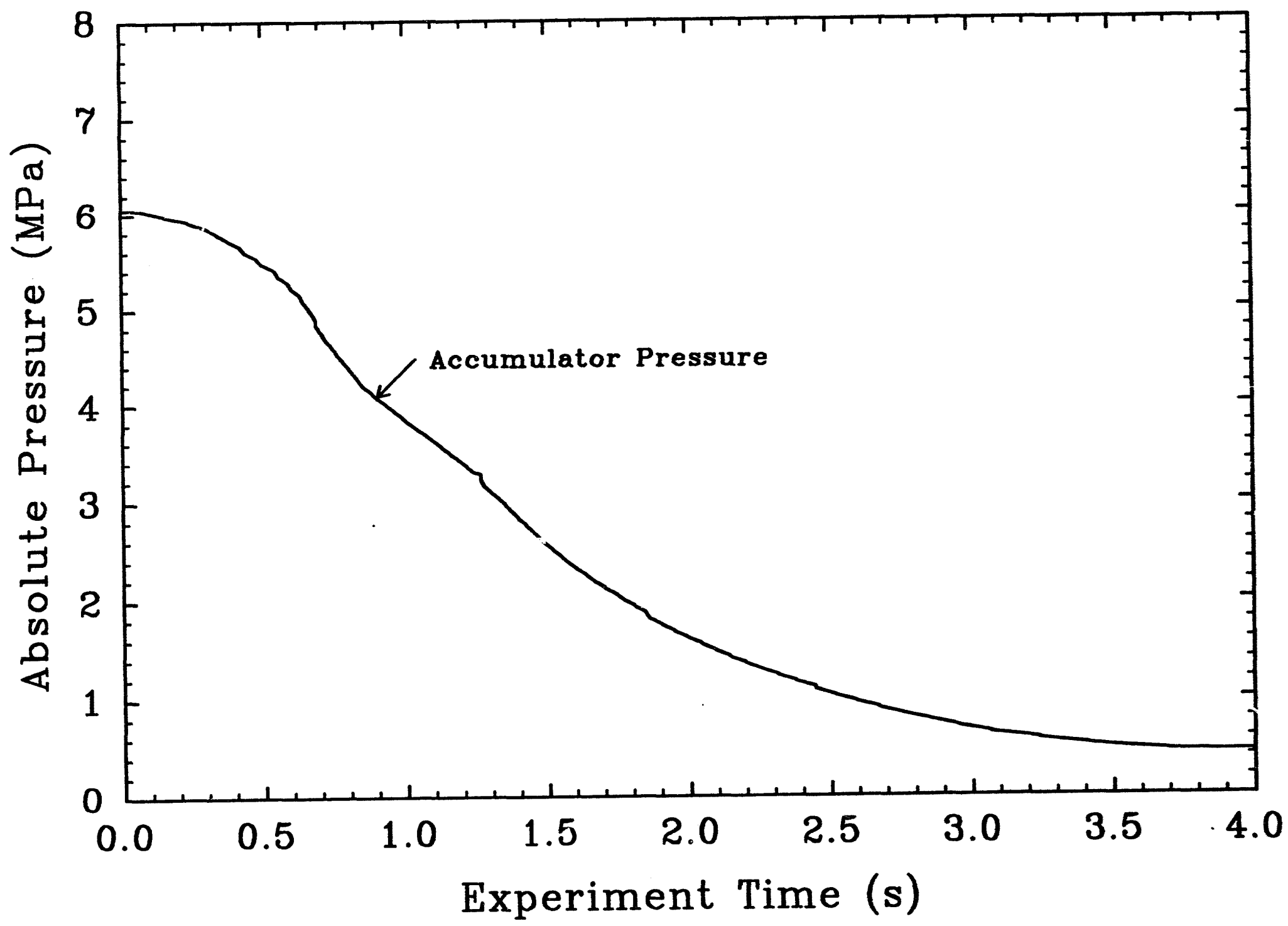

Figure 3.12 Blowdown pressure in the IBT-3 experiment 


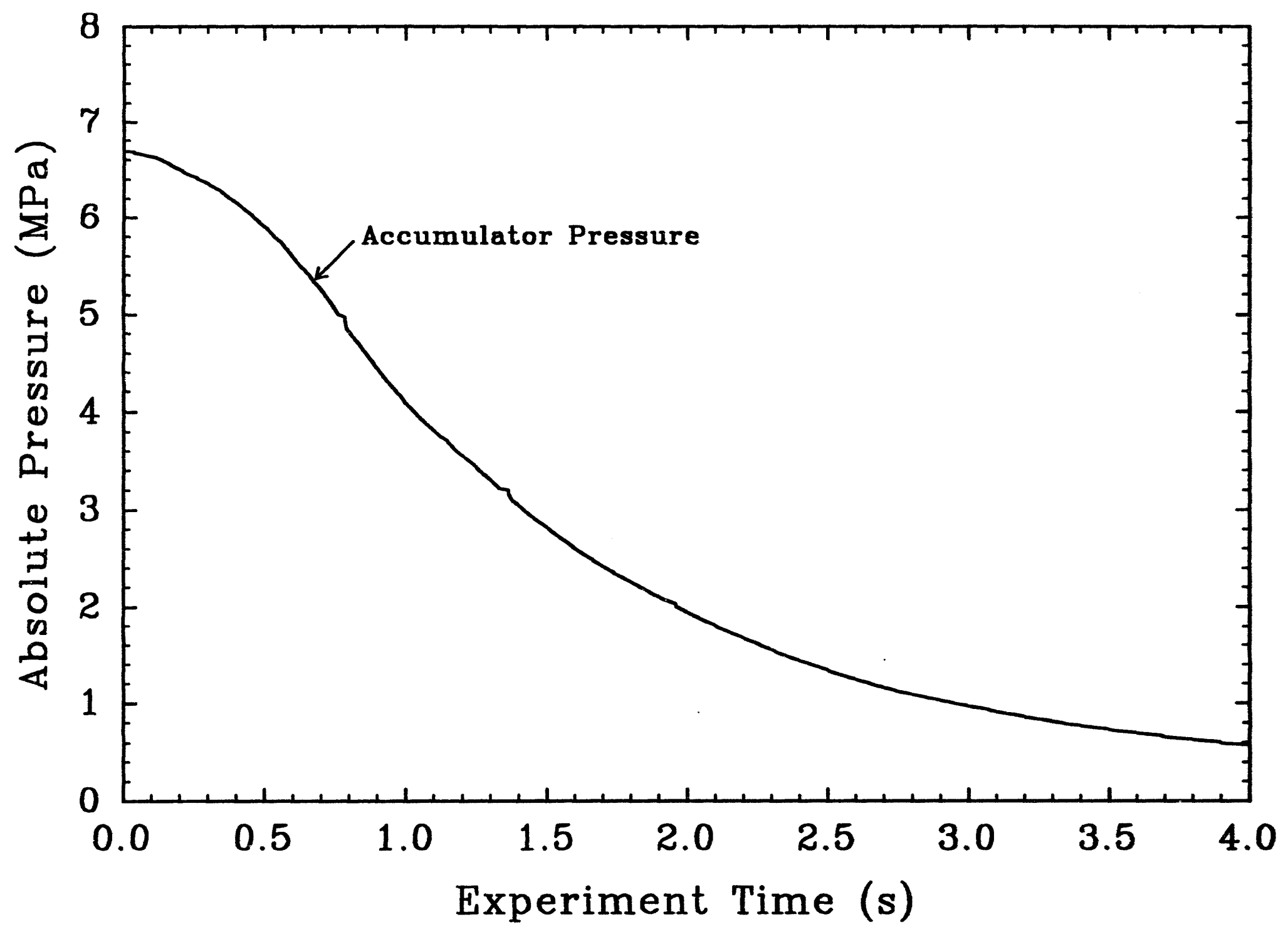

Figure 3.13 Blowdown pressure in the IET-4 experiment 


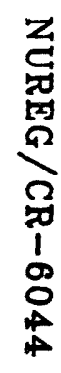

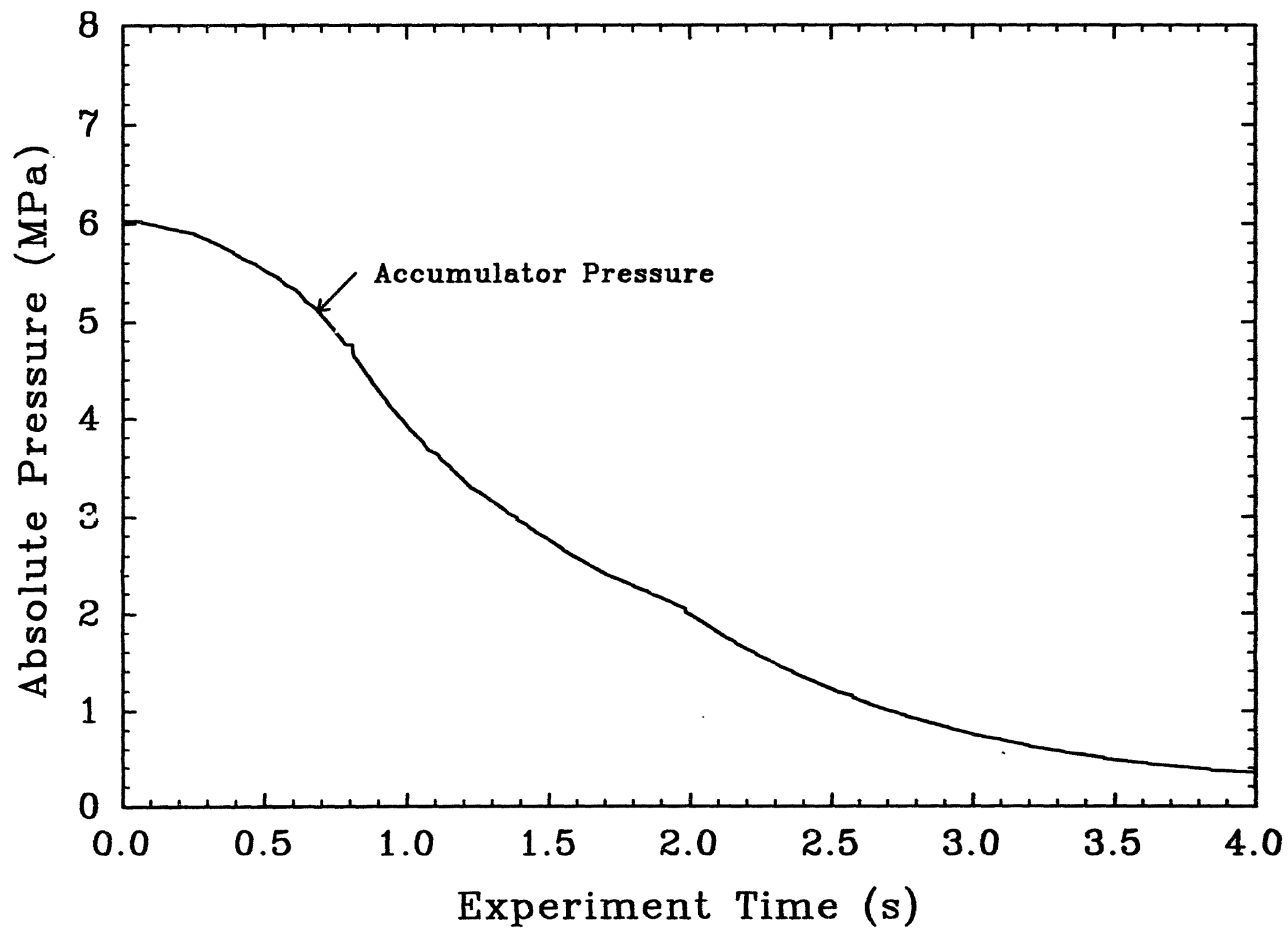

줌

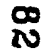

Figure 3.14 Blowdown pressure in the IBT-5 experiment 

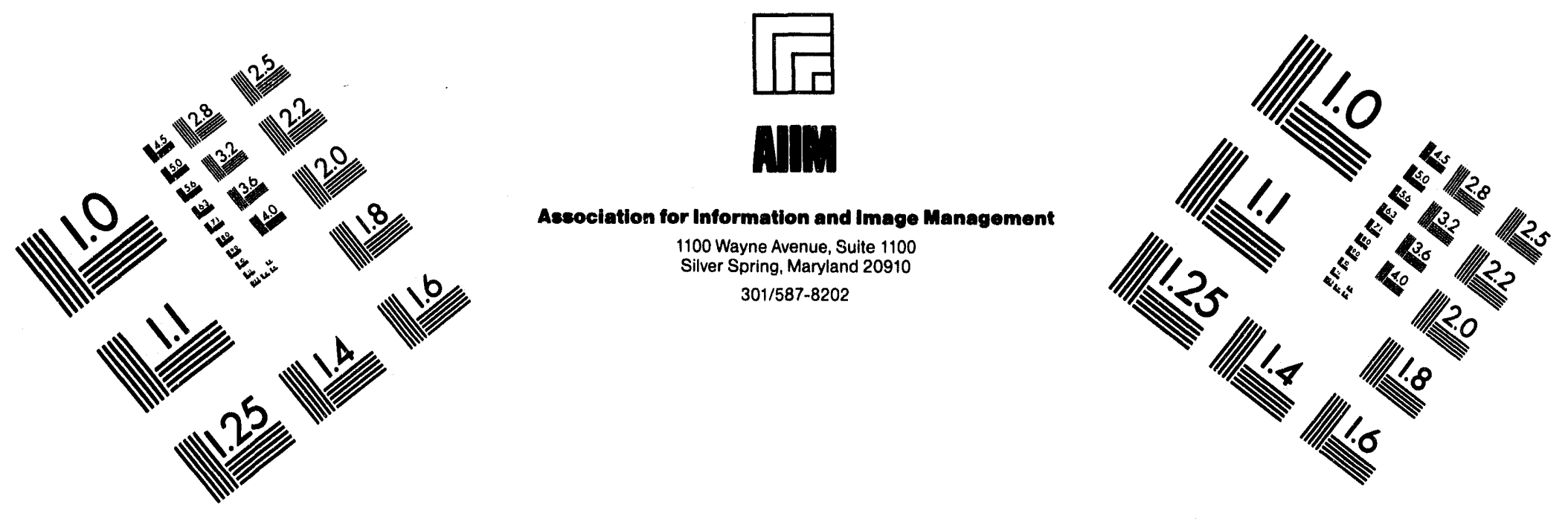

\section{Centimeter}

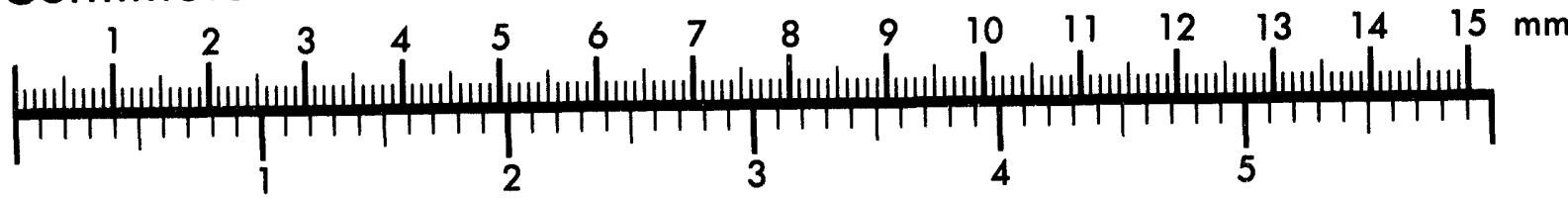

Inches
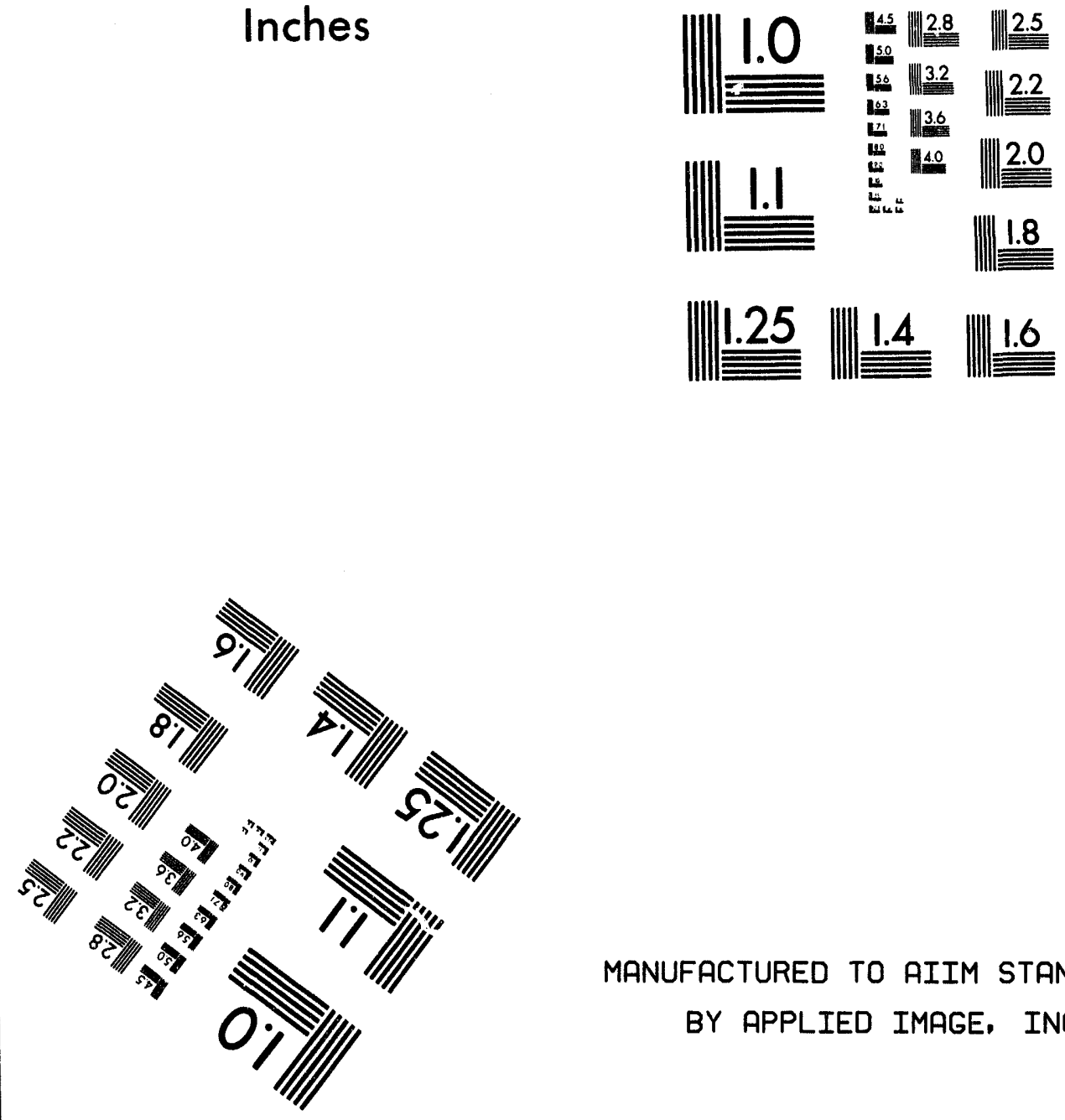

MANUFACTURED TO AIIM STANDARDS

BY APPLIED IMAGE, INC.

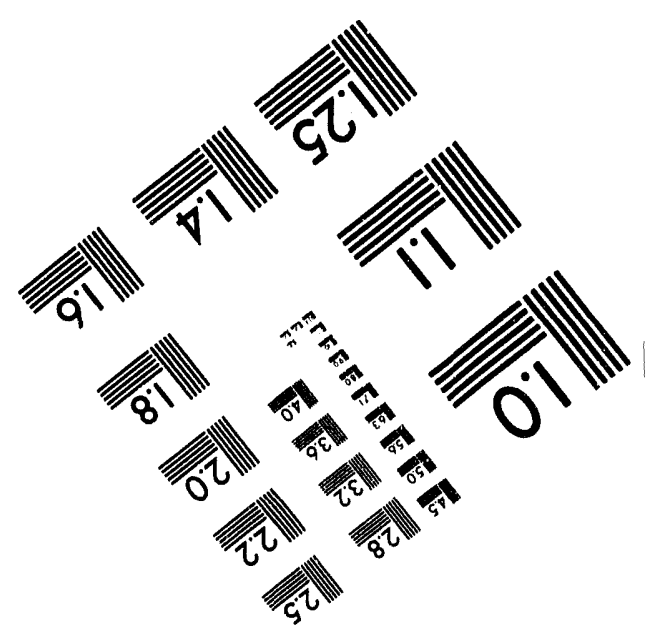



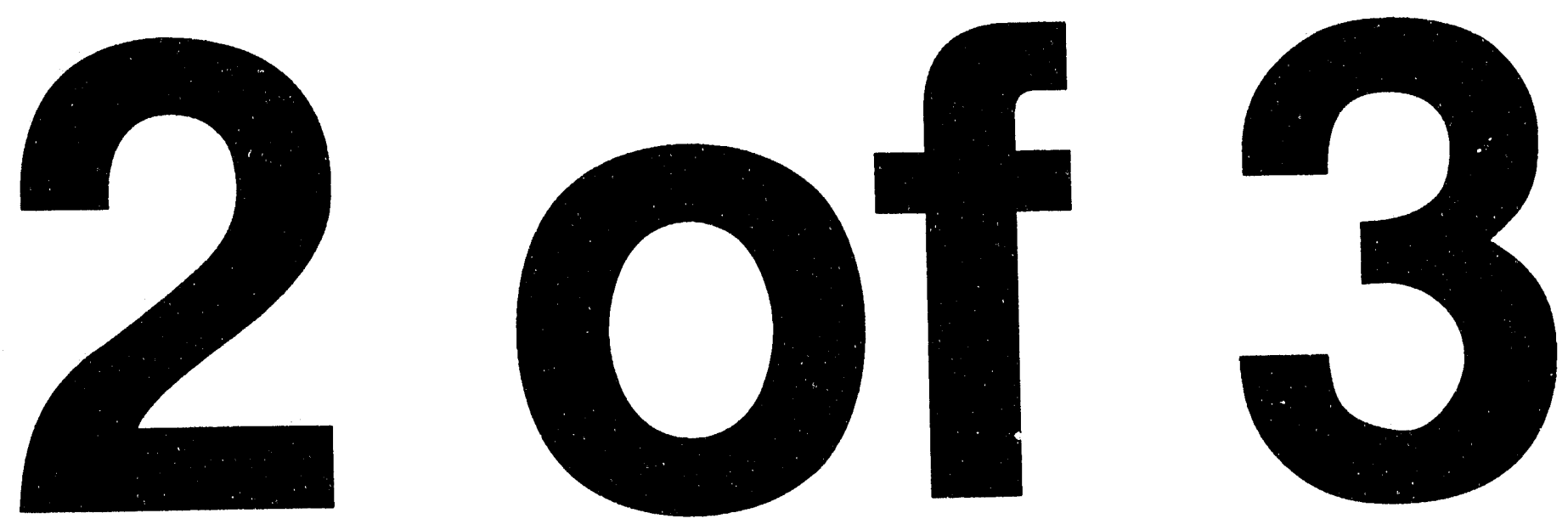


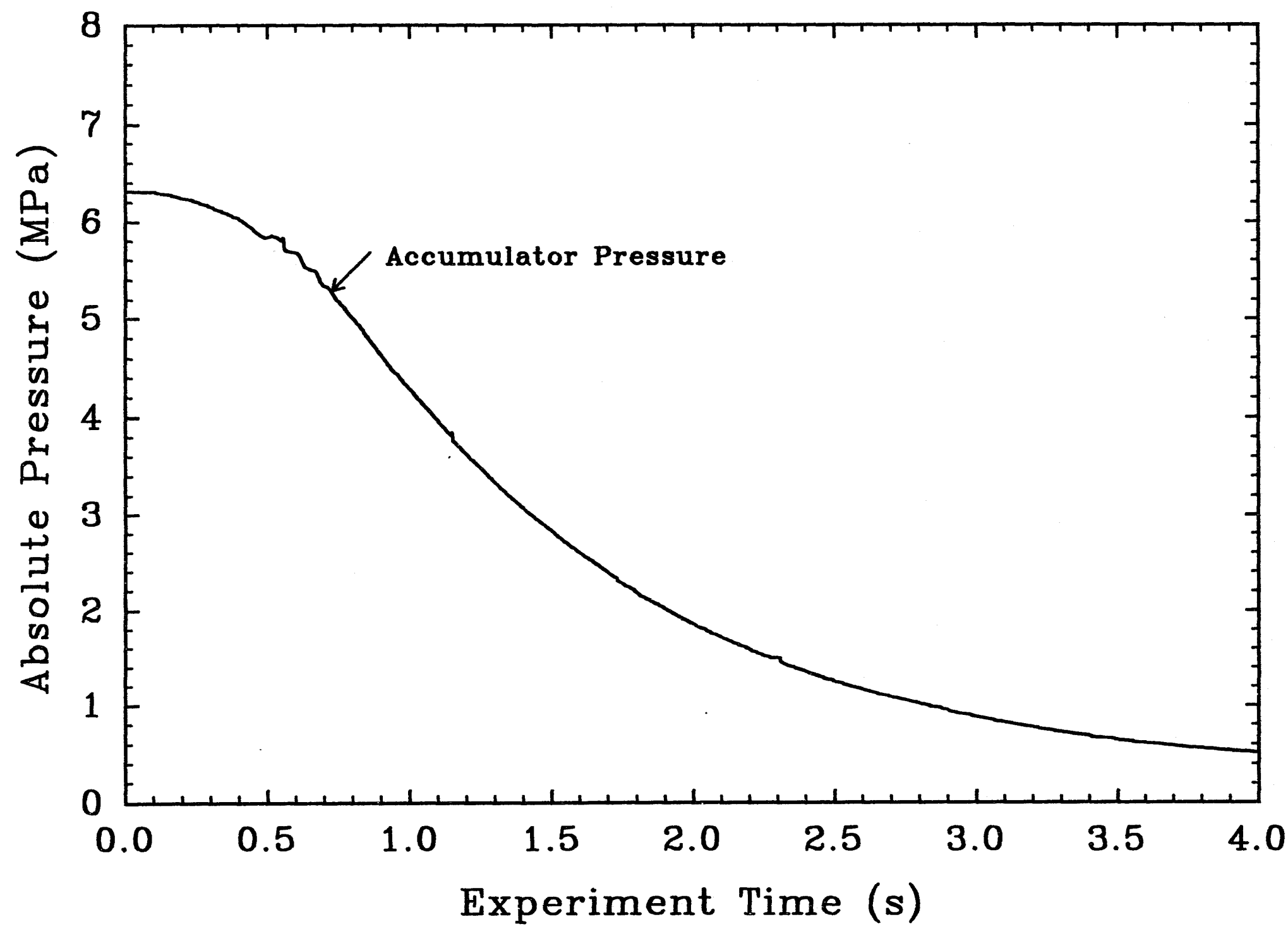

Figure 3.15 Blowdown pressure in the IET-6 experiment 


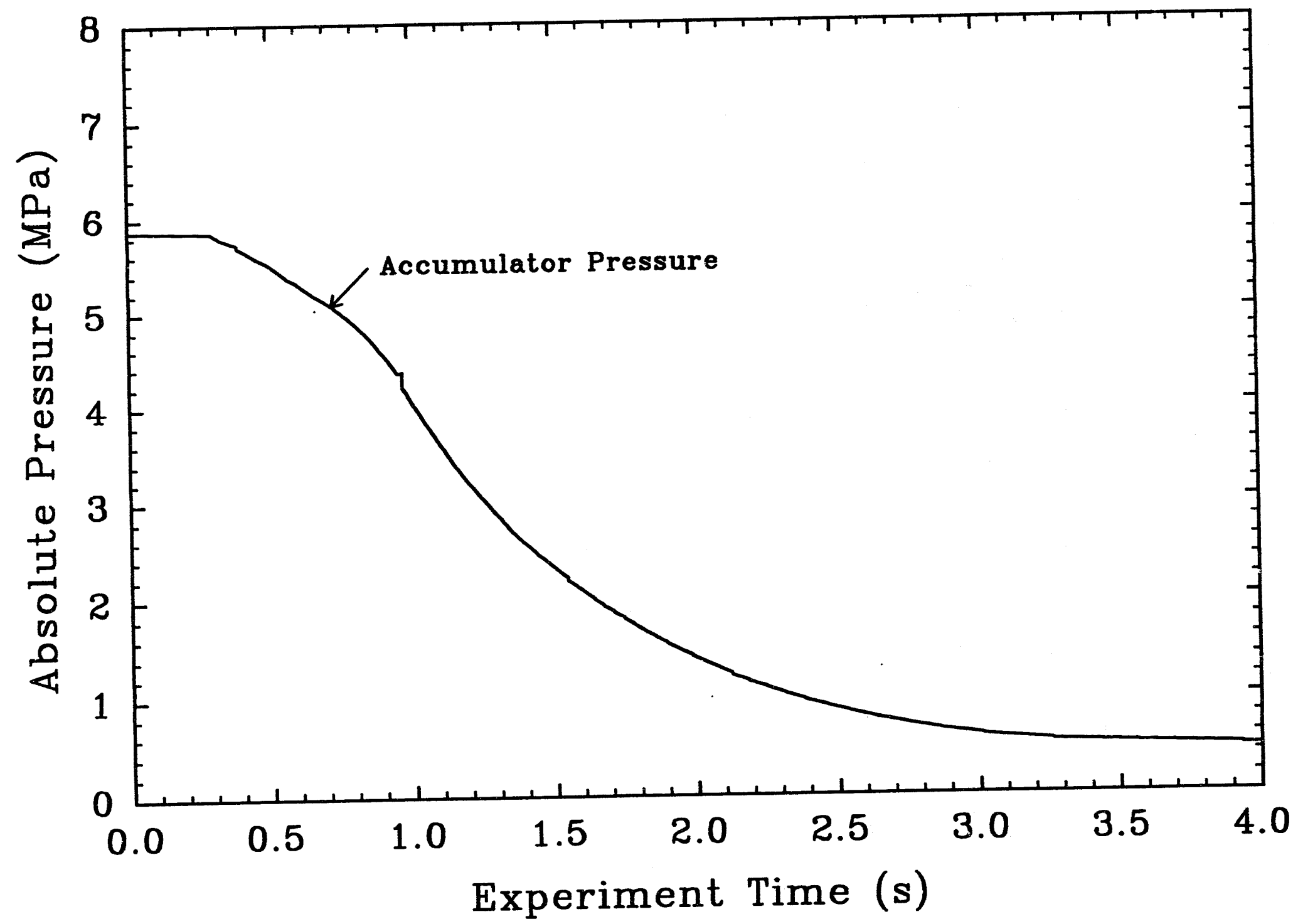

Figure 3.16 Blowdown pressure in the IET-7 experiment 


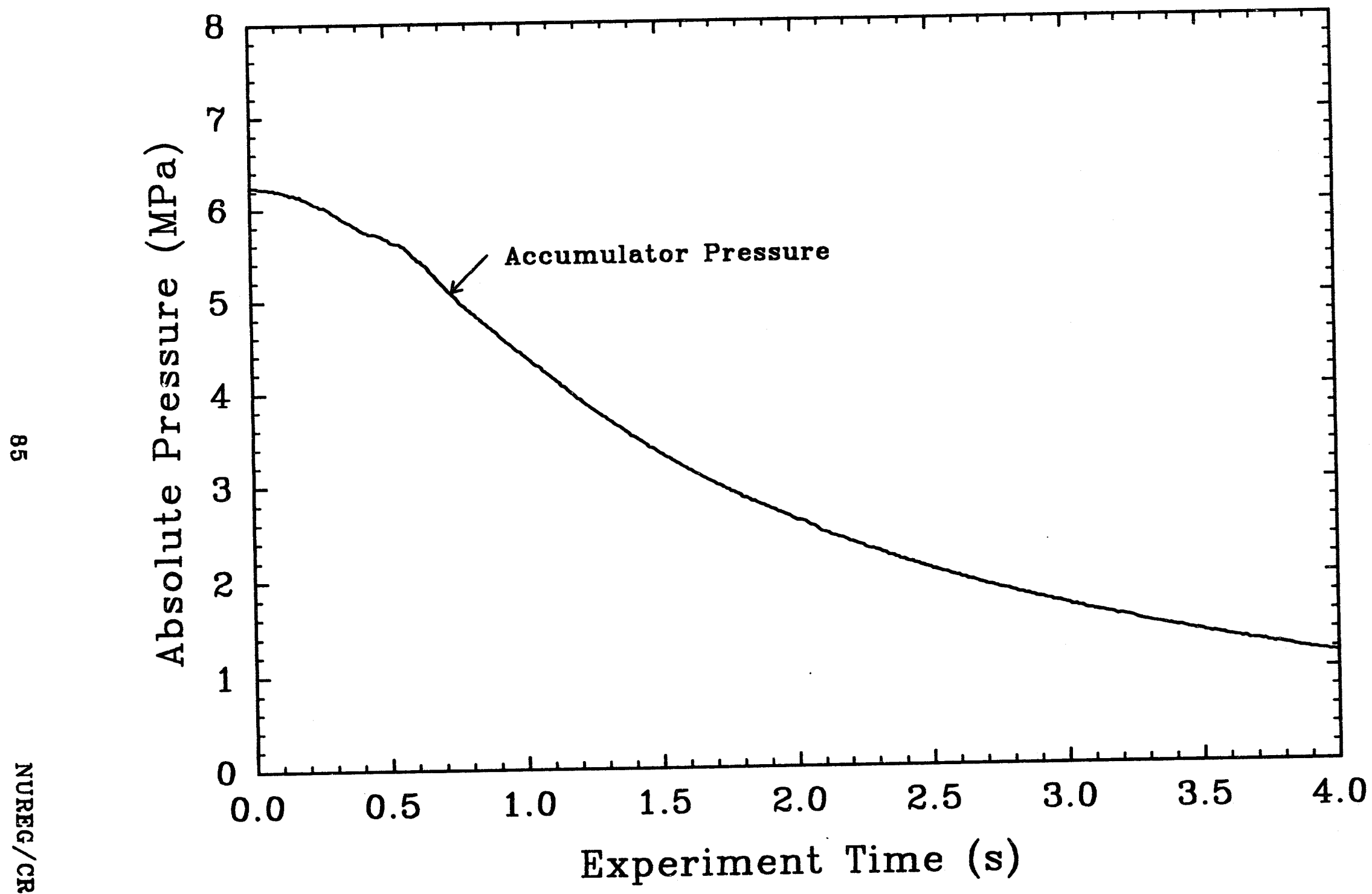

Figure 3.17 Blowdown pressure in the IET - 8B experiment 


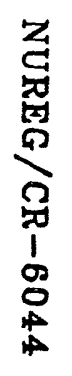

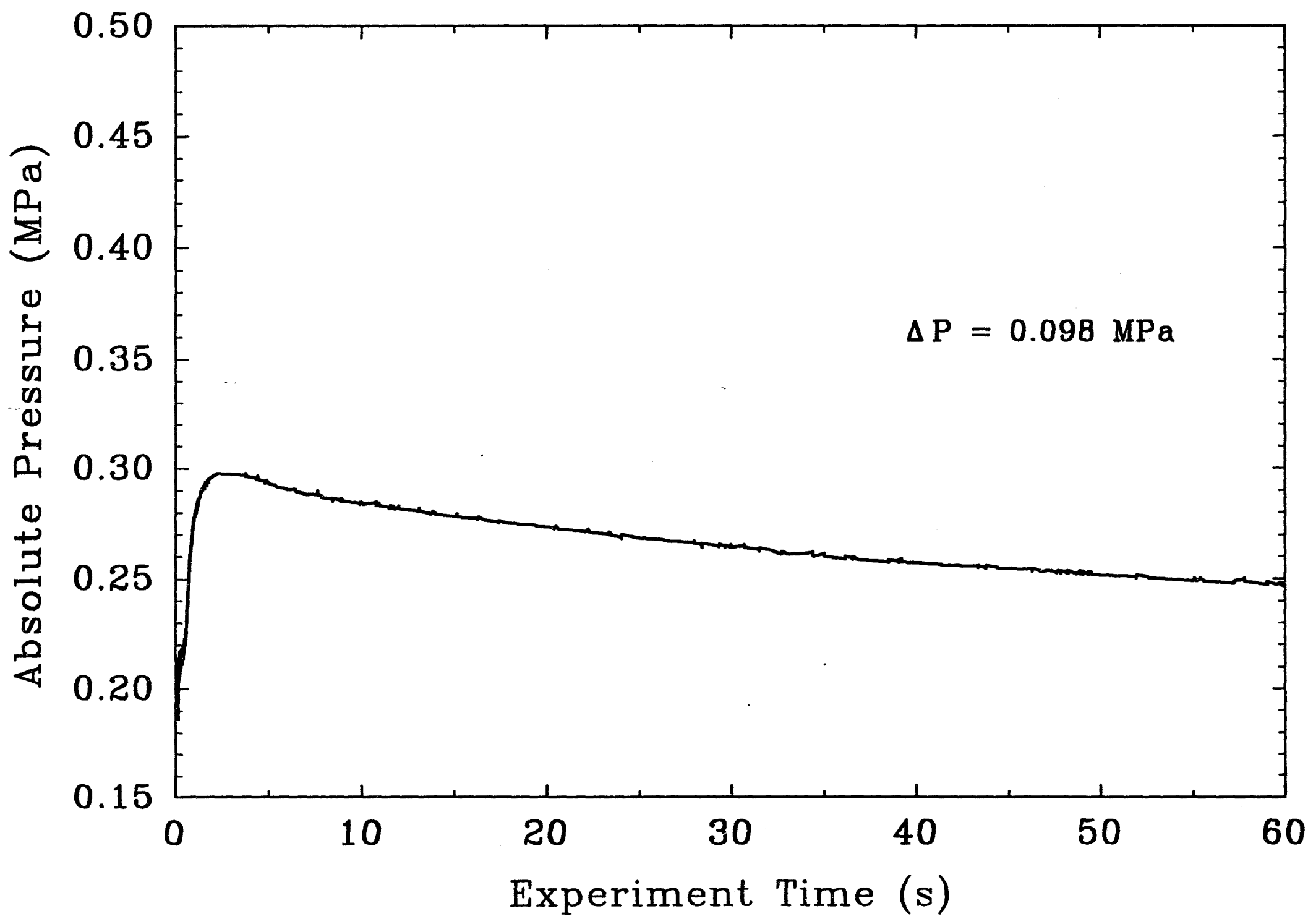

Figure 3.18 Surtsey vessel presaure versus time in the IET-1 experiment 


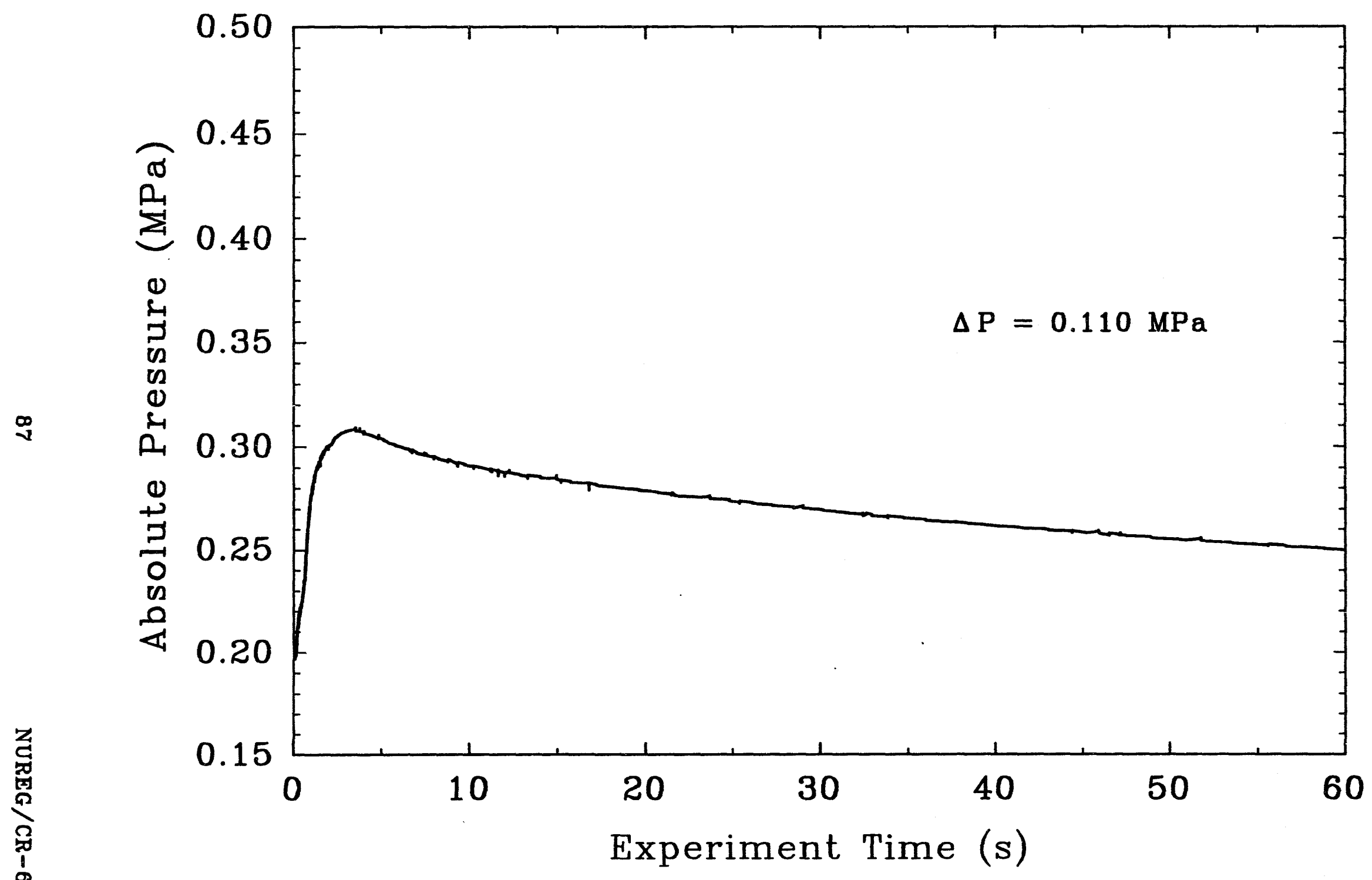

Figure 3.19 Surtsey vessel pressure versus time in the IET-1R experiment 
Z

$\infty$

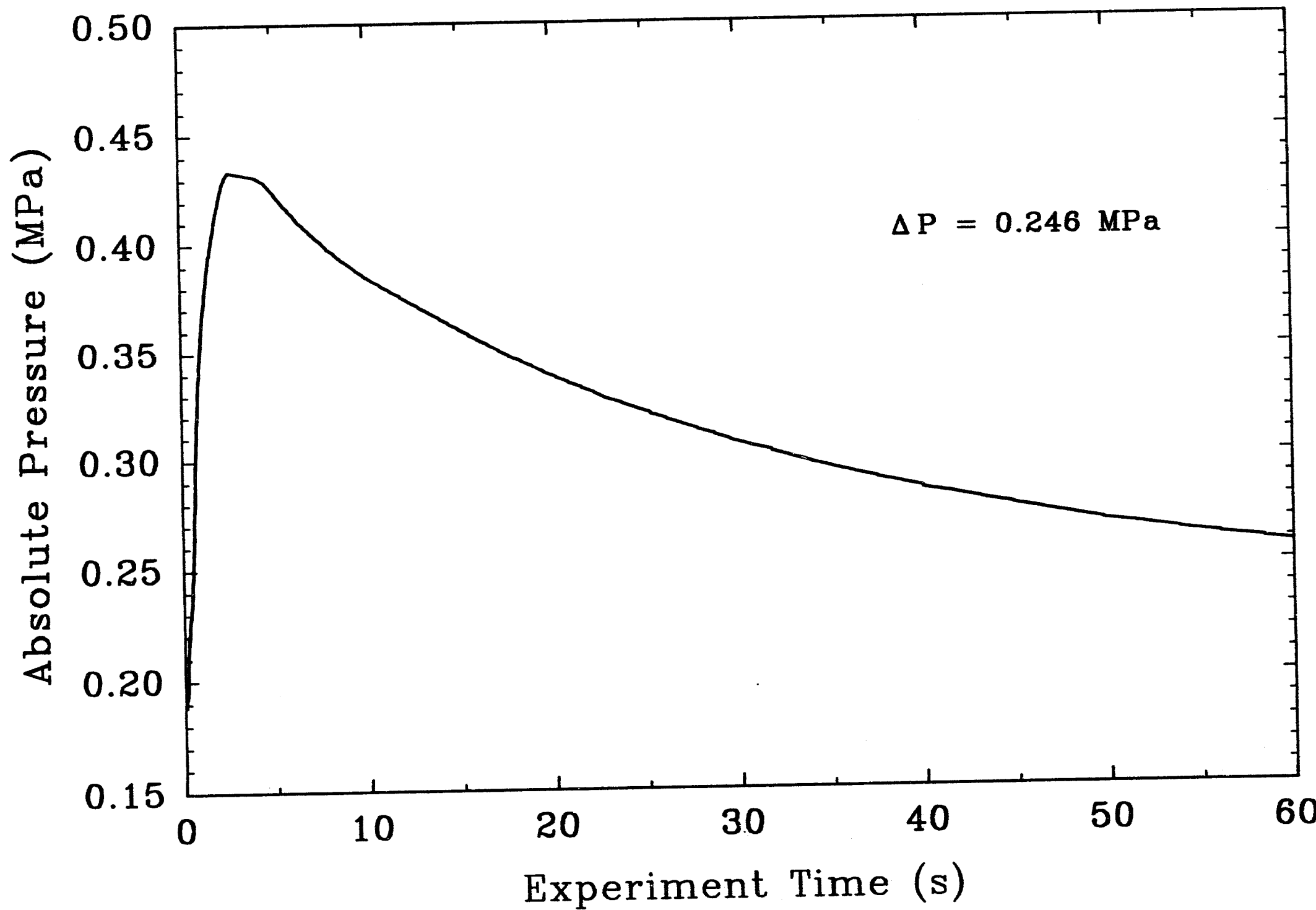

Figure 3.20 Surtsey vessel pressure versus time in the IET-3 experiment 


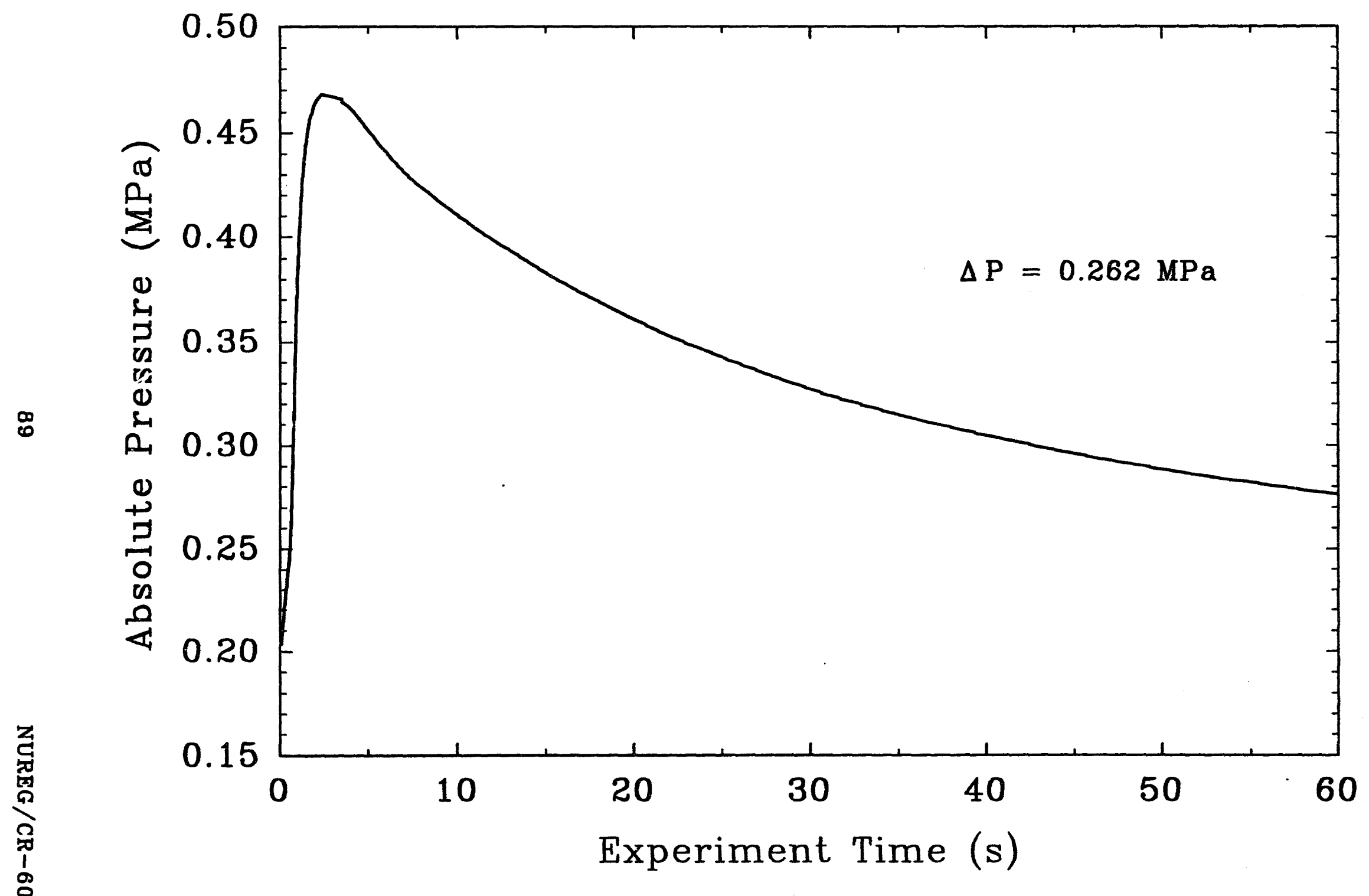

Figure 3.21 Surtsey vessel pressure versus time in the IET-4 experiment 
$z$
0
0
0
0
0
0
1
0
0
0
0
$\mathbb{1}$

ஜீ

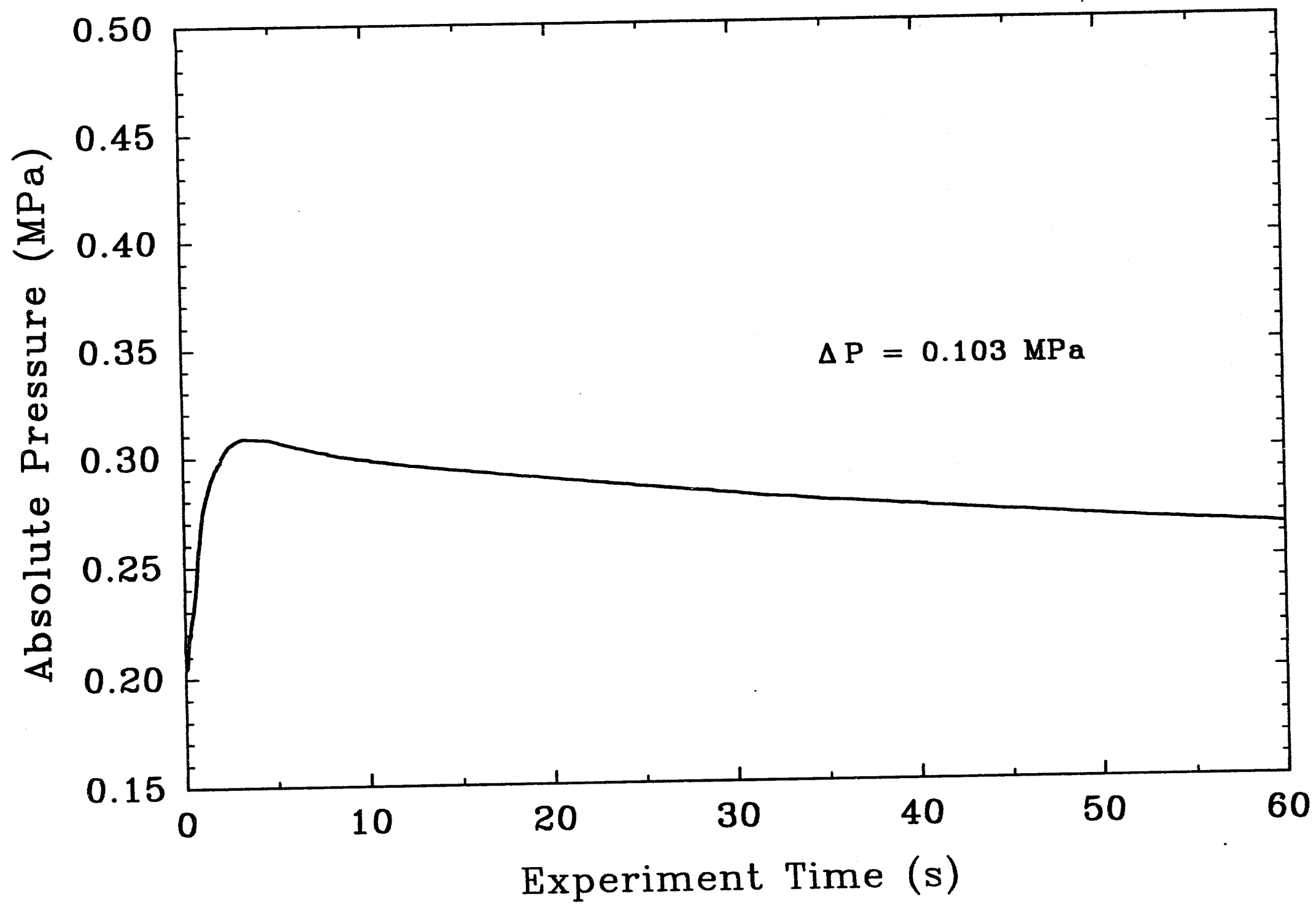

Figure 3.22 Surtsey vessel pressure versus time in the IET-5 experiment 


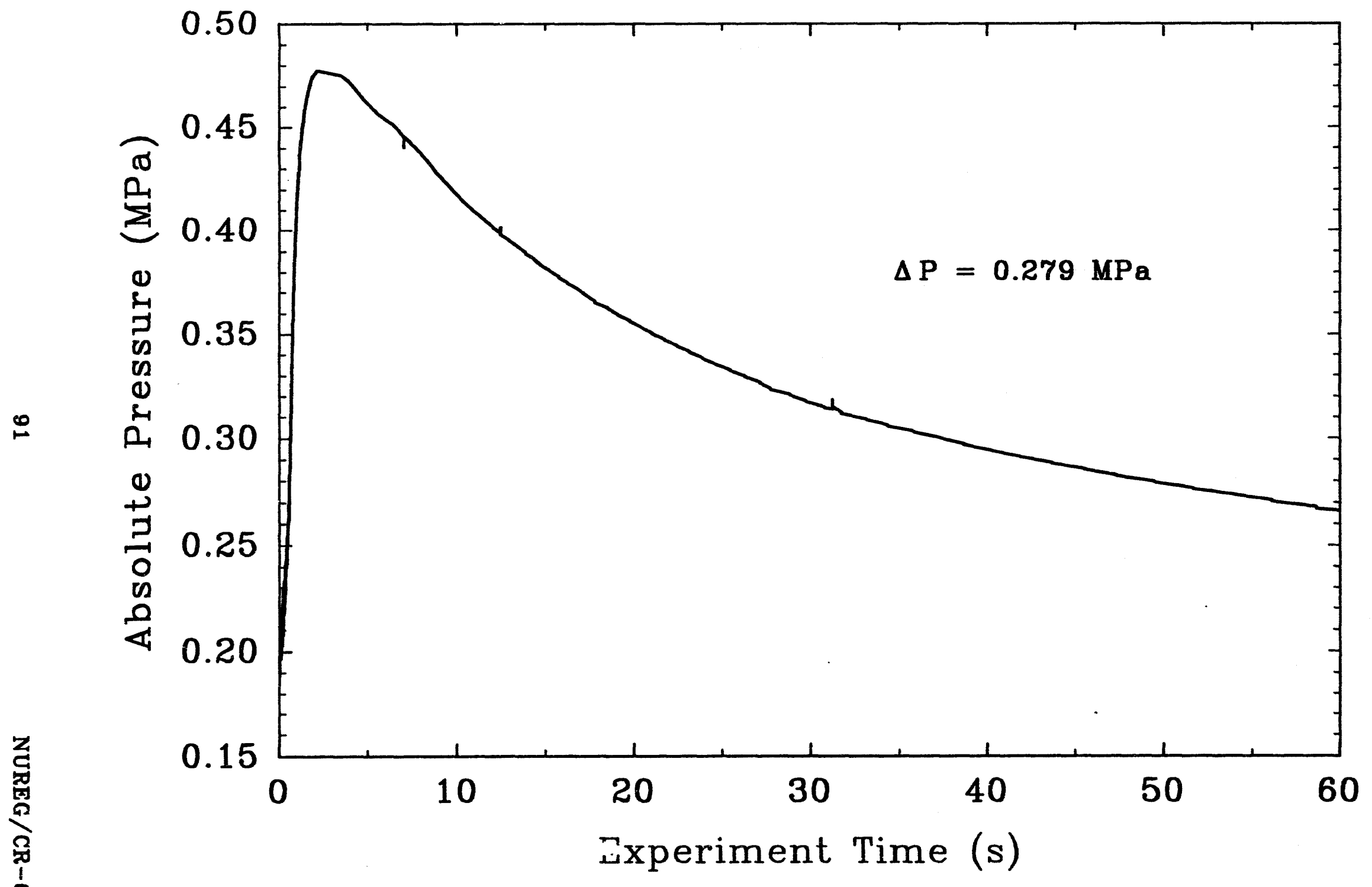

Figure 3.23 Surtsey vessel pressure versus time in the IET-6 experiment 


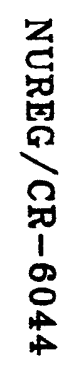

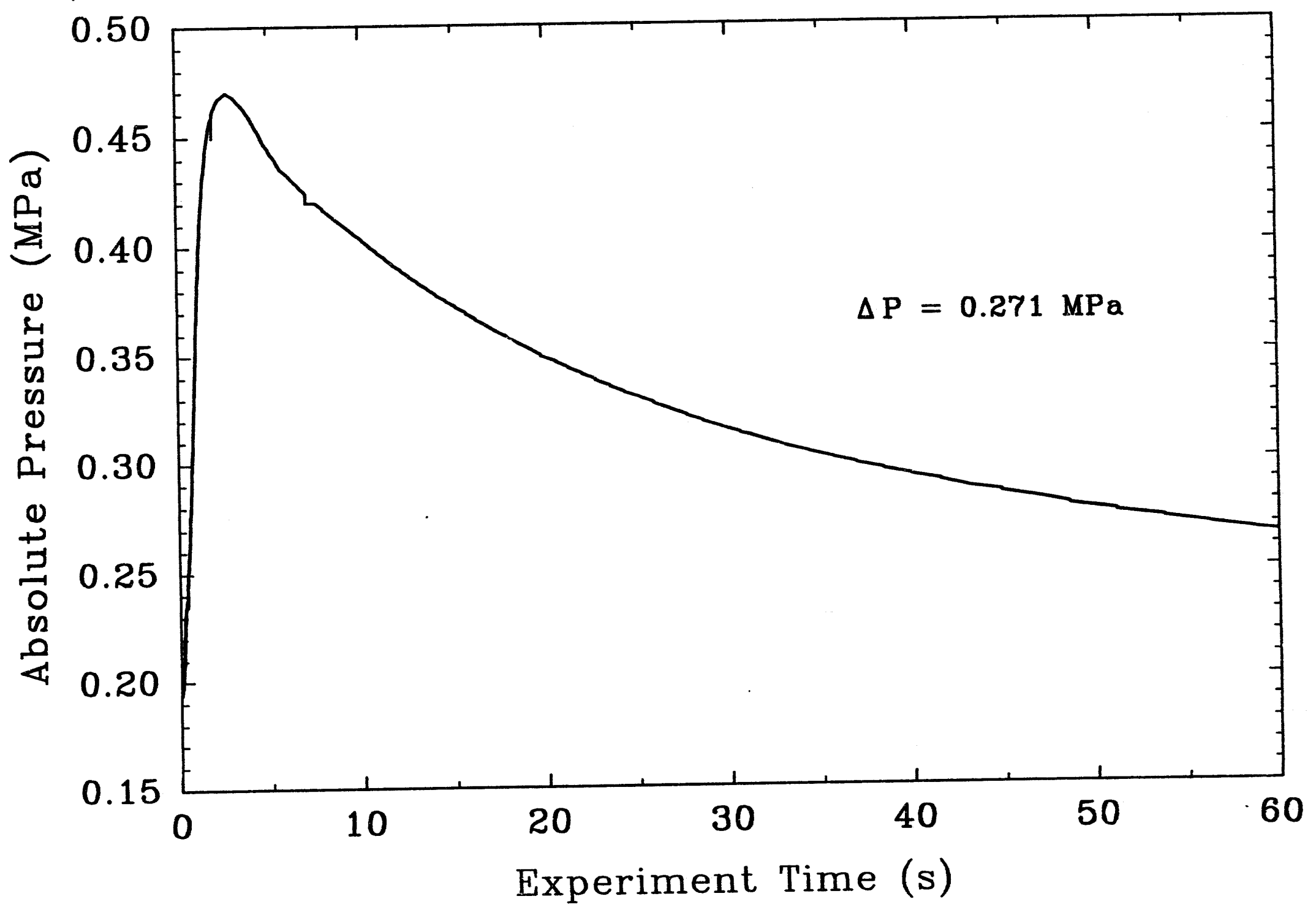

Figure 3.24 Surtsey vessel pressure versus time in the IET-7 experiment 


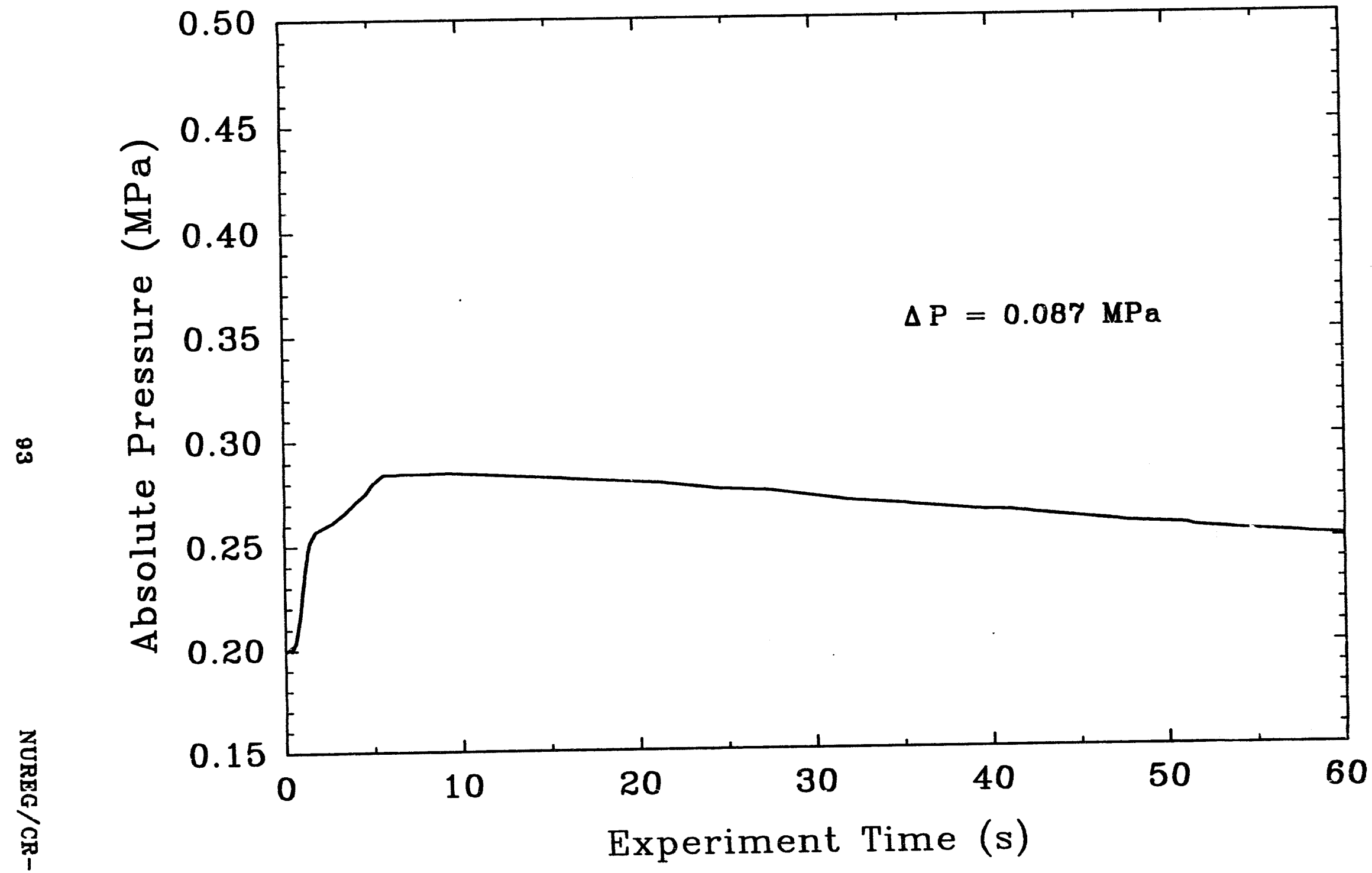

Figure 3.25 Surtsey vessel pressure versus time in the IET-BA experiment 
忌

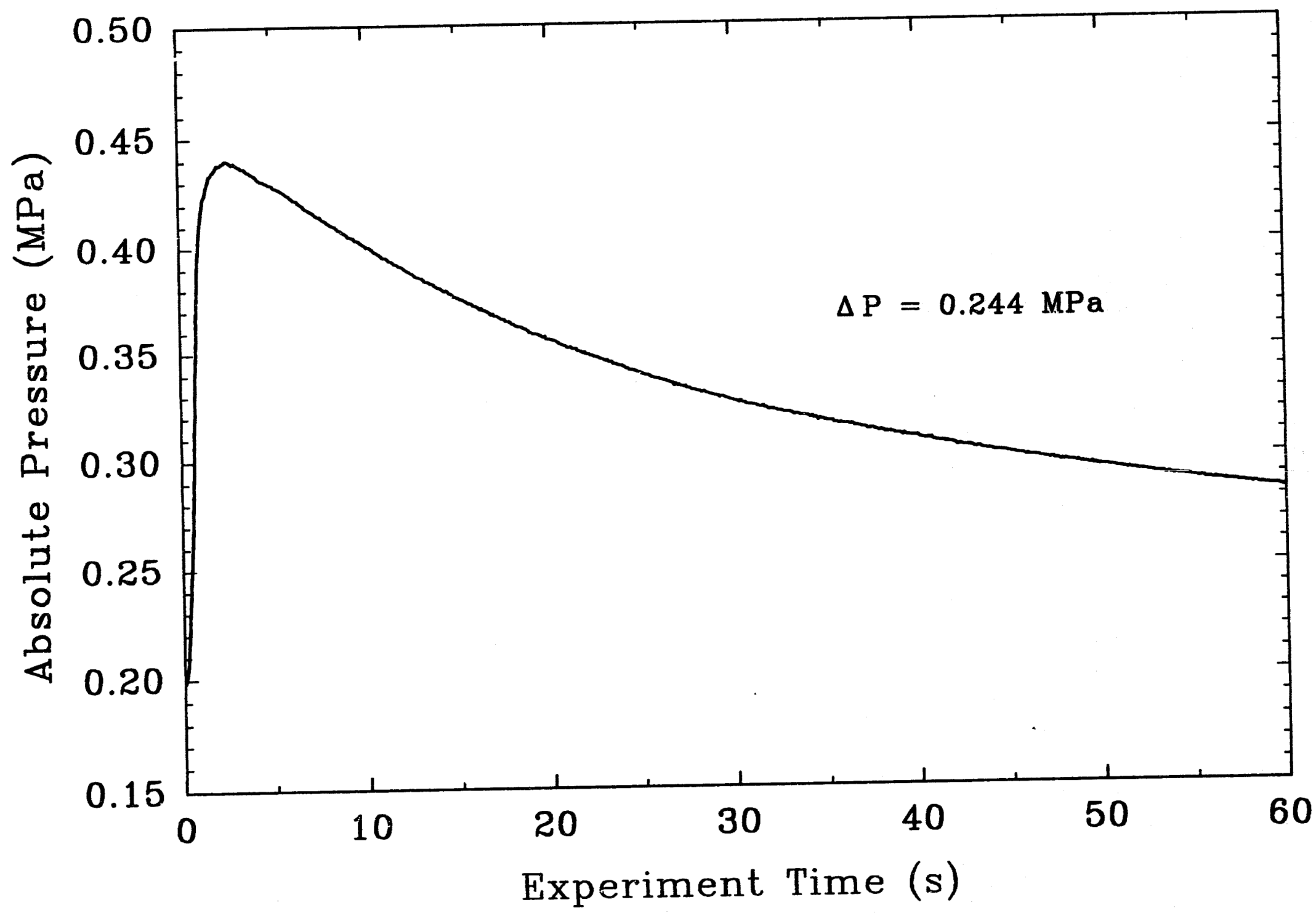

Figure 3.26 Surtsey vessel pressure versus time in the IET-8B experiment 


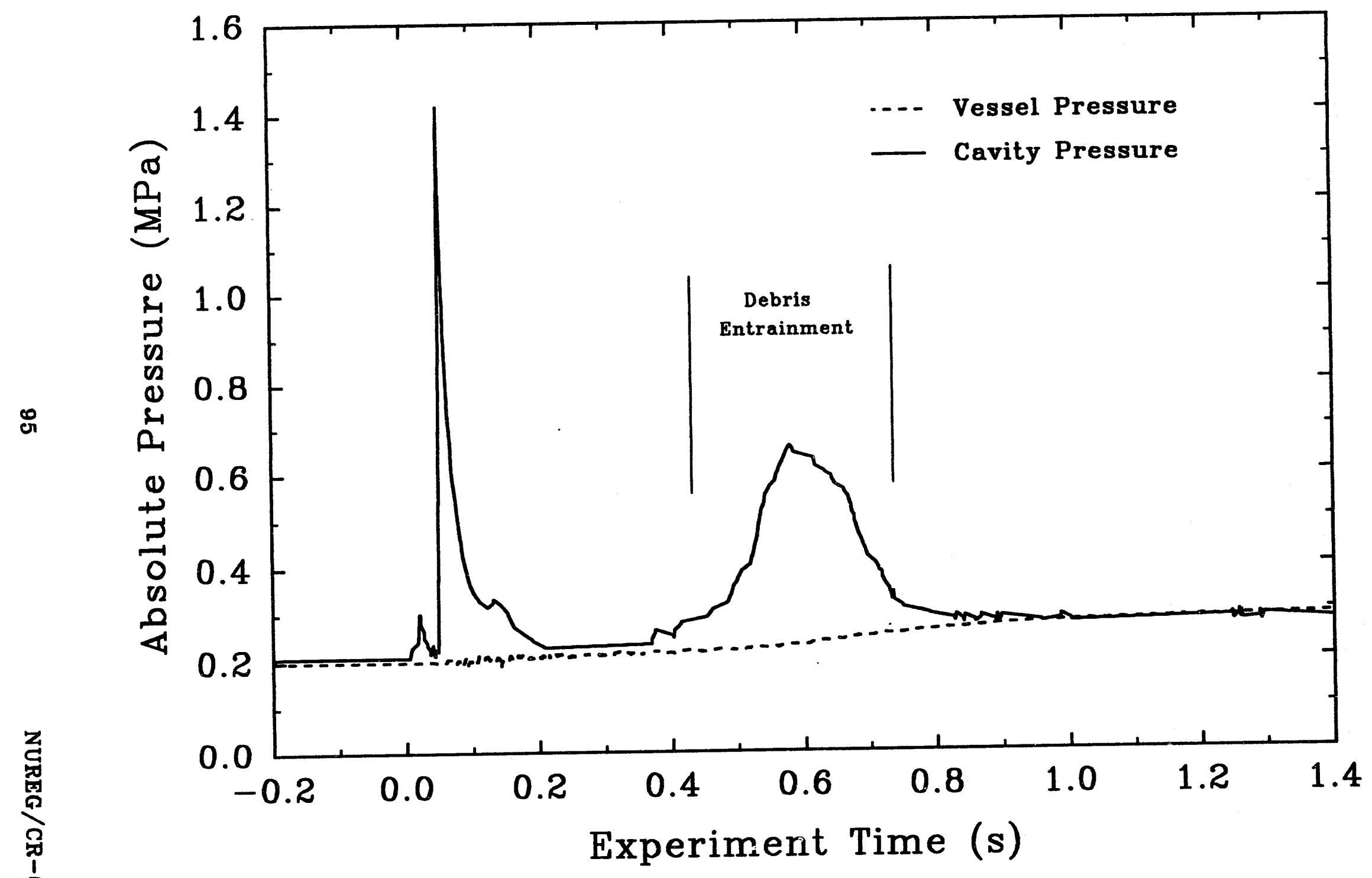

Figure 3.27 Cavity pressure and Surtsey vessel pressure versus time in the IET-1 experiment 


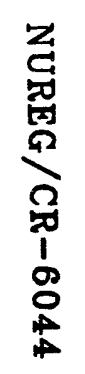

ஃ

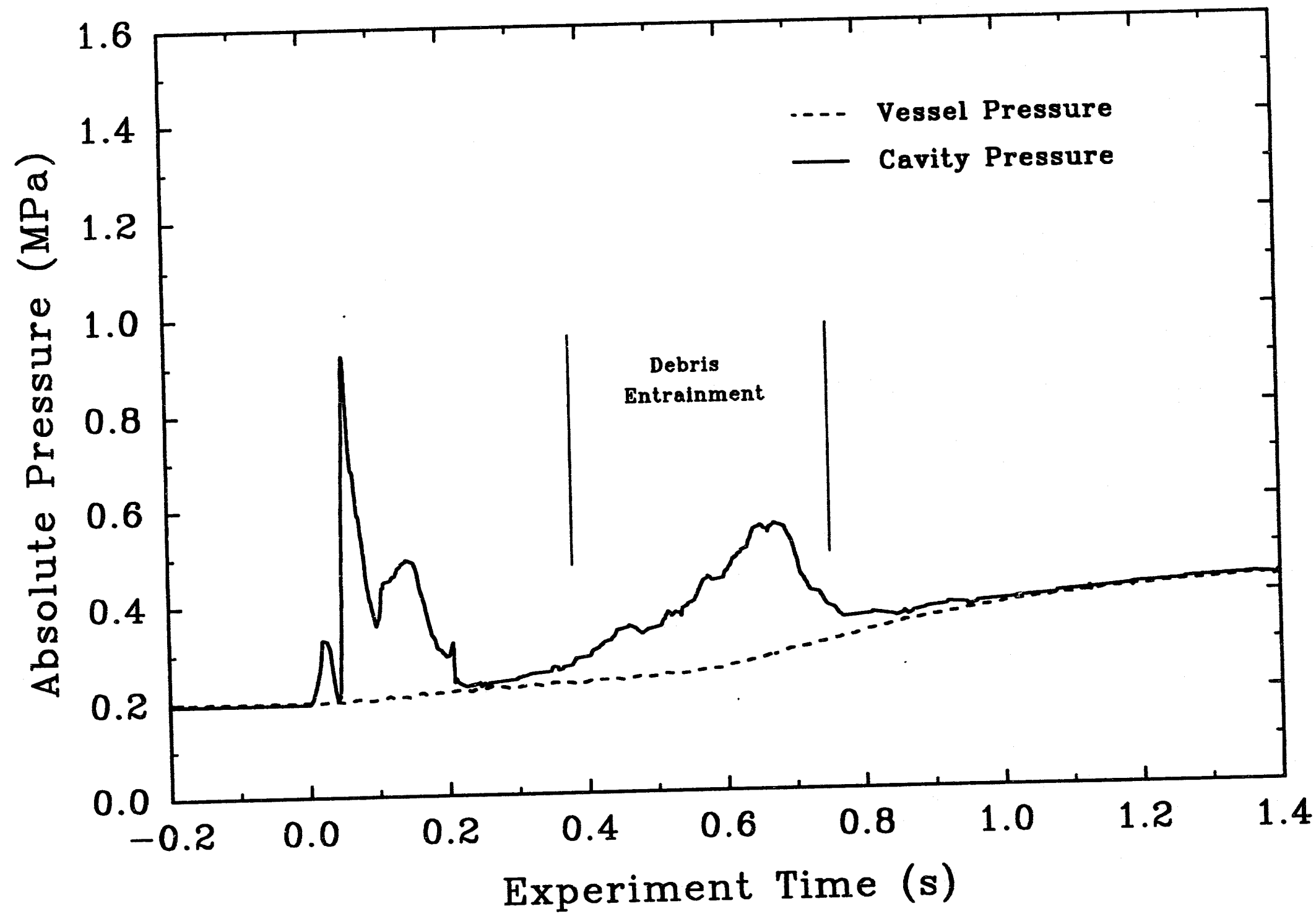

Figure 3.28 Cavity pressure and Surtsey vessel pressure versus time in the IET-1R experiment 


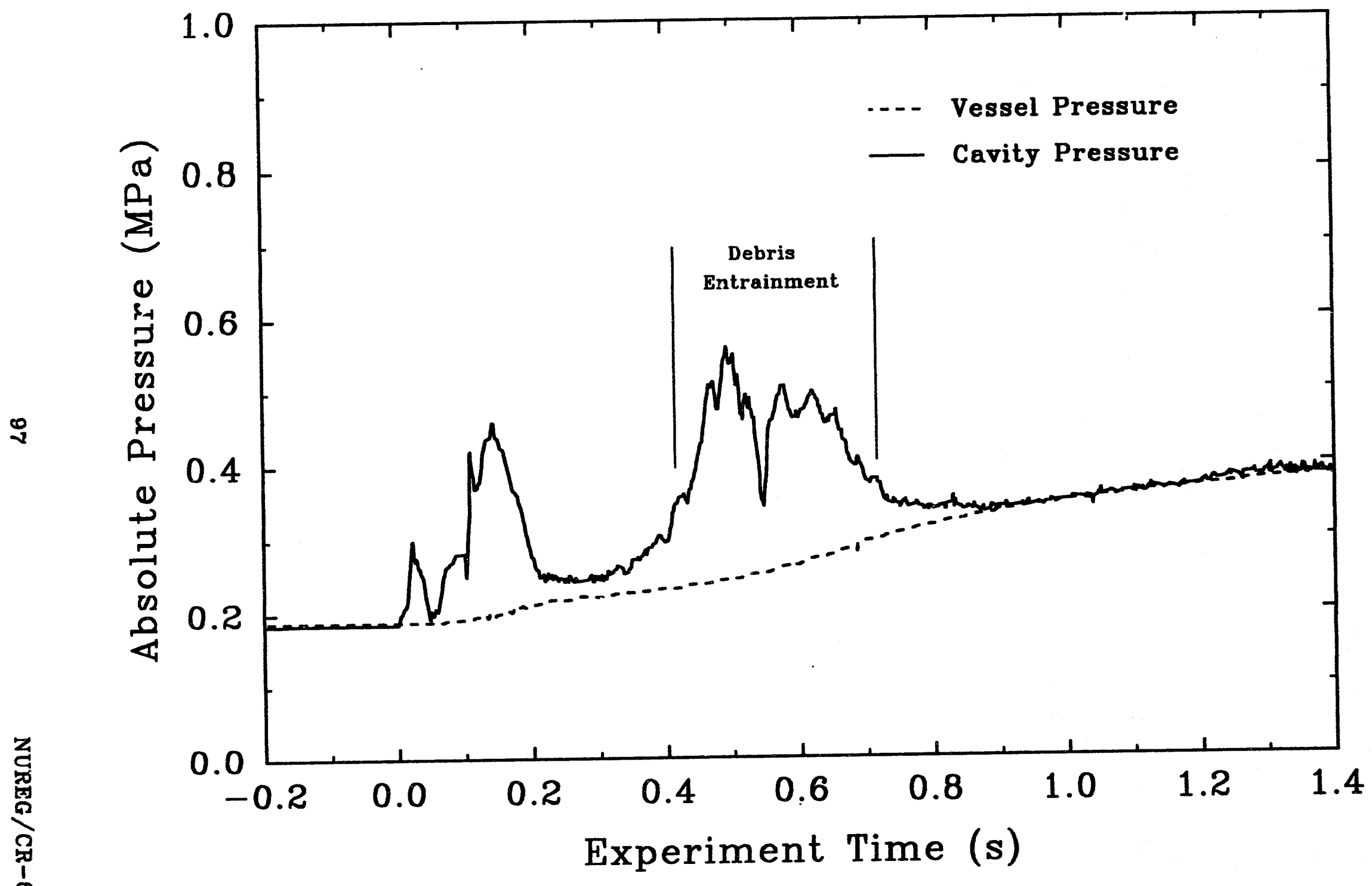

Figure 3.29 Cavity pressure and Surtsey vessel pressure versus time in the IET-3 experiment 


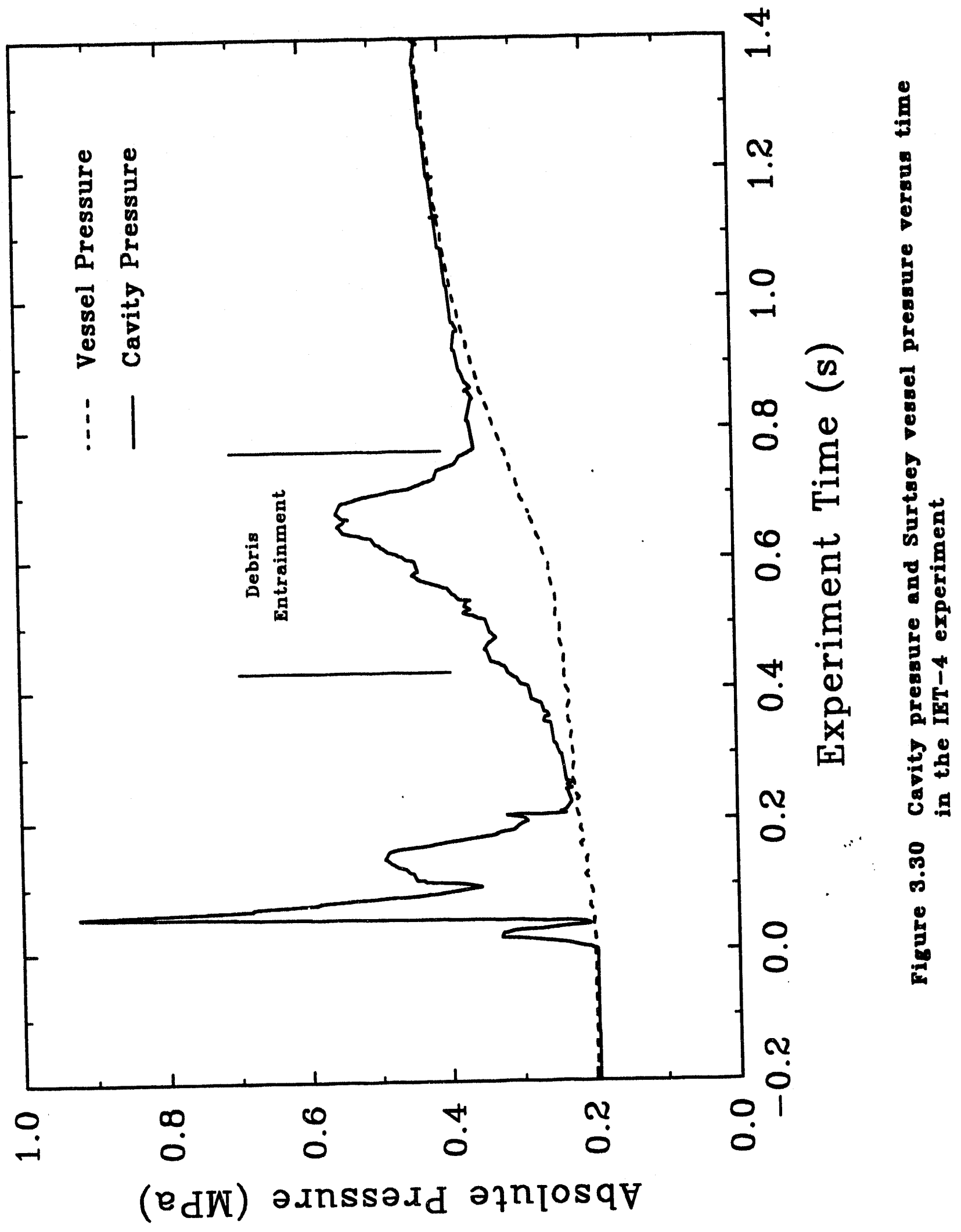




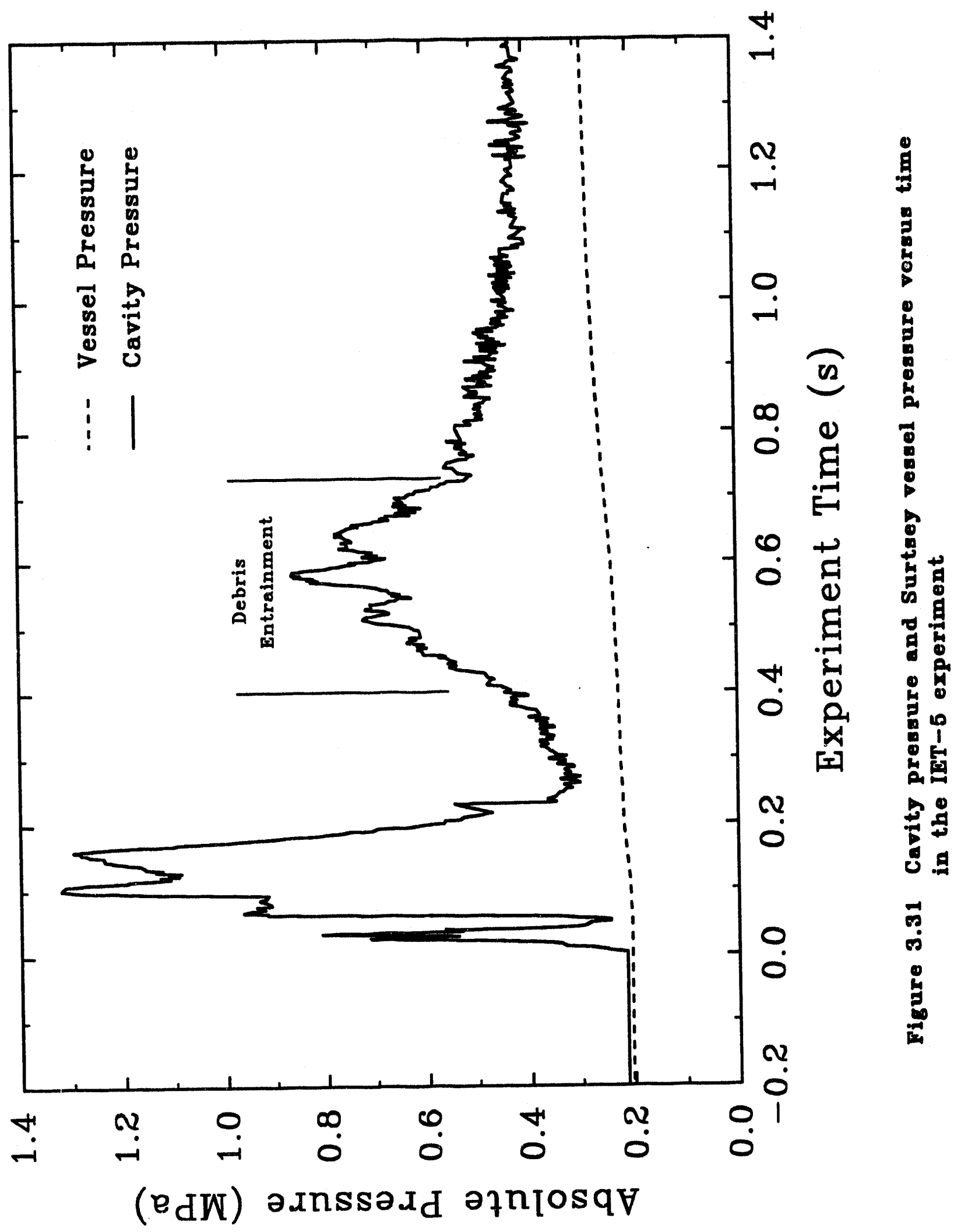


忌

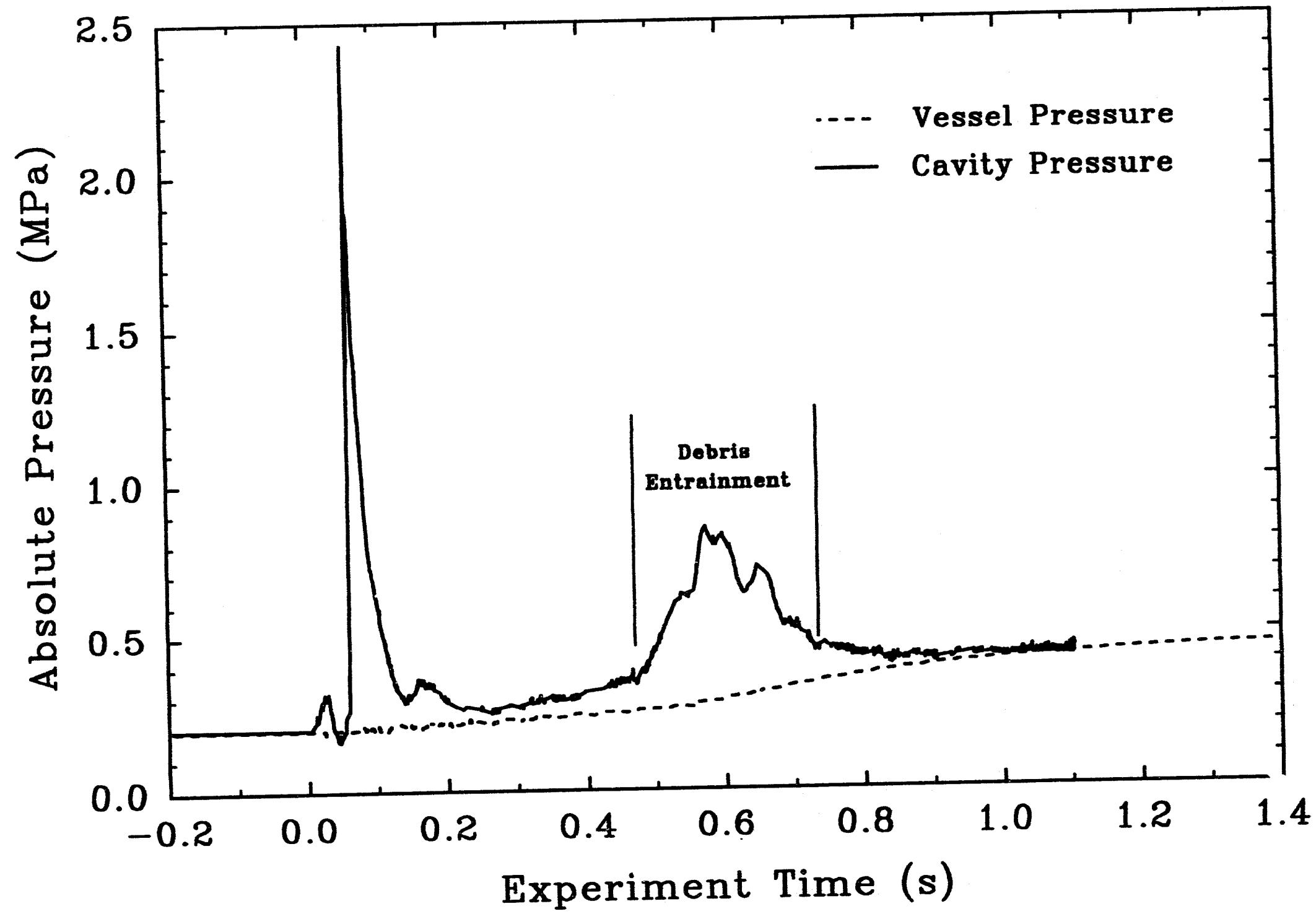

Figure 3.32 Cavity pressure and Surtsey vessel pressure versus time in the IET-6 experiment 


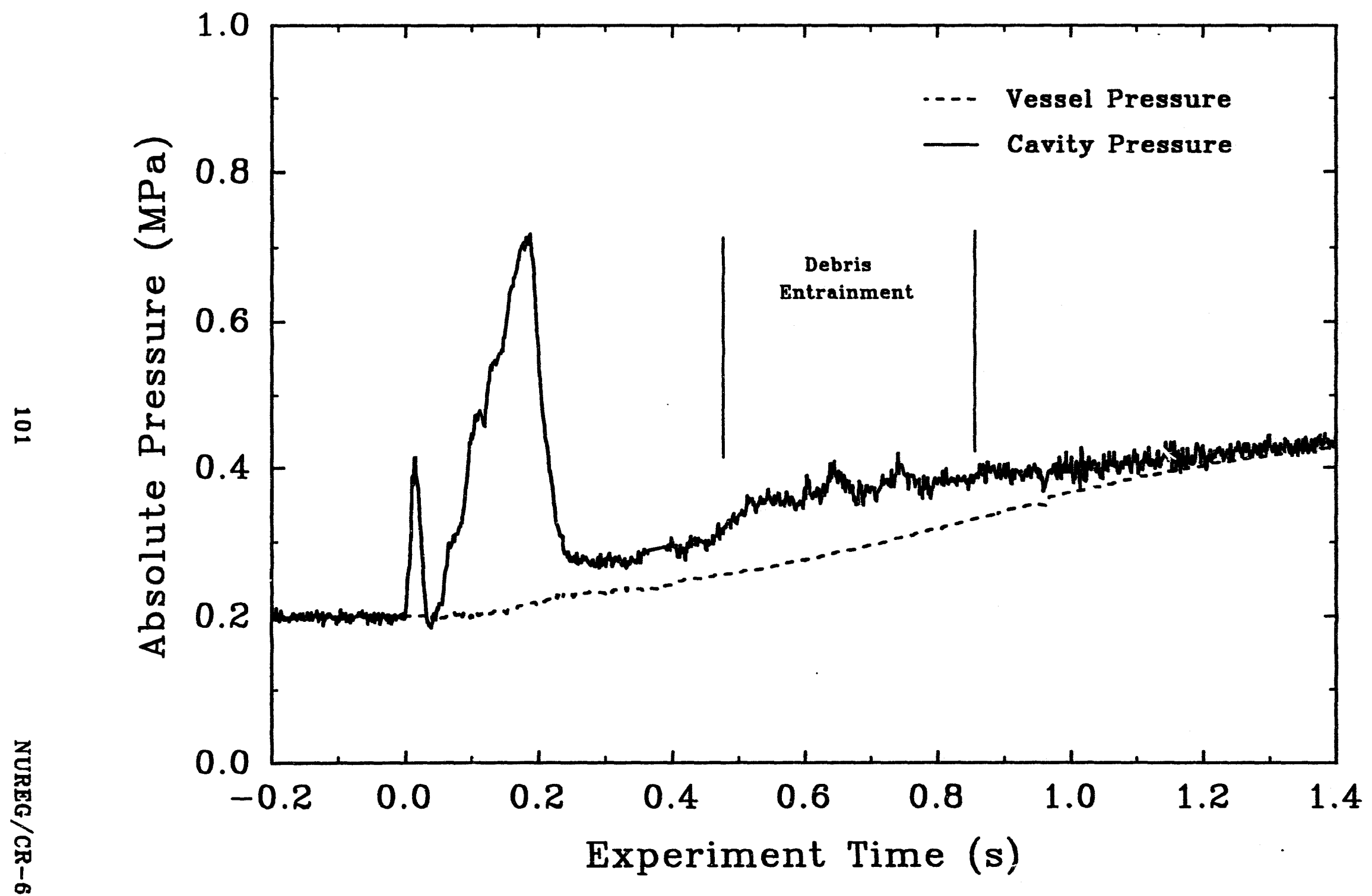

Figure 3.33 Cavity pressure and Surtsey vessel pressure versus time in the IET -7 experiment 


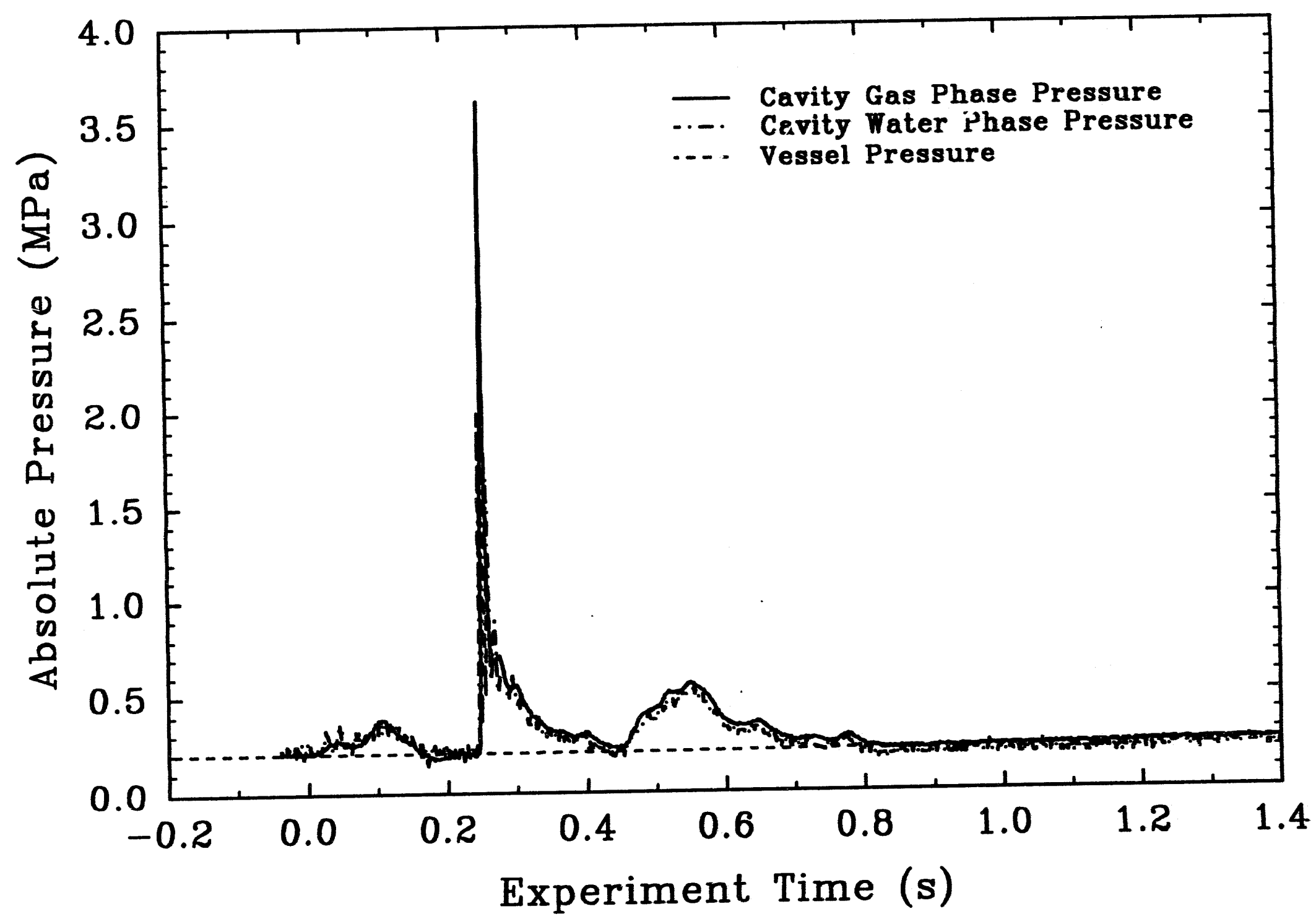

Figure 3.34 Cavity pressure and Surtsey vessel pressure versus time in the IET $-8 \mathrm{~A}$ experiment 


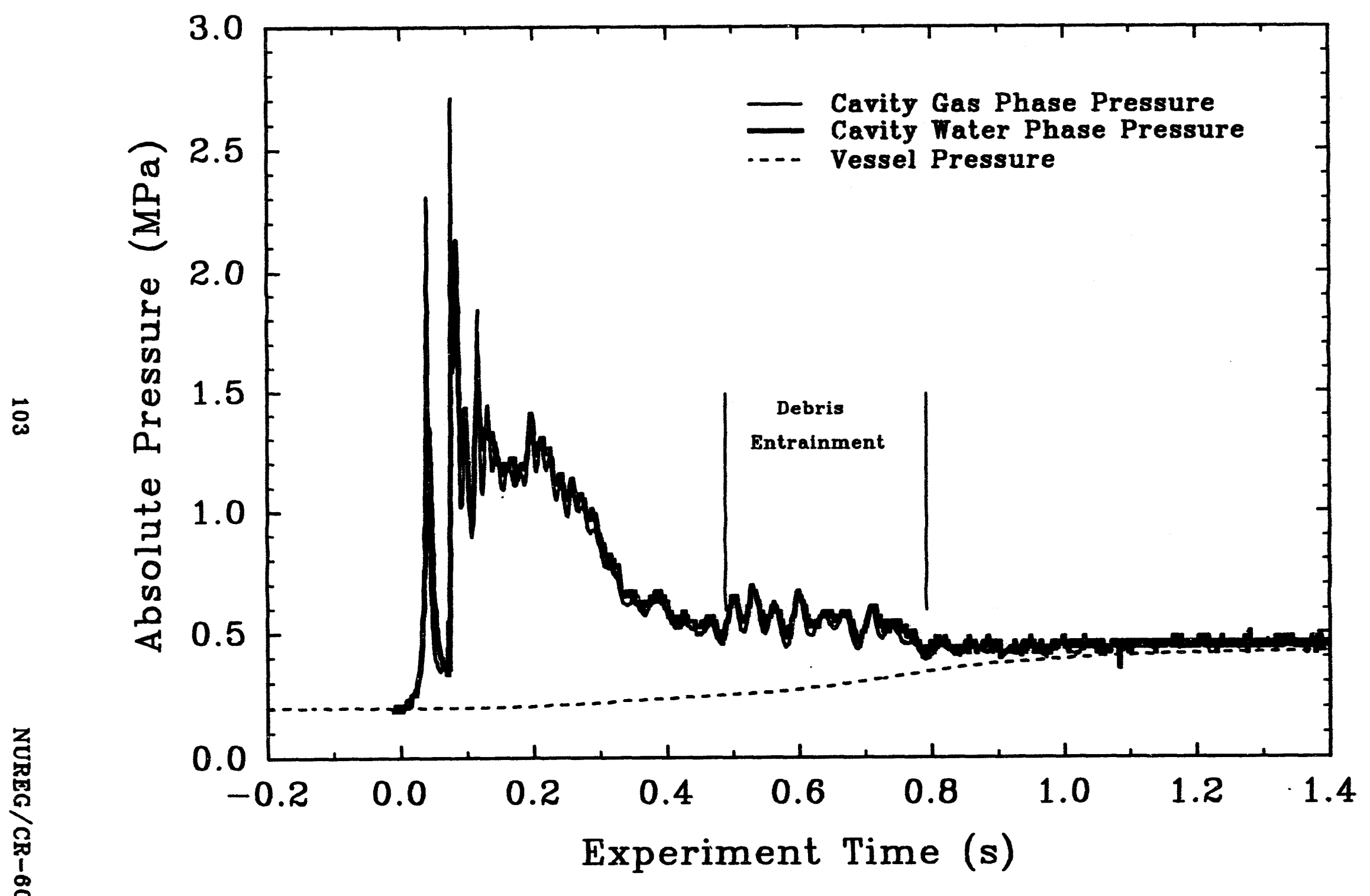

Figure 3.35 Cavity pressure and Surtsey vessel pressure versus time in the IET-BB experiment 
忌

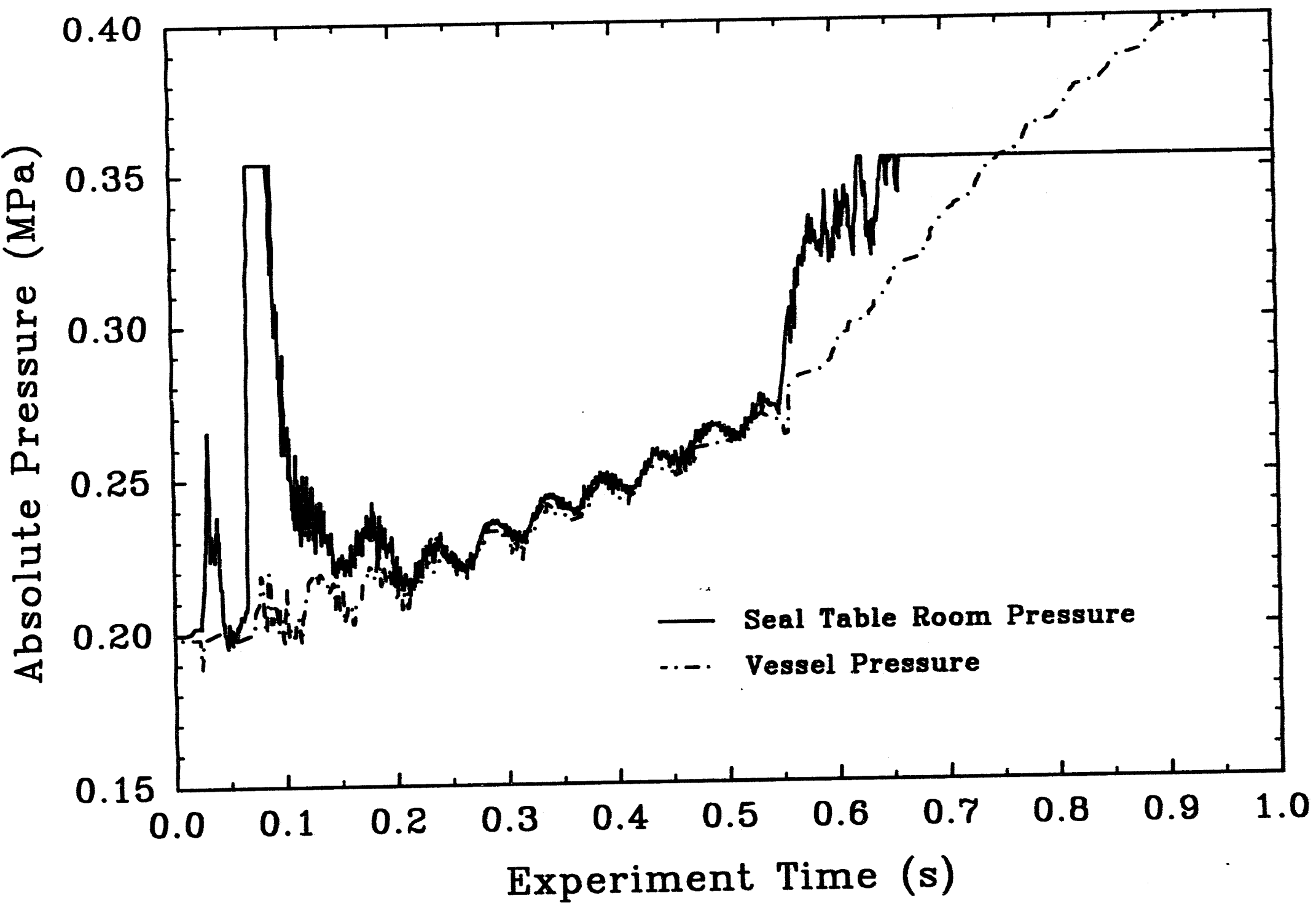

Figure 3.36 Seal table room presaure and Surtsey vessel pressure versus time in the IET-6 experiment 


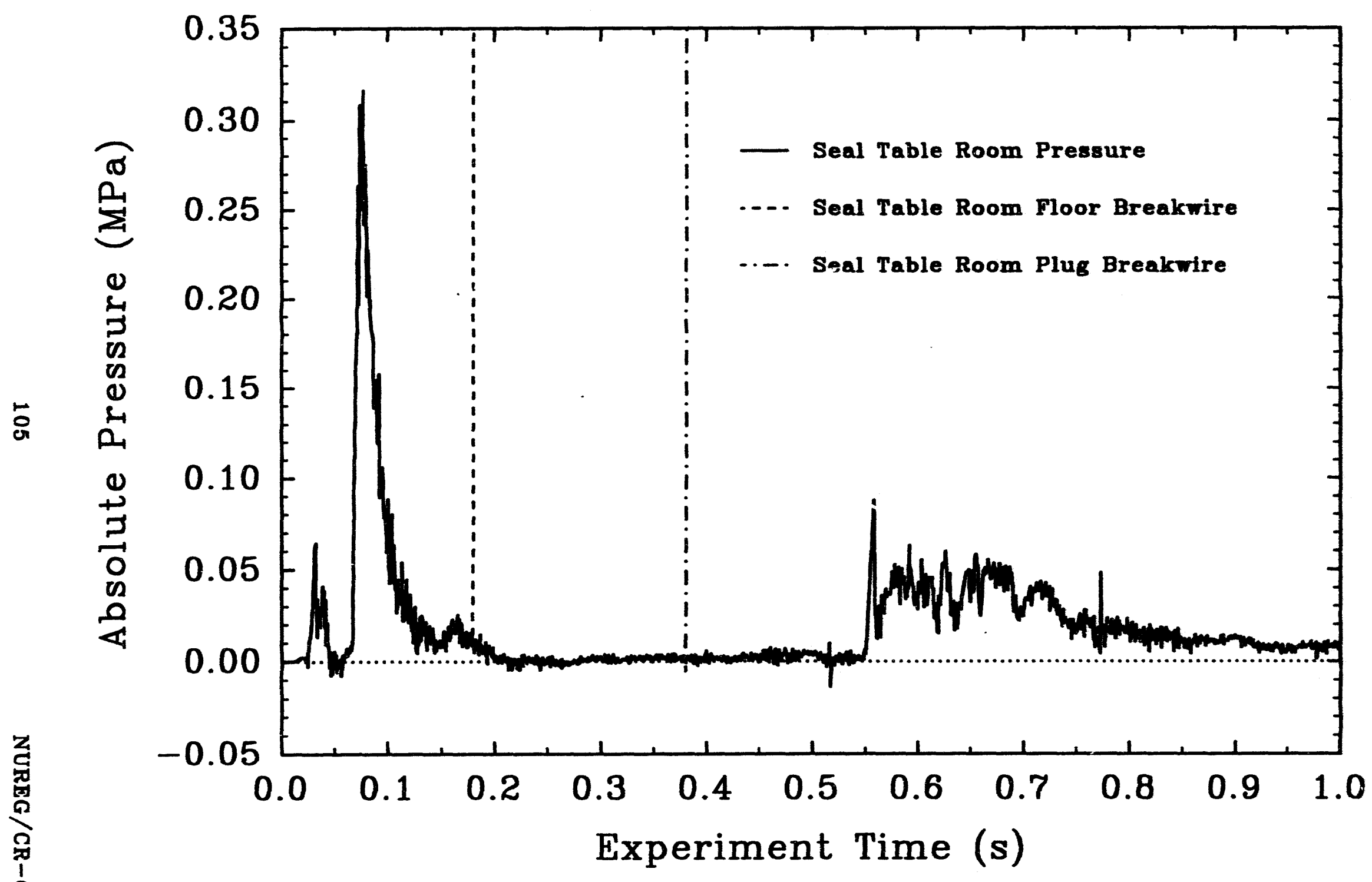

Figure 3.37 Seal table room differential pressure and debria ejection timing in the IET-6 experiment 


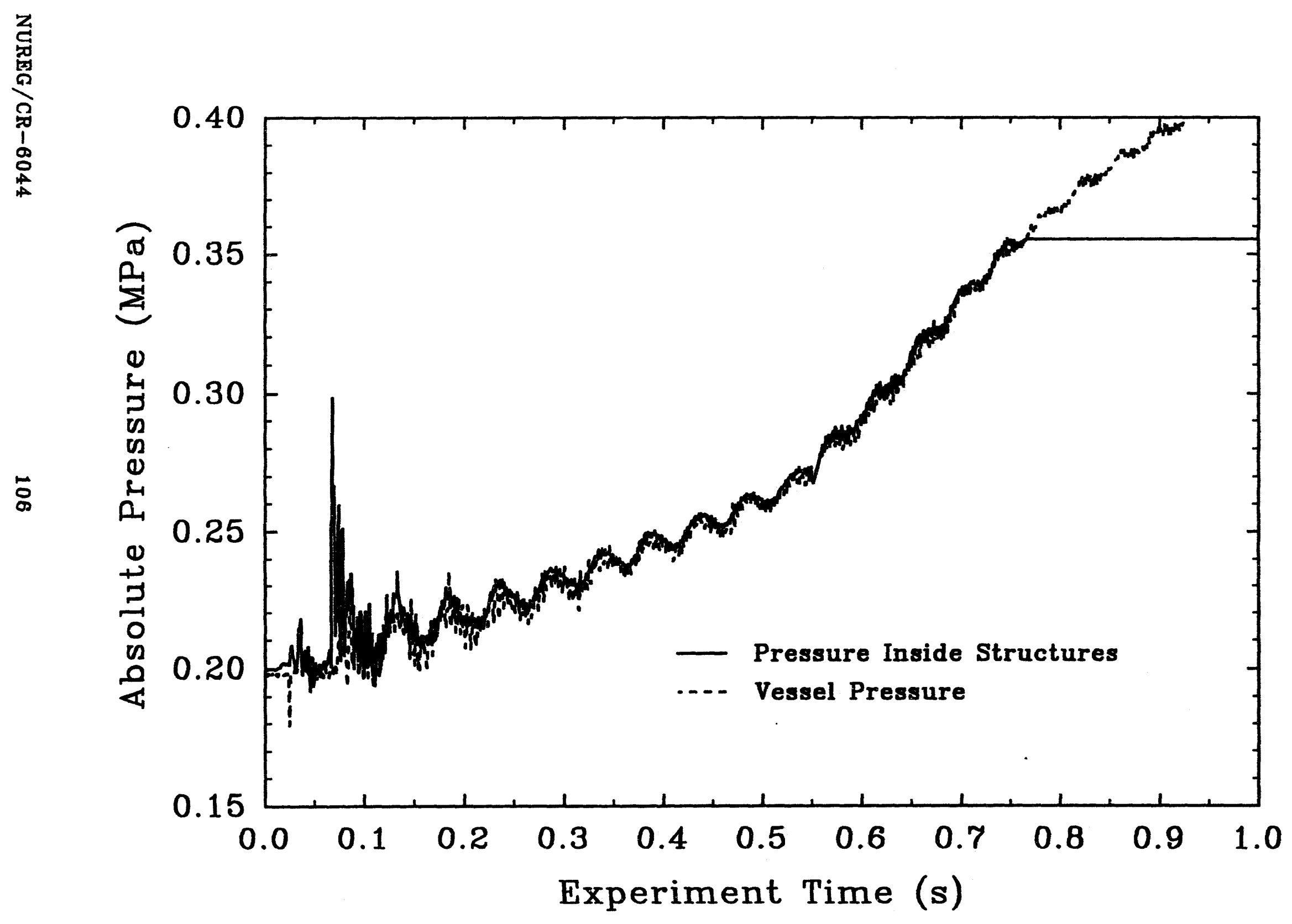

Figure 3.38 Subcompartment absolute presaure compared to Surtsey vessel presaure in the IET-6 experiment 


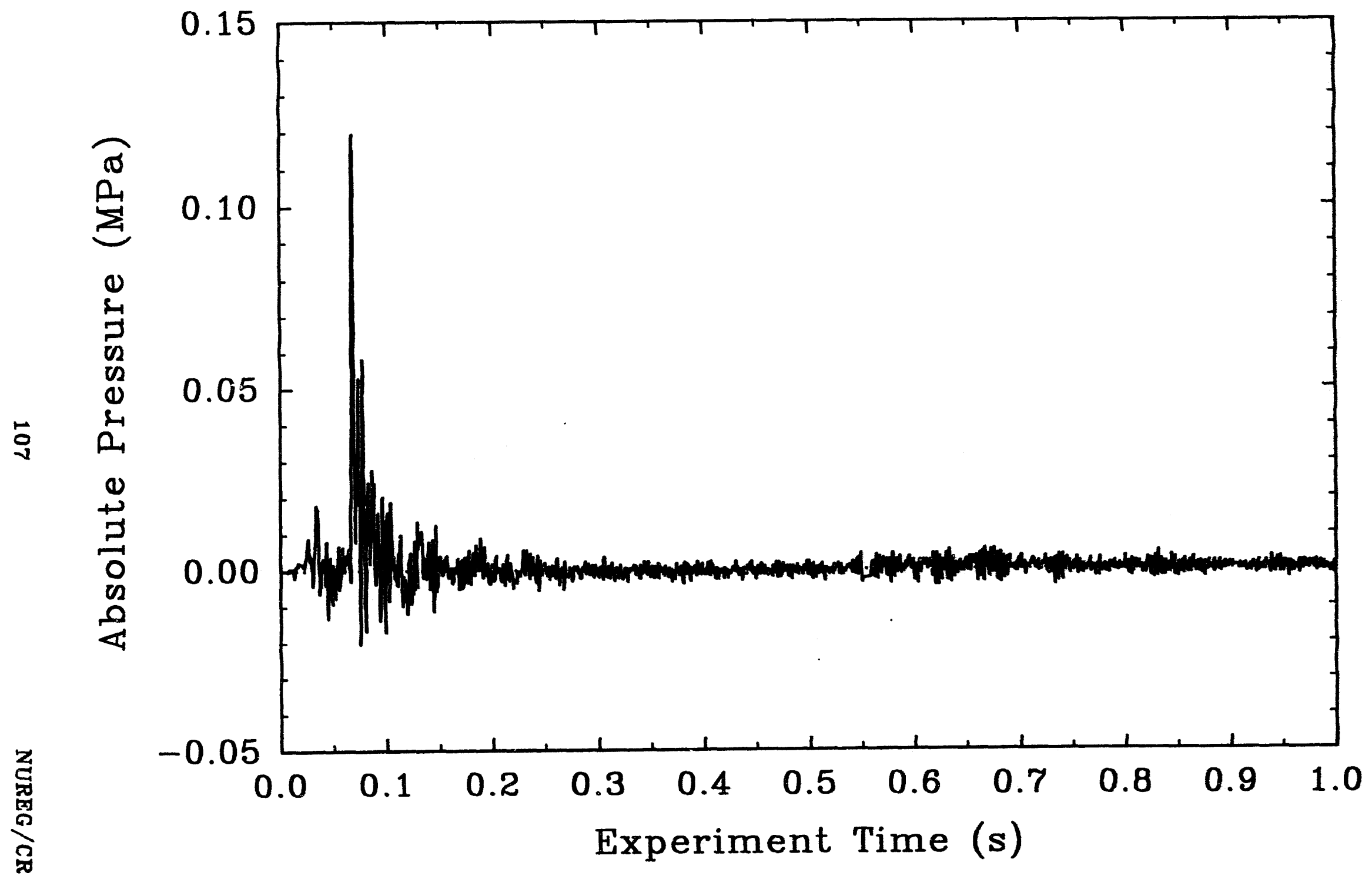

Figure 3.39 Subcompartment differential pressure in the IET-6 experiment 


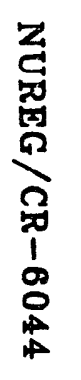

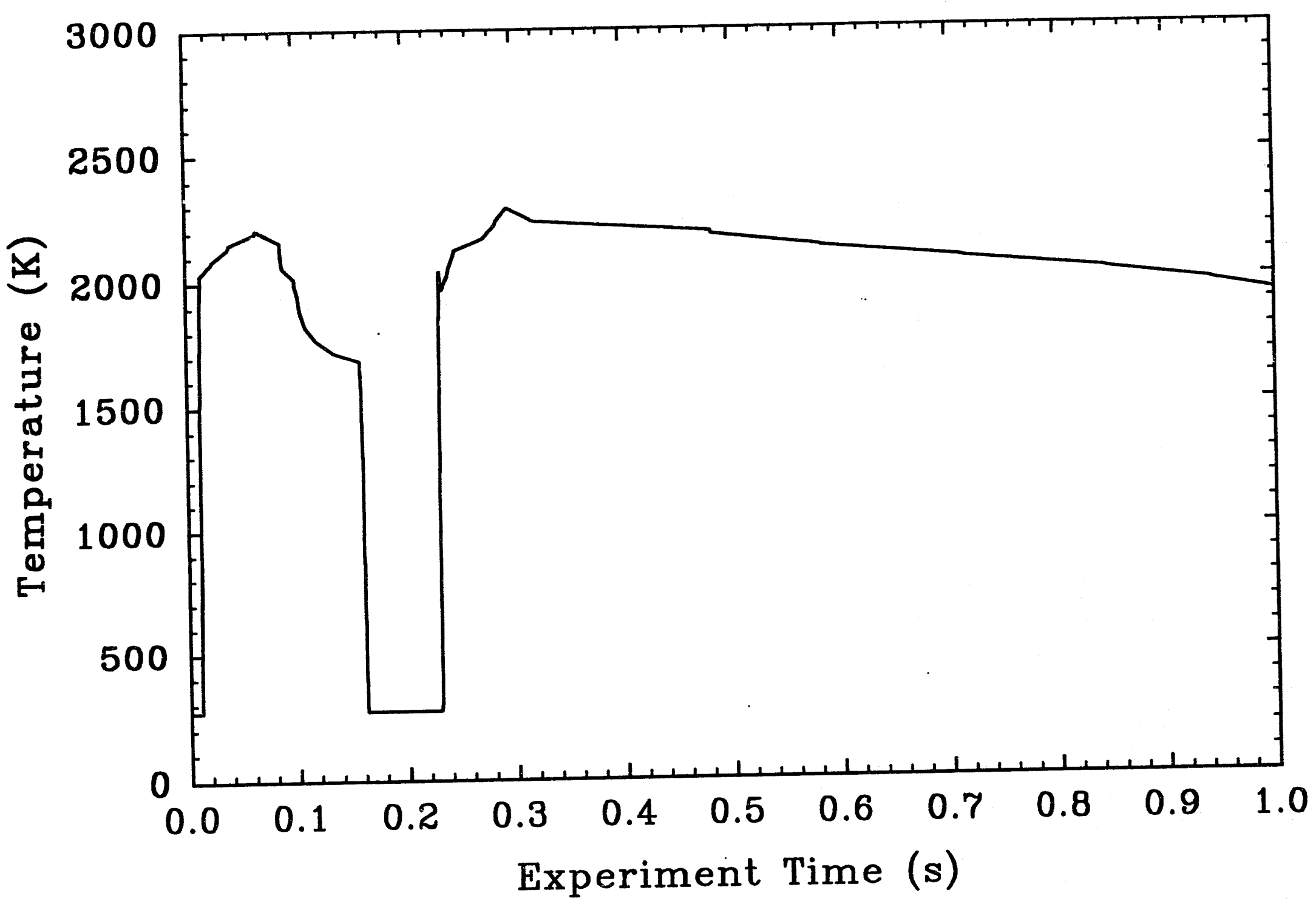

Figure 3.40 Thermite temperature measured from the west side of the melt generator exit with the two-color pjrometer in the IET-2A experiment 


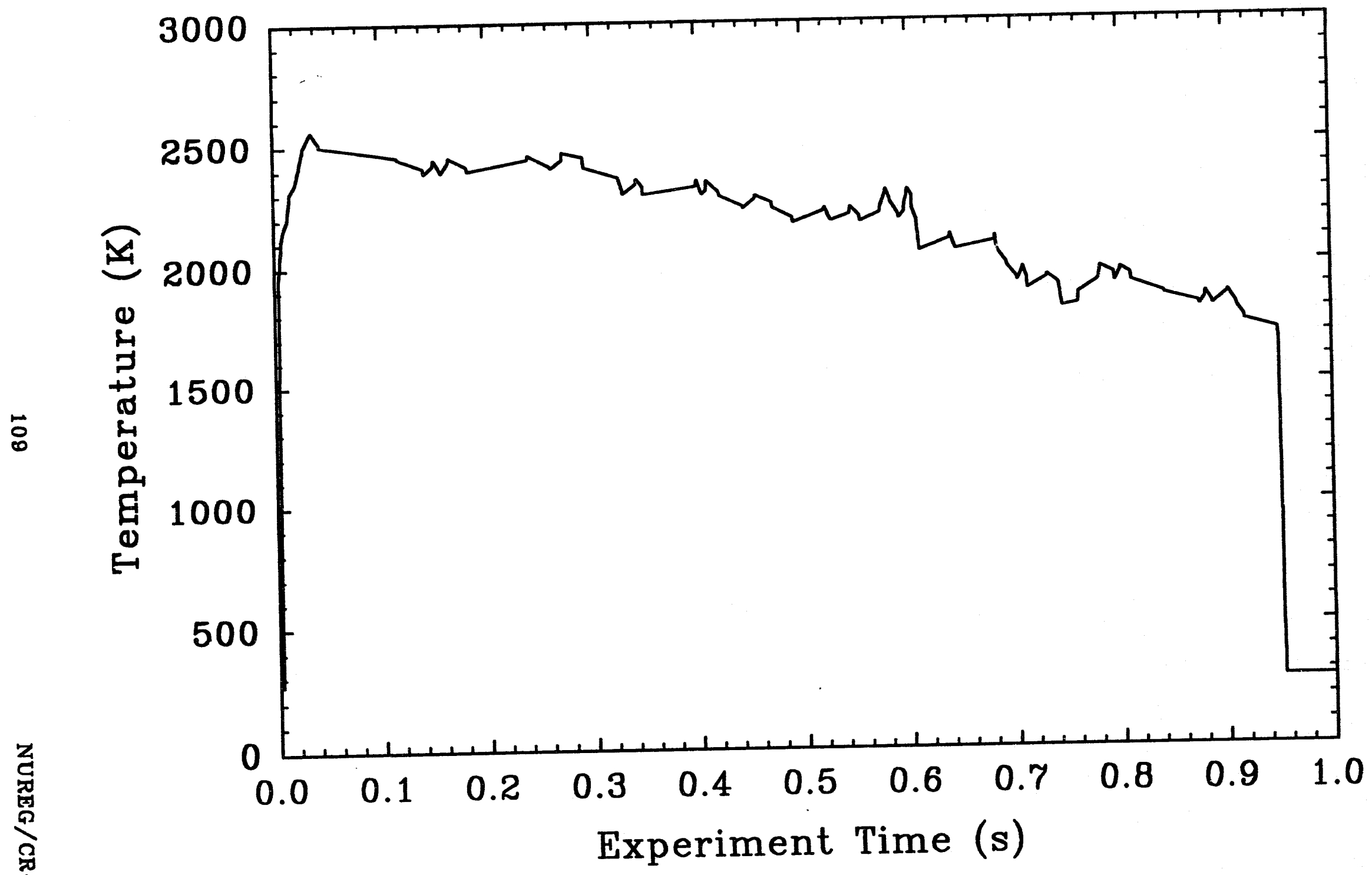

Figure 3.41 Thermite temperature measured from the west side of the melt generator exit with the two-color pyrometer in the IET-2B experiment 
Z⿱

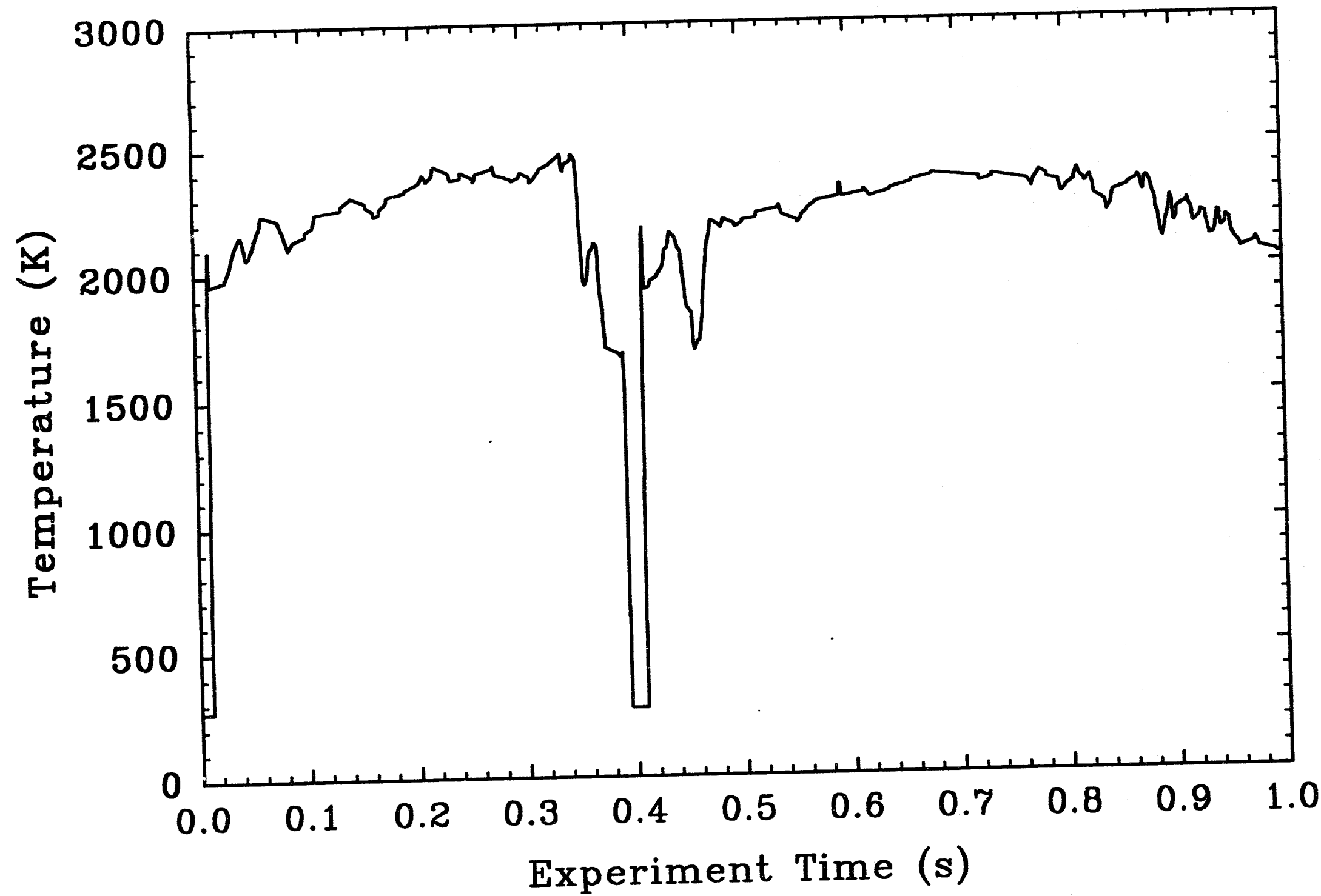

Figure 3.42 Thermite temperature measured from the west side of the m
exit with the two-color pyrometer in the IET-2C experiment 


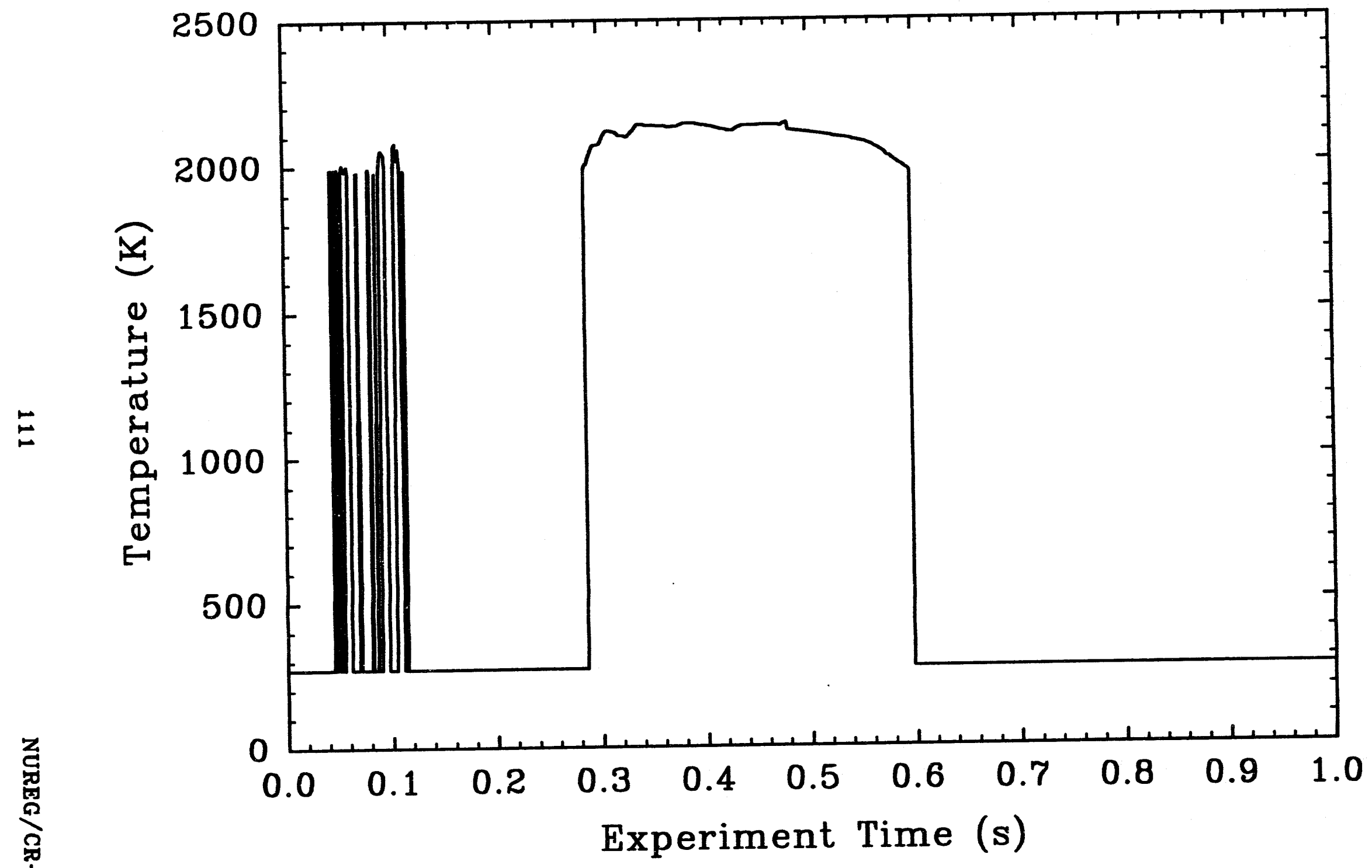

Figure 3.43 Thermite temperature measured from the east side of the melt generator exit with a type $11 \times 30$ optical pyrometer for the IET-2A experiment 


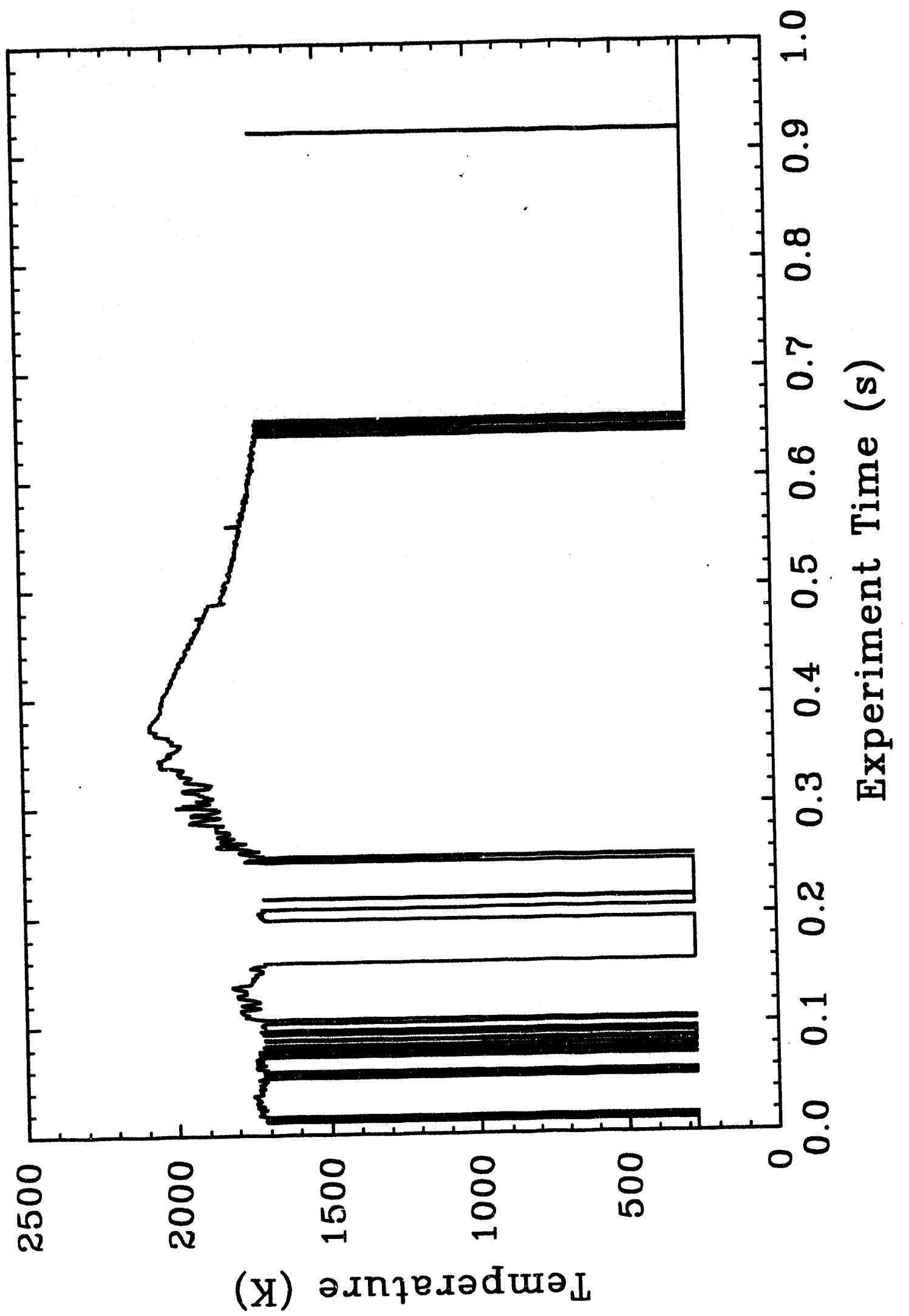




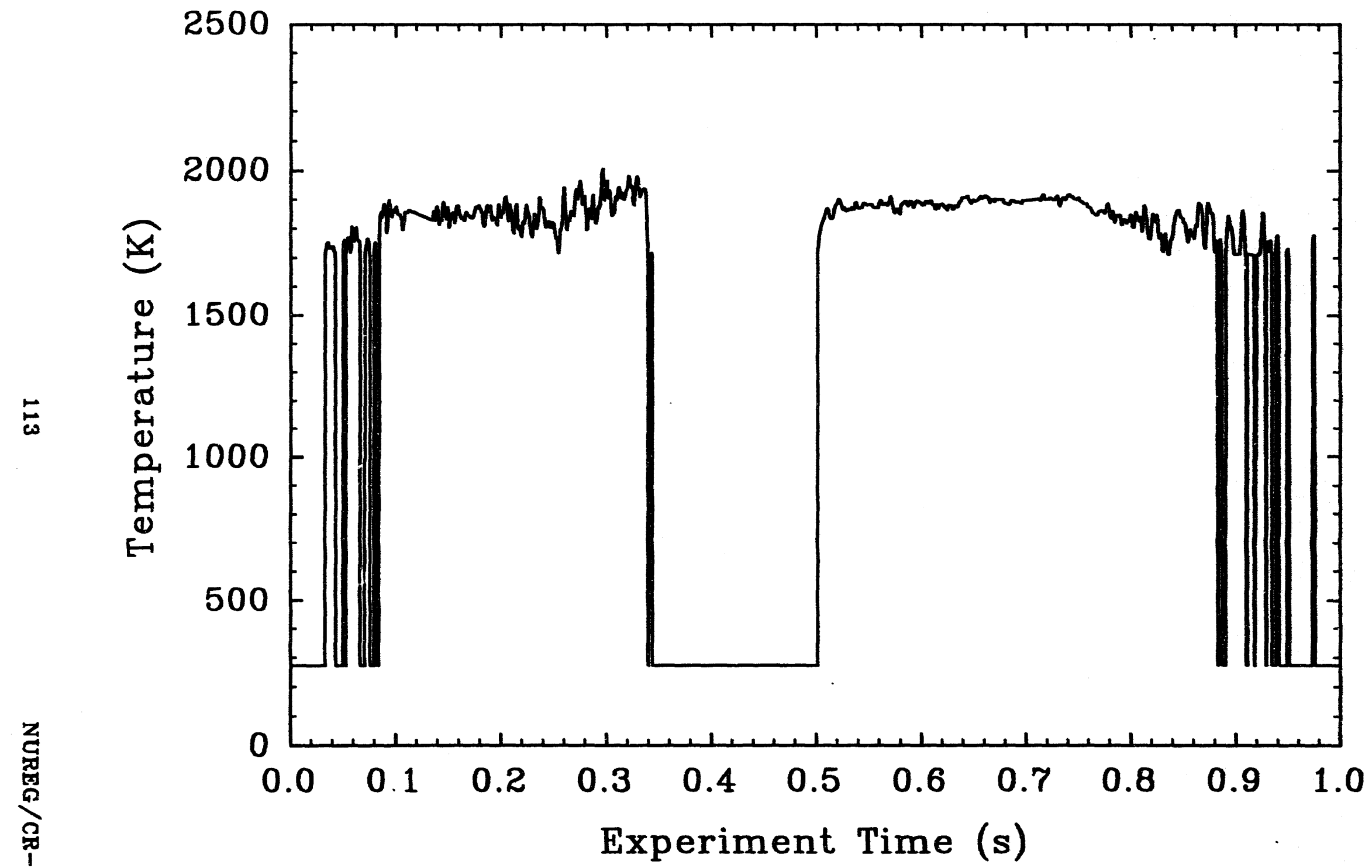

Figure 3.45 Thermite temperature measured from the east side of the melt generator exit with a type $11 \times 30$ optical pyrometer in the IET-2C experiment 
忌

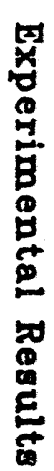

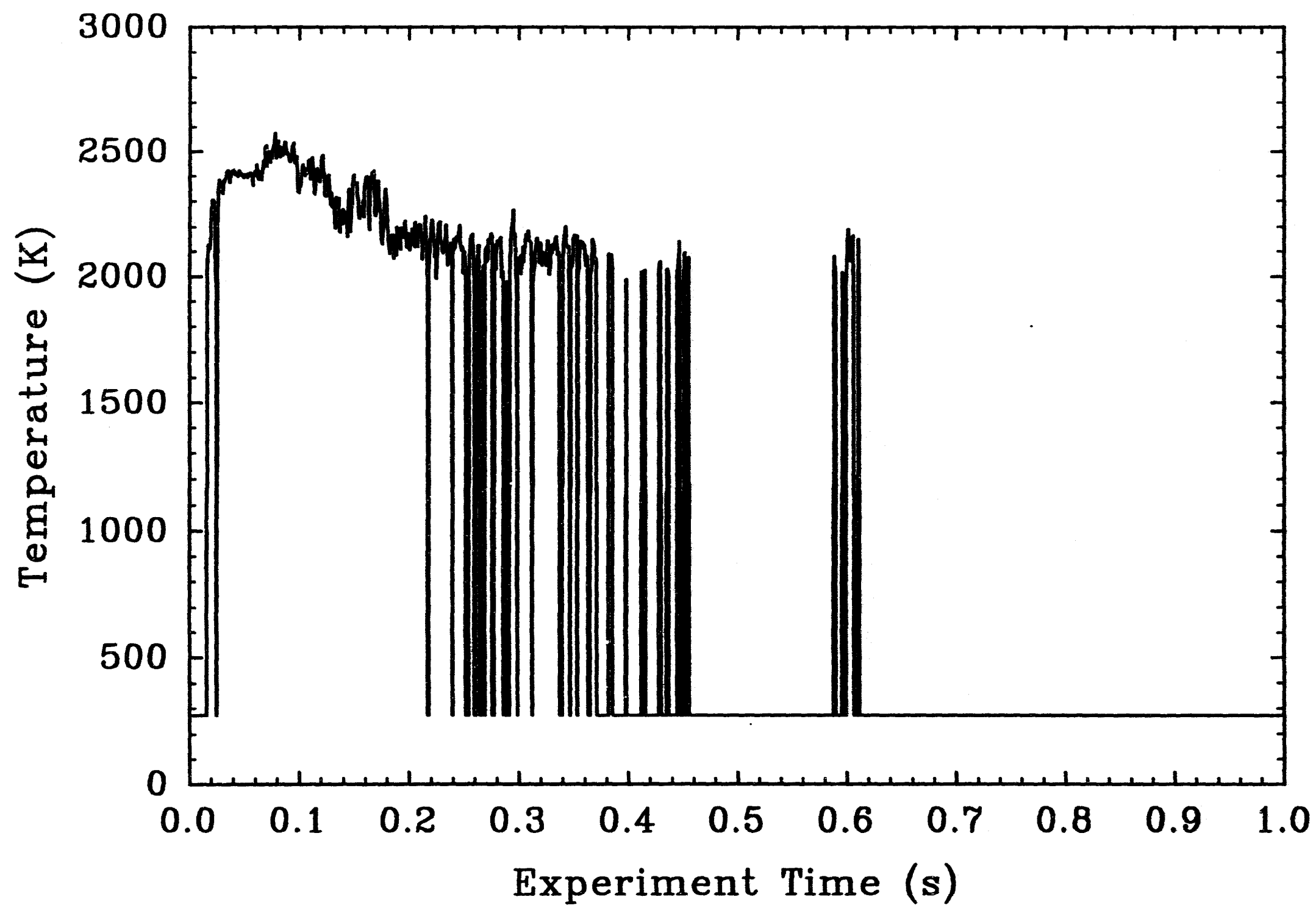

Figure 3.46 Thermite temperature measured from the bottom of the melt generator with a type $11 \times 30$ optical pyrometer for the IIT-2B experiment 


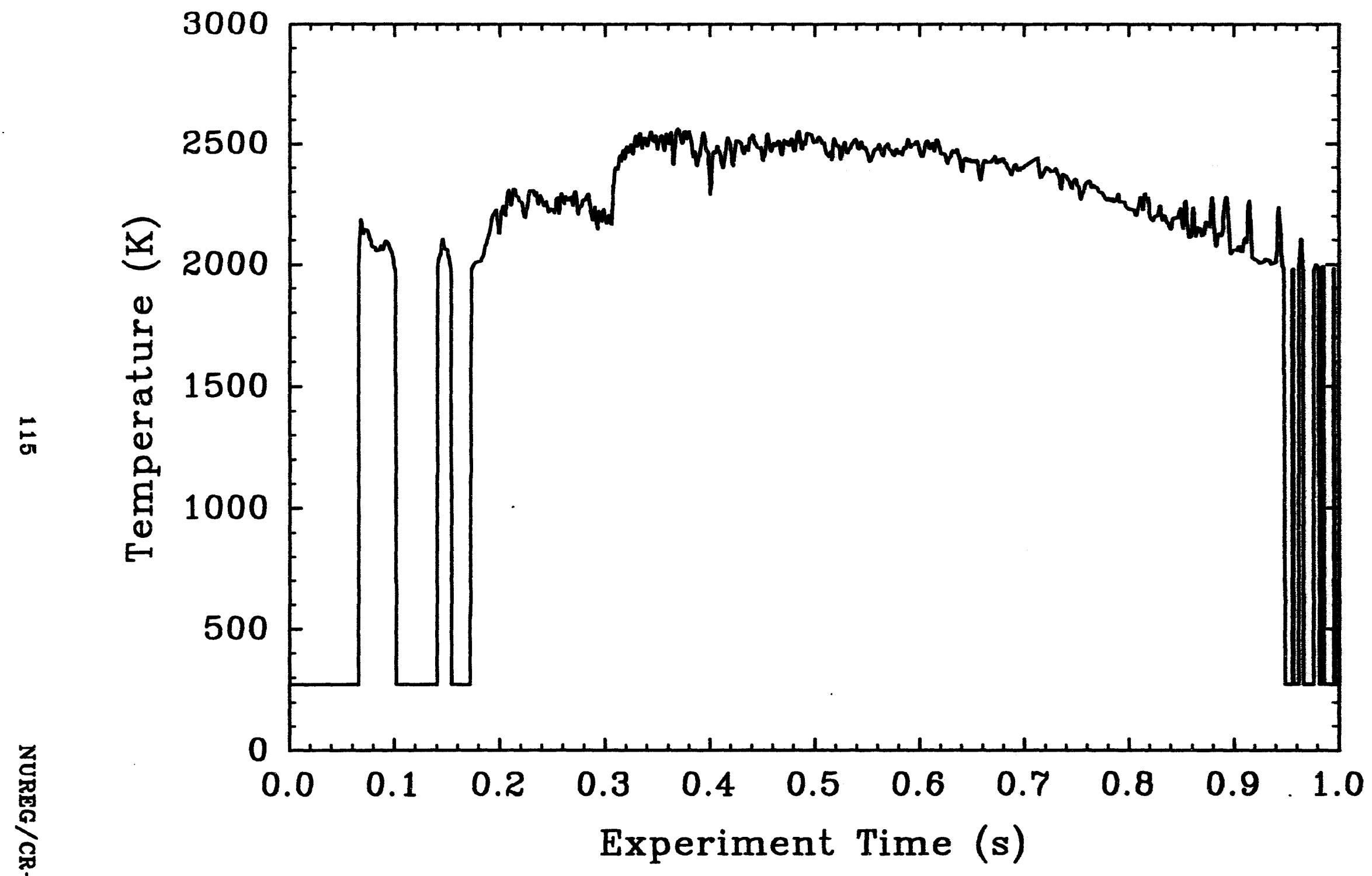

Figure 3.47 Thermite temperature measured from the bottom of the melt generator with a type $11 \times 30$ optical pyrometer for the IET-2C experiment 


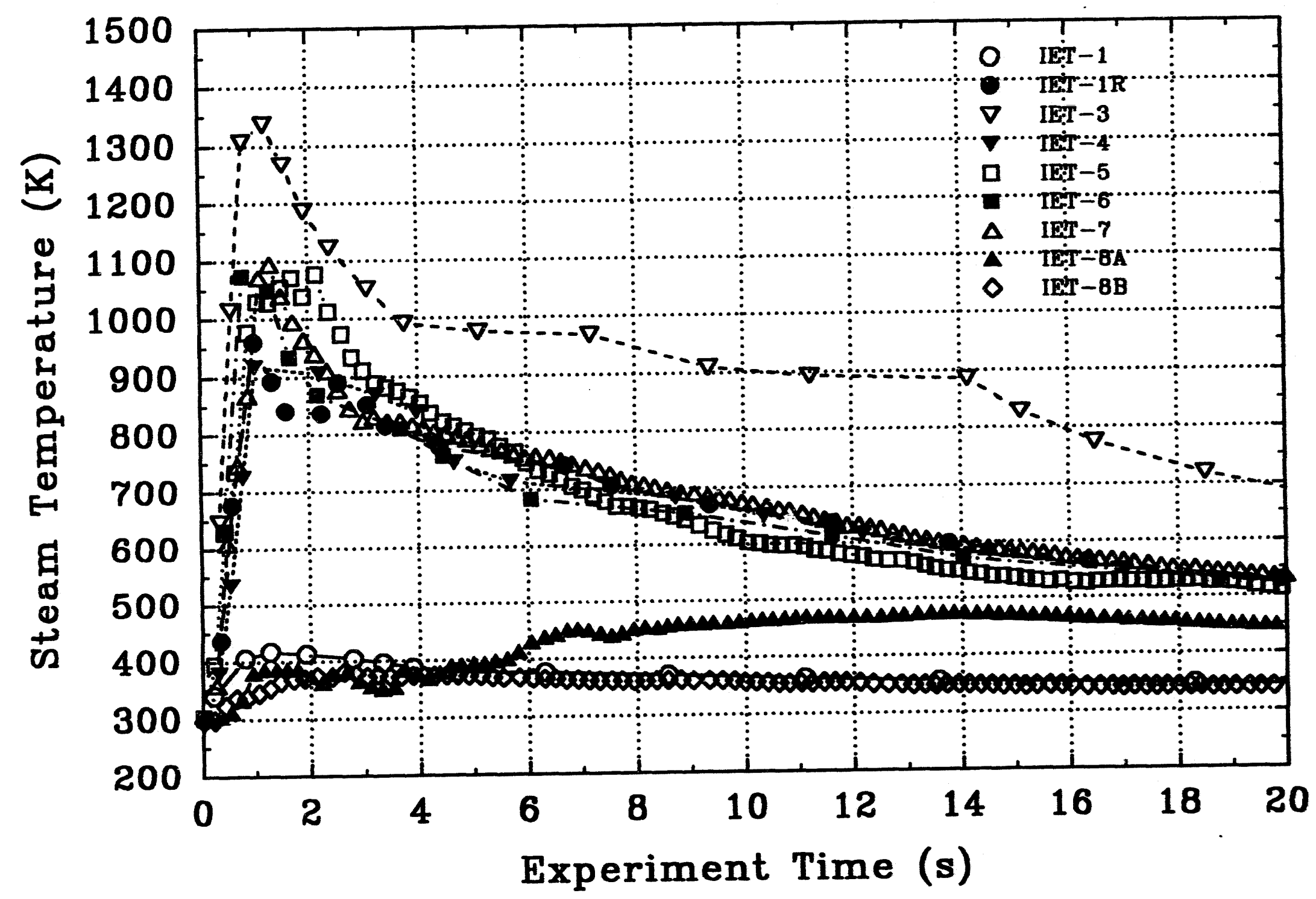

Figure 3.48 Temperature history in the triangular rent space above RCP 14 in the IET experiments 


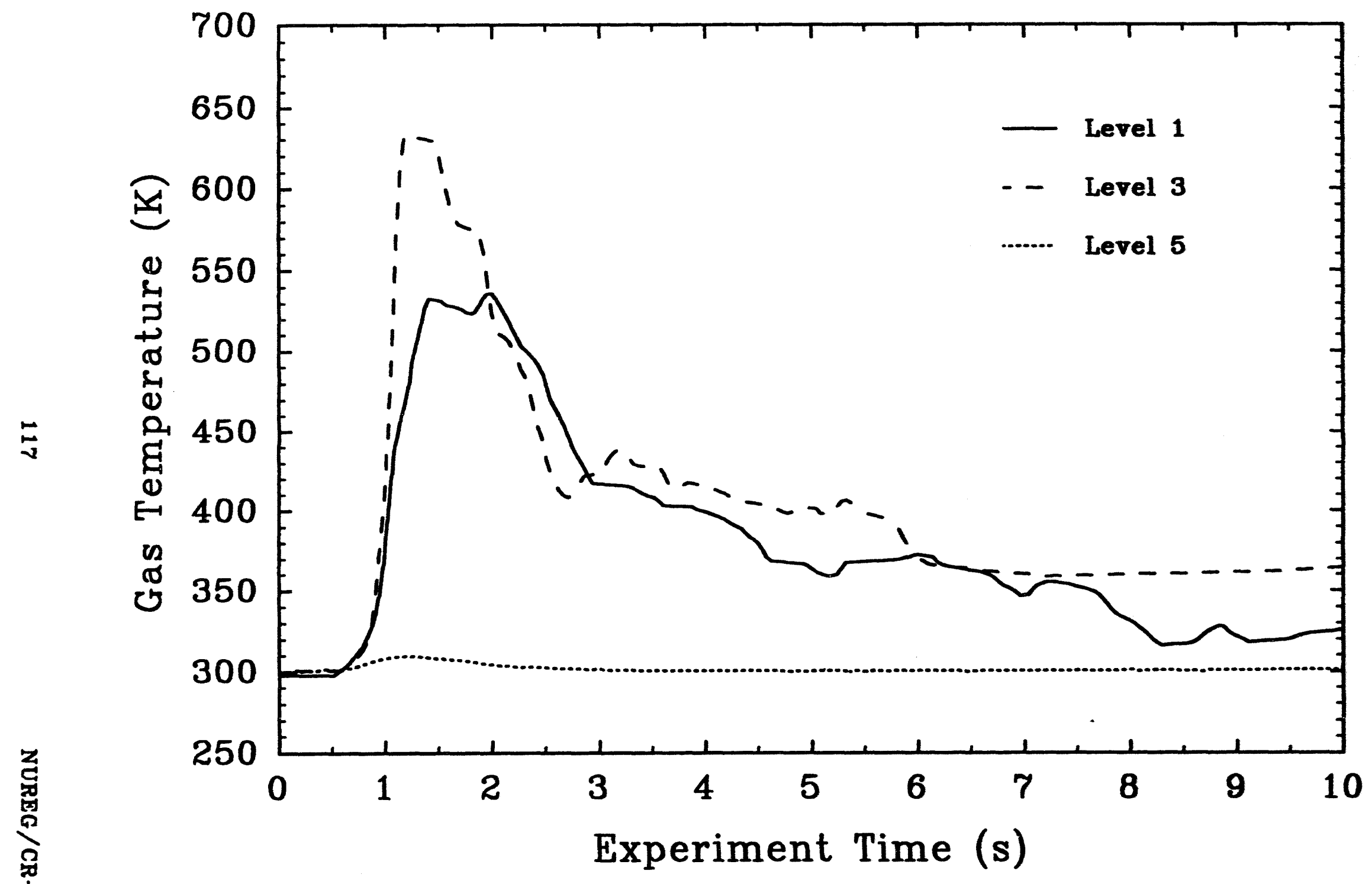

Figure 3.48 Gas temperaturea measured in the upper dome of the Surtsey ressel with aspirated thermocouples in the IET-1 experiment 


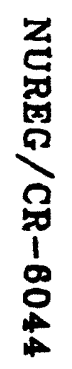

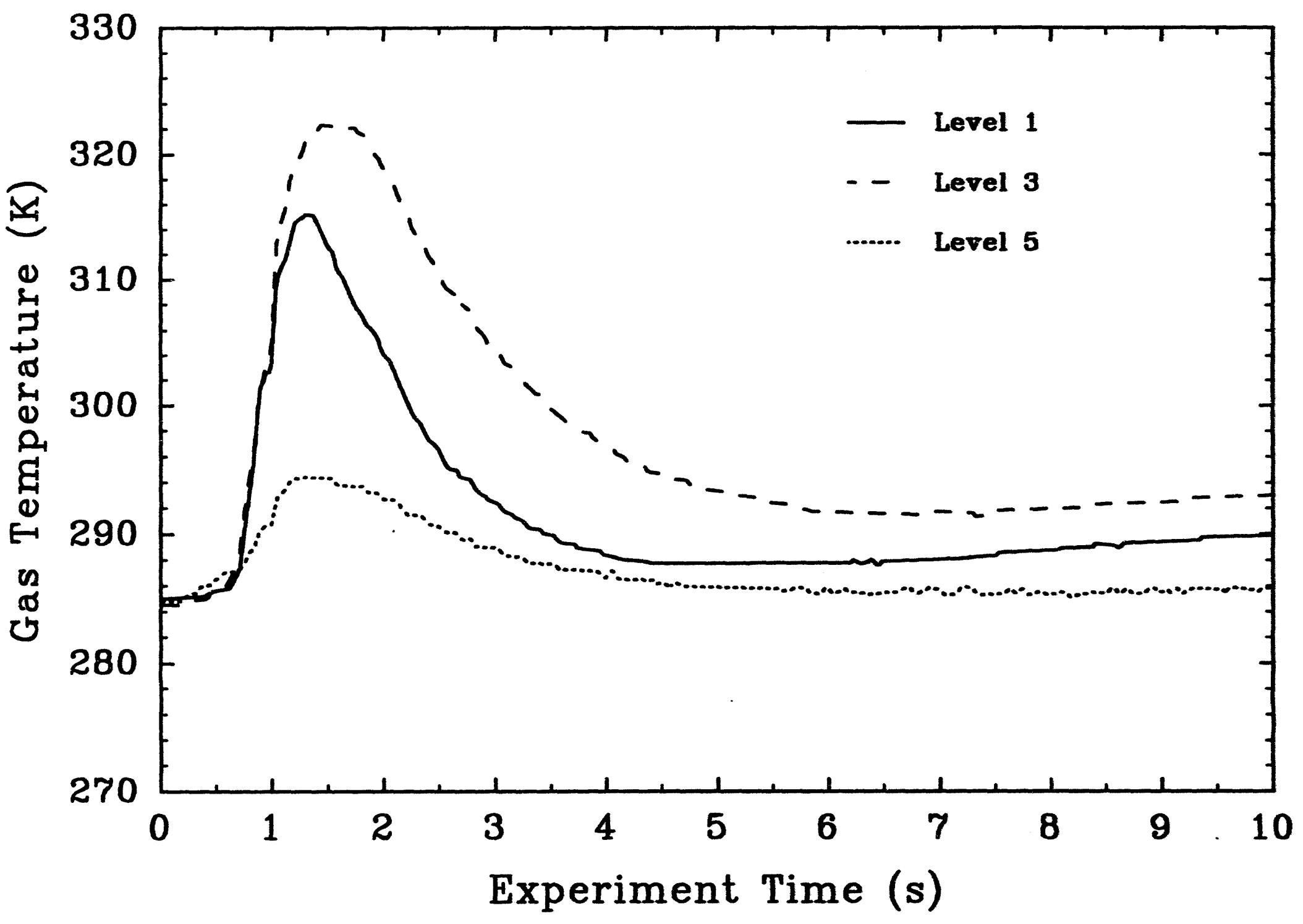

Figure 3.50 Gas temperatures measured in the upper dome of the Surtees vessel with aspirated thermocouples in the IET-1R experiment 


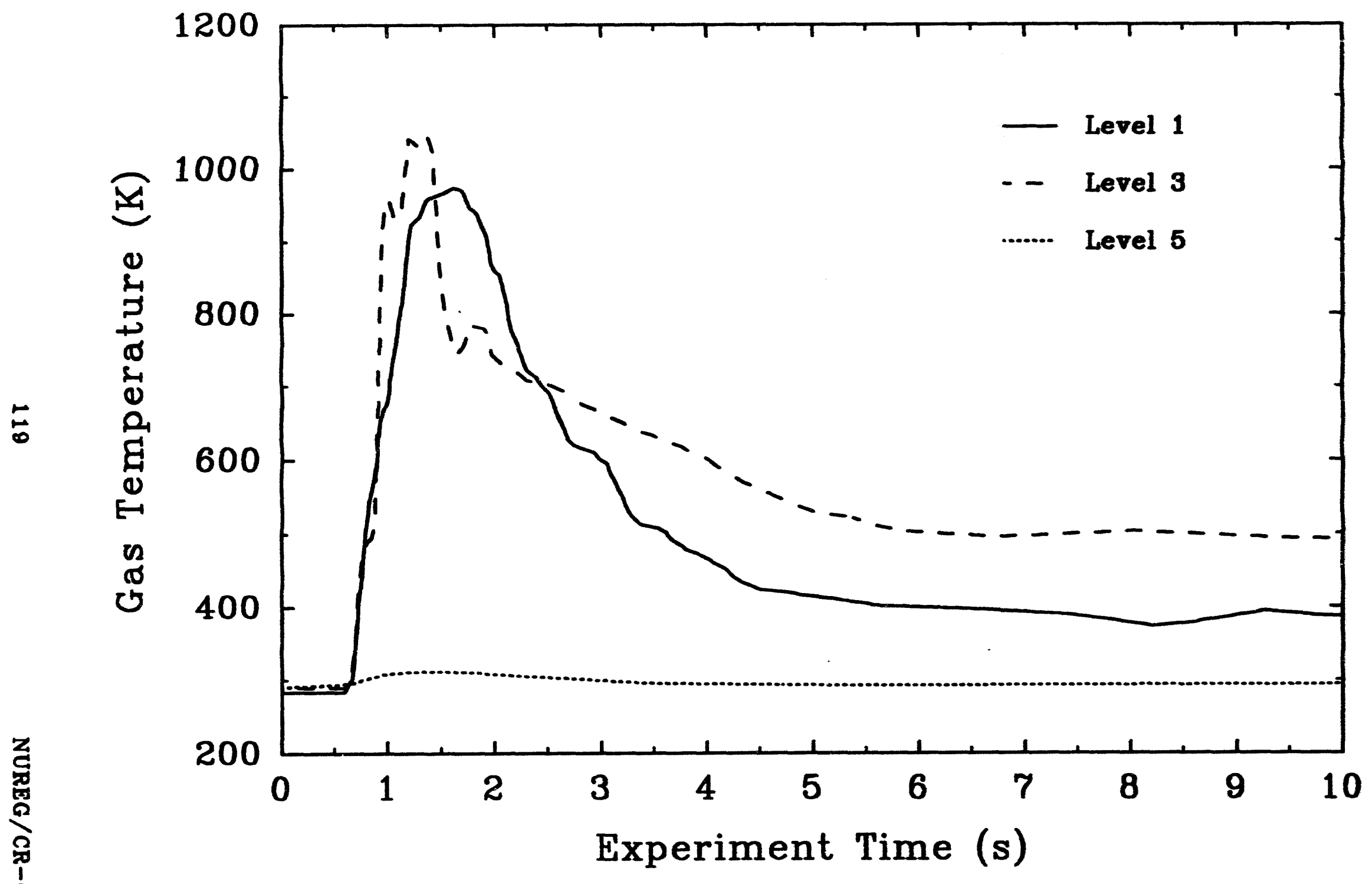

Figure 3.51 Gas temperatures measured in the upper dome of the Surtsey veasel with aepirated thermocouples in the IBT-3 experiment 


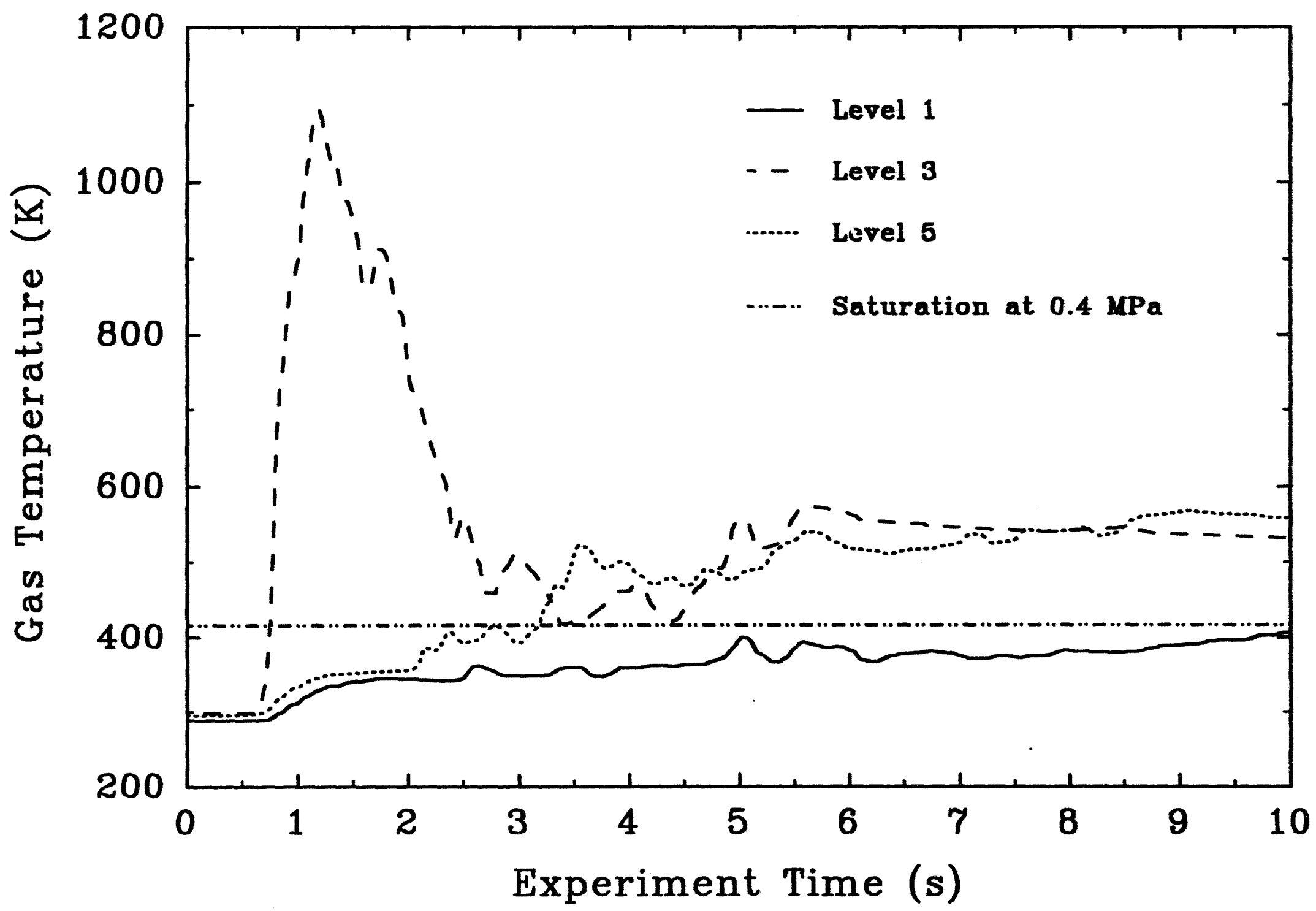

Figure 3.52 Gas temperatures measured in the upper dome of the Surtsey vessel with aspirated thermocouples in the IRT-4 experiment 


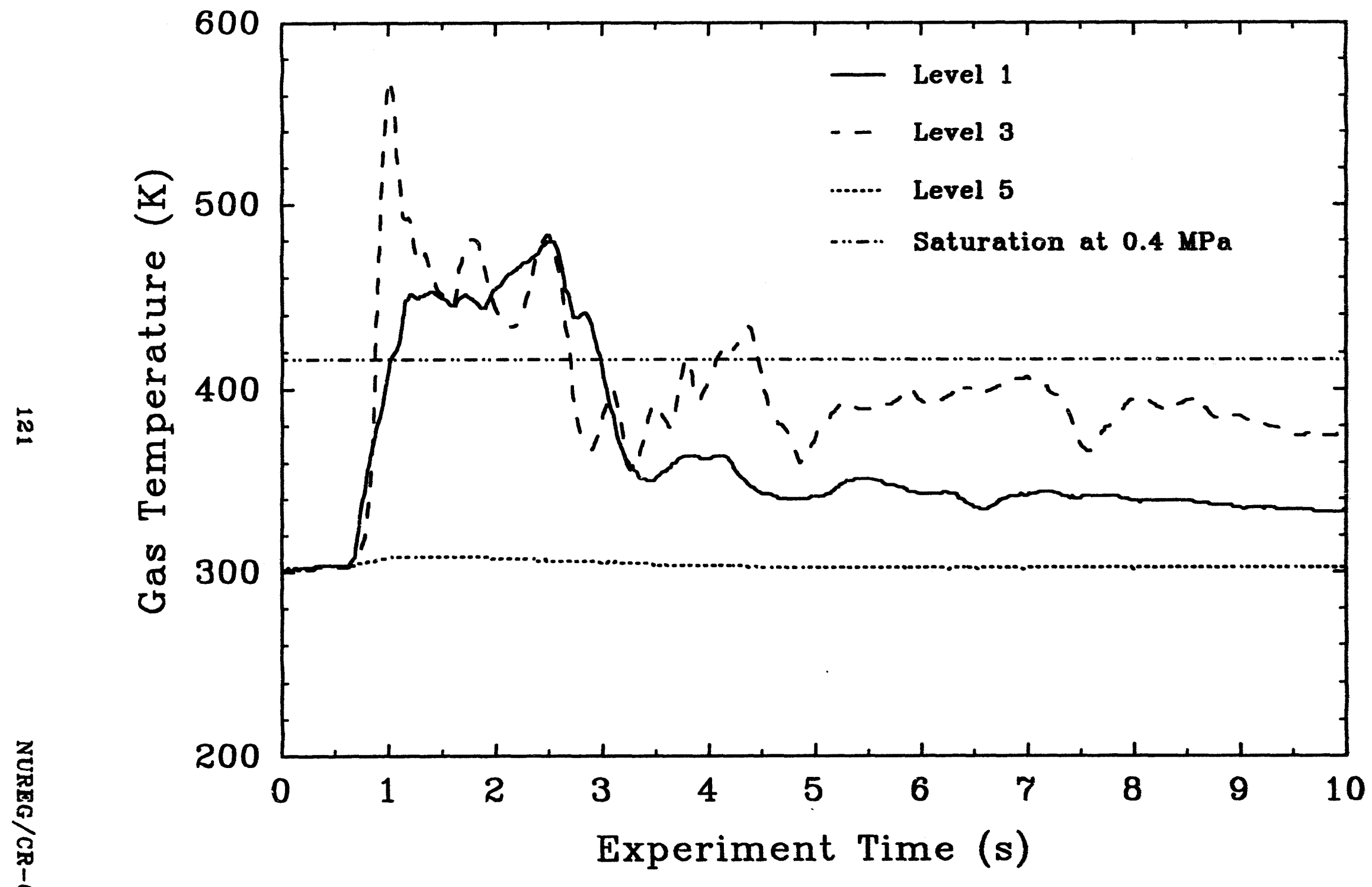

Figure 3.53 Gas temperatures measured in the upper dome of the Surtsey vessel with aspirated thermocouples in the IET-5 experiment 
Experimental Results

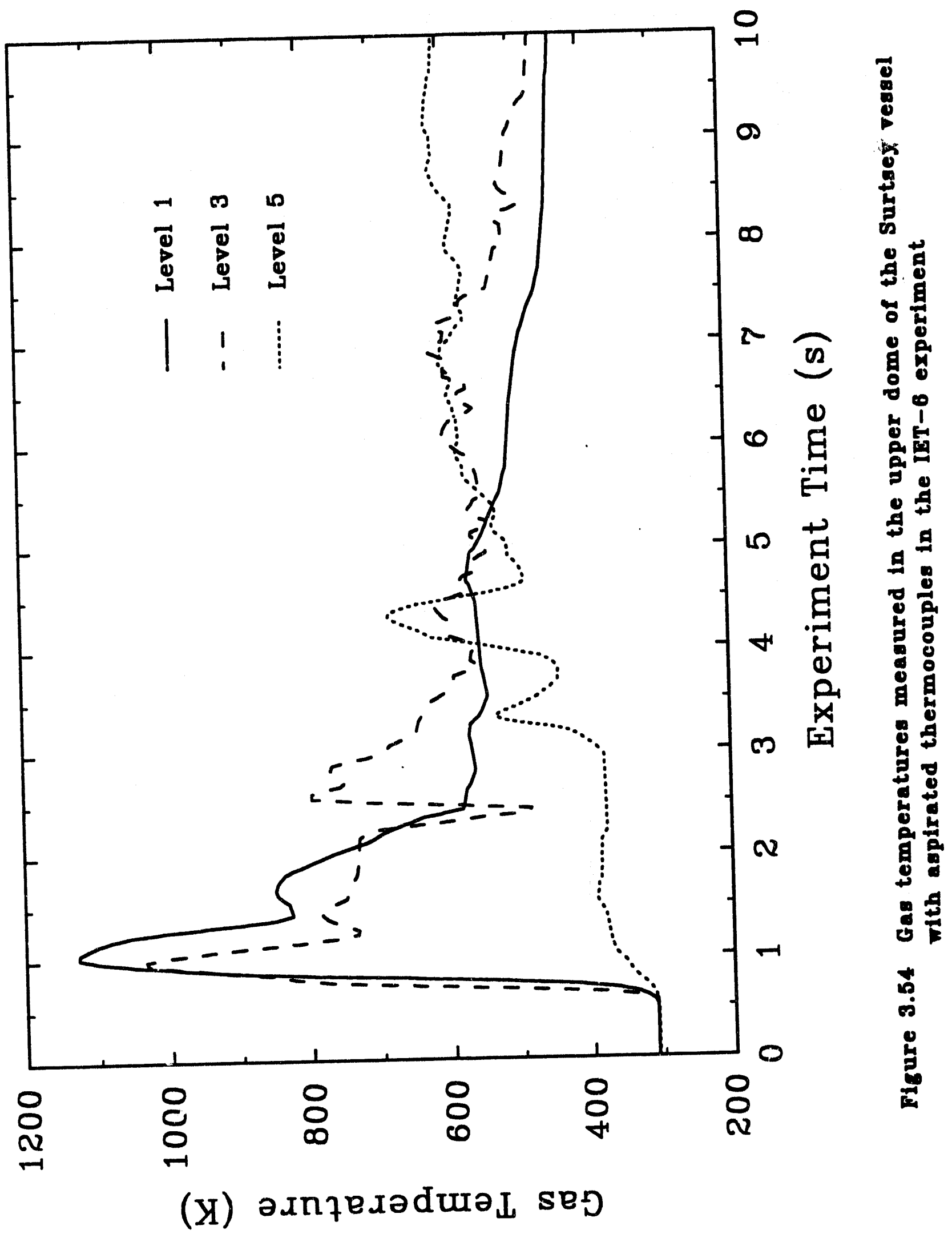




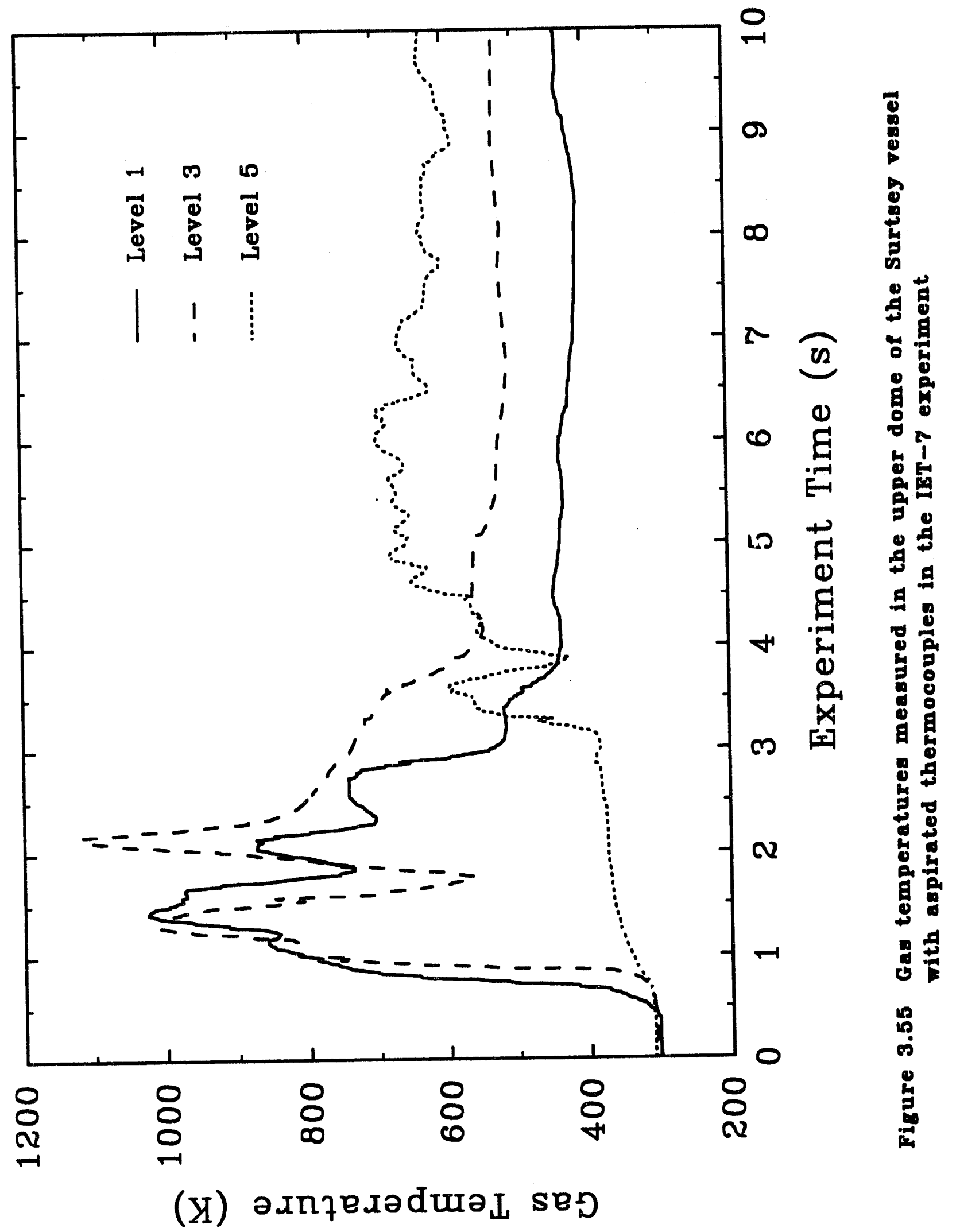




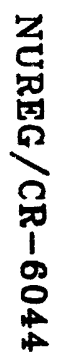

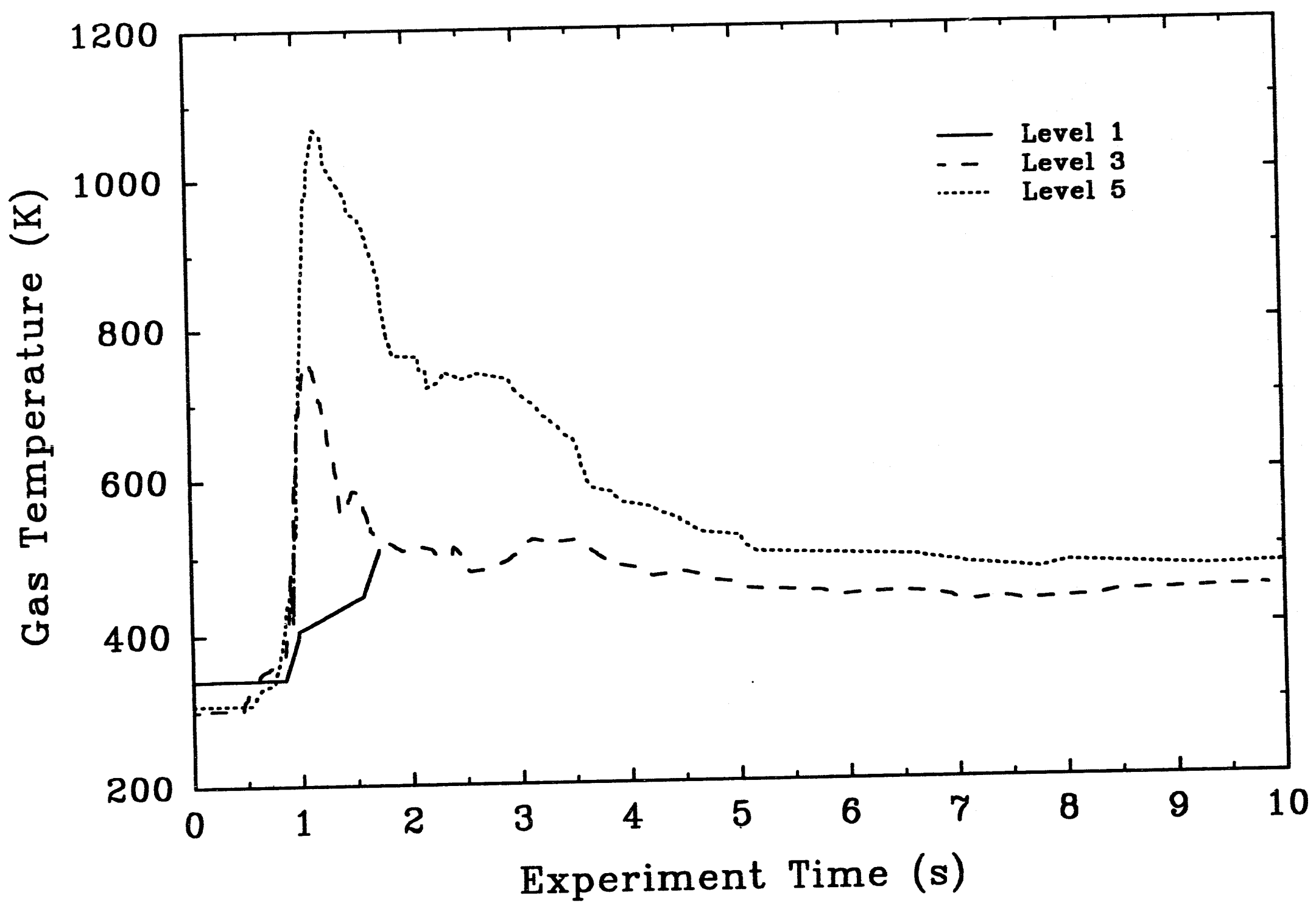

Figure 3.56 Gas temperatures measured in the upper dome of the Surtsey vessel with aspirated thermocouples in the IET-8B experiment 


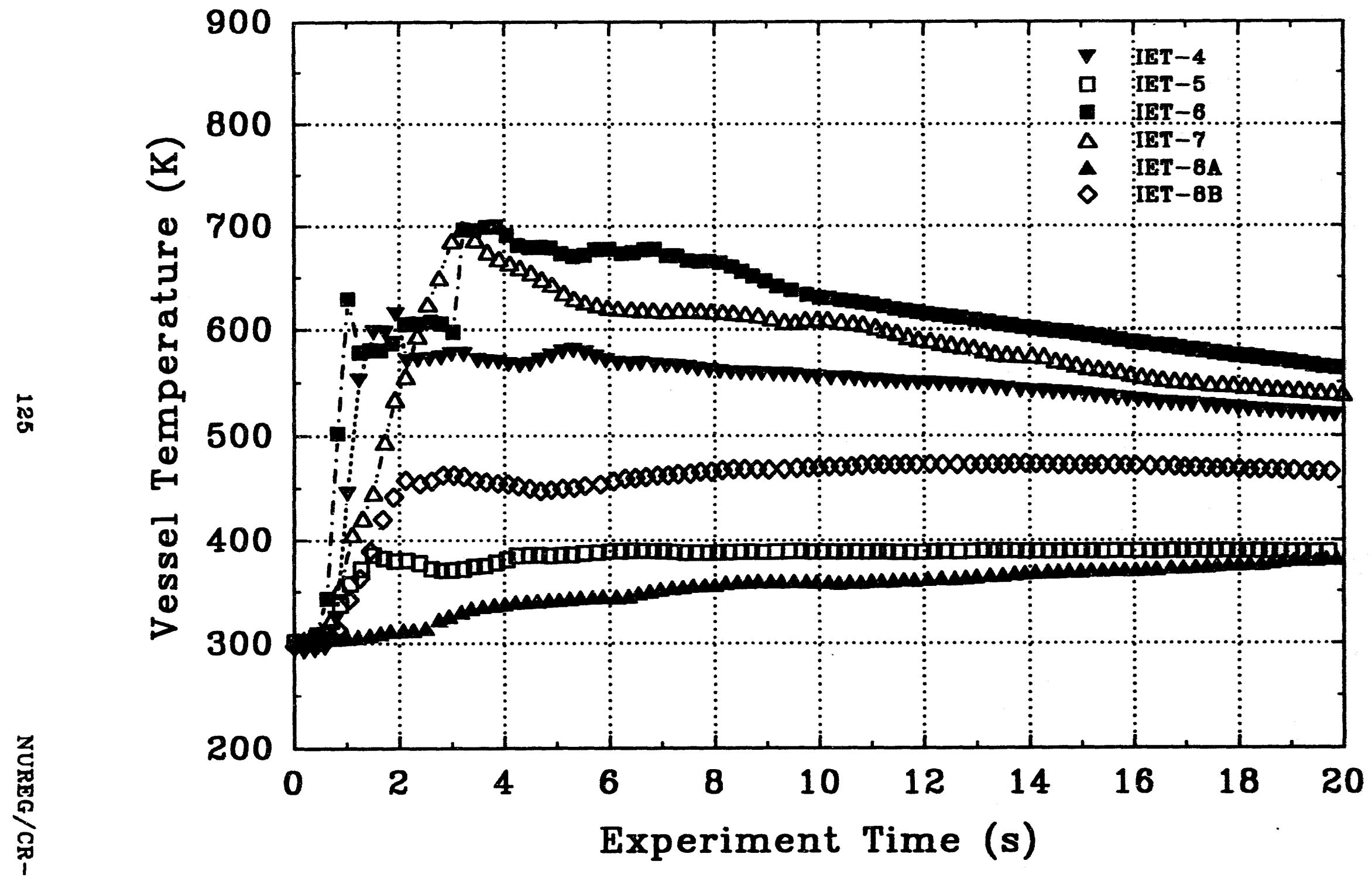

Figure 3.57 Temperature histories of the thermocouple arrays in the IET experiment: 


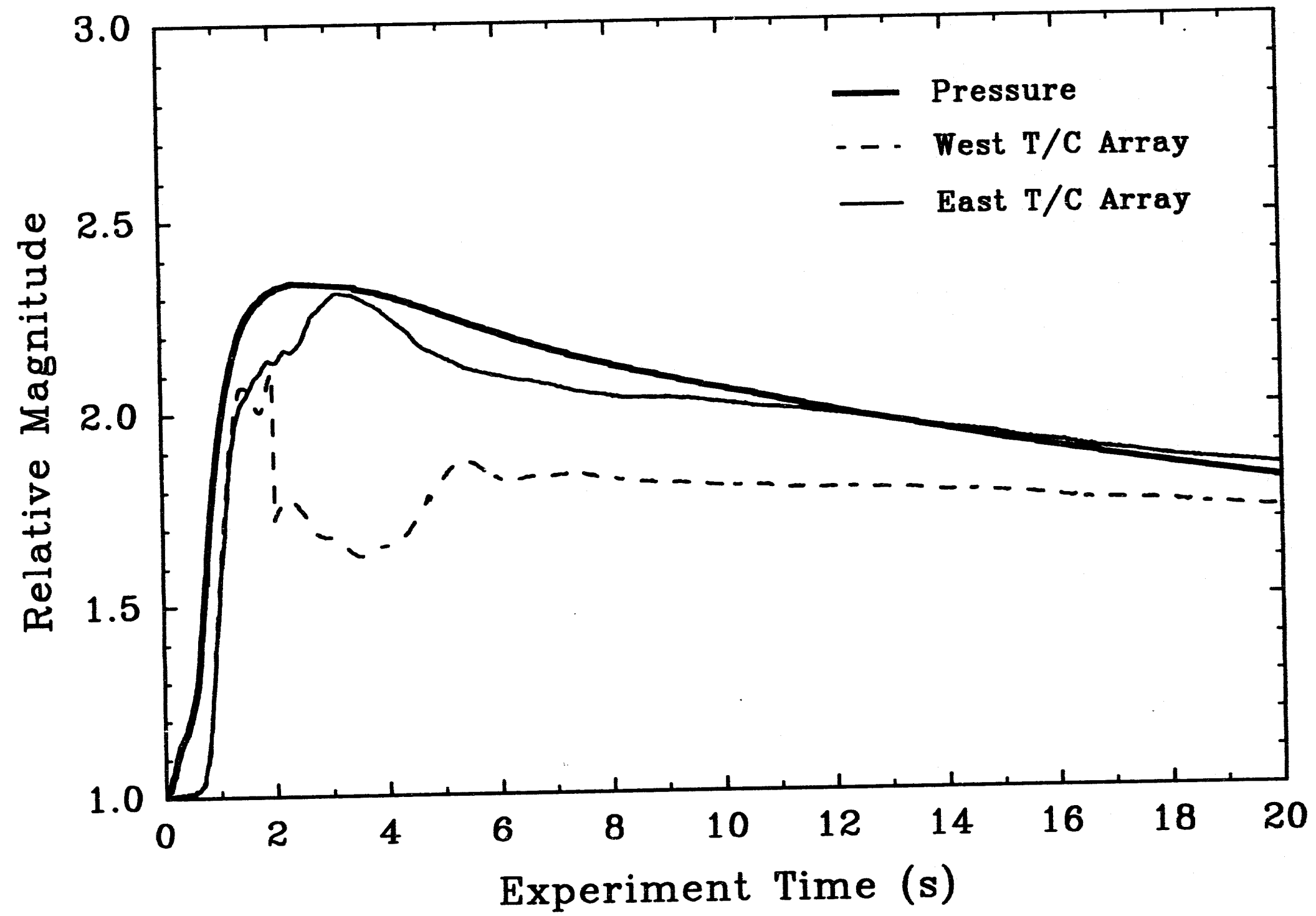

Figure 3.58 Relative pressure increase compared to the bulk gas temperature increase in the Surtsey vessel in the IET-4 experiment 


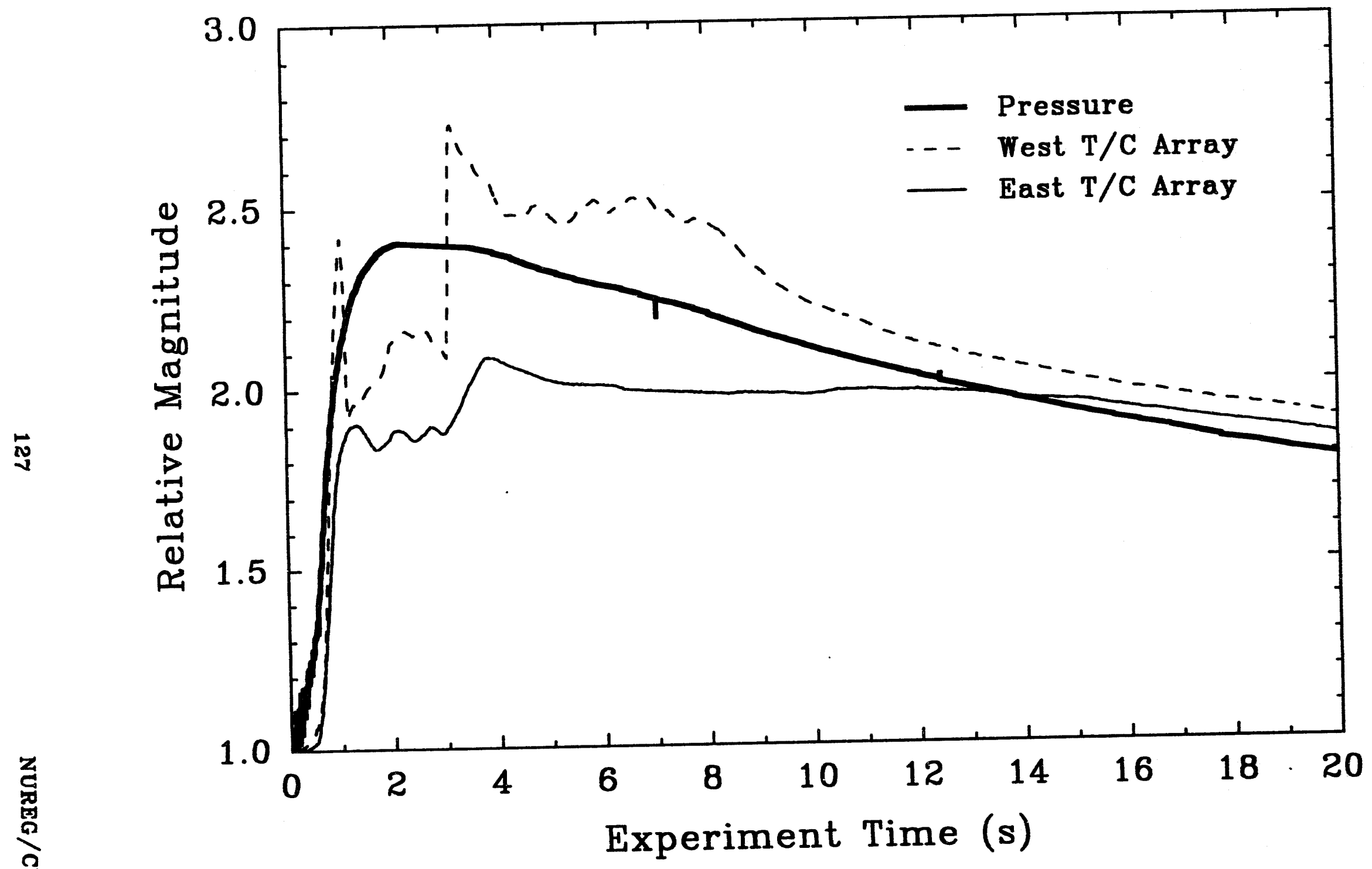

Figure 3.59 Relative pressure increase compared to the bulk gas temperature increase in the Surtsey vessel in the IBT-6 experiment 


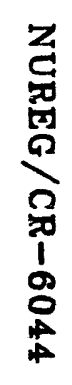

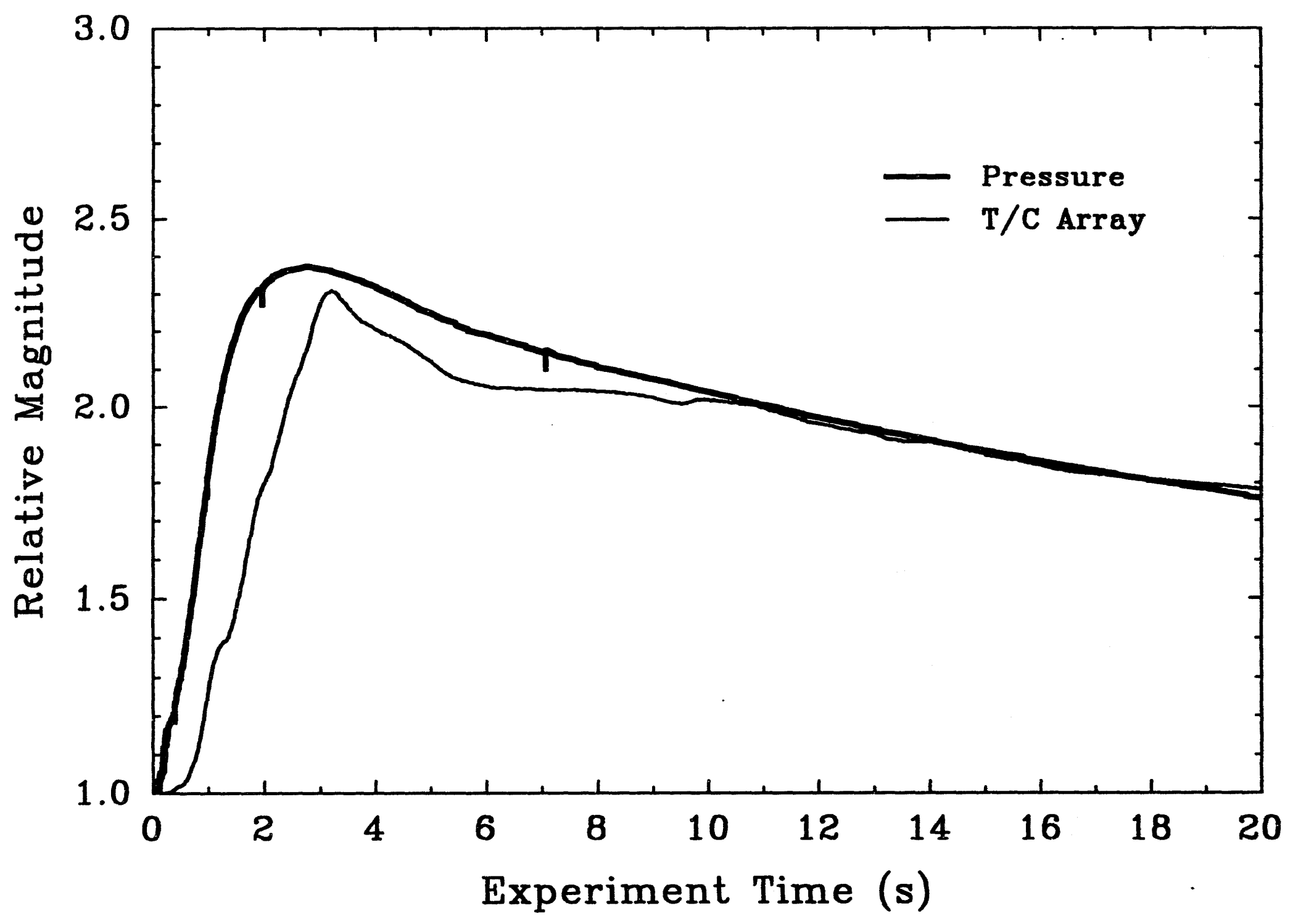

Figure 3.60 Relative pressure increase compared to the bulk gas temperature increase in the Surtsey vessel in the IET-7 experiment 


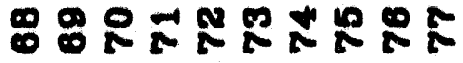

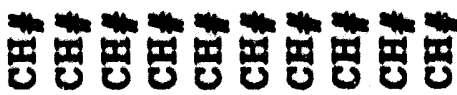

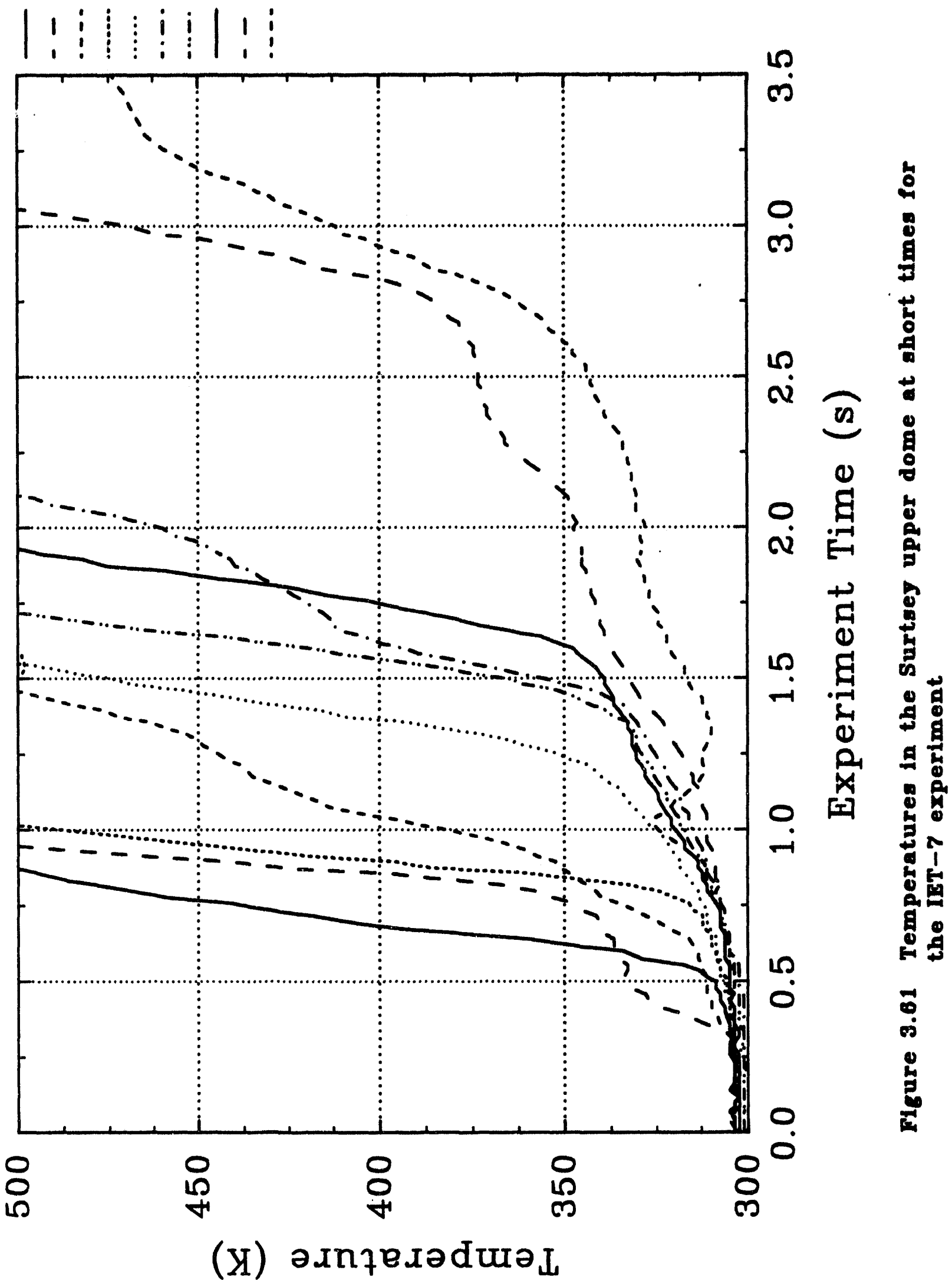




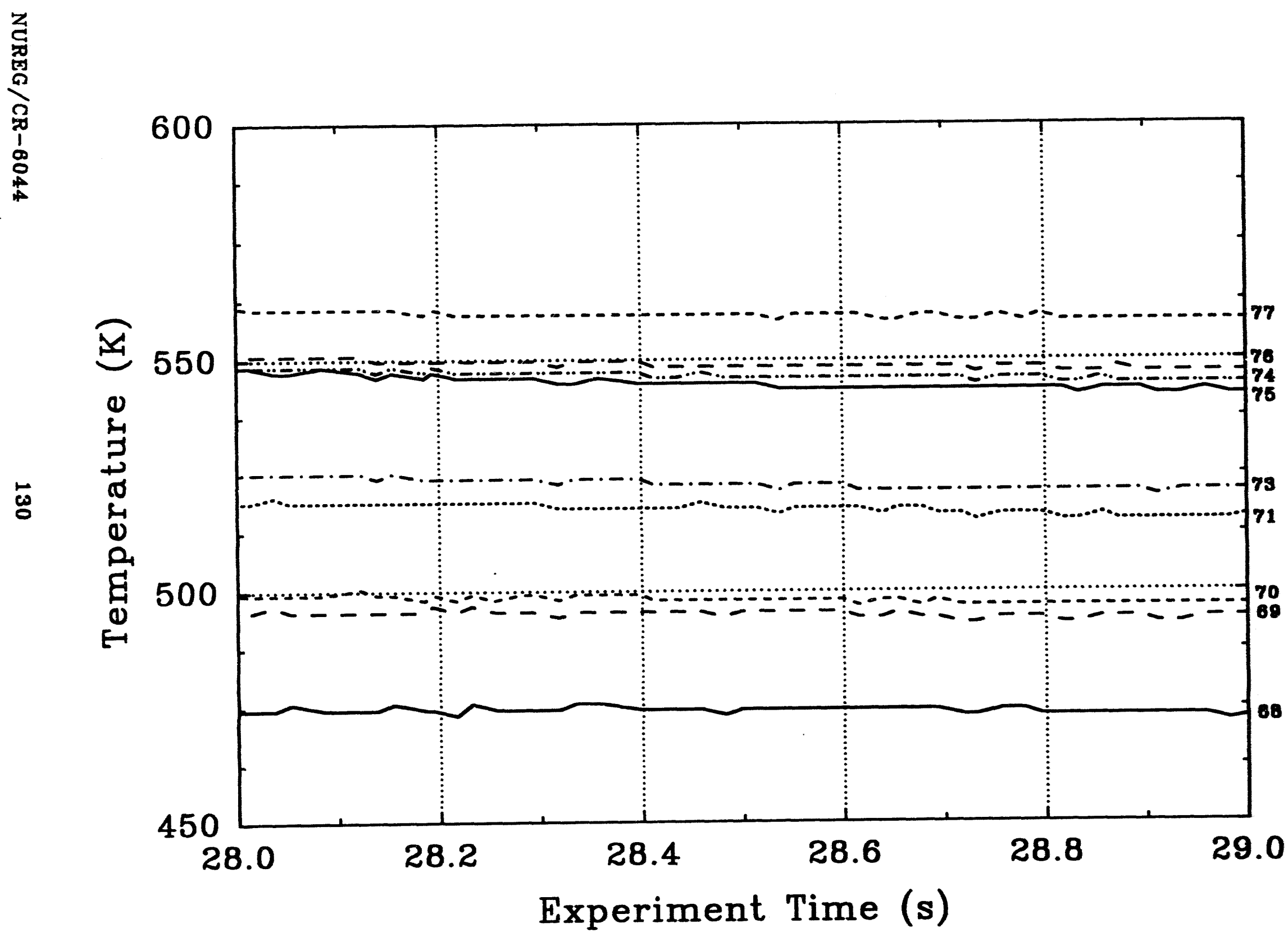

Figure 3.62 Temperatures in the Surtsey upper dome at long times after the IET-7 experiment 


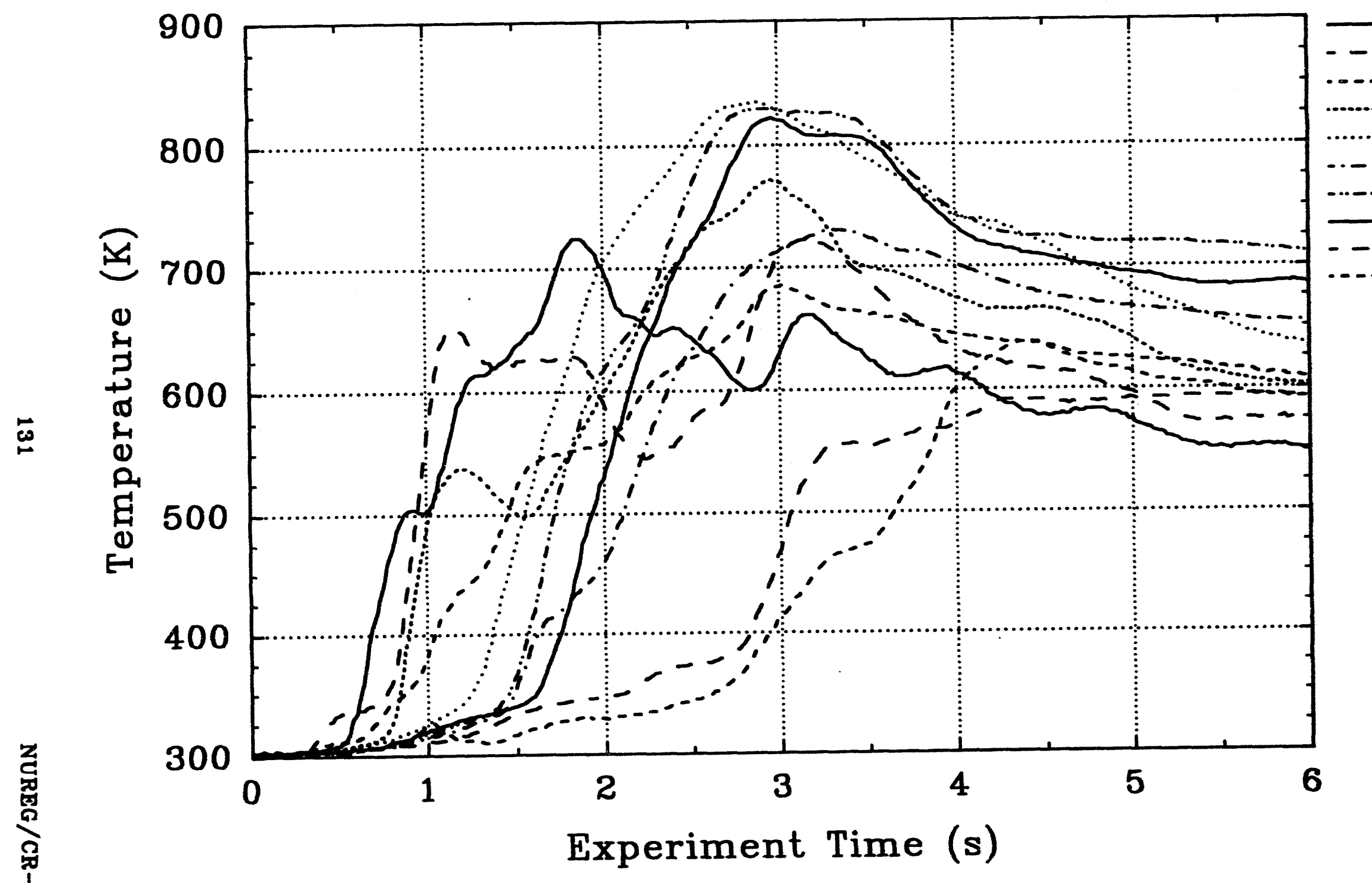

Figure 3.63 Upper dome gas temperatures for the IET-7 experiment 


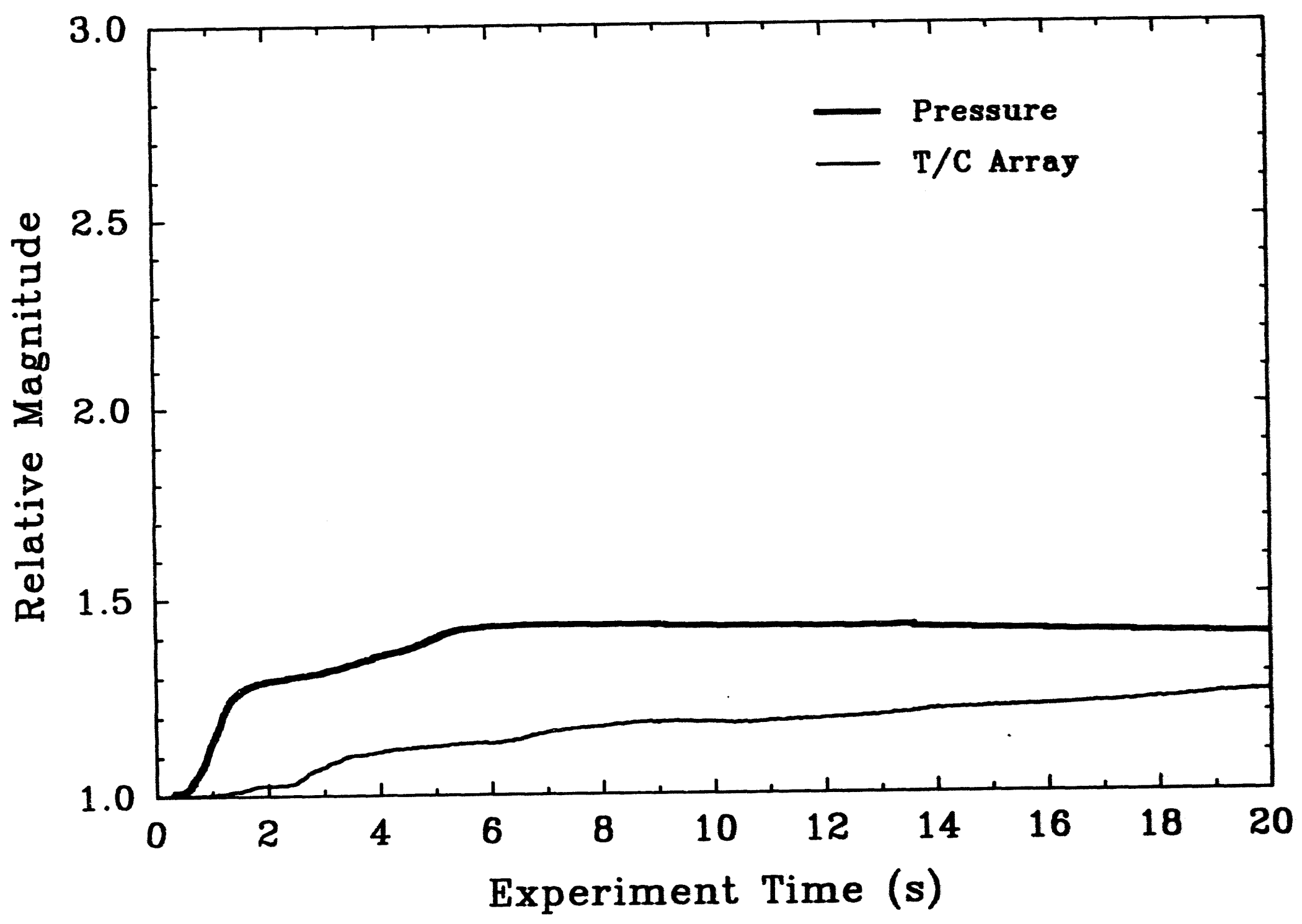

Figure 3.64 Relative presaure increase compared to the bulk gas temperature increase in the Surtsey veasel in the IBT-8A experiment 


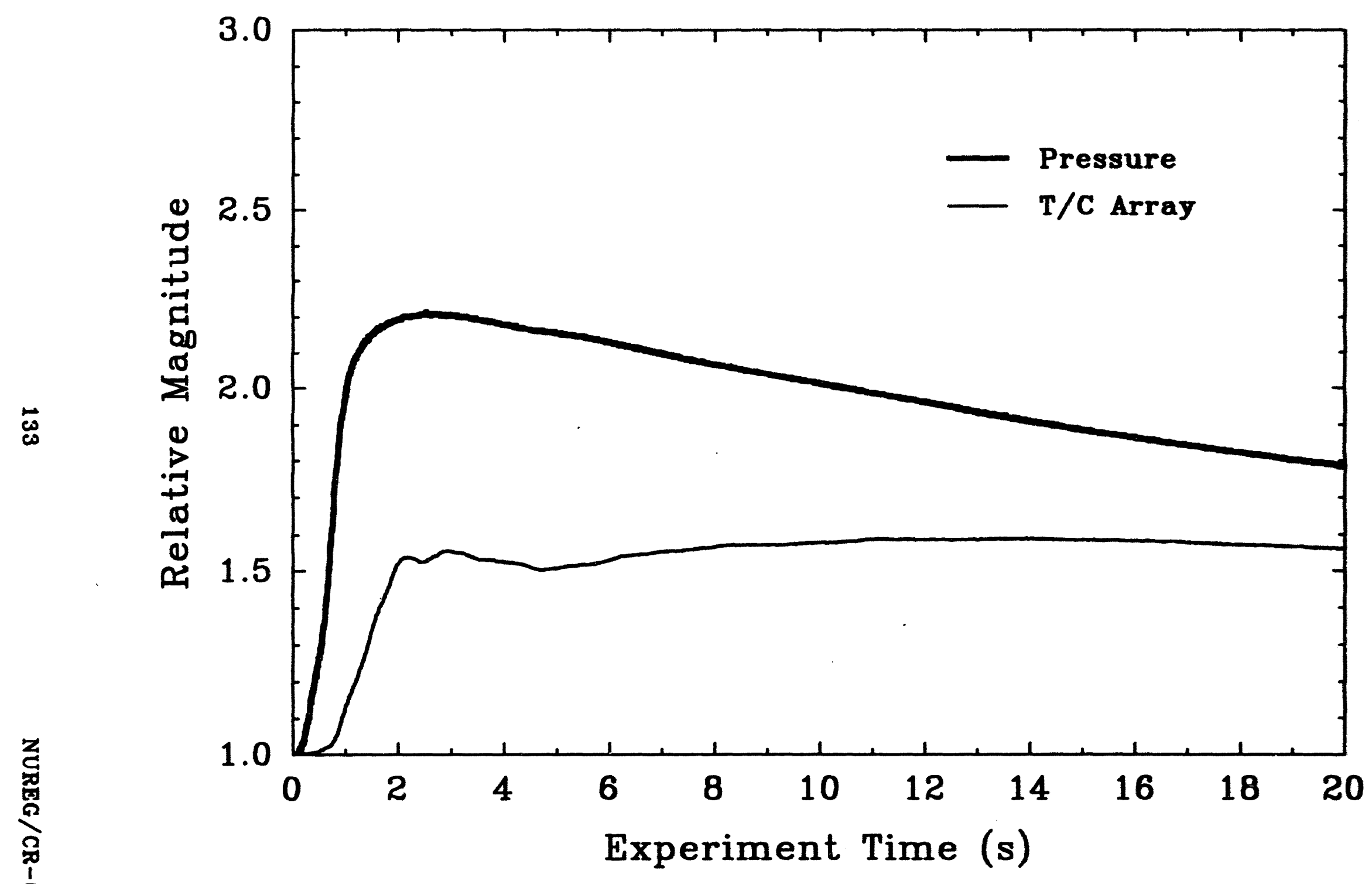

Figure 3.65 Relative pressure increase compared to the bulk gas temperature increase in the Surtsey ressel in the IET-8B experiment 


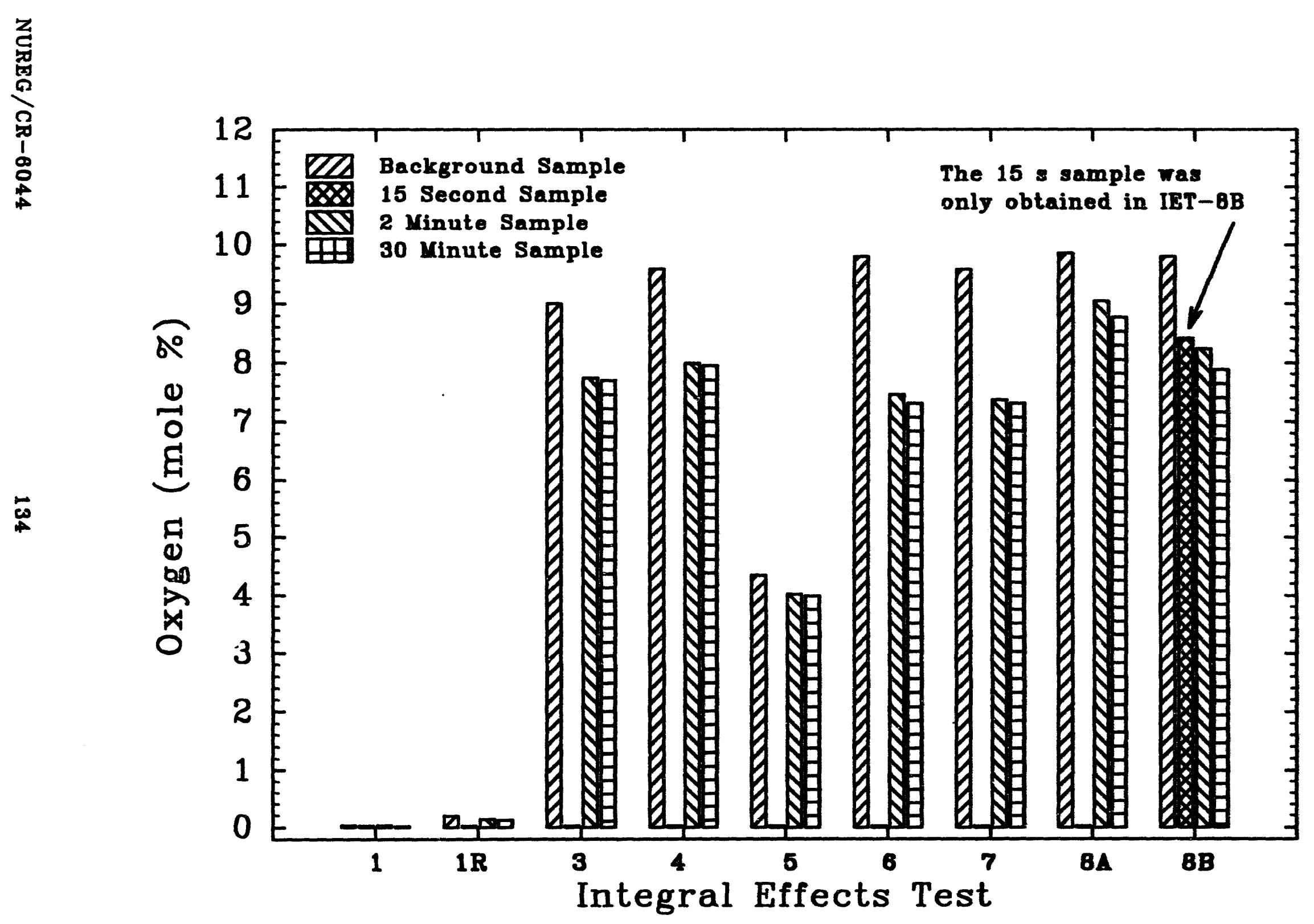

Figure 3.66 Comparison of the oxygen concentrations measured in the IET experiment. 


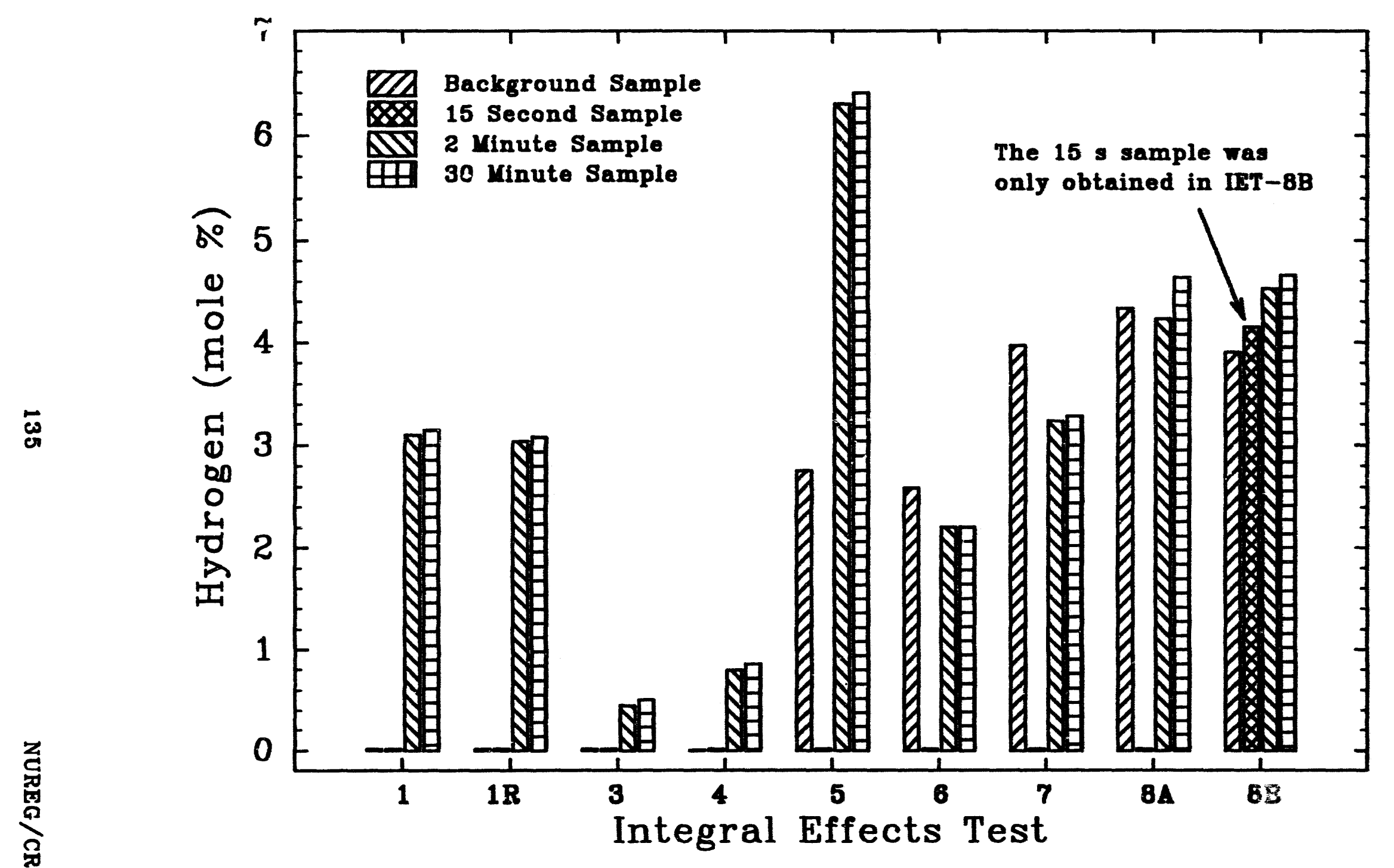

Figure 3.67 Comparison of the hydrogen concentrations measured in the IET experiments 
$z$
0
0
0
0
0
0
1
0
0
0

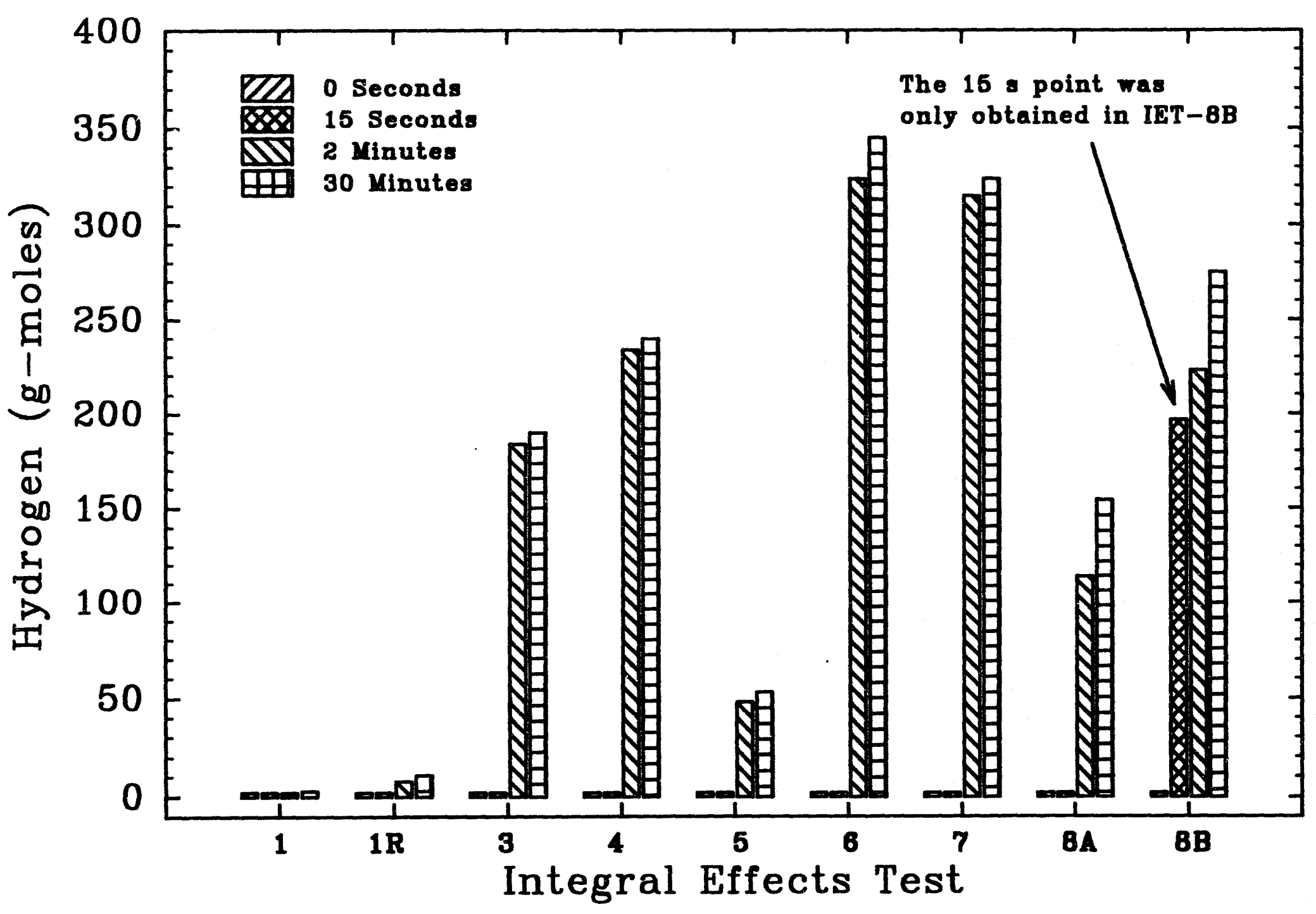

Figure 3.68 Comparison of the hydrogen combustion versus time in the IET experiments 


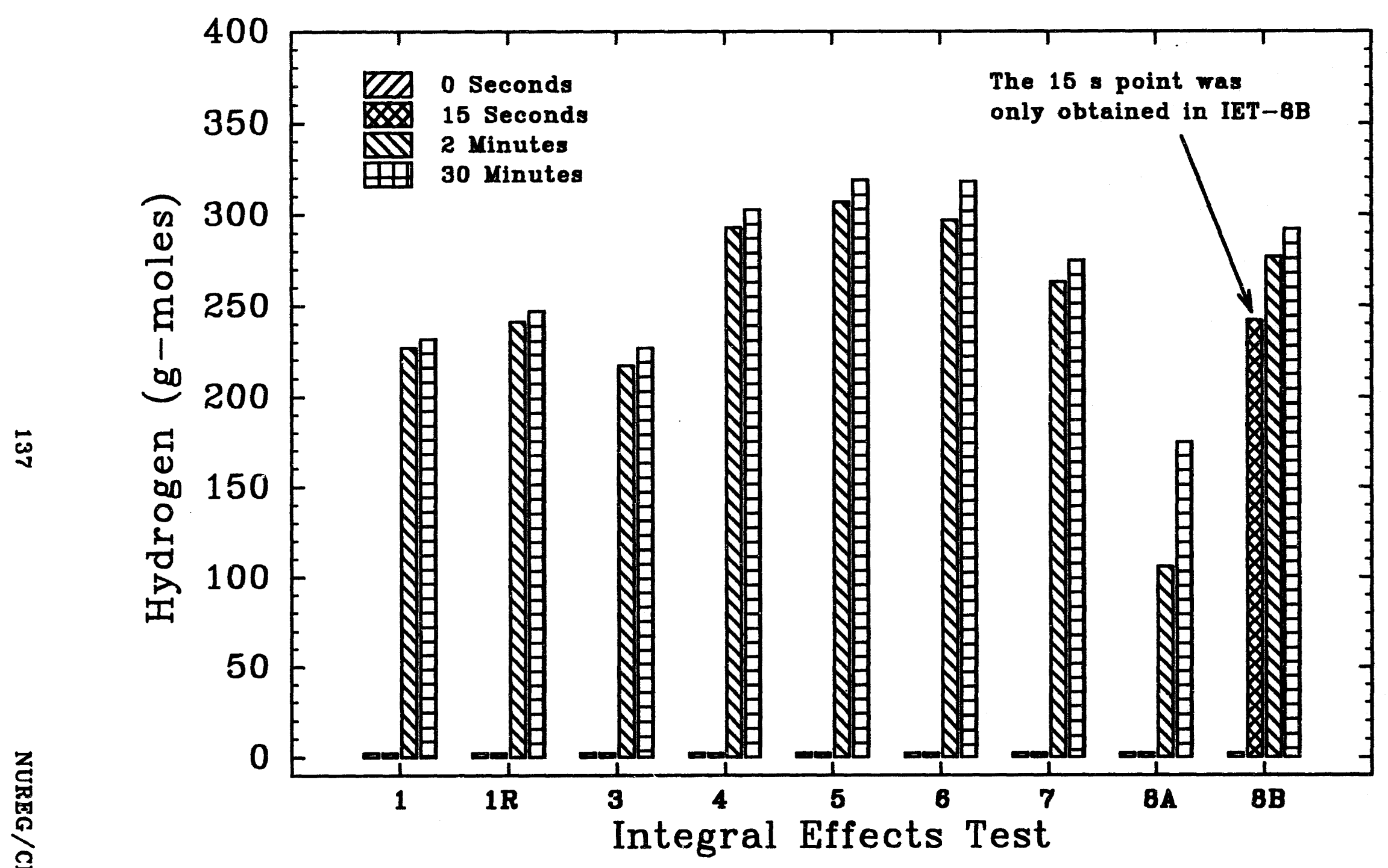

Ficure 3.69 Comparison of the hydrogen production versus time in the IET experiments 
$z$
0
0
0
0
0
0
1
0
0
0
0

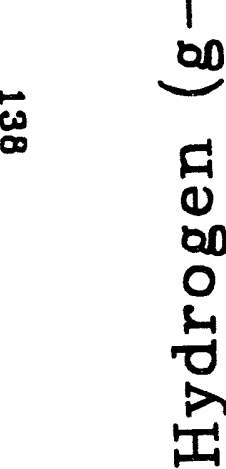

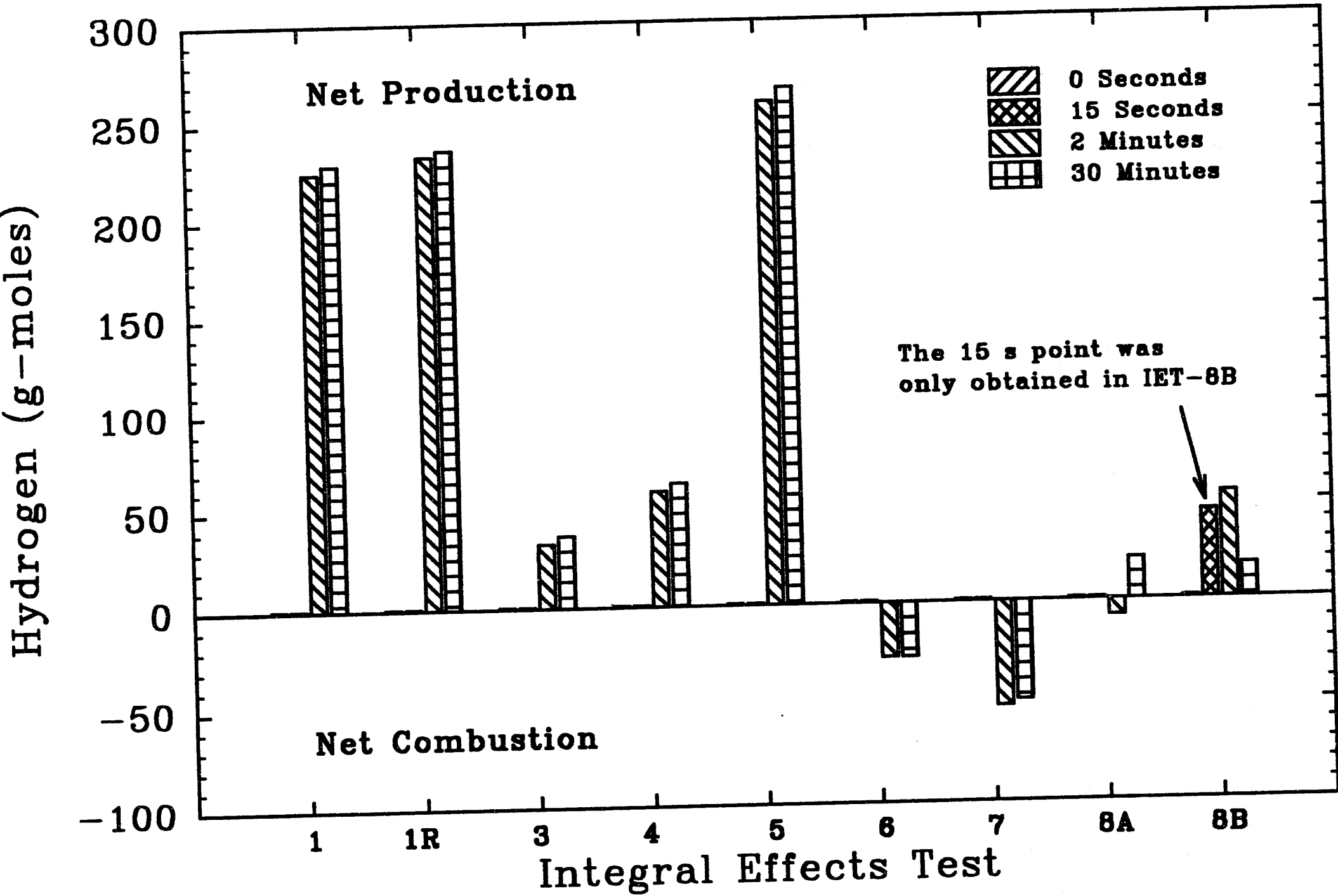

Figure 3.70 Net difference between production and combuation of hydrogen versus time in the IET experiments 


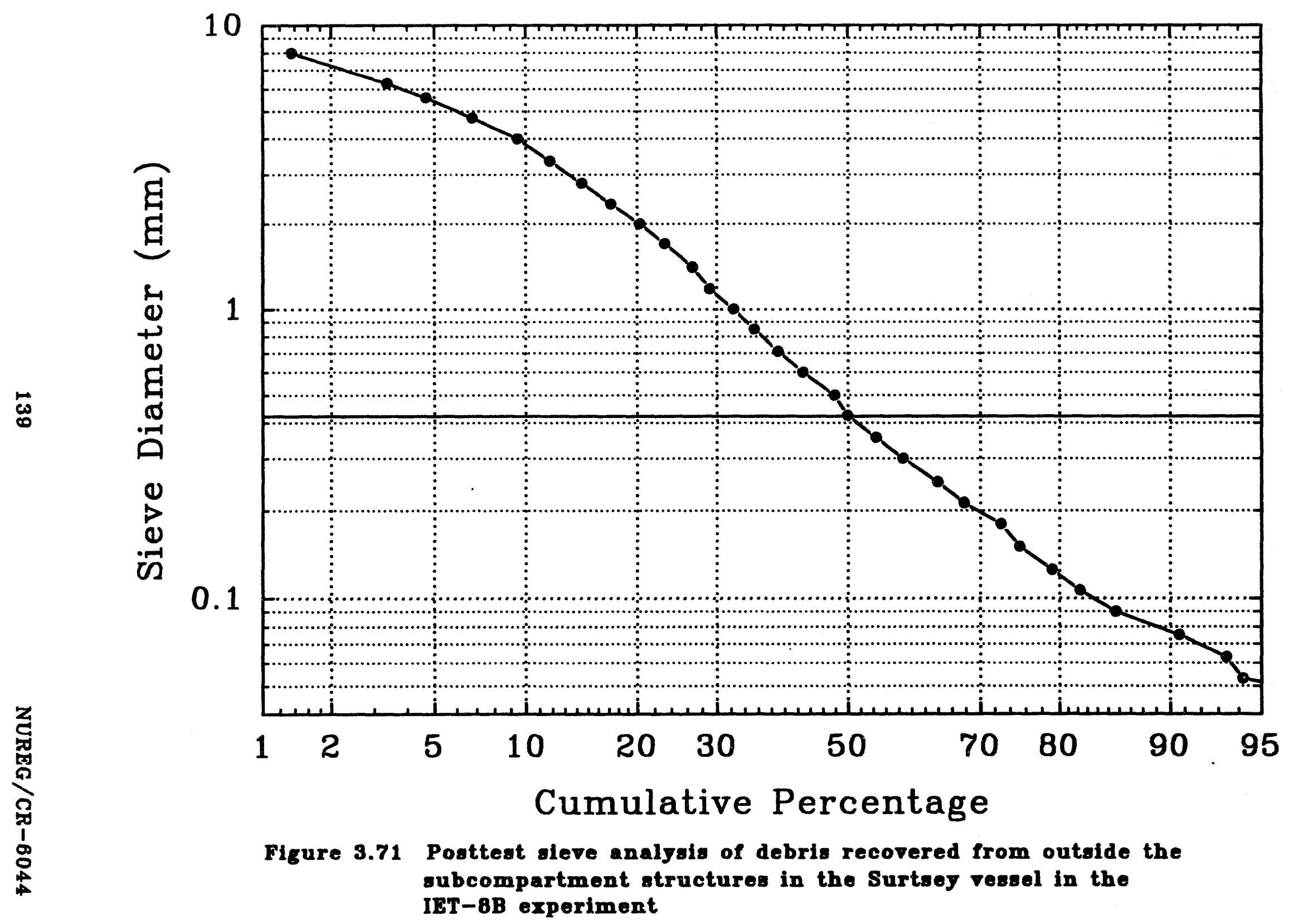




\subsection{Interpretation of Results with the Two-Cell Model}

The experiments discussed in this report are just part of an extensive DCH database. Most notably, counterpart experiments have been conducted at $\mathrm{ANL}^{6}$ at reduced physical scale. Broad conclusions can be realized by considering the current experiments in conjunction with all prior work. This is made possible because the TCE model allows data, taken under a variety of conditions, to be compared on a consistent basis.

The TCE model, developed in Appendix A, is used to interpret the results of the IET experiments. The premise of the TCE model is that there is only a limited amount of gas with which the debris can interact. Containment compartmentalization plays a crucial role in trapping debris once it leaves the cavity. Consequently, debris interactions are largely limited to the blowdown gas and possibly some subcompartment atmosphere. Further mitigation is realized because dispersed debris can only interact with blowdown gas that is coherent with the dispersal process in the cavity.

\subsection{Computation of the Coherence Ratio}

The coherence ratio determines how much blowdown gas has been vented from the RCS on the same time scale as debris dispersal. Figure 4.1 shows a typical blowdown curve from an experiment. Generally, three phases can be distinguished: single-phase liquid discharge, twophase discharge, and single-phase gas discharge. The entrainment interval is determined primarily from the cavity pressurization record, which (after subtracting the containment pressure) is overlayed on the blowdown curve (Figure 4.1). Pyrometers placed at the cavity exit confirm that the cavity pressurization record is a meaningful

\footnotetext{
6 J.L. Binder et al., 1992a-f, Ouick Look Datn Report on the Interal Effects Teats IIR, IRR, 3,6, 7, 81 in the Corexit Fecility at Arronne National Laboratory, draft for review, Argonne National Laboratory, Argonne, II.
}

measure of the entrainment interval [Allen et al. 1991b]. The end of the entrainment interval is marked by $\tau_{c}^{\prime}$ and corresponds to a final pressure $P_{e}$ in the RCS. The decline in RCS pressure over the entrainment interval is a direct measure of the amount of gas vented into the cavity, and for an isentropic expansion within the RCS,

$$
f_{\text {coth }}=\frac{\Delta M_{z}}{M_{z}^{0}}=1-\frac{M_{g, e}}{M_{z}^{0}}=1-\left[\frac{P_{e}}{P^{\circ}}\right]^{1 / \gamma}
$$

where

$$
\begin{aligned}
& f_{\text {coth }}=\text { fraction of RCS gas vented to the } \\
& \mathbf{M}_{z}^{\circ}=\text { initial gas mass in the RCS, } \\
& \mathbf{M}_{2,0}=\text { gas mass remaining in the RCS at } \\
& \text { the end of the dispersal interval, } \\
& \mathbf{P}^{\circ}=\text { initial RCS pressure, } \\
& P_{e}=\text { RCS pressure at the end of the } \\
& \text { dispersal interval, and } \\
& \gamma=\text { isentropic exponent. }
\end{aligned}
$$

This expression applies even though depressurization passes through three distinct phases. For computational convenience, it is useful to idealize the blowdown process as a single-phase gas discharge from a fixed size orifice (after any possible ablation). For isentropic expansion in the RCS and isentropic nozzle flow, the blowdown history can be approximated by

$$
\frac{P}{P^{0}}=\left[1+\frac{\gamma-1}{2} \frac{t}{\tau_{b}}\right)^{\frac{2 \gamma}{\gamma-1}}
$$


where $t$ is the time since the start of blowdown, and the characteristic blowdown time is given by

$$
\tau_{b}=\frac{M_{z}^{0}}{\dot{M}_{B}^{0}} \text {. }
$$

Physically, the pressure will be reduced to 29 percent of its initial value $(\gamma=1.33)$ after one time constant, and 61 percent of the initial gas mass will have been vented from the RCS.

The effective coherence ratio, assuming an idealized blowdown that is consistent with the measured depressurization over the entrainment interval, is obtained from equation 4.2,

$$
\frac{\tau_{e}}{\tau_{b}}=\frac{2}{\gamma-1}\left[\left(\frac{P_{0}^{\circ}}{P_{c}}\right]^{\frac{\gamma-1}{2 \gamma}}-1\right]
$$

The real utility of this formulation is that the idealized flow will predict the same quantity of vented gas (using this value of the coherence ratio) as the actual flow will vent over the measured entrainment interval. Computed values of the coherence ratio are presented in Table 4.1 and are plotted in Figure 4.2.

\subsection{Transport Fractions}

Comparison of the TCE model with experiment data requires that the mass distribution throughout the containment be specified. Three transport fractions measured in the IET tests are listed in Table 3.3. These transport fractions are also plotted in Figure 4.3. The transport fractions and measured values of the coherence ratios are used in the TCE model calculations.

The first transport fraction $\left(f_{\text {cioud }}\right)$ represents the fraction of melt ejected from the melt generator. Approximately 5-10 percent of the melt was retained as a frozen crust in the SNL/ANL counterpart tests. These experiments employed hemispherical melt generators scaled to the lower head of the Zion RPV so that the melt pool was relatively shallow, and steam blowthrough occurred relatively quickly, before all of the molten debris was out of the melt generator.

The second transport fraction $\left(f_{\text {dupp }}\right)$ represents the fraction of melt injected into the cavity that is subsequently dispersed into the containment. About 75 percent dispersal was observed in the IET tests; the retained melt was a thin frozen crust on all cavity surfaces.

The third transport fraction $\left(f_{\text {dones }}\right)$ represents the fraction of the melt that is dispersed from the cavity that finds its way out of the subcompartment structures and into the dome of the containment. Accurate representation of the major flow paths from the subcompartment to the upper dome in a Zion geometry exists only in the SNL/ ANL counterpart experiments. In these tests, about 10 percent of the dispersed material (10 percent of the initial melt mass) found its way to the dome. The dominant mechanism was inertial transport through openings in the seal table room. Substantially larger transport fractions are reported for a few tests, but these are always associated with tests where substantial damage to the floor and walls of the seal table room was reported (structural strengths were not preserved in the scaled tests). It is worth noting that none of the complicating features, e.g. incore instrument guide tubes and the seal table itself, that might inhibit melt flow into the seal table room were modeled in these experiments. Furthermore, in the Zion NPP personnel access to the cavity is restricted by the "penthouse," which is a steel room with blowout panels located over the cavity exit. Thus, the observed transport fractions are upper bounds to what is expected in the actual plant.

\subsection{Nonreactive Atmosphere}

Pressure predictions of the TCE model are compared to experiment data in two steps: data with nonreactive atmospheres (i.e. no chance of hydrogen combustion) and data where hydrogen 
combustion occurred (or could have occurred). The latter will be preceded by a comparison of hydrogen production predictions with experiment measurements.

Figure 4.4 compares predicted pressure efficiencies with measured efficiencies for those experiments where hydrogen combustion is inerted by excluding oxygen from the atmosphere. The latter is obtained by normalizing the measured pressure rise by the maximum possible pressure rise, as predicted by the single-cell equilibrium model. The TCE model does an excellent job of correlating the data. This has important implications. The Limited Flight Path (LFP) [Allen et al. 1991b] and Corium-Water Interaction (CWTI) [Spencer et al. 1987] tests employed only the crudest representation of containment compartmentalization, while the SNL/ANL IET tests and the FAI/DCH [Henry et al. 1991] tests employed accurate and complex representations of the Zion subcompartment geometry. Yet all the tests apparently are correlated by the TCE model. This suggests that the limited heat sink (coherent blowdown gas and possibly some subcompartment atmosphere) inherent in the TCE model is the dominant mitigating mechanism for debris/gas heat transfer. Since experiments have been conducted at four different scales, the comparisons in Figure 4.4 also suggest that debris/gas heat transfer is insensitive to physical scale.

\subsection{Hydrogen Production}

Hydrogen produced by metal reactions with the coherent part of the blowdown steam is the most important of several possible sources of hydrogen because this is the hydrogen that is heated and dispersed to the dome as a hot jet, which is likely to burn as a diffusion flame. Figure 4.5 compares predicted hydrogen with measured hydrogen for those tests that had no water in the cavity or on the containment basement floor and also had no reactive atmospheres. Model predictions are in good agreement with data, so this important source of hydrogen production is well validated to within the uncertainties in estimating the coherence ratio for the tests.

Figure 4.6 compares model predictions of hydrogen production with experiment data for those tests that had reactive atmospheres, or water in the cavity, or water on the containment floor. Model predictions, based on metal reactions with coherent steam, consistently underpredict the data. The margin between prediction and data can be as large as 150 percent. Four reasons can be cited for the discrepancy:

1. iron/oxygen reactions distort measurements of the amount of hydrogen produced,

2. metal reactions with cavity water produce hydrogen,

3. metal reactions with water on the basement floor produce hydrogen, and

4. noncoherent steam can react with nondispersed metals in the cavity.

In all cases, these phenomena should have no impact on containment pressurization. These possibilities, for the reason that more hydrogen was measured than predicted, require some explanation.

The amount of hydrogen reported as produced during a DCH experiment is inferred from pretest and posttest gas samples of the atmosphere. Moles of hydrogen produced are computed by taking the sum of the final hydrogen inventory and the amount of hydrogen bumed, as inferred by changes in the oxygen inventory, and subtracting the amount of hydrogen preexisting in the atmosphere. It is assumed that the amount of hydrogen burned can be calculated based on oxygen depletion from the stoichiometric reaction of hydrogen with oxygen to form water. This assumption can distort reported hydrogen production numbers because unreacted metals (mostly iron) can react directly with oxygen over a prolonged time period. These unreacted metals 
are splattered over subcompartment structures and some are transported to the dome. These reactions produce no hydrogen and occur over such a protracted time frame that any oxidation energy cannot possibly contribute to peak pressurization.

Most gas samples were taken at relatively long times (2 - $30 \mathrm{~min}$ ) in the SNL/ANL IET tests. Early gas samples were taken in the ANL/IET-8 experiment $(\approx 30$ s) and the SNL/IET-8B experiment $(\approx 15 \mathrm{~s})$ when this possibility was suspected. These sampling times are well beyond the period of peak pressurization $(\approx 3 \mathrm{~s})$ in these experiments. Table 4.2 summarizes changes as a function of sampling time. Clearly, large changes in reported hydrogen measurements (produced and burned) can be attributed to protracted changes in the oxygen inventory, and this has no impact on containment pressurization.

The changes in oxygen inventory could, of course, be associated with a slow reaction of hydrogen. If so, the time scale is too long to contribute to peak containment pressurization. Pressure predictions for SNL/ANL experiments with hydrogen combustion are about one bar higher than measurements when the predictions are based on the reported amount of hydrogen burned. Thus, the predicted contribution to pressurization associated with hydrogen combustion is about twice what is actually observed in the experiments. Either way, protracted metal/oxygen reactions or slow burning of hydrogen, these processes do not contribute to peak DCH loads.

Melt first entering the cavity as a single-phase jet can react with cavity water if present. As discussed previously, these interactions tend to involve only a small fraction of the melt and blow most of the water from the cavity. The WC-1,2 [Allen et al. 1992a] tests are comparable (nonreacting atmospheres) where WC-1 had a dry cavity and WC-2 was about 10 percent filled with water. The wet cavity test produced about 25 percent more hydrogen than the dry test, but some of this additional hydrogen could have been produced after the dispersed metal and cavity water settled to the containment floor. Hydrogen produced during the initial thermite/water interaction will precede the hot debris/gas plume (initiated with blowdown) into the subcompartment and will be pushed to the dome as a cold jet that is not likely to burn.

Dispersed metals can also react with either preexisting water on the basement floor or water displaced from the cavity that settles to the floor. Substantial hydrogen production from reactions on the basement floor have been observed in the FAI/DCH [Henry et al. 1991] tests that employed nonreactive blowdown gases and nonreacting containment atmospheres. These reactions produced quantities of hydrogen comparable to what is predicted from metal reactions with coherent blowdown steam. Likewise, the SNL/IET-3,4 [Allen et al. 1992c,d] tests had similar initial conditions, but 33\% more hydrogen was produced in IET-4, which had water on the containment basement floor. A commensurate increase in containment pressurization was not observed in the wet test because the additional hydrogen, likely produced over an extended period of time, did not burn or bumed too slowly to be effective. Spencer [1987] dropped hot metal-bearing melts into water and measured significant production of hydrogen, but over a time frame too long to be of interest when calculating DCH loads.

Lastly, hydrogen might be produced from the reaction of nondispersed metals with the noncoherent "tail" of the blowdown gas. This process will produce hydrogen that is sourced into a subcompartment void of oxygen. Some of this hydrogen may be transported to the containment dome, but it will be too cool to burn as a diffusion flame.

In summary, there are several sources of hydrogen in a DCH event, but hydrogen produced from reactions of dispersed melt with coherent steam are the most important in terms of 
Interpretation of Results

hydrogen combustion on a time scale that can contribute to peak containment pressurization.

\subsection{Hydrogen Combustion}

This hot hydrogen enters the upper dome where, in general, it is expected to burn as a diffusion flame, subject to possible inerting as suggested by Williams [1992]. Table 4.3 compares the Williams' criterion with observed jet behavior. Detection of jet combustion is based on visual observations and measured containment pressurization. Inferring jet combustion from changes in the oxygen inventory is ambiguous for the reasons discussed previously. Table 4.2 shows that hydrogen combustion is predicted in all cases except for SNL/IET-5 where both prediction and observation indicate that the jet should not and did not burn.

The only violation of experiment observation is ANL/IET-8 where combustion would have been expected based on the Williams' criterion. More restrictive criteria, based on a competition between the kinetics of chemical and hydrodynamic processes, are likely to be scale dependent with the threshold for sustained combustion being broader at larger scale. The ANL/IET-8 experiment is noteworthy in that it is the only test conducted to date that had an air/ steam/hydrogen atmosphere. It has been suggested that steam has an added inerting effect not accounted for by a reduction in oxygen. This perspective will be clarified by $1 / 6^{\text {th }}$ scale tests that will be conducted at SNL with steam in the atmosphere. For now, it is sufficient to note that the Williams' criterion is conservative, predicting combustion where it was not observed.

Autoignition and volumetric combustion of preexisting hydrogen is the last mode of hydrogen combustion requiring validation. Table 4.4 compares peak temperatures in the dome (estimated from peak pressures in the dome) with predicted autoignition temperatures. In all cases, autoignition was neither predicted to occur, nor was it observed. Validation is, of course, required for cases where autoignition might be expected to occur. The $1 / 6^{\text {t }}$ scale test to be conducted at SNL will serve this purpose. Failure to observe autoignition where it is predicted can only render the current model more conservative.

\subsection{Integral Validation}

Hydrogen production and combustion thresholds have been validated by parts. It remains to validate integral predictions of those tests conducted with reactive atmospheres. Predictions are compared to experiment data in Figure 4.7. The scatter is only slightly worse than the cases with nonreactive atmospheres. This integral agreement supports the assumption that only hydrogen produced from coherent steam will burn.

Agreement is good in all cases except ANL/ IET-8, which was a relatively benign test in which neither jet combustion nor autoignition was observed. The models, however, predicted that the jet would bum, creating dome temperatures exceeding the autoignition threshold leading to volumetric combustion of all preexisting hydrogen; hence, the very high predicted pressure efficiencies for this test.

Lastly, Figure 4.8 compares predictions with all data from experiments in compartmentalized geometry. The agreement is remarkable given that tests have been performed at $1 / 10^{\infty}, 1 / 20^{\circ}$, $1 / 30^{\mathrm{t}}$, and $1 / 40^{\mathrm{t}}$ physical scale, with only threshold phenomena potentially affected by physical scale. Containment loads are also insensitive to details of subcompartment geometry. 
Table 4.1 Computed values of the coherence ratio

\begin{tabular}{cccc}
\hline TeAt & $\tau_{0}^{\prime}$ & $P^{\circ}$ & $\tau^{\prime} / \tau_{b}$ \\
\hline SNL/IET-1 & 0.95 & 1.58 & 0.35 \\
SNL/IET-1R & 1.05 & 1.55 & 0.34 \\
SNL/IET-3 & 0.90 & 1.49 & 0.31 \\
SNL/IET-4 & 0.85 & 1.46 & 0.29 \\
SNL/IET-5 & 1.00 & 1.59 & 0.35 \\
SNL/IET-6 & 0.90 & 1.50 & 0.31 \\
SNL/IET-7 & 1.20 & 1.89 & 0.50 \\
SNL/IET-8B & 1.20 & 1.58 & 0.35 \\
\hline
\end{tabular}

Table 4.2 Time variations of reported hydrogen measurements

\begin{tabular}{|c|c|c|c|}
\hline ? & & $\begin{array}{c}\text { ANL/IET-8 } \\
(g \cdot \text { moles })\end{array}$ & $\begin{array}{c}\text { SNL/IET-8B } \\
(g \cdot \text { moles })\end{array}$ \\
\hline$\approx 15$ - 30 s sample & $\begin{array}{c}\Delta \mathbf{N}_{\text {O2 }} \\
\mathbf{N}_{\text {H2(PROD) }} \\
\mathbf{N}_{\text {H2(BURNED) }}\end{array}$ & $\begin{array}{l}0.1 \\
1.6 \\
0.2\end{array}$ & $\begin{array}{l}100 \\
247 \\
201\end{array}$ \\
\hline$\approx 2 \mathrm{~min}$ sample & $\begin{array}{c}\Delta \mathbf{N}_{O 2} \\
\mathbf{N}_{\text {HR(PROD) }} \\
\mathbf{N}_{\text {R2(BURNED) }}\end{array}$ & $\begin{array}{l}0.5 \\
4.6 \\
1.0\end{array}$ & $\begin{array}{l}119 \\
283 \\
228\end{array}$ \\
\hline$=30 \mathrm{~min}$ sample & $\begin{array}{c}\Delta \mathbf{N}_{02} \\
\mathbf{N}_{\text {HR(PROD) }} \\
\mathbf{N}_{\text {HZ(BURNED) }}\end{array}$ & & $\begin{array}{l}140 \\
299 \\
281\end{array}$ \\
\hline
\end{tabular}


Table 4.3 Inerting criteria for jet combustion

\begin{tabular}{ccccc}
\hline Test & $\left(\mathbf{X}_{02}\right)_{\text {Mes }}$ & $\begin{array}{c}\text { Jet combustion } \\
\text { observed }\end{array}$ & $\left(\mathbf{X}_{02}\right)_{\mathrm{cer}}$ & $\begin{array}{c}\text { Jet combustion } \\
\text { predicted }\end{array}$ \\
\hline SNL/IET-3 & 0.090 & yes & 0.047 & yes \\
SNL/IET-4 & 0.095 & yes & 0.047 & yes \\
SNL/IET-5 & 0.044 & no & 0.060 & no \\
SNL/IET-6 & 0.098 & yes & 0.046 & yes \\
SNL/IET-7 & 0.096 & yes & 0.046 & yes \\
SNL/IET-8B & 0.102 & yes & 0.046 & yes \\
ANL/IET-3 & 0.108 & yes & 0.045 & yes \\
ANL/IET-6 & 0.099 & yes & 0.045 & yes \\
ANL/IET-7 & 0.108 & yes & 0.046 & yes \\
ANL/IET-8 & 0.077 & no & 0.040 & yes \\
\hline
\end{tabular}

Table 4.4 Validation of autoignition criteria for volumetric combustion

\begin{tabular}{lccc}
\hline \multicolumn{1}{c}{ Test } & $\mathbf{X}_{\mathrm{m2}}$ & $\begin{array}{c}\text { Dome temp. (K) } \\
\text { max. meas. }\end{array}$ & Predicted autoignition temp. (K) \\
\hline SNL/IET-5 & 0.028 & 442 & 856 \\
SNL/IET-6 & 0.026 & 742 & 867 \\
SNL/IET-7 & 0.040 & 712 & 866 \\
SNL/IET-8B & 0.038 & 668 & 857 \\
ANL/IET-6 & 0.020 & 716 & 903 \\
ANL/IET-8 & 0.039 & 794 & 921 \\
\hline
\end{tabular}




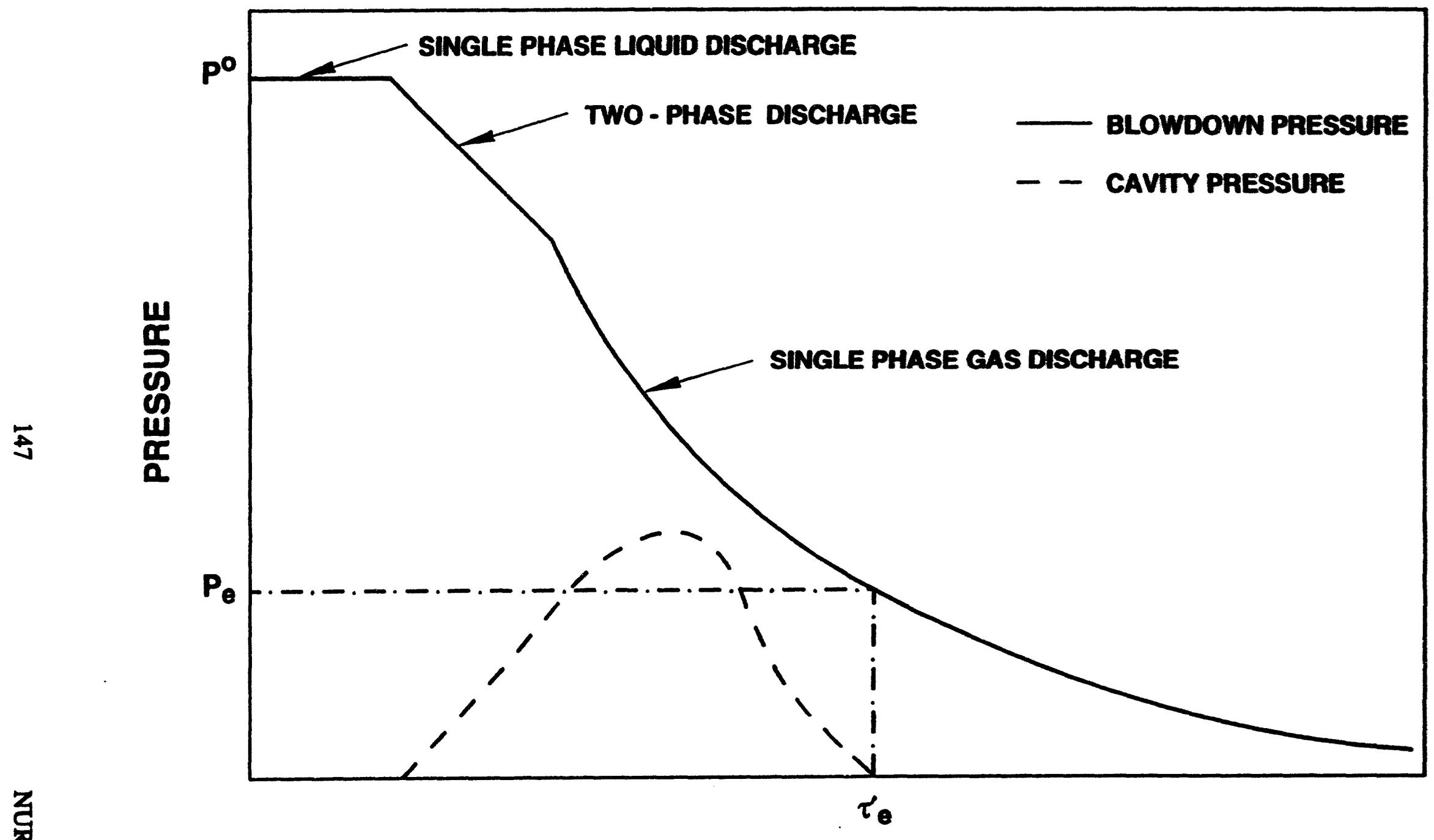

TIME

Figure 4.1 Idealized blowdown curve and cavity pressure curve illustrating the methed used to determine the coberence ratio 


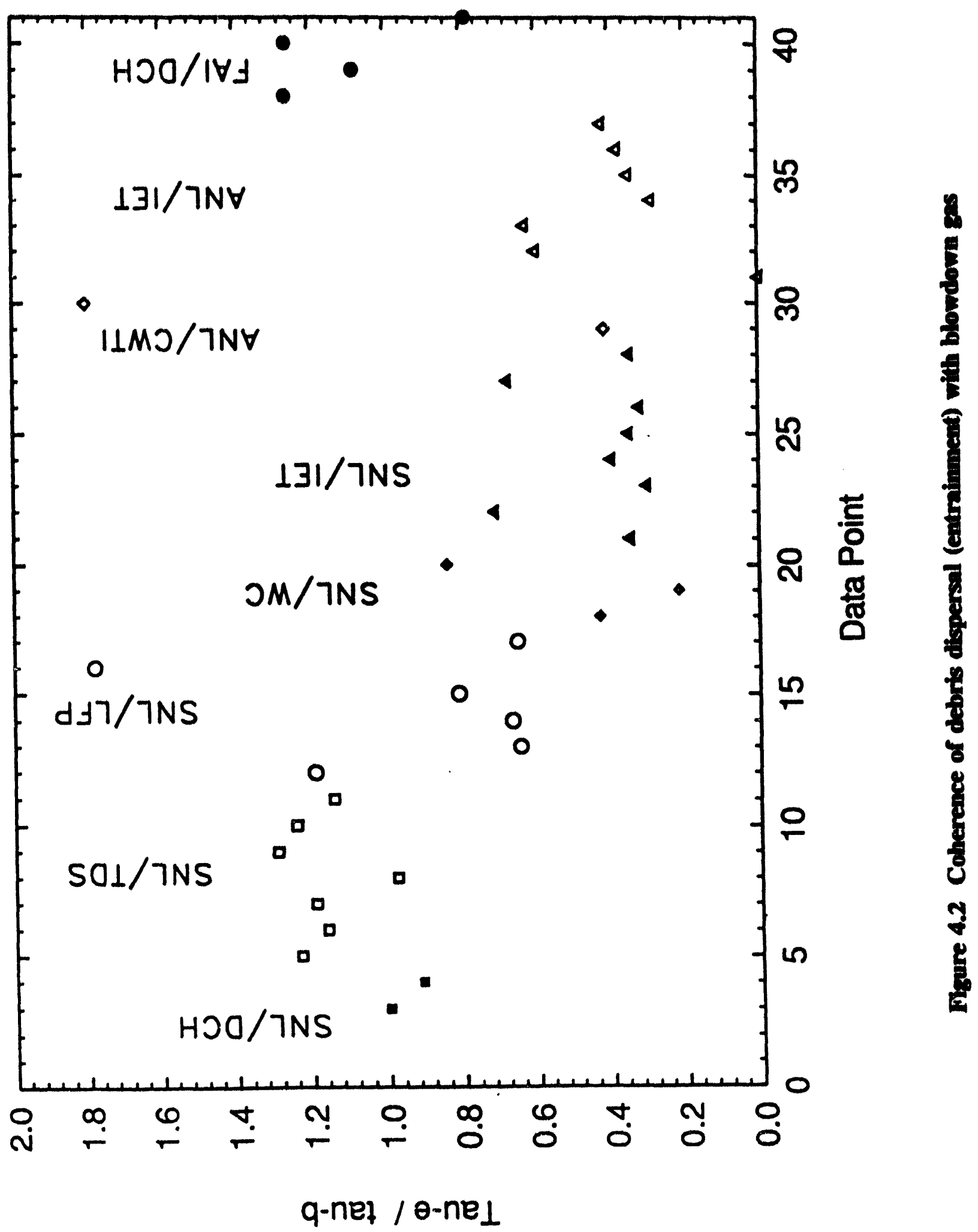


Interpretation of Results
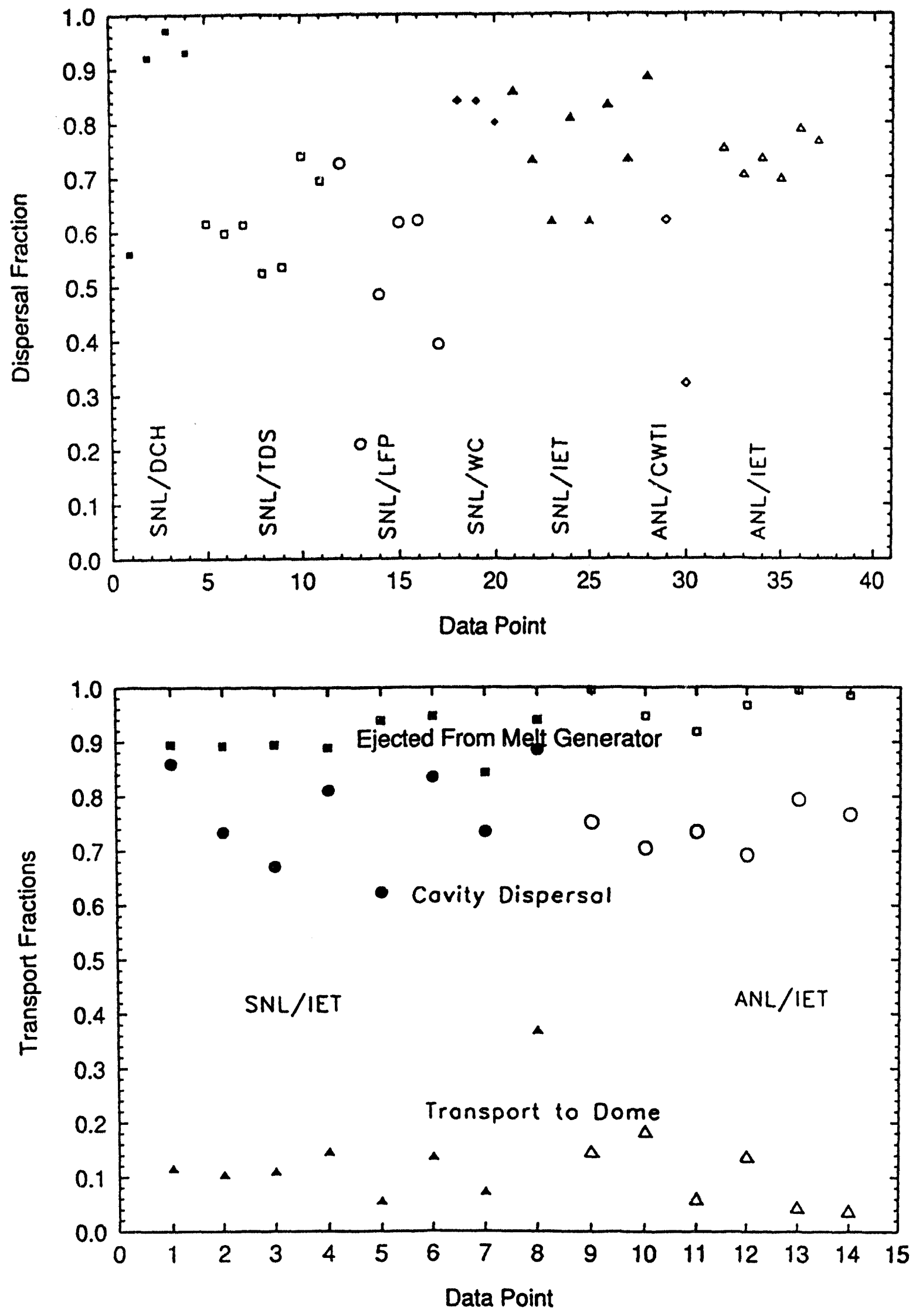

Figure 4.3 Distribution of melt mass in the Zion geometry 


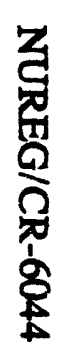

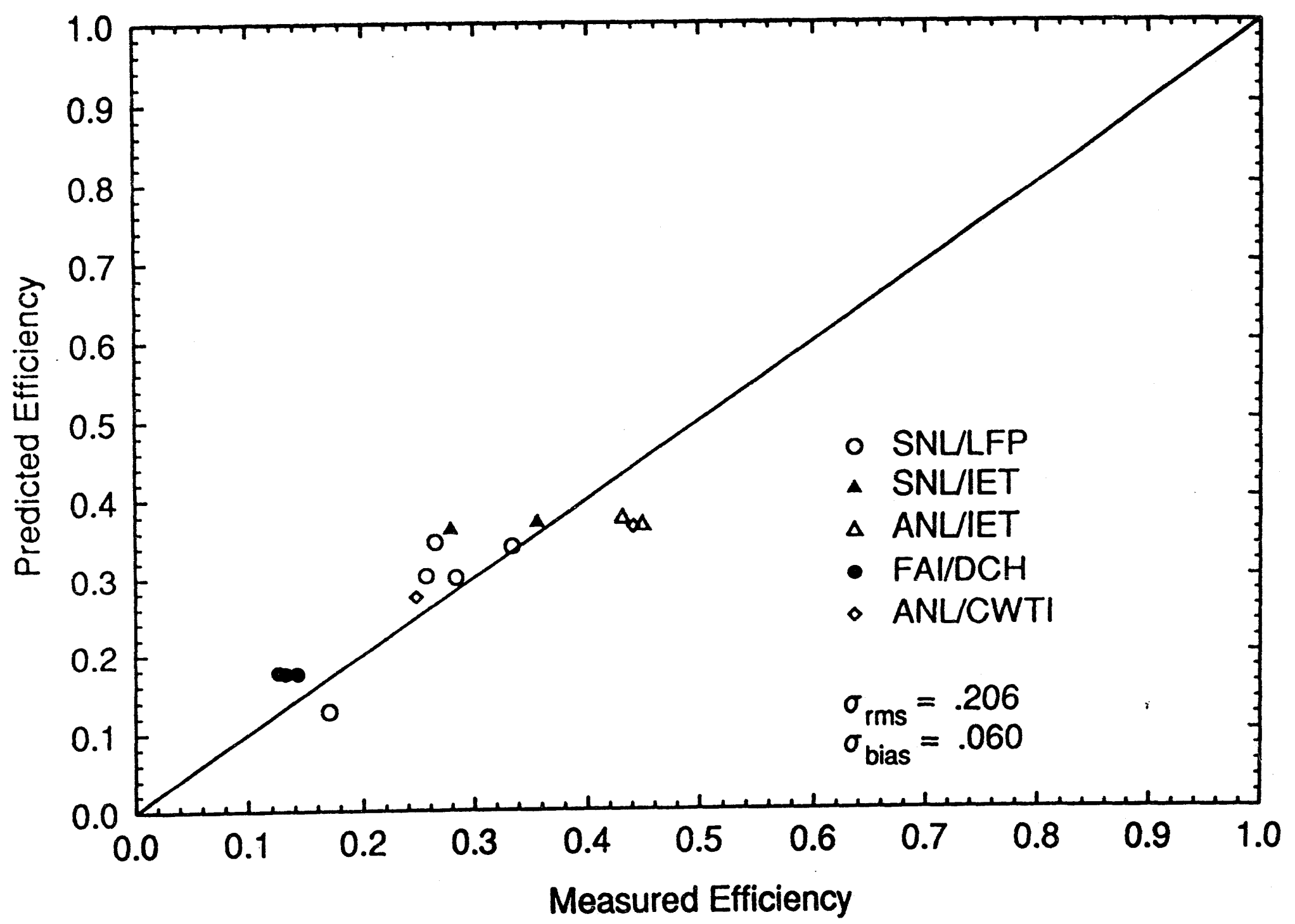

Figure 4.4 Validation of the TCE model with experiments where the atmosphere was inert 


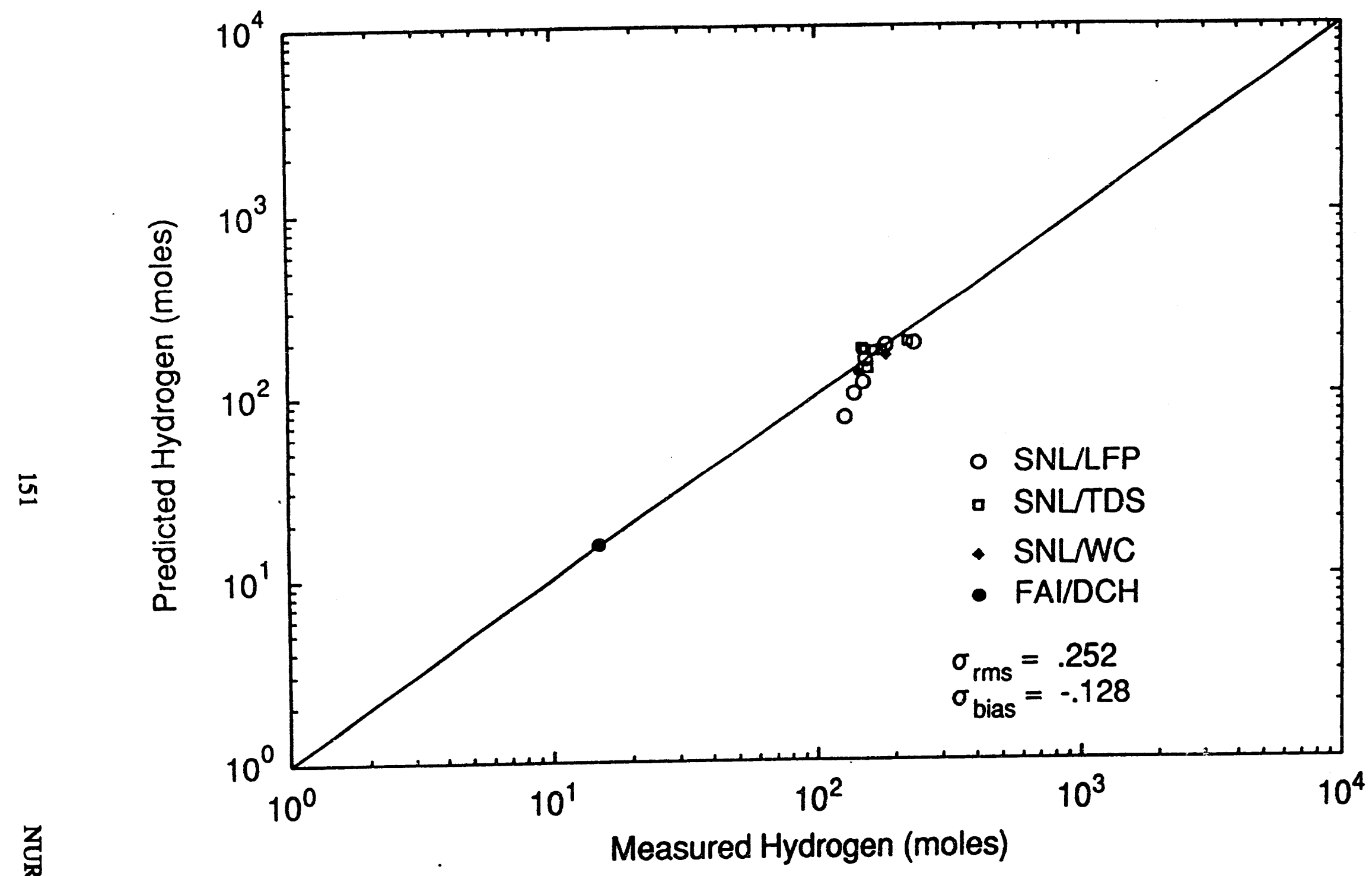

Figure 4.5 Validation of hydrogen production predictions (no cavity/containment water and nonreactive atmospheres) 


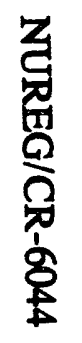

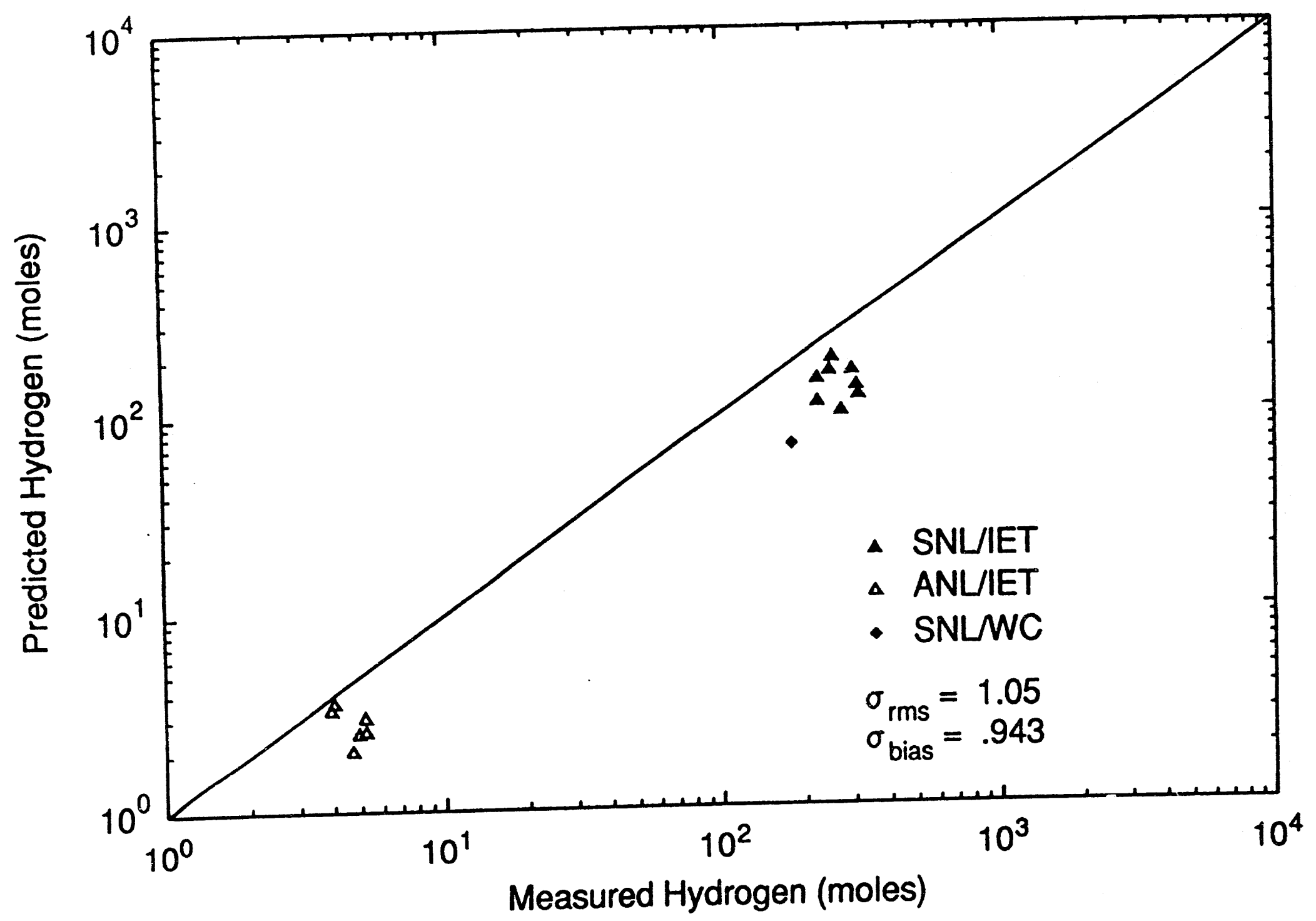

$\triangle$ ANL/IET

- SNLNC

Figure 4.6 Comparison of hydrogen production predictions with experiment data (water in cavity and/or containment and/or reactive atmospheres) 


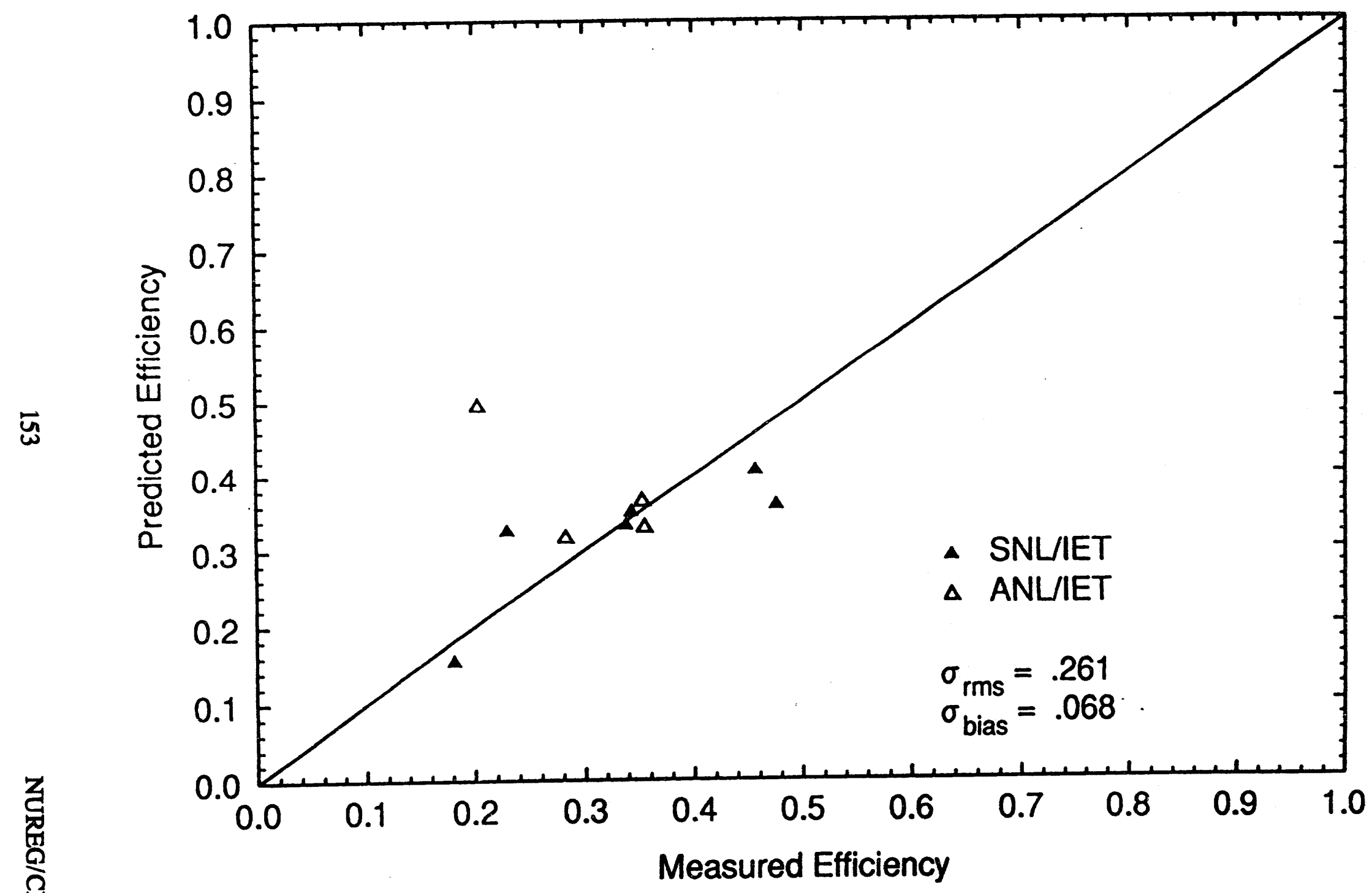

Figure 4.7 Validation of the TCE model with experiments where hydrogen could burn in a reactive atmosphere 


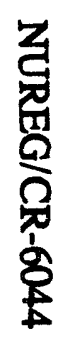

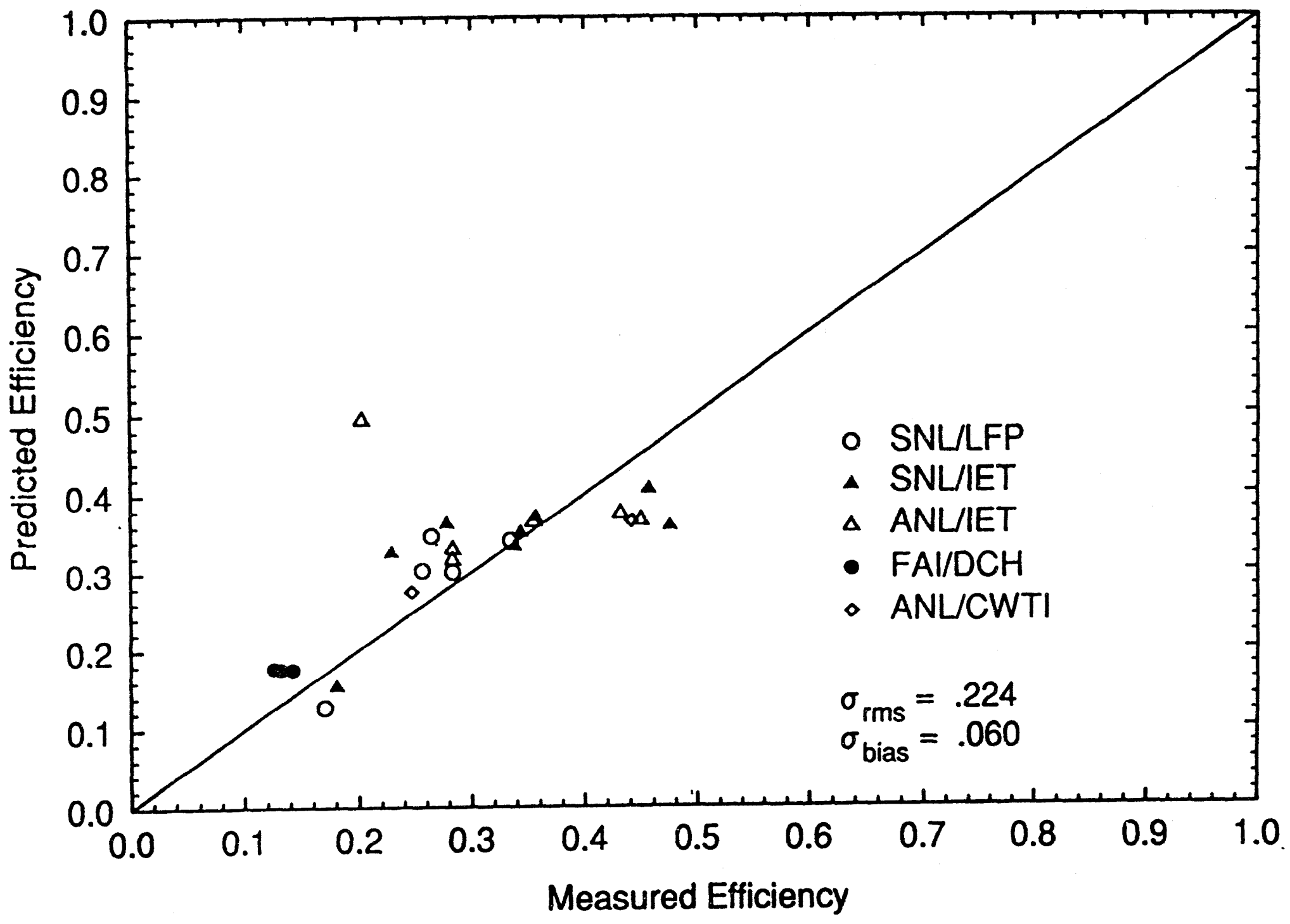

Figure 4.8 Validation of the TCE model against all experiments with compartmentalized geometry 


\subsection{Hydrogen Flammability}

An important issue in HPME sequences is the contribution of hydrogen combustion to the peak containment pressure. Hydrogen that is produced by steam/metal reactions in the cavity and subcompartments, along with any preexisting hydrogen in the containment atmosphere, may recombine with oxygen in the subcompartments or upper dome. Hydrogen combustion will release energy to the atmosphere and could significantly increase the loads on the containment building.

The initial atmospheric conditions in the IET experiments were outside of the envelope of flammable concentrations shown in Figure 5.1, a hydrogen/oxygen/nitrogen flammability curve [Kumar 1985]. Individual ignition sources, e.g. molten debris particles, should not have resulted in significant volumetric combustion of preexisting hydrogen, or even in any propagating flames in the IET experiments. Therefore, vigorous combustion of preexisting hydrogen in the IET experiments was not expected. The 2-minute and 30-minute gas grab samples in IET- 6 and IET-7 indicated that a small amount of preexisting hydrogen had burned; however, this burning probably occurred in localized areas as molten particles mixed throughout the Surtsey vessel. The combustion of any preexisting hydrogen probably happened over a time frame that was long in comparison to the time at which the peak pressure occurred.

Although global combustion of preexisting hydrogen was unlikely under the conditions in the IET experiments, hydrogen produced by steam/metal reactions during the HPME apparently burned as it exited the subcompartments and entered the upper dome atmosphere. Videos taken during the experiments showed bright orange flames, and the thermocouples indicated burning jets over the openings in the operating deck floor. Clearly, the experimental results indicate that hydrogen produced by steam/metal reactions during the HPME bumed as it entered the upper dome and made a significant. contribution to the peak pressure; however, significant combustion of preexisting hydrogen did not occur, and any that did occur, did so on a time frame that was long compared to the time of the peak containment pressure and thus had an insignificant impact on the peak containment pressure. 


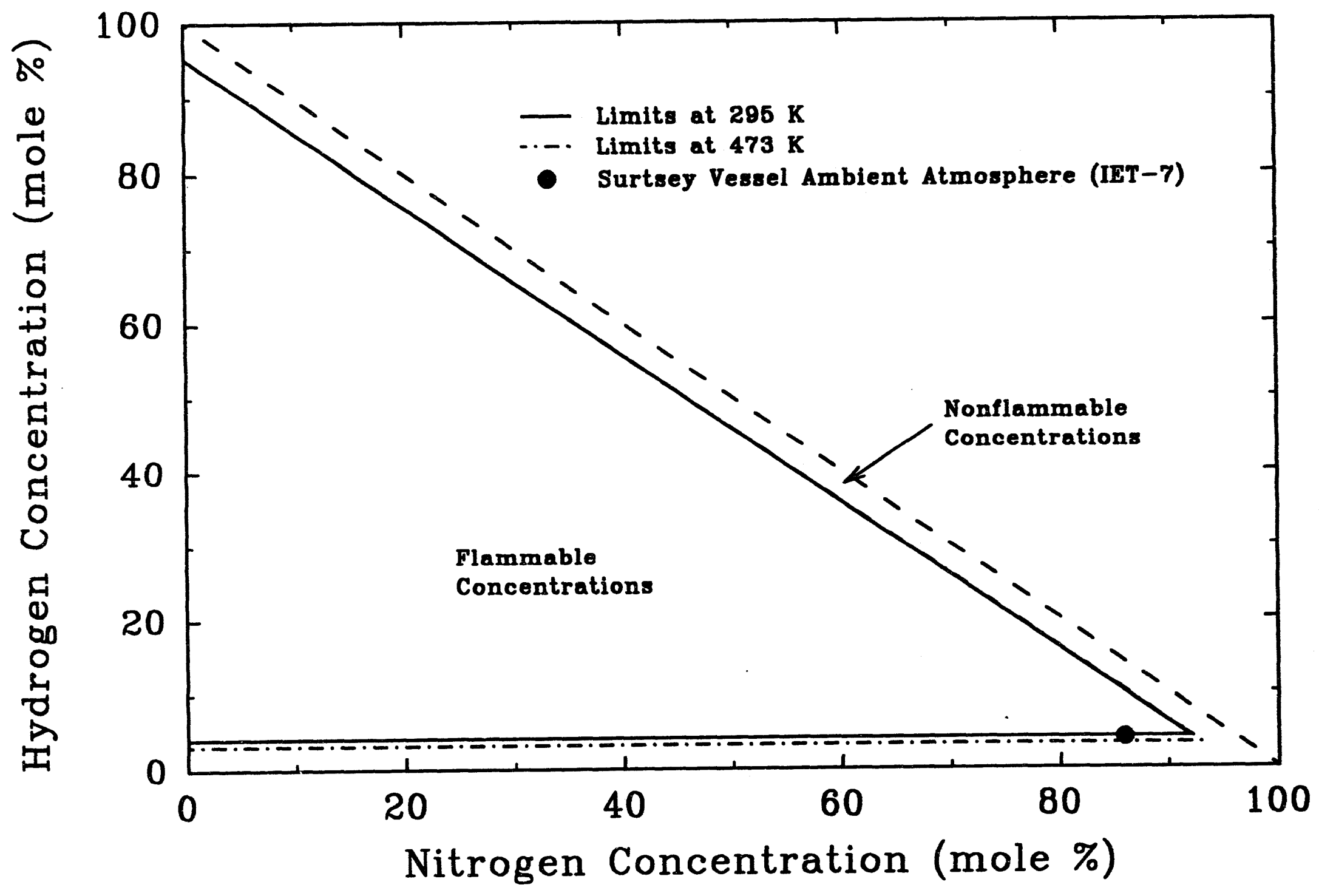

Figure 6.1 Upward propagation limit for hydrogen/oxjgen/nitrogen mixtures 


\subsection{Summary}

The Integral Effects Test (IET) series was conducted in the Surtsey vessel to investigate several unresolved DCH phenomenological issues: (1) the effect of physical scale, (2) the effect of prototypic subcompartment structures, (3) the effect of water in the cavity and on the containment basement floor, and (4) the effect of hydrogen combustion on containment loads. A summary of the results of the IET tests is presented in Table 6.1.

The IET experiments were conducted using 1:10 linear scale models of the Zion NPP structures. There were twelve experiments in the IET test series: IET-1, IET-1R, IET-2A, IET-2B, IET-2C, IET-3, IET-4, IET-5, IET-6, IET-7, IET-8A, and IET-8B. In the IET-2A, 2B, and $2 C$ experiments, the Surtsey vessel was not used; the melt generator was attached to a nondispersive cavity. These tests were conducted specifically to determine the temperature of debris ejected from the scaled RPV model into the reactor cavity. The other experiments used models of the Zion structures inside the Surtsey vessel. The initial conditions of the Surtsey atmosphere during the IET series can be grouped into three classes: (1) inert (IET-1 and IET-1R) or classically inert (IET-5), (2) reactive, i.e., containing $0.1 \mathrm{MPa}$ of air and $0.1 \mathrm{MPa}$ of nitrogen, which was used as a surrogate for steam (IET-3 and IET-4), and (3) reactive plus preexisting hydrogen (IET-5, IET-6, IET-7, IET-8A, and IET-8B). In the inert tests, hydirogen was produced by debris oxidation but did not burn due to lack of oxygen. The classically inert test used carbon dioxide as a surrogate for steam. The carbon dioxide effectively inerted the combustion of preexisting hydrogen and inerted the combustion of most of the hydrogen produced by debris oxidation. Tests with air/nitrogen and air/nitrogen plus preexisting hydrogen atmospheres indicated that a jet of hydrogen produced by steam or water reactions with metallic debris burned as it entered the vessel. Combustion of this hydrogen contributed significantly to the containment load.
Some preexisting hydrogen burned, but did not burn on a time scale that had a significant impact on the peak vessel pressure.

The results of IET-8A indicate that the thermite/water interactions from a gravity pour into a half-filled cavity produced cavity pressures of $\approx 3.7 \mathrm{MPa}$ and Surtsey upper dome pressures of $0.087 \mathrm{MPa}$. Though these cavity pressures may fail some cavities, they do not appear to be large enough to cause missile concerns. Most of the debris remained on the floor of the cavity. In addition, with initial atmospheric hydrogen concentrations of $4.3 \mathrm{~mol} . \% \mathrm{H}_{2}$, the thermite/water interaction did not cause a global hydrogen burn and significant upper dome pressures. Most of the vessel pressure was probably the result of vaporization of cavity water and some combustion of the hydrogen produced during the HPME event. This result is of interest because of current schemes to mitigate DCH through depressurizing the RPV and flooding the cavity with water.

In the IET-8B experiment, high-pressure steam at $\approx 6.3 \mathrm{MPa}$ was used to eject an initial charge of $43 \mathrm{~kg}$ of molten thermite into Surtsey. Multiple, energetic thermite/water interactions occurred when the melt contacted the cavity water, though there were no large steam explosions. In IET-8B large amounts of cavity water produced two competing effects on vessel pressure. Gas temperatures were dramatically reduced because energy was taken from the debris as it vaporized cavity and subcompartment water; this effect should have reduced the peak vessel pressure. However, vaporization of the water added moies of steam to the Surtsey vessel and thus should have produced a significant increase in pressure. These two effects appeared to counteract each other and resulted in a peak pressure similar to those observed in previous experiments with similar initial conditions but with much less water in the cavity. The conclusion is that cavity water did not have a significant effect on the containment load under these conditions. 
Major conclusions of the Zion IET experiments are summarized below.

1. The iron/alumina/chromium melt ejected from the melt generator into the cavity had a temperature of $2550 \pm 100 \mathrm{~K}$. This temperature is in the expected range of melt temperatures associated with core melt accidents leading to vessel breach.

2. Debris ejection into condensate levels of water in the cavity model showed two distinctly different responses: (1) a very sharp pressure spike, indicating an energetic thermite/water interaction, i.e., steam explosion (e.g., in IET-1 and IET-6); and (2) a broad pressure transient, indicating rapid vaporization of cavity water (e.g., in IET-1R and IET-3). It is unclear if these different responses are due to the stochastic nature of the phenomena, or are due to variables that are not presently recognized as important.

3. Approximately $90 \% \pm 5 \%$ of the melt in the scale model of the RPV bottom head was expelled into the cavity by $6.3 \mathrm{MPa}$ steam under the conditions used in these tests.

4. Approximately $77 \% \pm 10 \%$ of the melt in the reactor cavity was dispersed into the Surtsey vessel under the conditions used in these tests.

5. Approximately $9.3 \% \pm 2.6 \%$ of the melt dispersed into the Surtsey vessel was found outside the subcompartment structures in the tests that did not experience significant structural damage, i.e., IET-1, IET-1R, IET-3, IET-5, and IET-7.

6. Water on the containment basement floor did not appear to have a significant effect on the peak containment load.
7. There are two sources of potentially combustible hydrogen in a DCH event: (1) hydrogen produced during the HPME event by steam or water reactions with metallic debris; and (2) preexisting hydrogen released from the reactor coolant system prior to vessel failure. In the IET experiments with reactive atmospheres, the hydrogen produced during the HPME bumed efficiently as gas was pushed out of the subcompartments into the upper dome. This hydrogen combustion contributed significantly to containment pressurization, i.e., peak pressure increases were about $100 \mathrm{kPa}$ for tests with inert atmospheres (IET-1, IET-1R, and 5) and were about $250 \mathrm{kPa}$ for tests with reactive atmospheres (IET-3, 4, 6, and 7). Some preexisting hydrogen bumed, but did not burm on a time scale that had a significant impact on the peak vessel pressure.

8. All of the IET data and previous DCH experiments were analyzed with the TCE model so that conclusions could be drawn about DCH phenomena under a variety of initial conditions. All of the DCH experiments conducted to date are predicted reasonably well by the TCE model. This suggests that the limited heat sink (coherent blowdown gas and possibly some subcompartment atmosphere) is the dominant mitigating mechanism for debris/gas heat transfer.

9. Since the TCE model produced reasonable predictions for DCH experiments at four different physical scales, the results indicate that debris/gas heat transfer is insensitive to physical scale.

10. Since experiments that make up the DCH database have been conducted with different subcompartment configurations, the fact that the TCE model correlates the data reasonably well suggests that debris/gas heat transfer is insensitive to the details of subcompartment geometries. 
Table C.1 Summary of the results of the IET experiments

\begin{tabular}{|c|c|c|c|c|c|c|c|c|c|}
\hline (2) & ET-1 & IET-1R & IET-3 & IET-4 & IET-5 & IET-6 & IET-7 & IIT-8A & IET-8B \\
\hline $\begin{array}{l}\text { Moles of } \mathrm{H}_{2} \mathrm{O} \text { driving gas } \\
(\mathrm{g} \cdot \text { moles })\end{array}$ & 468 & 507 & 485 & 582 & 453 & 505 & 416 & $\begin{array}{l}4.1 \\
\left(\mathrm{~N}_{2}\right)\end{array}$ & 545 \\
\hline Cavity water $(\mathrm{g} \cdot \mathrm{moles})$ & 193 & 193 & 193 & 193 & 193 & 193 & 193 & 3444 & 3444 \\
\hline Basement water $(\mathrm{g} \cdot$ moles $)$ & 0 & 0 & 0 & 3950 & 3950 & i & 3950 & 3950 & 3950 \\
\hline Ablated hole diameter $(\mathrm{cm})$ & 4.04 & 4.02 & 4.53 & 4.22 & 4.31 & 3.91 & 4.08 & 3.50 & 4.10 \\
\hline $\begin{array}{l}\text { Total debris dispersed into } \\
\text { Surtsey }(\mathrm{kg})\end{array}$ & 43.0 & 36.2 & 34.3 & 40.7 & 33.1 & 42.5 & 36.7 & 8.6 & 42.9 \\
\hline \multicolumn{10}{|l|}{ Oxygen $(g \cdot$ moles $)$} \\
\hline - Pretest & 2 & 15 & 656 & 702 & 318 & 681 & 683 & 700 & 700 \\
\hline \multicolumn{10}{|l|}{ Hydrogen $(\mathrm{g} \cdot \mathrm{moles})$} \\
\hline $\begin{array}{l}\text { - Pretest } \\
\text { (mol. \%) }\end{array}$ & 0 & 0 & 0 & $\mathbf{0}$ & $\begin{array}{l}202 \\
2.76\end{array}$ & $\begin{array}{r}180 \\
2.59\end{array}$ & $\begin{array}{l}283 \\
3.97\end{array}$ & $\begin{array}{l}308 \\
4.33\end{array}$ & $\begin{array}{l}288 \\
3.91\end{array}$ \\
\hline - Produced (30 min) & 233 & 248 & 227 & 303 & 319 & 319 & 274 & 176 & 299 \\
\hline - Burned (30 min) & 3 & 11 & 190 & 240 & 53 & 345 & 323 & 154 & 281 \\
\hline - Posttest (30 min) & 230 & 238 & 37 & 63 & 468 & 154 & 234 & 330 & 306 \\
\hline$\triangle P$ due to the HPME (kPa) & 98 & 110 & 246 & 262 & 103 & 279 & 271 & 87 & 244 \\
\hline Time to peak pressure (s) & 2.2 & 2.9 & 2.5 & 2.5 & 3.3 & 2.2 & 2.7 & 7.1 & 2.6 \\
\hline
\end{tabular}




\subsection{References}

Allen, M. D., M. Pilch, R. T. Nichols, J. E. Brockmann, D. W. Sweet and W. W. Tarbell, Aug. 1991a, Experimental Results of Direct Containment Heating by High-Pressure Melt Eiection inte the Surtey Yercel: The DCH-3 and DCH-4 Tests, SAND90-2138, Sandia National Laboratories, Albuquerque, NM.

Allen, M. D., M. Pilch, R. T. Nichols and R. O. Griffith, Oct. 1991b, Experiments to Investipate the Effect of Elight. Path on Direct Containment Heatine (DCH) in the Surtery Test Eacility - The Limited Elight Path (LEP Exporiments, NUREG/CR-5728, SAND91-1105, Sandia National Laboratories, Albuquerque, NM.

Allen, M. D., M. Pilch, R. O. Griffith and R. T. Nichols, Mar. 1992a, Experiments to Investigate the Effect of Water in the Cavity on Direct Containment Heating (DCH) in the Surteey Test Eacility - The WC-1 and WC-2 Tests, SAND91-1173, Sandia National Laboratories, Albuquerque, NM.

Allen, M. D., M. Pilch, R. O. Griffith and R. T. Nichols, Mar. 1992b, Experimental Results of Tests to Investigate the Effects of Hole Diameter Resulting from Bottom Head Failure on Direct Containment Heating (DCF) in the Surtsey Test Facility - The WC-1 and WC-3 Tests, SAND91-2153, Sandia National Laboratories, Albuquerque, NM.

Allen, M. D., M. Pilch, R. O. Griffith, D. C. Williams and R. T. Nichols, Mar. 1992c, The Third Integral Effects Test (IET-3) in the Surtsey Test Facility, SAND92-0166, Sandia National Laboratories, Albuquerque, NM.
Allen, M. D., T. K. Blanchat, M. Pilch and R. T. Nichols, Sept. 1992d, The Bffects of Condensate Levele of Water on Direct Containment Heatine (DCH) in Zion-Like Geometry: The Eourth Integral Bffects Test (IET-4) Conducted in the Surtery Test Facility, SAND92-1241, Sandia National Laboratories, Albuquerque, NM.

Allen, M. D., M. Pilch, R. O. Griffith, R. T. Nichols and T. K. Blanchat, July 1992e, Experiments to Invertipate the Bffects of 1:10 Scale Zion Structures on Direct Containment Heating (DCH) in the Surtsey Test Facility: The IET-1 and IET-1R Tests, SAND92-0255, Sandia National Laboratories, Albuquerque, NM.

Allen, M. D., T. K. Blanchat, M. Pilch and R. T. Nichols, Nov. 1992f, Experimental Results of an Integral Effects Test in a Zion-Like Geometry to Investieate the Effects of a Classically Inert Atmosphere on Direct Containment Heating: The IET-5 Experiment, SAND92-1623, Sandia National Laboratories, Albuquerque, NM.

Allen, M. D., T. K. Blanchat, M. Pilch and R. T. Nichols, Dec. $1992 \mathrm{~g}$, An Integral Bffects Test in a Zion-Like Geometry to Investipate the Effects of Preexisting Hydrogen on Direct Containment Heating in the Surtsey test Facility: The IET-6 Experiment, SAND92-1802, Sandia National Laboratories, Albuquerque, NM.

Allen, M. D., T. K. Blanchat, M. Pilch and R. T. Nichols, Dec. 1992h, An Interral Effects Test to Investigate the Effects of Condensate Levels of Water and Preexisting Hydrogen on Direct Containment Heating in the Surtsey Test Facility: The IET-7_Experiment, SAND92-2021, Sandia National Laboratories, Albuquerque, NM. 
Allen, M. D., T. K. Blanchat, M. Pilch and R. T. Nichols, Feb. 1993, Experiments to Investicate the Effects of Fuel/Coolant Interactions on Direct Containment Heatine - The IET-8A and IET-8B Experiments, SAND922849, Sandia National Laboratories, Albuquerque, NM.

Binder, J. L., L. M. McUmber and B. W. Spencer, May 1992a, Ouick Look Data Report on the Integral Effects Test $1 R$ in the Corexit Eacility at Aroonne National Laboratory, Argonne National Laboratory, Argonne, II.

Binder, J. L., L. M. McUmber and B. W. Spencer, May 1992b, Ouick Look Data Report on the Integral Effects Test. 1RR in the Corexit Eacility at Argonne National Laboratory, Argonne National Laboratory, Argonne, II.

Binder, J. L., L. M. McUmber and B. W. spencer, July 1992c, Quick Look Data Report on the Integral Effects Test-3 in the Corexit Facility at Argonne National Laboratory, Argonne National Laboratory, Argonne, II.

Binder, J. L., L. M. McUmber and B. W. Spencer, Aug. 1992d, Quick Look Data Report on the Integral Effects Test-6 in the Corexit Facility at Arronne National Laboratory, Argonne National Laboratory, Argonne, II.

Binder, J. L., L. M. McUmber and B. W. Spencer, Sept. 1992e, Quick Look Data Report on the Integral Effects Test-7 in the Corexit Eacility at Arronne National Laboratory, Argonne National Laboratory, Argonne, IL.

Binder, J. L., L. M. McUmber and B. W. Spencer, Oct. 1992f, Ouick Look Data Report on the Integral Effects Test-8 in the Corexit Facility at Argonne National Laboratory, Argonne National Laboratory, Argonne, II.
Binder, J. L., L. M. McUmber and B. W. Spencer, April 1993a, Direct Contrinment Heatine Experiments in Zion Nuclear Power Plant Geometry Usine Prototypic Core Materials: The U1A and U1B Tests, ANL/RE/LWR 93-3, Argonne National Laboratory, Argonne, II.

Binder, J. L., L. M. McUmber, and B. W. Spencer, May 1993b, Dirtet Contrinment Heatine Experiments in Zion Nuclear Power Plant Geometry Using Prototypic Core Materials: The UZ Test, ANL/RE/LWR 93-3, Argonne National Laboratory, Argonne, II.

Denning, R. S. et al., July 1986, Radionuclide Release Calculations for Selected Severe Accident Scenarios; Large Dry Containment Design, BMI2139, NUREG/CR-4624, Vol. V, Battelle Memorial Institute, Columbus, $\mathrm{OH}$.

Henry, R. E. et al., 1991, "Direct Containment Heating Experiments in a Zion-Like Geometry," in 26th National Heating Transfer Conference, Vol. 87.

Kumar, R. K., July/August 1985, "Flammability Limits of Hydrogen-Oxygen-Diluent Mixtures," Journal of Fire Sciences, Vol. 3.

Pilch, M. M., Oct. 1991, "Adiabatic Equilibrium Models for Direct Containment Heating," SAND91-2407C, presented at the $19^{\text {h }}$ Water Reactor Safety Information Meeting, Washington, D.C.

Pilch, M. M., M. D. Allen and R. O. Griffith, Aug. 1992, Kinetic Limitations to Adiabatic Equilibrium Models for Direct Containment Heating (DCHD, SAND92-0009C, to be presented in 28th ASME/AICHE/ANS National Heat Transfer Conference, San Diego, CA. 


\section{References}

Spencer, B. W. et al., 1987, Hydrodynamics and Heat Transfer Aspects of Corium-Water Internetions, EPRI NP-5127, Argonne National Laboratory, II.

Tarbell, W. W. et al., 1987, Besults from the DCH-1 Experiment, NUREG/CR-4871, SAND86-2483, Sandia National Laboratories, Albuquerque, NM.

Tarbell, W. W., et al., 1988, DCH-2:_Results from the Second Experiment Performed in the Surtsey Direct Heating Test Facility, NUREG/CR-4917, SAND87-0976, Sandia National Laboratories, Albuquerque, NM.

Tarbell, W. W., M. Pilch, J. W. Ross, M. S. Oliver, D. W. Gilbert and R. T. Nichols, Mar. 1991, Pressurized Melt Ejection Into Water Pools, NUREG/CR-3916, SAND84-1531, Sandia National Laboratories, Albuquerque, NM.
U.S. Nuclear Regulatory Commission, Dec. 1990, Severe Accident Risks: An Assessment for Eive U.S.Nuclear Power Plants, NUREG-1150.

Williams, D. C., 1992, An Interpretation of the Results of Some Recent Direct Containment Heating (DCH) Experiments in the Surtery Eacility, SAND92-0442C, presented at the NURETH-5 Conference, Salt Lake City, UT.

Zuber et al. 1991, An Integrated Structure and Scaline Methodology for Severe Accident Technical Issue Resolution, NUREG/CR-5809, EGG-2659. 


\section{Appendix A \\ A Two-Cell Equillibrium Model for Predicting DCH}

\section{A.1 Introduction}

This appendix describes two adiabatic equilibrium models that are conservatively biased with the intent of bounding or enveloping each of the processes that contribute to containment pressurization. In applying these conservative models, assessment and validation of the separate effects (kinetic) models and the parameters (i.e. particle size) that control them are required only to the extent necessary to confirm that oquilibrium conditions can reasonably be expected. The first, a single-cell model, places a true upper bound on DCH loads. This upper bound when compared with the entire DCH database often far exceeds experiment observations by a margin too large to be useful in reactor analyses. The single-cell model will be used as a conceptual seed for a TCE model.

In this appendix, a TCE model is developed that captures the dominant mitigating features of containment compartmentalization and the noncoherence of the entrainment and blowdown processes. The TCE model has been extensively validated against the relevant DCH database.

The model is a simple tool that can be used to normalize random variations in experiment initial conditions so that experiments can be compared without the possibility of making incorrect conclusions due to these random variations. The relevant elements of the model were presented by Pilch [1991] and Pilch et al. [1992a]. The TCE model will be developed here so that it can be used as a normalization tool in the main body of this report to make specific conclusions about phenomena that enhance or mitigate DCH.

\section{A.2 A Single-Cell Adiabatic Equilibrium Model}

The single-cell adiabatic equilibrium model assumes that the entire containment volume can be treated as a single control volume in which there are no energy sinks. The dispersed debris is assumed to mix completely with the entire containment atmosphere and to remain airborne long enough to enable all thermal and chemical interactions to come to equilibrium. Three moderating factors are reflected in the single-cell model: metal/steam reactions may be steam limited, hydrogen combustion may be oxygen limited, and debris/gas thermal equilibrium renders energy below the equilibrium temperature unavailable for heating the atmosphere. On a containment-wide basis, these moderating factors are nonexistent or second-order effects in typical reactor applications, but they may be considerably more important in selected DCH experiments.

The energy equation for the containment atmosphere is given by

$$
\frac{d U}{d t}=\dot{Q}_{z, 6}+\dot{Q}_{z, 48}+\dot{Q}_{z, H 2}
$$

where the terms on the right hand side (RHS) represent the energy source rates due to RCS blowdown, debris/gas heat transfer, and hydrogen combustion. The energy equation for dispersed debris is given by

$$
\frac{d U_{d}}{d t}=u_{d}\left(T_{d}^{0}\right) \frac{d N_{d}}{d t}+\dot{Q}_{d, s}-\dot{Q}_{g, d q}
$$




\section{Appendix A}

where the first two terms on the RHS represent the energy source rates due to dispersal of debris (which carries thermal energy) into the atmosphere and the subsequent oxidation of the dispersed debris. The third term on the RHS represents the energy loss rate from the debris due to debris/gas heat transfer, which is conservative with the analogous source term in the gas energy equation.

Combining the energy equations for the atmosphere and the dispersed debris yields

$$
\frac{d U}{d t}=\dot{Q}_{g, b}+\dot{Q}_{d, r}+\dot{Q}_{g, H 2}-\frac{d U_{d}}{d t}+u_{d}\left(T_{d}^{0}\right) \frac{d N_{d}}{d t}
$$

The equilibrium state is obtained by integrating this equation from $t=0$ to $t=\infty$,

$$
\mathrm{U}\left(\mathrm{T}_{\mathrm{e}}\right)-\mathrm{U}\left(\mathrm{T}^{0}\right)=\Delta \mathrm{E}_{\mathrm{b}}+\Delta \mathrm{E}_{\mathrm{r}}+\Delta \mathrm{E}_{\mathrm{H} 2}+\left[\mathrm{U}_{\mathrm{d}}\left(\mathrm{T}_{\mathrm{d}}^{0}\right)-\mathrm{U}_{\mathrm{d}}\left(\mathrm{T}_{\mathrm{e}}\right)\right]
$$

where $\Delta \mathrm{E}_{\mathrm{b}}, \Delta \mathrm{E}_{\mathrm{r}}$, and $\Delta \mathrm{E}_{\mathrm{H} p}$ are the maximum contribution that RCS blowdown, debris ox: tation, and hydrogen combustion can make to changes in the atmosphere internal energy. The last grouping in this equation,

$$
\mathrm{U}_{\mathrm{d}}\left(\mathrm{T}_{\mathrm{d}}^{0}\right)-\mathrm{U}_{\mathrm{d}}\left(\mathrm{T}_{\mathrm{e}}\right)
$$

represents the thermal energy released by the debris while approaching equilibrium with the gas. This term cannot be quantified because the equilibrium temperature $\left(T_{e}\right)$ is not yet known. The following discussion addresses this difficulty.

The debris internal energy can be indexed to a reference temperature by adding and subtracting a reference energy to Equation A.5:

$$
U_{d}\left(T_{d}^{0}\right)-U_{d}\left(T_{e}\right)=U_{d}\left(T_{d}^{0}\right)-U_{d}\left(T_{x}\right)-\left[U_{d}\left(T_{e}\right)-U_{d}\left(T_{r}\right)\right]
$$

which can be simplified partially to

$$
U_{d}\left(T_{d}^{0}\right)-U_{d}\left(T_{e}\right)=\Delta E_{t}-\left[U_{d}\left(T_{e}\right)-U_{d}\left(T_{t}\right)\right]
$$

where $\Delta \mathrm{E}_{\mathrm{l}}$ is the maximum internal energy content of all dispersed debris relative to the reference temperature. 
The following decomposition based on the caloric equation of state coupled with a useful rearrangement yields

$$
U_{d}\left(T_{c}\right)=N_{d} C_{d} T_{e}=\left(N^{0}+N_{b}\right) C_{v} T_{e} \frac{N_{d} C_{d}}{\left(N^{0}+N_{b}\right) C_{v}}=U\left(T_{e}\right) \psi
$$

where

$$
\psi=\frac{N_{d} C_{d}}{\left(N^{0}+N_{b}\right) C_{v}}
$$

is a ratio of heat capacitances. The implication is that blowdown gas augments the containment atmosphere as the heat sink for debris energy. Here it is assumed that the molar heat capacities of the gases (atmosphere and blowdown gas) are constant and the same. The molar specific heat of the debris is also assumed constant and includes the heat of fusion by smearing it over the temperature range $T_{r}$ to $T_{d}^{0}$. A similar manipulation yields

$$
U_{d}\left(T_{r}\right)=U\left(T_{r}\right) \psi
$$

Taking advantage of these manipulations, the maximum change in the total internal energy of the containment atmosphere can be written as

$$
\Delta \mathrm{U}=\mathrm{U}_{\mathrm{d}}\left(\mathrm{T}^{0}\right)-\mathrm{U}\left(\mathrm{T}^{0}\right)=\frac{\Delta \mathrm{E}_{\mathrm{b}}+\Delta \mathrm{E}_{\mathrm{\imath}}+\Delta \mathrm{E}_{\mathrm{r}}+\Delta \mathrm{E}_{\mathrm{H} 2}}{1+\psi},
$$

where an energy term

$$
\Delta E=-\left[U_{d}\left(T^{0}\right)-U_{d}\left(T_{t}\right)\right]=-N_{d} C_{d}\left(T^{0}-T_{t}\right)
$$

has been dropped from the numerator as negligible compared to the other energy terms. The term represents about a three percent correction to the thermal energy term to account for the fact that debris cooldown is bounded on the low side by the initial containment temperature and not the reference temperature. The maximum pressure rise in the containment resulting from DCH can be obtained by combining the caloric equation of state for the atmosphere internal energy with the ideal gas law and an identity for the ratio of gas specific heats. 
Appendix A

Doing so yields

$$
\frac{\Delta \mathrm{P}}{\mathrm{P}^{0}}=\frac{\Delta \mathrm{U}}{\mathrm{U}^{0}}=\frac{\sum \Delta \mathrm{E}_{\mathrm{i}}}{\mathrm{U}^{0}(1+\psi)} .
$$

This is the working equation for the single-cell equilibrium model. The term, $1+\psi$, appears because thermal energy below the debris/gas equilibrium temperature is unavailable for heating the atmosphere. This is a second-order effect on a containment-wide basis.

The earliest considerations of DCH [CLWG 1985] identified containment water (in the cavity or on the containment basement floor) as a potential mitigator of DCH. Simple energy arguments support containment water as a mitigator because energy absorbed in vaporizing water will not contribute to increased atmospheric temperature. Although vaporized water adds moles of steam to the containment atmosphere leading to increased pressure, the resulting pressure rise would be considerably less than if all the energy went into heating the atmosphere. Consequently, containment water is a potential mitigating factor.

This simplistic energy argument does not reflect the kinetics of debris/water interactions. Experiments [Spencer et al. 1987; Allen et al. 1992a] have shown that cavity water can enhance debris dispersal from the cavity; however, the bounding model already assumes complete dispersal from the cavity for RCS pressures greater than $4 \mathrm{MPa}$. CONTAIN calculations [Williams et al. 1987] have indicated that efficient water interactions in the cavity can increase the peak pressure by as much as 20 percent compared to a dry scenario for a wide range of water masses ( $\leq 100 \mathrm{MT}$ ). This calculated effect is dominated by predictions of enhanced transport of debris through the subcompartment to the upper dome, which has not been observed in experiments. Only modest increases in peak pressure and hydrogen production [Henry et al. 1991; Allen et al. 1992a; Spencer et al. 1987] have been observed in experiments. The SNL/IET-8B was conducted with a cavity half full of water, and a modest decrease in pressure was observed. Analyses of the WC-1 and WC-2 experiment results [Allen et al. 1992a] suggest that only a small fraction of the available water participates in the interactions. This conclusion is supported by other experiment observations [Tarbell et al. 1991] where violent debris/water interactions in the cavity expel the bulk of the water from the cavity as a slug. For these reasons, cavity water is not expected to jeopardize the bounding nature of the models developed here.

The various terms and material properties necessary to fully quantify a result are discussed next.

\section{A.2.1 Molar Inventory of the Containment Atmosphere and the RCS}

The molar inventory of the containment atmosphere can be expressed (by the ideal gas law) in terms of known conditions in the containment prior to vessel breach,

$$
\mathrm{N}^{0}=\frac{\mathrm{P}^{0} \mathrm{~V}}{\mathrm{R}_{\mathrm{u}} \mathrm{T}^{0}} .
$$


Appendix A

Blowdown of the RCS to ambient conditions adds mass to the containment atmosphere. The amount of blowdown gas can be computed from the difference in the initial and final states in the RCS, which for an isentropic blowdown of an ideal gas can be written as

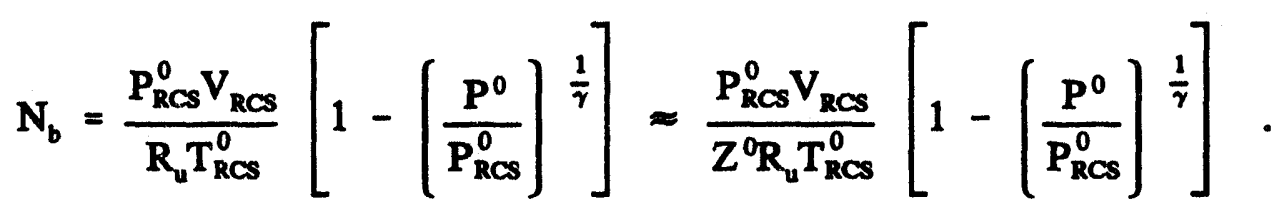

The term preceding the brackets represents the molar inventory of the RCS prior to vessel breach, while the term in the square brackets represents the fraction of the initial inventory that is actually convected into the containment. The fraction of RCS gas delivered to the containment is usually near unity and a second-order correction; however, high-pressure steam near saturation is not well represented as an ideal gas. The approximate expression shown in Equation A.15 accommodates this departure from the ideal by introducing a compressibility factor (which is on the order of 0.75 for saturated steam at elevated RCS pressures) into the evaluation of the initial RCS inventory. The compressibility factor is computed exactly for each experiment or reactor application.

\section{A.2.2 Amount of Debris Participating in DCH}

The number of debris moles participating in DCH can be related to the initial molar inventory of molten core naterial on the lower head of the RPV at the time of vessel breach,

$$
\mathbf{N}_{d}=\mathbf{f}_{\text {dimp }} \mathbf{f}_{\text {cject }} \mathbf{N}_{d}^{0}
$$

where $f_{\text {cject }}$ is the fraction of melt initially on the lower head of the RPV that is ejected into the reactor cavity, and $f_{\text {disp }}$ is the fraction of melt ejected into the reactor cavity that is subsequently dispersed into the containment.

Analyses of gas blowthrough and two-phase melt ejection during HPME [Pilch and Griffith 1992b] suggest that virtually all molten material in the bottom of the RPV at the time of vessel breach is ejected into the reactor cavity (i.e., $f_{\text {cject }} \approx 1.0$ ). Recent integral effects DCH experiments [Allen et al. 1992ch; Allen et al. 1993; Binder et al. 1992 ${ }^{7}$ ] exhibited about 10 percent retention of melt as a frozen crust in the melt generator. Retention by freezing, which is controlled by the surface/volume ratio of the melt, is expected to be less effective at full scale. Experiment analyses will be performed using measured values of $f_{\text {ejoct }}$ while reactor analyses will be based on complete ejection of melt from the RPV in order to bound uncertainties in melt ejection processes.

No reactor cavity can be considered retentive at the high RCS pressures of interest. Predictions of DCH experiments will be based on measured values of the dispersed fraction, while reactor predictions will assume complete dispersal in order to bound uncertainties in dispersal phenomena.

7 J.L. Binder, et al., 1992, Quick Look Data Report on the Integral Effects Test $\# 2$ in the Corexit Facility at Argonne National Laboratory, Argonne National Laboratory, Argonne, IL. 
Appendix A

The conventional approach to DCH analyses assumes that only dispersed debris (because it is highly fragmented) can contribute significantly to containment pressurization on DCH time scales. More recently, Williams [1992] has speculated that even debris that is not dispersed from the reactor cavity can interact significantly with blowdown gas. The current models bound Williams' interpretation when melt ejection and dispersal are assumed complete.

\section{A.2.3 Energy Source Resulting from RCS Blowdown}

The energy gained by the containment atmosphere from blowdown of the RCS is balanced by the energy loss from the RCS by the same process,

$$
\frac{\mathrm{dU}_{\mathrm{g}, \mathrm{b}}}{\mathrm{dt}}=-\frac{\mathrm{dU}_{\mathrm{RCS}}}{\mathrm{dt}}=\frac{\mathrm{V}_{\mathrm{RCS}}}{\gamma-1} \frac{\mathrm{dP}_{\mathrm{RCS}}}{\mathrm{dt}} .
$$

The blowdown energy can be bounded by assuming that the RCS pressure reduces to the initial containment pressure,

$$
\Delta \mathrm{E}_{\mathrm{b}}=-\Delta \mathrm{U}_{\mathrm{RCS}}=\frac{\mathrm{V}_{\mathrm{RCS}} \mathrm{P}_{\mathrm{RCS}}^{0}}{\gamma-1}\left[1-\frac{\mathrm{P}^{0}}{\mathrm{P}_{\mathrm{RCS}}^{0}}\right] .
$$

The term preceding the brackets represents the total internal energy of the RCS, while the bracketed term represents the fraction of this total that is convected into the containment.

\section{A.2.4 Energy Source from Debris Thermal Energy}

Molten debris dispersed from the reactor cavity carries both latent and sensible heat that can be transferred to the containment atmosphere. The thermal energy contribution represents the total internal energy of the dispersed debris referenced to the initial temperature of the atmosphere,

$$
\Delta E_{t}=U_{d}\left(T_{d}^{0}\right)-U_{d}\left(T_{r}\right)=N_{d}\left[u_{d}\left(T_{d}^{0}\right)-u_{d}\left(T_{r}\right)\right]=N_{d} \Delta u_{d}=N_{d} C_{d}\left(T_{d}^{0}-T_{r}\right)
$$

where the later equalities explicitly show the dependence on the amount of participating debris. The specific molar internal energy is indexed to the reference temperature $(298 \mathrm{~K})$, and it is both temperature and composition dependent.

\section{A.2.5 Energy Source from Debris Oxidation}

The metallic components of dispersed debris can also react with available steam to release energy to the debris and form hydrogen. The metallic components of molten core material consists of steel (chromium and iron) and possibly zirconium metal. Although zirconium and chromium are present in relatively small quantities, their combustion usually dominates the magnitude of the oxidation energy, which can be comparable to the thermal energy contribution for some published melt compositions [Zuber et al. 1991]. Oxidation of metallic components is expected to occur in a hierarchical fashion: 
zirconium, chromium, and iron (in that order). Consequently, the preferential oxidation of a small quantity of material can supply virtually all the oxidation energy. However, the oxidation of iron, although almost neutral energetically, cannot be ignored in the production of hydrogen. Almost assuredly there is sufficient blowdown steam in any reactor application to react those metals that dominate the reaction energy, which is assumed to be fully realized without regard to potential kinetic limitations. Together these assumptions favor both simplicity and a bounding result.

DCH experiments sometimes employ a chromium-laced $\mathrm{Fe} / \mathrm{Al}_{2} \mathrm{O}_{3}$ thermite as a simulant for the molten core materials expected in a reactor accident. This melt also contains trace quantities of aluminum, which behave like zirconium in the reactor melt. The assumptions and conclusions discussed above are equally applicalie to this simulant material.

The maximum energy release resulting from debris oxidation can be written as

$$
\Delta E_{r}=N_{d} \Delta h_{r} \delta_{r, s t m}
$$

where the molar heat of reaction is dependent on the composition of the melt. Note that the contribution of debris oxidation to DCH loads is also dependent on the amount of material participating in DCH.

A steam limit to the oxidation energy is introduced largely to accommodate those experiments that have been conducted with nonreactive blowdown gases (e.g., nitrogen or carbon dioxide).

The factor,

$$
\delta_{r, \Delta t m}=\frac{\sum N_{d, i} \Delta h_{r, i} \min \left[\frac{N_{s t m, i}}{\nu_{d, i} N_{d, i}} ; 1\right]}{\sum N_{d, i} \Delta h_{r, i}},
$$

represents the fraction of the oxidation energy that is released by consuming the available steam. The summation is evaluated in a hierarchial manner starting with the most reactive metal. The limiting factor in the minimization function represents the ratio of available steam to the steam required to oxidize the metal at a current level of the hierarchy. The stoichiometric coefficient, $\nu_{\mathrm{d}, \mathrm{i}}$, represents the moles of steam consumed per mole of metal. The steam available at the start of each level in the hierarchy is obtained from the recursion formula,

$$
\mathbf{N}_{\mathrm{stm}, \mathrm{i}}=\max \left[0 ; \mathrm{N}_{\mathrm{stm}, \mathrm{i}-1}-\nu_{\mathrm{d}, \mathrm{i}} \mathbf{N}_{\mathrm{d}, \mathrm{i}}\right] \text {, }
$$

which takes as its seed the initial number of steam moles in the RCS, $\mathbf{N}_{\text {stm }, 1}=\mathbf{N}_{\text {RCs. }}^{0}$ Excluding applications with inert blowdown gases, $\delta_{r, m}$ is almost always near unity.

There are four sources of oxidant with which the metals can react: oxygen in the atmosphere, steam in the atmosphere, blowdown steam, and water in the cavity or on the basement floor. On a containment-wide basis, there generally is sufficient oxidant to oxidize all the metal in the debris. The 


\section{Appendix A}

debris will preferentially oxidize with oxygen when available, and this is the more energetic reaction. If debris does react with steam, however, then hydrogen is produced that may subsequently combust with the available oxygen; in which case the net energy release of the cycle would be the same as if the debris burned directly with oxygen.

Although the net energy release is the same, there are subtle differences that should be recognized. In the former case (debris/oxygen reactions), all the chemical energy is released in the debris droplet, thus increasing its temperature and the likelihood of continued oxidation.

In the second case (debris/steam reactions), only a portion of the chemical energy is deposited in the debris droplet, thus resulting in a lower value for the maximum possible debris temperature. The remaining chemical energy appears when the hydrogen produced by the debris/steam reaction burns elsewhere in the containment atmosphere. This energy from hydrogen combustion is released directly to the containment atmosphere. This is the basis for the modeling here because it is assumed that the greater portion of debris oxidation occurs with steam in the reactor cavity and the plume of material as it exits the cavity. There is very little oxygen available in these regions.

\section{A.2.6 Energy Source Resulting from Hydrogen Combustion}

Hydrogen combustion is normally inerted by steam in most severe accident scenarios. DCH is unique in that it can heat the containment atmosphere, possibly to the point where steam can no longer inert the combustion of hydrogen. Simplicity and a bounding result are obtained by assuming that all available hydrogen is burned completely (subject only to a possible oxygen limitation) during the DCH event. The maximum energy release from hydrogen combustion can then be written as

$$
\Delta \mathrm{E}_{\mathrm{H} 2}=\left(\mathrm{N}_{\mathrm{H} 2, \mathrm{RCB}}+\mathrm{N}_{\mathrm{HL}, \mathrm{RCS}}+\nu_{\mathrm{d}} \mathrm{N}_{\mathrm{d}} \delta_{\mathrm{HL}, \mathrm{\Delta am}}\right) \Delta \mathrm{h}_{\mathrm{H} 2} \delta_{\mathrm{H} 2,02}
$$

where $\Delta \mathrm{h}_{\mathrm{HL}}$ is the molar combustion energy. Three sources of hydrogen must be considered: preexisting hydrogen in the containment atmosphere that was released from the RCS prior to vessel breach, hydrogen injected into the atmosphere at the time of vessel breach as part of the blowdown gases, and hydrogen produced from debris/steam reactions as part of the DCH event.

Hydrogen production resulting from debris oxidation is subject to a possible steam limitation,

$$
\delta_{\mathrm{H} 2, \mathrm{sm}}=\frac{\sum \nu_{\mathrm{d}, \mathrm{i}} \mathbf{N}_{\mathrm{d}, \mathrm{i}} \min \left[\frac{\mathbf{N}_{\mathrm{sm}, \mathrm{i}}}{\nu_{\mathrm{d}, \mathrm{i}} \mathbf{N}_{\mathrm{d}, \mathrm{i}}} ; 1\right]}{\sum \nu_{\mathrm{d}, \mathrm{i}} \mathbf{N}_{\mathrm{d}, \mathrm{i}}},
$$

which is evaluated in a hierarchial manner similar to the analogous term in the oxidation energy term. The stoichiometric coefficient ( $\nu_{\mathrm{d}, \mathrm{i}}$ moles of hydrogen produced / mole of metal oxidized) is identical to the previously introduced stoichiometric coefficient because one mole of steam always produces one mole of hydrogen. In reactor applications, there usually is sufficient steam (on a global basis) to burn 
all the available hydrogen. Some experiments, however, have intentionally inerted the containment atmosphere, so it is useful to recognize a possible oxygen limitation to hydrogen combustion,

$$
\delta_{\mathrm{H} 2,02}=\min \left[\frac{2 \mathrm{~N}_{\mathrm{O} 2}^{\circ}}{\mathbf{N}_{\mathrm{H} 2, \mathrm{RCB}}+\mathbf{N}_{\mathrm{H} 2, \mathrm{RCS}}+\nu_{\mathrm{d}} \mathbf{N}_{\mathrm{d}} \delta_{\mathrm{H} 2, \mathrm{am}}} ; 1\right] .
$$

\section{A.2.7 Material Properties}

Table A.1 lists the specific molar properties of melt species that are present in molten core material and iron/alumina thermite, which is often used as a surrogate for core material in DCH experiments. The heat capacity is treated as a constant, which is chosen so that reported values of the specific internal energy are matched at $2500 \mathrm{~K}$. The heat capacities, therefore, include the heat of fusion by implicitly smearing it over the entire temperature range. The specific molar internal energy is temperature dependent with the representative values evaluated at $2500 \mathrm{~K}$. The remaining terms are also treated as constants.

Table A.2 lists the specific molar hrat capacities of gas species that typically make up a containment atmosphere or that have been employed in DCH experiments. The specific heats are treated as constants, which are evaluated at elevated temperatures to better predict the atmospheric heat sink during a DCH transient.

Effective mixture properties for the molten debris or the containment atmosphere can be computed as a mole fraction average of the species properties when the composition is specified. Representative mixture values are listed in Tables A.1 and A.2. These mixture values are based on the typical melt and atmosphere compositions listed in Tables A.3 and A.4. In any given experiment or reactor application, mixture properties specific to the actual melt and atmosphere compositions are employed.

\section{A.3 Two-Cell Adiabatic Equilibrium Model}

The two-cell adiabatic equilibrium model extends the previous results in order to capture much of the mitigating effects associated with containment compartmentalization, which prevents the efficient mixing of airborne debris with the entire atmosphere by confining the bulk of the debris to the subcompartment of the containment. The essential requirements are that there are no line-of-flight paths for dispersed debris to reach the upper dome under its own inertia and that the subcompartment be sufficiently large that gas velocities diffuse to the point where flowing gas is no longer capable of levitating debris $(\sim 1 \mathrm{~mm})$ through various vent spaces to the dome. The latter requirement is perhaps overly conservative because debris does not easily respond to changes in flow direction without deentraining into sheltered regions of low gas velocity; and most containment subcompartments (Zion included) require multiple changes in flow direction before vent spaces can be reached.

The primary heat sink for debris in this confined subcompartment geometry is that portion of the blowdown gas that is coherent with the dispersal processes, which may be augmented by portions of 


\section{Appendix A}

the subcompartment atmosphere. Thermal equilibrium between debris and this limited heat sink retains more energy in the debris, which is unavailable for additional heating of the atmosphere.

The moderating factors recognized in the single-cell model are retained here, and they are supplemented by additional features that could furcher limit the magnitude of containment pressures:

1. metal/steam reactions may be steam limited,

2. hydrogen combustion may be oxygen limited,

3. debris/gas thermal equilibrium renders energy below the equilibrium temperature unavailable for heating the atmosphere,

4. chemical equilibrium could limit the amount of hydrogen produced from iron/steam reactions,

5. hydrogen combustion as a diffusion flame may be inerted, and

6. the ignition threshold for volumetric combustion of preexisting hydrogen may not be reached.

The containment is typically divided into two main volumes: upper dome and subcompartment. For a pressurized water reactor (PWR), the subcompartment typically comprises the reactor cavity and the region generally located beneath the operating floor, bounded by the crane wall and the refueling canal wall. The upper dome comprises the remainder of the containment. Debris can be dispersed from a PWR cavity through two possible flow paths. The first flow path typically exists so that incore instrument guide tubes can have access to the lower head of the RPV. Debris dispersal through this path will enter the containment subcompartment.

A second path for debris dispersal is through an annular gap surrounding the RPV. Debris dispersed through this path enters the upper dome of the containment. The annular gap usually is partially filled with reflective insulation. The insulation is mostly void with layers of metal foil retained by thin sheet metal. The fate of the insulation under severe accident conditions is a matter of speculation. The insulation may plug the annular gap. The analysis presented here allows for the possibility that both flow paths can exist.

The premise of the two-cell model is that DCH occurs independently in the subcompartment and the upper dome, $\Delta \mathrm{U}=\Delta \mathrm{U}_{1}+\Delta \mathrm{U}_{2}$. It will be shown that the individual contributions can be written as the product of a pressure efficiency and the maximum internal energy change based on the single cell model,

$$
\Delta \mathrm{U}=\left(\eta_{1}+\eta_{2}\right)(\Delta \mathrm{U})_{1 \mathrm{c}},
$$


Appendix A

so that the containment pressurization can be conveniently written as

$$
\frac{\Delta \mathrm{P}}{\mathrm{P}^{0}}=\left(\eta_{1}+\eta_{2}\right)\left(\frac{\Delta \mathrm{P}}{\mathrm{P}^{0}}\right]_{1 \mathrm{c}} .
$$

The efficiency of DCH processes in the subcompartment and the upper dome are developed next.

\section{A.3.1 DCH Processes in the Subcompartment}

Blowdown gas and debris are assumed to enter the subcompartment in the ratio of the flow area to the subcompartment to the total flow area from the cavity. This is partially supported by the HIPS-8C experiment [Pilch et al. 1988]. The heat sink for debris/gas heat transfer has two physical limits. The first limit conceptually corresponds to a limit where debris is injected into the subcompartment like a shotgun blast with little or no blowdown gas. In this limit, the maximum heat sink is the gas initially residing in the subcompartment. The second limit corresponds to the case where debris dispersal is accompanied by large quantities of blowdown gas. In this limit, the heat sink is that portion of the blowdown gas that is coherent with the dispersal process. For intermediate cases, the heat sink (and DCH loads) can be bounded by taking the maximum of the two limits. Physically, this means some or all of the subcompartment atmosphere will be displaced to the dome before DCH interactions take place. In either limit, hydrogen combustion is insignificant in the subcompartment because metal/steam reactions typically produce far more hydrogen than the local inventory of oxygen can burn and because most of this subcompartment oxygen may be pushed to the dome by injection of hot blowdown gas into the subcompartment.

The energy gained by gas in the subcompartment can be written as

$$
\Delta U_{1}=\frac{f_{a 1}\left(\Delta E_{b}+\Delta E_{1}+\Delta E_{r}\right)-f_{a 1} N_{d} C_{d}\left(T_{1}^{0}-T_{r}\right)}{1+\psi_{1}},
$$

where

$$
\psi_{1}=\frac{f_{a 1} N_{d} C_{d}}{\max \left[f_{a 1} f_{c o b} N_{R C S}^{0} ; f_{v 1} N^{0}\right] C_{v}}
$$

is the local heat capacitance ratio in the subcompartment. On a global basis, the heat capacitance ratio is generally a second-order effect; but in compartmentalized containment geometry, debris/gas heat transfer can be reduced drastically in the subcompartment because of large values of $\psi_{1}$.

The heat sink for the debris gas interactions can have a temperature ranging from the initial containment temperature to the initial temperature in the RCS, depending on whether the subcompartment atmosphere or the blowdown gas dominates as the heat sink. In general, neither dominates and mixing of the two gases forces an intermediate temperature approximated by 
Appendix A

$$
T_{1}=\frac{f_{a 1} f_{c o b} N_{R C S}^{0} T_{R C S}^{0}+f_{v 1} N^{0} T^{0}}{f_{a 1} f_{c o t} N_{R C s}^{0}+f_{v 1} N^{0}}
$$

On a global basis, the heat sink correction to the thermal energy term, $\mathbf{N}_{d} \mathbf{C}_{d}\left(\mathbf{T}^{0}-\mathbf{T}_{\mathrm{f}}\right)$, is quite insignificant. The correction can be important, however, in reactor applications where the hot blowdown gas can dominate the heat sink in the subcompartment.

Changes in the subcompartment internal energy can be normalized by the internal energy change predicted by the single-cell equilibrium model,

$$
\Delta U_{1}=\frac{f_{a 1}\left(\Delta E_{b}+\Delta E_{1}+\Delta E_{r}\right)-f_{21} N_{d} C_{d}\left(T_{1}^{0}-T_{r}\right)}{\left(1+\psi_{1}\right)(\Delta U)_{1 c}}(\Delta U)_{1 c} .
$$

Doing so allows one to define a pressure efficiency,

$$
\eta_{1}=\frac{f_{a 1}\left(\Delta E_{b}+\Delta E_{t}+\Delta E_{r}\right)-f_{21} N_{d} C_{d}\left(T_{1}^{0}-T_{t}\right)}{\left(1+\psi_{1}\right)(\Delta U)_{1 C}},
$$

characterizing the contribution of subcompartment processes to peak DCH loads. The three energy terms $\left(\Delta \mathrm{E}_{b}, \Delta \mathrm{E}_{\mathrm{l}}\right.$, and $\left.\Delta \mathrm{E}_{\mathrm{r}}\right)$ are identical to their counterparts in the single-cell model. It is useful to add and subtract a hydrogen combustion energy identical to the term in the single-cell model. The correction ' $\rightarrow$ the thermal energy term can also be normalized by $T_{d}{ }^{\circ}-T_{r}$. Lastly, the internal energy change from the single-cell model is given by Equation A.11. Taken together, the subcompartment efficiency can be written as

$$
\eta_{1}=\frac{1+\psi}{1+\psi_{1}} \frac{\left[\mathrm{f}_{21}\left(\sum \Delta \mathrm{E}_{\mathrm{i}}\right)_{1 \mathrm{C}}-\mathrm{f}_{\mathrm{a1}}\left(\Delta \mathrm{E}_{\mathrm{H} 2}\right)_{1 \mathrm{C}}-\mathrm{f}_{\mathrm{al}} \mathrm{N}_{\mathrm{d}} \mathrm{C}_{\mathrm{d}}\left(\mathrm{T}_{\mathrm{d}}^{0}-\mathrm{T}_{\mathrm{r}}\right) \frac{\mathrm{T}_{1}-\mathrm{T}_{\mathrm{r}}}{\mathrm{T}_{\mathrm{d}}^{0}-\mathrm{T}_{\mathrm{r}}}\right]}{\left(\sum \Delta \mathrm{E}_{\mathrm{i}}\right)_{1 \mathrm{C}}}
$$

which after a final simplification becomes

$$
\eta_{1}=\mathrm{f}_{\mathrm{a} 1} \frac{1+\psi}{1+\psi_{1}}\left[1-\left(\frac{\Delta \mathrm{E}_{\mathrm{kP}}}{\sum \Delta \mathrm{E}_{\mathrm{i}}}\right]_{\mathrm{lc}}-\left[\frac{\Delta \mathrm{E}_{\mathrm{i}}}{\sum \Delta \mathrm{E}_{\mathrm{i}}}\right]_{\mathrm{lc}} \frac{\mathrm{T}_{1}-\mathrm{T}_{\mathrm{r}}}{\mathrm{T}_{\mathrm{d}}^{0}-\mathrm{T}_{\mathrm{r}}}\right] .
$$

The DCH efficiency for the subcompartment is written in terms of known quantities from the single-cell model. Equation A.34 reflects three mitigating factors for the subcompartment: a limited heat sink 
Appendix A

reflected in a large value of $\psi_{1}$, no hydrogen combustion, and a heat sink that is hotter than the reference temperature.

\section{A.3.2 DCH Processes in the Dome}

The dome region of a reactor containment building typically involves more than ninety percent of the containment volume. Development of an energy equation for the dome parallels that for the subcompartment with the notable exception that some or all of the hydrogen can burn in the dome, regardless of where it is produced.

The energy gained by gas in the dome can be written as

$$
\Delta U_{2}=\frac{f_{22}\left(\Delta E_{b}+\Delta E_{1}+\Delta E_{r}\right)+N_{H 2, b u m n} \Delta e_{H 2}-f_{22} N_{d} C_{d}\left(T_{2}-T_{r}\right)}{1+\psi_{2}}
$$

where the local capacitance ratio is given by

$$
\psi_{2}=\frac{f_{{ }_{2}} N_{d} C_{d}}{\max \left[f_{22} f_{\text {cot }} N_{R C S}^{\circ} ; f_{v 2} N \cdot C_{v}\right.},
$$

and where the heat sink temperature is given by

$$
T_{2}=\frac{f_{22} f_{c o b} N_{R C S}^{\circ} T_{R C S}^{\circ}+f_{v 2} N^{\circ} T^{\circ}}{f_{22} f_{c o b} N_{R C S}^{\circ}+f_{\sqrt{ } 2} N^{\circ}}
$$

A DCH efficiency for the dome can be developed in a manner similar to that for the subcompartment,

$$
\eta_{2}=\frac{f_{22}\left(\Delta E_{b}+\Delta E_{1}+\Delta E_{r}\right)+N_{k D, b u m} \Delta e_{k D}-f_{22} N_{d} C_{d}\left(T_{2}-T_{r}\right)}{\left(1+\psi_{2}\right)(\Delta U)_{1 c}}
$$

A more useful result is obtained by adding and subtracting a hydrogen combustion energy equivalent so that in the one-cell model, by normalizing the amount of hydrogen burned by the total hydrogen bumed in the one-cell model, and by normalizing the reference energy correction to the thermal energy term by $T_{d}{ }^{\circ}-T_{r}$. With these suggestions, the efficiency of DCH processes in the dome can be written as

$$
\eta_{2}=\frac{1+\psi}{1+\psi_{2}}\left[\mathrm{f}_{\mathrm{a2}}-\left(\mathrm{f}_{\mathrm{a2}}-\mathrm{f}_{\mathrm{bum}}\right)\left[\frac{\Delta \mathrm{E}_{\mathrm{Hz}}}{\sum \Delta \mathrm{E}_{\mathrm{i}}}\right]_{\mathrm{lc}}-\left[\frac{\Delta \mathrm{E}_{\mathrm{t}}}{\sum \Delta \mathrm{E}_{\mathrm{i}}}\right]_{\mathrm{lc}} \frac{\mathrm{T}_{2}-\mathrm{T}_{\mathrm{r}}}{\mathrm{T}_{\mathrm{d}}^{0}-\mathrm{T}_{\mathrm{r}}}\right],
$$


where

$$
f_{b u r n}=\frac{N_{\text {HQ, bure }}}{\left(N_{\text {HQ, burn }}\right)_{\text {IC }}}
$$

is the fraction of hydrogen that could bum in the dome and actually does. This term will be quantified in Section A.3.4.

\section{A.3.3 Coherence of Blowdown Gas with Debris Dispersal}

Dispersed debris first interacts with that portion of the blowdown gas that is coherent with the dispersal process, which is often the limiting heat sink in reactor applications. Furthermore, coherent steam is the sole source of oxidant for hydrogen producing reactions on a time scale that can contribute to peak containment pressurization. The coherent fraction of the blowdown gas, assuming isentropic blowdown of the RCS, is computed from

$$
f_{\text {coth }}=1-\left[1+\frac{\gamma-1}{2} \frac{\tau_{e}}{\tau_{b}}\right]^{\frac{-2}{\gamma-1}}
$$

where $\tau_{d} / \tau_{b}$ is the ratio of the characteristic dispersal (entrainment) time to the characteristic blowdown time.

\section{A.3.4 Hydrogen Combustion in the Dome}

Hydrogen combustion occurs predominantly, if not entirely, in the dome of the reactor containment, which typically comprises at least 90 percent of the total volume. This is because the subcompartment contains only a small fraction of the containment's oxygen; and much of what is there initially will be pushed to the dome by the debris/gas plume exiting the cavity. Unfortunately, hydrogen combustion in the dome is most efficient because oxygen limitations are not likely to come into play and because the combustion energy goes almost entirely into heating the atmosphere (i.e., $\psi_{2}$ is small in the dome).

Three sources of hydrogen must be considered: preexisting hydrogen in the containment atmosphere that was released from the RCS prior to vessel breach, hydrogen injected into the atmosphere at the time of vessel breach as part of the blowdown gases, and hydrogen produced from debrisi steam reactions as part of the DCH event. Chemical equilibrium could limit the amount of hydrogen from iron/steam reactions. Hydrogen in the subcompartment will be heated as part of the DCH event. The subsequent expansion will expel this hydrogen into the dome through various vent paths. These hot hydrogen jets are assumed to burn as diffusion flames, entraining preexisting hydrogen along with the oxygen necessary to sustain combustion. In some cases, DCH processes may heat the containment atmosphere sufficiently to induce autoignition and volumetric combustion of any remaining preexisting hydrogen. These concepts are quantified in the following discussions. 
Hydrogen can be produced from metal reactions with the coherent part of the blowdown gas. Consider first the reactive metals $(\mathrm{Zr}, \mathrm{Al}$, and $\mathrm{Cr})$. The amount of hydrogen produced, subject only to a possible steam limitation, is given by

$$
N_{H 2}(R M)=\sum_{i=1}^{R M} \nu_{i} N_{d, i} \min \left[\frac{f_{\text {oot }} N_{\text {sTM }, i} ; 1}{\nu_{i} N_{d, i}}\right]
$$

where the summation is evaluated in the hierarchical fashion discussed previously. Lastly, iron can oxidize and produce hydrogen,

$$
\mathbf{N}_{\mathrm{Hz}}(\mathrm{Fe})=\mathbf{X}_{\mathrm{PeO}} \nu_{\mathrm{Fe}} \mathbf{N}_{\mathrm{d}, \mathrm{Pe}}^{0}
$$

if excess steam is still available. The factor, $\mathbf{X}_{\mathrm{PeO}}$, represents the amount of iron that is oxidized, which could be limited by chemical equilibrium even if steam is present.

Iron oxidizes according to the reaction,

$$
\mathrm{Fe}+\mathrm{H}_{2} \mathrm{O} \rightarrow \mathrm{FeO}+\mathrm{H}_{2}
$$

at high temperatures. At chemical equilibrium, the mole fraction of $\mathrm{FeO}$ is given by

$$
X_{\mathrm{FOO}}=\frac{\frac{\mathrm{y}_{\mathrm{HOO}}}{\mathrm{y}_{\mathrm{HD}}} \mathrm{K}_{\mathrm{eq}}}{1+\frac{\mathrm{y}_{\mathrm{HDO}}}{\mathrm{y}_{\mathrm{HL}}} \mathrm{K}_{\mathrm{eq}}}
$$

where $\mathrm{K}_{\mathrm{eq}}$ is the equilibrium constant (a function of temperature only), which has a value of about $\mathrm{K}_{\mathrm{eq}}$ $\sim 2.1$ on the temperature range $2000 \mathrm{~K}$ to $3000 \mathrm{~K}$. By definition,

$$
X_{\mathrm{FeO}}=\left[\frac{\mathbf{N}_{\mathrm{PeO}}}{\mathbf{N}_{\mathrm{FeO}}+\mathbf{N}_{\mathrm{Pe}}}\right]_{\mathrm{eq}}=\frac{\left(\mathrm{N}_{\mathrm{P} \infty O}\right)_{\mathrm{eq}}}{\mathbf{N}_{\mathrm{Fe}}^{\circ}}=\frac{\left(\mathrm{N}_{\mathrm{Fe}}\right)_{\mathrm{eq}}}{\mathbf{N}_{\mathrm{Pe}}^{\circ}},
$$

which shows that $\mathrm{X}_{\mathrm{Fco}}$ also represents the fraction of iron that is oxidized. 

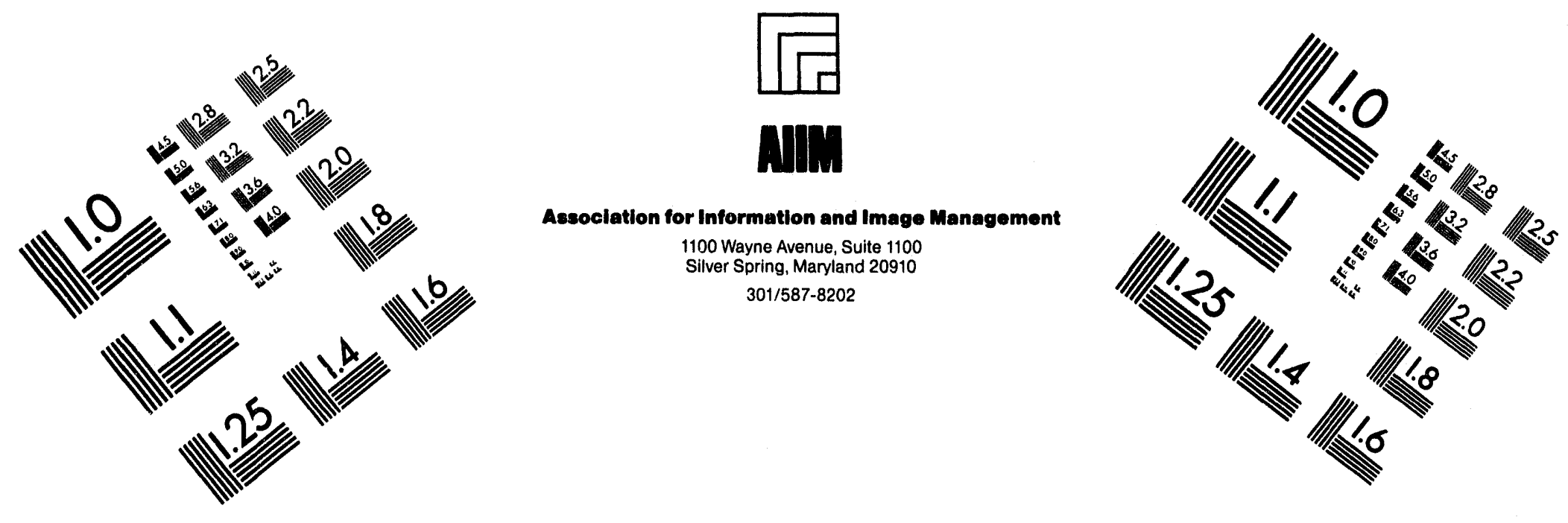

\section{Centimeter}

$\begin{array}{llllllllllllllll}1 & 2 & 3 & 4 & 5 & 6 & 7 & 8 & 9 & 10 & 11 & 12 & 13 & 14 & 15 & \mathrm{~mm}\end{array}$ L.m.m.

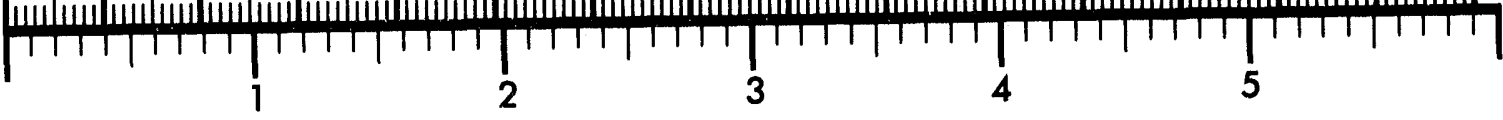
Inches
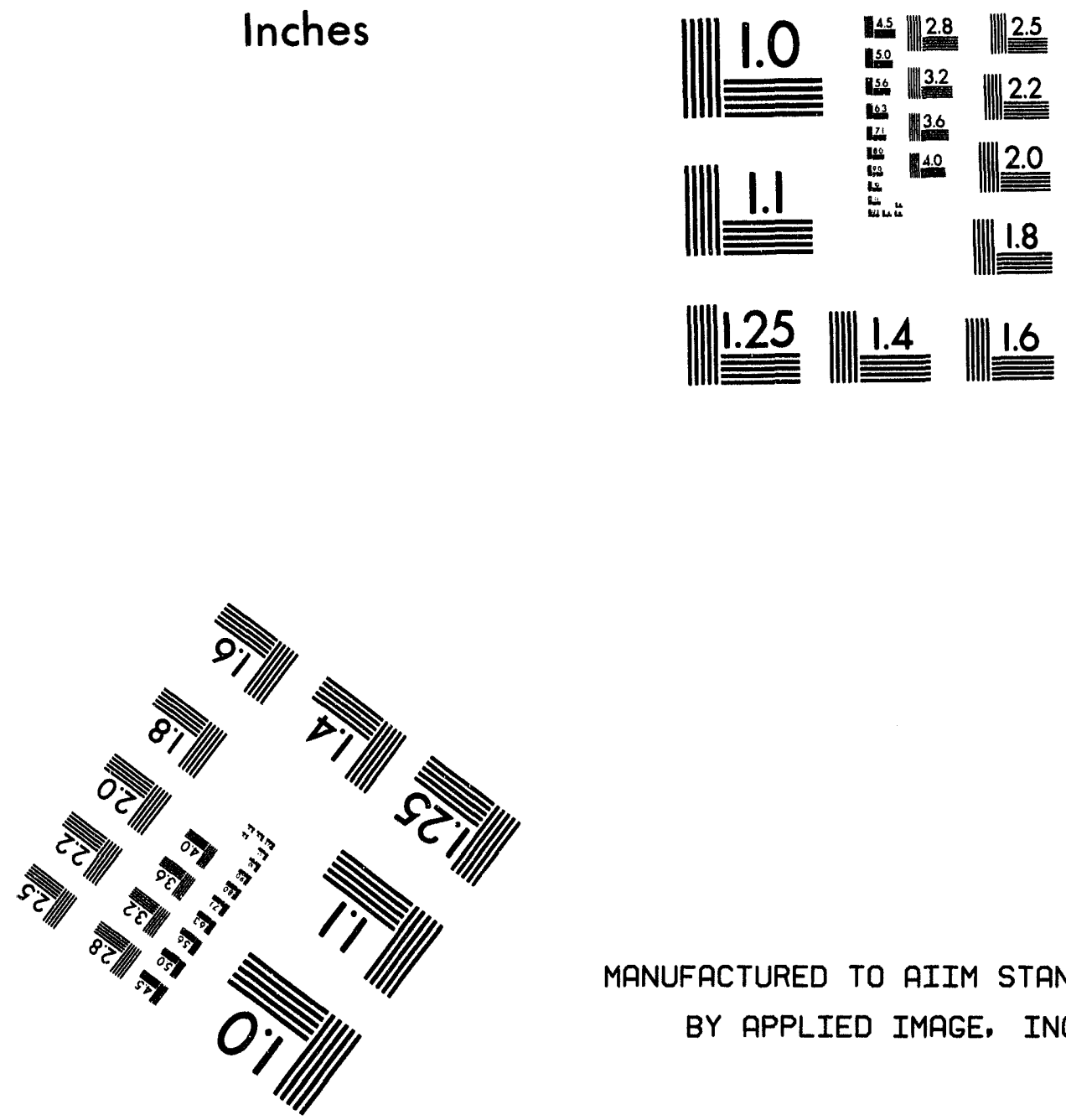

MANUFACTURED TO AIIM STANDARDS

BY APPLIED IMAGE, INC.

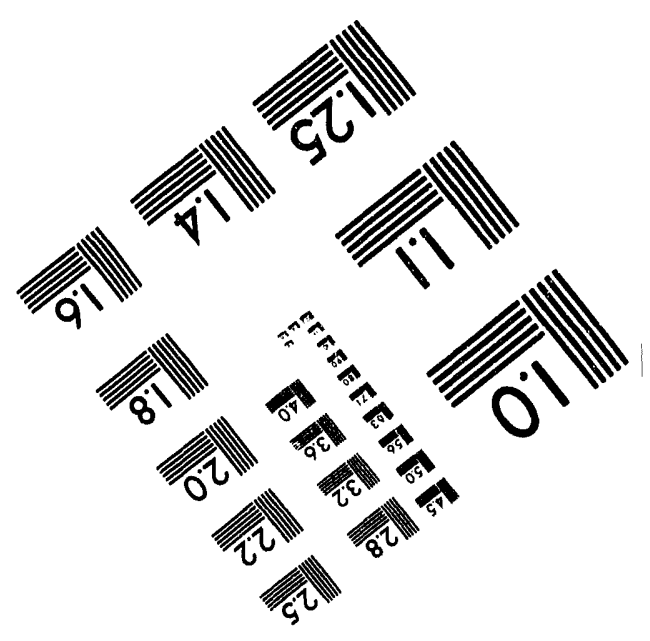



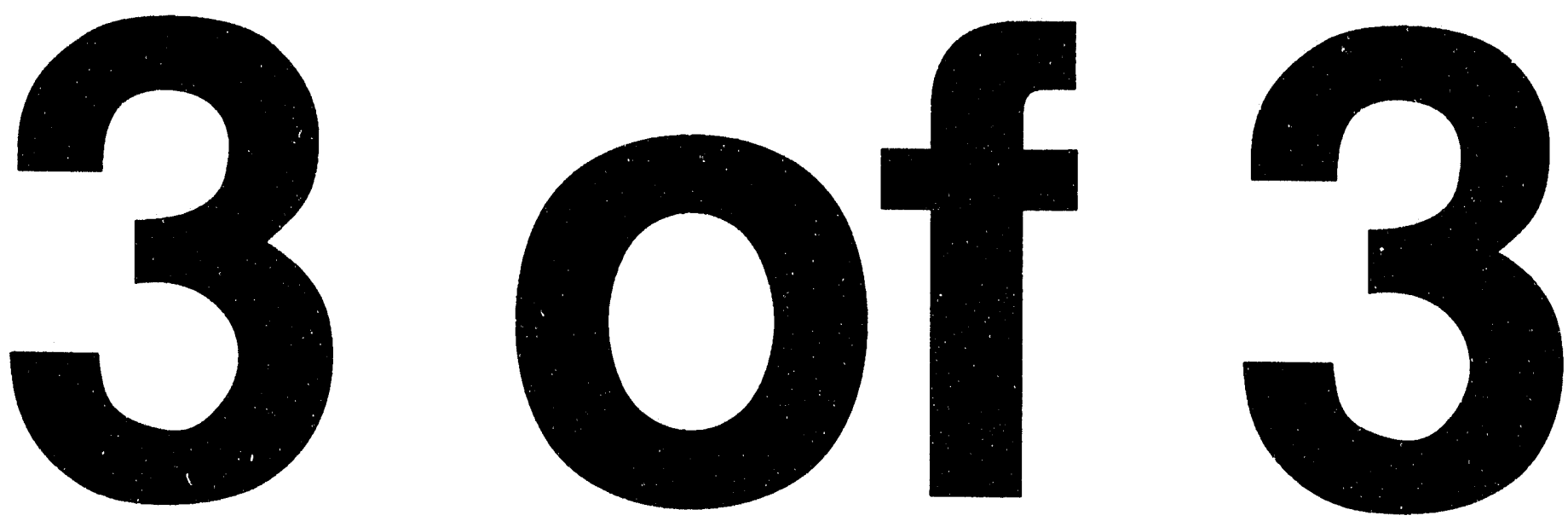


\section{Appendix A}

The steam/hydrogen ratio controls the amount of hydrogen that is oxidized. By definition,

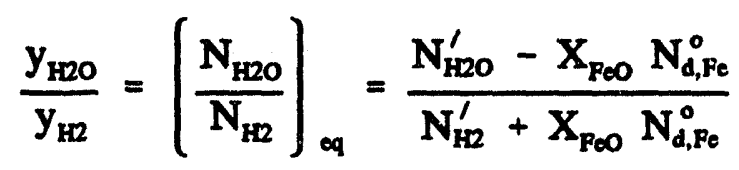

where $\mathbf{N}_{\mathrm{HZO}}^{\prime}$ and $\mathbf{N}_{\mathrm{Hz}}^{\prime}$ are the moles of steam and hydrogen in contact with the iron when oxidation with the reactive metals is complete. These quantities can be related back to known RCS conditions by

$$
\begin{aligned}
& \mathbf{N}_{\mathrm{H} 2 \mathrm{O}}^{\prime}=\mathrm{f}_{\text {cob }} \mathbf{N}_{\mathrm{H} 2 \mathrm{O}, \mathrm{RCS}}^{\circ}-\mathbf{N}_{\mathrm{HL}}(\mathrm{RM}) \\
& \mathbf{N}_{\mathrm{HL}}^{\prime}=\mathrm{f}_{\text {cot }} \mathbf{N}_{\mathrm{H} 2, \mathrm{RCS}}^{\circ}+\mathbf{N}_{\mathrm{HZ}}(\mathbf{R M}) .
\end{aligned}
$$

Equations A.50 - A.52 can be combined with Equation A.48 to form a quadratic for $\mathrm{X}_{\mathrm{PeO}}$, the solution of which is given by

$$
X_{\mathrm{FeO}}=\frac{B}{2}\left[1-\left[1-\frac{4 C}{B^{2}}\right]^{1 / 2}\right]
$$

where

$$
\begin{gathered}
\mathrm{B}=\frac{\mathrm{K}_{\mathrm{eq}}}{\mathrm{K}_{\mathrm{eq}}-1}\left[1+\frac{\mathbf{N}_{\mathrm{H} 2 \mathrm{O}}^{\prime}}{\mathbf{N}_{\mathrm{d}, \mathrm{Fe}}^{\circ}}+\frac{1}{\mathbf{K}_{\mathrm{eq}}} \frac{\mathbf{N}_{\mathrm{HL}}^{\prime}}{\mathbf{N}_{\mathrm{d}, \mathrm{Fe}}^{\circ}}\right] \\
\mathrm{C}=\frac{\mathrm{K}_{\mathrm{eq}}}{\mathrm{K}_{\mathrm{eq}}-1} \frac{\mathbf{N}_{\mathrm{H} 2 \mathrm{O}}^{\prime}}{\mathbf{N}_{\mathrm{d}, \mathrm{Fe}}^{\circ}} .
\end{gathered}
$$

This completes the information required to compute the total amount of hydrogen produced from metal/steam reactions.

Most of the preexisting hydrogen in the subcompartment will be pushed to the dome when the debris/gas plume enters the subcompartment dome, so that hydrogen in the subcompartment is comprised of blowdown hydrogen and hydrogen produced from metal/steam reactions,

$$
\mathbf{N}_{\mathrm{HZ}}(\mathrm{jet})=\mathrm{f}_{\mathrm{a} 1} \mathbf{N}_{\mathrm{HL}, \mathrm{RCS}}^{\circ}+\mathbf{N}_{\mathrm{HL}}(\mathrm{RM})+\mathbf{N}_{\mathrm{HL}}(\mathrm{Fe}) .
$$


This hydrogen will be heated by the DCH event, and the resulting expansion will expel most of this hydrogen to the dome.

Hot hydrogen/steam jets entering the upper dome are expected to burn as standing diffusion flames. This has been observed in SNL and ANL counterpart DCH experiments. Other experiments in the test series, however, have shown that if the atmosphere is inerted sufficiently, the combustion of the hot jet can be extinguished entirely. Demonstration that hydrogen jets will not burn under some reactor conditions could lead to large margins of safety; consequently, there is a need to define the threshold conditions for a hot hydrogen jet where oxygen must be entrained from the environment in order to sustain combustion.

Williams [1992] has supplied such a threshold condition. Consider a hot hydrogen/steam jet with temperature $T_{j}$ entering the oxygen-bearing dome region. Hydrogen can burn only if some oxygenbearing atmosphere is entrained into the jet. The entrained atmosphere comes in cold, and it must be heated by combustion to at least the jet temperature,

$$
\delta \mathrm{N}_{\mathrm{e}} \mathrm{C}_{\mathrm{p}}\left(\mathrm{T}_{\mathrm{j}}-\mathrm{T}^{0}\right) \leq 2 \mathrm{X}_{\mathrm{O} 2} \delta \mathrm{N}_{\mathrm{e}} \Delta \mathrm{e}_{\mathrm{H} 2}
$$

otherwise the jet temperature cannot be sustained. This cooling of the jet causes a crisis because the chemical reactions are so strongly temperature dependent. Williams [1992] suggested that there is a jet temperature of about $1000 \mathrm{~K}$ below which combustion could not be sustained. This is closely related to the autoignition temperature for hydrogen jets, which Stamps and Berman [1991] report to be about $1000 \mathrm{~K}$. This defines a critical oxygen concentration for the atmosphere,

$$
\left(\mathrm{X}_{\mathrm{O} 2}\right)_{\text {crit }}=\frac{1}{2} \frac{\mathrm{C}_{\mathrm{p}}\left[\mathrm{T}_{\mathrm{j}}-\mathrm{T}^{\circ}\right]}{\Delta \mathrm{e}_{\mathrm{H} 2}},
$$

below which jet combustion is incomplete as it cools to the threshold temperature. The critical oxygen concentration takes its minimum value when the jet temperature just equals the threshold temperature.

This criterion explains only partially the existing experiment database for jet combustion, and it would not limit jet combustion in most DCH scenarios. More restrictive criteria might be expected when one focuses on the competition between chemical kinetics and the kinetics of the entrainment/dilution processes. These kinetic considerations suggest that the threshold for jet combustion is scale dependent and much more restrictive at a small scale. Review of a related phenomenon, blowoff of diffusion flames, also suggests a similar scale dependence. Here, small-scale jets may not burn while combustion of sufficiently large jets is absolutely stable. Thus, failure to sustain a diffusion flame in some smallscale experiments might be an artifact of scale alone and not other DCH conditions. Confirmation of these ideas might come from $1 / 6^{\text {th }}$ scale DCH tests to be conducted at Sandia National Laboratories.

The hot hydrogen/steam jet can burn only because oxygen is entrained into the jet; assuming of course, that the threshold criterion for jet combustion is met. Entrainment also carries some of the preexisting hydrogen into the hot jet, and this entrained hydrogen can also burn. The total amount of jet hydrogen and preexisting hydrogen that can burn in the diffusion flame can be written as 
Appendix A

$$
\mathbf{N}_{\mathrm{HD}}(\text { flame })=\mathbf{N}_{\mathrm{H} 2}(\text { jet })+\mathbf{f}_{\mathrm{pre}} \mathbf{N}_{\mathrm{kL}}^{0}
$$

where

$$
\mathbf{N}_{\mathrm{H} 2}(\text { jet })=\mathbf{N}_{\mathrm{HZ}, \mathrm{RCS}}^{0}+\mathbf{N}_{\mathrm{H} 2}(\mathrm{RM})+\mathbf{N}_{\mathrm{HL}}(\mathrm{Fe})
$$

is the total of all hydrogen that is produced in the cavity and subcompartment that has the potential to reach the dome by vents or through the annular gap around the RPV.

Stamps ${ }^{8}$ suggested that the fraction of preexisting hydrogen that is entrained and burned in the jet can be bounded by assuming that enough atmosphere is entrained to burn the jet hydrogen that enters the dome plus any entrained hydrogen,

$$
N_{\mathrm{HD}} \text { (jet) }+\mathrm{X}_{\mathrm{H} 2} \mathrm{~N}_{\mathrm{e}}=2 \mathrm{X}_{\mathrm{O} 2} \mathrm{~N}_{\mathrm{e}}
$$

The entrained fraction is then obtained by normalizing the moles of atmosphere entrained by the initial number of moles in the atmosphere,

$$
f_{p r e}=\frac{N_{e}}{N^{0}}=\frac{N_{\mathrm{H}}(j e t)}{N^{0}} \frac{1}{2 X_{02}-X_{H 2}}
$$

Not all the preexisting hydrogen in the containment atmosphere will be entrained into the jet and burn. In general, a quantity $\left(1-f_{p r e}\right) N_{k D}^{\circ}$ remains. This remaining hydrogen can bum in the dome, subject only to possible oxygen limitations, if the peak containment temperature first reaches a temperature of about $800 \mathrm{~K}$ (reactor scale); at which point, autoignition and volumetric combustion of the remaining hydrogen occurs. Quantification of the autoignition temperature is discussed by Pilch et al. ${ }^{9}$, but it is worth noting that the autoignition temperature is expected to increase somewhat with decreasing facility scale.

The total amount of hydrogen burned can be normalized by the total hydrogen burned in the one-cell model,

$$
f_{\text {bum }}=\frac{N_{\mathrm{HE}} \text { (bumed) }}{\left(\mathbf{N}_{\mathrm{HR}}\right)_{1 \mathrm{C}}} \text {. }
$$

${ }^{8}$ D.W. Stamps, 1992, private communication, Sandia National Laboratories, Albuquerque, NM.

9 M.M. Piich, 1993, "Autoignition Temperatures in DCH Events," to be published in The Probability of Containment Failure by Direct Containment Heating in Zion, draft for comment, Sandia National Laboratories, Albuquerque, NM. 
Appendix A

From the preceding discussions, three cases must be considered:

$$
f_{\text {burs }}=0
$$

when the threshold criterion for jet combustion is not reached,

$$
f_{\text {bum }}=\frac{N_{\mathrm{H} 2} \text { (flame) } \min \left[\frac{2 N_{\mathrm{O} 2}^{\circ}}{\mathbf{N}_{\mathrm{Hz}} \text { (flame) }} ; 1\right]}{\left(\mathbf{N}_{\mathrm{H} 2}\right)_{1 \mathrm{C}}}
$$

when a diffusion flame burns, and

$$
f_{\text {burn }}=1.0
$$

when DCH processes in conjunction with a diffusion flame autoignite preexisting hydrogen. 
Appendix A

Table A.1 Specific molar properties of debris

\begin{tabular}{|c|c|c|c|c|}
\hline Species & $\underset{\mathrm{J} / \mathrm{mole} / \mathbf{K}}{\mathbf{C}_{\mathbf{d}}}$ & $\begin{array}{l}\Delta u_{d}(2500) \\
M J / m o l e\end{array}$ & $\begin{array}{c}\Delta h_{\mathrm{r}} \\
\mathbf{M J} / \text { mole }\end{array}$ & mole-F2/mole \\
\hline $\mathbf{Z r}$ & 42.315 & 0.0932 & 0.598 & 2 \\
\hline $\mathrm{Al}$ & 35.667 & 0.0785 & 0.397 & 1.5 \\
\hline $\mathrm{Cr}$ & 44.668 & 0.0984 & 0.207 & 1.5 \\
\hline $\mathrm{Fe}$ & 47.712 & 0.1051 & 0.002 & 1 \\
\hline $\mathbf{N i}$ & 44.250 & 0.0974 & 0 & 0 \\
\hline $\mathrm{UO}_{2}$ & 126.55 & 0.2787 & 0 & 0 \\
\hline $\mathrm{ZrO}_{2}$ & 116.87 & 0.2573 & 0 & 0 \\
\hline $\mathrm{Al}_{2} \mathrm{O}_{3}$ & 163.20 & 0.3594 & 0 & 0 \\
\hline Corium & 75.01 & 0.165 & 0.111 & 0.765 \\
\hline Thermite & 74.7 & 0.0164 & 0.042 & 0.843 \\
\hline
\end{tabular}

Table A.2 Specific molar heat capacity

of containment atmosphere

\begin{tabular}{cc}
\hline Species & $\begin{array}{c}\mathbf{C}_{\mathbf{v}} \\
\mathbf{J} / \mathbf{m o l e} / \mathbf{K}\end{array}$ \\
\hline $\mathrm{O}_{2}$ & 25.9 \\
$\mathrm{~N}_{2}$ & 24.1 \\
$\mathrm{H}_{2} \mathrm{O}$ & 32.4 \\
$\mathrm{H}_{2}$ & 21.2 \\
$\mathrm{CO}_{2}$ & 33.1 \\
$\mathrm{Ar}$ & 12.5 \\
Atmosphere & 28.52 \\
\hline
\end{tabular}


Table A.3 Representative composition of corium and thermite

\begin{tabular}{ccccc}
\hline & \multicolumn{2}{c}{ Corium } & \multicolumn{2}{c}{ Thermite } \\
\cline { 2 - 5 } Species & $\begin{array}{c}\text { Mass } \\
\text { fraction }\end{array}$ & $\begin{array}{c}\text { Mole } \\
\text { fraction }\end{array}$ & $\begin{array}{c}\text { Mass } \\
\text { fraction }\end{array}$ & $\begin{array}{c}\text { Mole } \\
\text { fraction }\end{array}$ \\
\hline $\mathrm{Zr}$ & 0.1250 & 0.1528 & 0 & 0 \\
$\mathrm{Al}$ & 0 & 0 & 0.0130 & 0.0316 \\
$\mathrm{Cr}$ & 0.0430 & 0.0920 & 0.1080 & 0.1363 \\
$\mathrm{Fe}$ & 0.1620 & 0.3218 & 0.5050 & 0.5916 \\
$\mathrm{Ni}$ & 0.0200 & 0.0377 & 0 & 0 \\
$\mathrm{UO}_{2}$ & 0.3900 & 0.1607 & 0 & 0 \\
$\mathrm{ZrO}_{2}$ & 0.2600 & 0.2351 & 0 & 0 \\
$\mathrm{Al}_{2} \mathrm{O}_{3}$ & 0 & 0 & 0.3740 & 0.2405 \\
\hline
\end{tabular}

Table A.4 Representative composition of a containment atmosphere

\begin{tabular}{cc}
\hline Species & Mole fraction \\
\hline $\mathrm{O}_{2}$ & 0.1055 \\
$\mathrm{~N}_{2}$ & 0.3968 \\
$\mathrm{H}_{2} \mathrm{O}$ & 0.4877 \\
$\mathrm{H}_{2}$ & 0.0202 \\
$\mathrm{CO}_{2}$ & 0 \\
$\mathrm{Ar}$ & 0 \\
\hline
\end{tabular}


Appendix A
A.4 Nomenclature
$\mathrm{C}_{\mathrm{d}} \quad=$ molar heat capacity of debris
$\mathrm{C}_{\mathrm{v}} \quad=$ molar heat capacity of the containment atmosphere
$\mathrm{f}_{\text {dipp }}=$ fraction of melt ejected into the reactor cavity that is dispersed into the containment
$f_{a 1}=$ fraction of the total flow area from the reactor cavity that communicates with the subcompartment
$f_{22}=1-f_{n 1}=$ fraction of total flow area from the reactor cavity that communicates with the upper dome
$\mathrm{f}_{\text {bum }} \quad=$ fraction of hydrogen that could burn in the dome and actually does
$\mathrm{f}_{\text {coh }}=$ fraction of blowdown gas coherent with debris dispersal
$\mathrm{f}_{\text {eject }} \quad=$ fraction of melt initially in the RCS that is ejected into the reactor cavity
$\mathrm{K}_{\mathrm{eq}} \quad=$ equilibrium constant
$\mathrm{f}_{\mathrm{pre}} \quad=$ fraction of preexisting hydrogen burned
$f_{\mathrm{v} 1}=$ fraction of the containment volume occupied by the subcompartment
$\mathrm{N}_{\mathrm{b}} \quad$ = number of gas moles added to the containment by RCS blowdown
$\mathrm{N}_{\mathrm{d}} \quad=$ number of moles of debris participating in $\mathrm{DCH}$
$\mathbf{N}_{\mathrm{Hz}}$ (flame) = moles of hydrogen burned in diffusion flame
$\mathbf{N}_{\mathrm{HD}, \mathrm{RCB}}{ }^{\circ}=$ initial number of hydrogen moles in the reactor containment building
$\mathbf{N}_{\mathrm{HD}, \mathrm{RCS}} \quad=$ moles of hydrogen ejected from the RCS during blowdown
$\mathbf{N}_{\mathrm{Hz}}(\mathrm{RM}) \quad=$ moles of hydrogen produced by oxidizing reactive metals
$\mathbf{N}_{\mathrm{kz}}(\mathrm{Fe}) \quad=$ moles of hydrogen produced by oxidizing iron
$\mathbf{N}^{\circ} \quad=$ number of gas moles initially in the containment
$\mathbf{N}_{d}^{0} \quad=$ moles of molten debris initially present in the RPV at the time of vessel breach
$\mathbf{N}_{\mathrm{d}, \mathrm{Fe}^{\circ}} \quad=$ initial moles of iron dispersed in melt
$\mathbf{N}_{\mathrm{Hz}}$ (jet) = moles of hot hydrogen sourced to dome as a jet 
$\mathbf{N}_{\mathrm{HzO}, \mathrm{RCS}}^{\circ}=$ moles of steam initially in RCS

$\mathbf{N}_{O_{2}}{ }^{\circ} \quad=$ moles of oxygen initially in containment atmosphere

Po $\quad=$ initial containment pressure

$\mathbf{P}_{\mathrm{RCs}}, \mathbf{P}_{\mathrm{RCS}}^{0}=$ pressure and initial pressure of the $\mathrm{RCS}$

$\dot{\mathrm{Q}}_{\mathrm{d}, \mathrm{r}} \quad=$ energy source rate due to debris oxidation

$\dot{\mathrm{Q}}_{g, \mathrm{~b}} \quad=$ energy source rate due to RCS blowdown

$\dot{Q}_{\text {g,d }}=$ energy source (sink) rate due to debris/gas heat transfer

$\dot{\mathrm{Q}}_{\mathrm{g}, \mathrm{H2}} \quad=$ energy source rate due to hydrogen combustion

$\mathbf{R}_{\mathbf{u}} \quad=$ universal gas constant

$\mathrm{T}_{\mathrm{e}} \quad=$ debris/gas equilibrium temperature

$\mathbf{T}^{0} \quad=$ initial temperature of the containment atmosphere

$T_{d}^{0} \quad=$ initial temperature of airborne debris

$\mathrm{T}_{\mathrm{j}} \quad=$ source temperature of hot hydrogen jet

$\mathrm{T}_{\mathrm{r}} \quad=$ reference temperature, $298 \mathrm{~K}$

$\mathrm{T}_{\mathrm{RCS}}^{0} \quad=$ initial gas temperature of the RCS

$u_{d} \quad=$ molar internal energy of airborne debris

$u_{d, i} \quad=$ molar internal energy of the $i^{\text {th }}$ species in the airborne debris

$\mathrm{U}=$ internal energy of the entire containment atmosphere

$U_{d} \quad=$ internal energy of all dispersed debris

$U^{\circ} \quad=$ initial internal energy of the entire containment atmosphere

$\mathrm{U}_{\mathrm{RCS}} \quad=$ internal energy of RCS gas 
Appendix A

$\mathrm{V}^{0} \quad=$ containment volume

$\mathrm{V}_{\mathrm{RCS}}^{0}=\mathrm{RCS}$ volume

$\mathrm{X}_{\mathrm{F} 0 \mathrm{O}}=$ fraction of iron in dispersed melt that is oxidized

$\left(\mathrm{X}_{02}\right)_{\text {crit }} \quad=$ critical oxygen concentration to support jet combustion

$\mathrm{Z}^{0} \quad=$ compressibility factor for high-pressure steam near saturation

\section{GREEKS}

$\gamma \quad=C_{\rho} / C_{v}$ is the isentropic exponent of blowdown gas

$\Delta \mathrm{E}_{\mathrm{b}} \quad=$ maximum energy contribution due to blowdown

$\Delta \mathrm{E}_{\mathrm{FD}} \quad=$ maximum energy contribution due to hydrogen combustion

$\Delta \mathrm{E}_{\mathrm{T}} \quad=$ maximum energy contribution due to debris oxidation

$\Delta \mathrm{E}_{\mathrm{q}} \quad=$ maximum energy contribution due to debris oxidation

$\Delta \mathrm{e}_{\mathrm{H}} \quad=$ molar heat of reaction for hydrogen combustion

$\Delta h_{r}, \Delta h_{r, i}=$ debris and species oxidation energies

$\delta_{\mathrm{r}, \mathrm{STM}}=$ steam limitation to debris oxidation energy

$\delta_{\mathrm{ED}, \mathrm{STM}}=$ steam limitation to hydrogen production

$\delta_{\mathrm{H}, 02}=$ oxygen limitation to hydrogen combustion

$\Delta \mathbf{P} \quad=$ pressure rise in the containment resulting from the $\mathrm{DCH}$ event

$\Delta u_{d} \quad=$ specific molar internal energy of debris referenced to initial temperature of containment atmosphere

$\Delta \mathrm{U} \quad=$ total internal energy gained by the containment atmosphere

$\Delta \mathrm{U}_{1}, \Delta \mathrm{U}_{2}=$ internal energy gained in subcompartment and upper dome atmospheres, respectively

$\nu_{\mathrm{d}}, \nu_{\mathrm{d}, \mathrm{i}}=$ stoichiometric coefficient (moles of hydrogen produced/moles of debris) for debris oxidation or species

$\eta_{1}, \eta_{2} \quad=$ pressure efficiency for subcompartment and upper dome respectively 
$\sigma_{\text {biex }} \quad=$ relative bias between predictions and measurements

$\sigma_{\operatorname{mis}} \quad=$ relative $\mathrm{RMS}$ between predictions and measurements

$\tau_{\mathrm{e}} \quad=$ characteristic entrainment time

$\tau_{\mathrm{b}}=$ characteristic blowdown time

$\psi \quad=$ heat capacitance ratio

$\psi_{1}, \psi_{2}=$ heat capacitance ratio for the subcompartment and upper dome respectively 
Appendix A

\section{A.5 References}

Allen, M. D., M. Pilch, R. O. Griffith and R. T. Nichols, Mar. 1992a, Experiments to Investigate the Effect of Water in the Cavity on Direct Containment Heating (DCH) in the Surtsey Test Facility The WC-1 and WC-2 Tests, SAND91-1173, Sandia National Laboratories, Albuquerque, NM.

Allen, M. D., M. Pilch, R. O. Griffith, R. T. Nichols and T. K. Blanchat, July 1992c, Experiments to Investigate the Effects of 1:10 Scale Zion Structures on Direct Containment Heating (DCH) in the Surtsey Test Facility: The IET-1 and IET-1R Tests, SAND92-0255, Sandia National Laboratories, Albuquerque, NM.

Allen, M. D., M. Pilch, R. O. Griffith, D. C. Williams and R. T. Nichols, June 1992d, The Third Integral Effects Test (IET-3) in the Surtsey Test Facility, SAND92-0166, Sandia National Laboratories, Albuquerque, NM.

Allen, M. D., T. K. Blanchat, M. Pilch and R. T. Nichols, Sept. 1992e, The Effects of Condensate Levels of Water on Direct Containment Heating (DCH) in Zion-Like Geometry: The Fourth Integral Effects Test (IET-4) Conducted in the Surtsey Test Facility, SAND92-1241, Sandia National Laboratories, Albuquerque, NM.

Allen, M. D., T. K. Blanchat, M. Pilch and R. T. Nichols, Nov. 1992f, Experimental Results of an Integral Effects Test in a Zion-Like Geometry to Investigate the Effects of a Classically Inert Atmosphere on Direct Containment Heating: The IET-5 Experiment, SAND92-1623, Sandia National Laboratories, Albuquerque, NM.

Allen, M. D., T. K. Blanchat, Martin Pilch and R. T. Nichols, Nov. 1992g, An Integral Effects Test in a Zion-Like Geometry to Investigate the effects of Preexisting Hydrogen on Direct Containment Heating in the Surtsey Test Facility - The IET-6 Experiment, SAND92-1802, Sandia National Laboratories, Albuquerque, NM.

Allen, M. D., T. K. Blanchat, Martin Pilch and R. T. Nichols, Nov. 1992h, An Integral Effects Test to Investigate the Effects of Condensate Levels of Water and Preexisting Hydrogen on Direct Containment Heating in the Surtsey Test Facility - The IET-7 Experiment, SAND92-2021, Sandia National Laboratories, Albuquerque, NM.

Allen, M. D., T. K. Blanchat, M. Pilch and R. T. Nichols, 1993, Experiments to Investigate the Effects of Fuel/Coolant Interactions on Direct Containment Heating - The IET-8A and IET-8B Experiments, SAND92-2849, Sandia National Laboratories, Albuquerque, NM.

Binder, J. L., et al., 1992, Quick Look Data Report on the Integral Effec:s Test \#2 in the Corexit Facility at Argonne National Laboratory, Argonne National Laboratory, Argonne, IL.

CLWG, 1985, Estimates of Early Containment Loads from Core Melt Accidents, NUREG-1079, U.S. Nuclear Regulatory Commission, Washington, D.C. 
Henry, R. E. et al. 1991, "Direct Containment Heating Experiments in a Zion-like Geometry," in 26th National Heating Transfer Conference, Vol. 87.

Pilch, M., W. W. Tarbell and J. E. Brockmann, Sept. 1988, The Influence of Selected Containment Structures on Debris Dispersal and Transport Following High Pressure Melt Ejection from the Reactor Vessel, NUREG/CR-4914, SAND87-0940, Sandia National Laboratories, Albuquerque, NM.

Pilch, M. M., M. D. Allen and R. O. Griffith, 1992a, "Kinetic Limitations to Adiabatic Equilibrium Models for Direct Containment Heating," SAND92-000C, in 28th ASME/AICHE/ANS National Heat Transfer Conference San Diego, CA, Aug. 9-12.

Pilch, M. and R. O. Griffith, June 1992b, Gas Blowthrough and Flow Quality Correlations for Use in the Analysis of Pressure Melt Ejection (HPME) Events, SAND91-2322, Sandia National Laboratories, Albuquerque, NM.

Spencer, B. W., J. J. Sienicki and L.M. McUmber, Mar. 1987, Hydrodynamics and Heat Transfer Aspects of Corium-Water Interactions, EPRI NP-5127, Argonne National Laboratory, IL.

Stamps, D. W. and M. Berman, 1991, "High-Temperature Hydrogen Combustion in Reactor Safety Applications," NSE, 109, 39-48.

Tarbell, W. W., Mar. 1991, Pressurized Melt Ejection into Water Pools, NUREG/CR-3916, SAND84-1531, Sandia National Laboratories, Albuquerque, NM.

Williams, D. C., K. D. Bergeron, D. E. Carroll, R. D. Gasser, J. L. Tills and K. E. Washington, May 1987, Containment Loads Due to Direct Containment Heating and Associated Hydrogen Behavior: Analysis and Calculations with the CONTAIN Code, NUREG/CR-4896, SAND870633, Sandia National Laboratories, Albuquerque, NM.

Williams, D. C., Sept. 1992, An Interpretation of the Results of Some Recent Direct Containment Heating (DCH) Experiments in the Surtsey Facility SAND92-0442C, presented at the NURETH-5 Conference, Salt Lake City, UT.

Zuber et al. 1991, An Integrated Structure and Scaling Methodology for Severe Accident Technical Issue Resolution, NUREG/CR-5809, EGG-2659. 


\section{DISTRIBUTION}

U. S. Nuclear Regulatory Commission (4) Office of Nuclear Regulatory Research

Attn: C. Tinkler, NLN-344 R. Lee, NLN-344

A. Rubin, NLN-344

F. Eltawila, NLN-344

B. Sheron, NLS-007

Washington, D.C. 20555

U. S. Nuclear Regulatory Commission (3) NRC/RES

Attn: E. Beckjord, NI S-007

B. Hardin, NLS-169

T. Speis, NLS-007

Washington, D.C. 20555

U. S. Department of Energy

Office of Nuclear Safety Coordination

Attn: R. W. Barber

Washington, D.C. 20545

U. S. Department of Energy (2)

Albuquerque Operations Office

Attn: C. E. Garcia, Director

For: C. B. Quinn

R. L. Holton

P. O. Box 5400

Albuquerque, NM 87185

Los Alamos National Laboratories

Attn: M. Stevenson

P.O. Box 1663

Los Alamos, NM 87545

Electric Power Research Institute

Attn: A. Michaels

3412 Hillview Avenue

Palo Alto, CA 94303

UCLA

Nuclear Energy Laboratory

Attn: I. Catton

405 Hilgaard Avenue

Los Angeles, CA 90024
Brookhaven National Laboratory (3)

Attn: R. A. Bari

T. Pratt

N. Tutu

$130 \mathrm{BNL}$

Upton, NY 11973

Argonne National Laboratory (4)

Attn: J. Binder

C. Johnson

L. Baker, Jr.

B. Spencer

9700 S. Cass Avenue

Argonne, II 60439

Fauske and Associates, Inc.

Attn: R. Henry

16W070 West 83rd Street

Burr Ridge, IL 60952

General Electric Company

Nuclear Energy

Attn: F. J. Moody

175 Curtner Avenue

San Jose, CA 95125

Battelle Columbus Laboratory (2)

Attn: R. Denning

J. Gieseke

505 King Avenue

Columbus, OH 43201

Department of Energy

Scientific and Tech. Info. Center

P. O. Box 62

Oak Ridge, TN 37831

Purdue University

School of Nuclear Engineering

Attn: M. Ishii

West Lafayette, IN 47907 
Distribution

University of Wisconsin

Nuclear Engineering Department

Attn: M. L. Corradini

1500 Johnson Drive

Madison, WI 53706

Richard R. Hobbins

2955 North Fish Creek Rd.

P.O. Box 971

Wilson, WY 83014

Battelle Pacific Northwest Laboratory

Attn: M. Freshley

P. O. Box 999

Richland, WA 99352

Professor Agustin Alonso

E.T.S. Ingenieros Industriales

Jost Gutierrez Abascal, 2

28006 Madrid

SPAIN

Jose Angel Martinez

Sub. Emplazamientos y Programas Coop.

CONSEJO DE SEGURIDAD

NUCLEAR

Justo Dorado 11

28040 MADRID

SPAIN

Juan Bagues

Consejo de Seguridad Nuckan

SOR Angela de la Cruz No 3

Madrid 28056

SPAIN

Gesellschaft fur Reaktorsicherheit (GRS)

Postfach 101650

Glockengrasse 2

5000 Koeln 1

GERMANY
Technische Universitat Munchen

Attn: Professor H. Karwat

8046 Garching, Forschungagelande

Munich

GERMANY

Siegfried Hagen

Kernforschungszentrum Karlsruhe

P.O. Box 3640

D-7500 Karlsruhe 1

GERMANY

Kernforschungszentrum Karlsruhe (2)

Attn: P. Hofmann

B. Kuczera

Postfach 3640

75 Karlsruhe

GERMANY

Klaus Trambauer

Gesellschaft Fuer Reaktorsicherheit

Forschungsgelande

D-8046 Garching

GERMANY

UKAEA (3)

Attn: D. Sweet

S. Kinnersly 203/A32

D. Williams 210/A32

Winfrith, Dorchester

Dorset DT2 8DH

UNITED KINGDOM

UKAEA Culham Laboratory

Attn: B. D. Turland E5.157

Abingdon

Oxfordshire OX14 3DB

UNITED KINGDOM

UKAEA

Reactor Development Division

Attn: T. Butland

Winfrith, Dorchester

Dorset DT2 8DH

UNITED KINGDOM 
M. R. Hayns

AEA Reactor Services

B329

Harwell

Didcot

Oxfordshire OX11 ORA

UNITED KINGDOM

Simon J. Board

CEGB National Power

Barnett Way

Barnwood, Gloucestershire GL4 7RS

ENGLAND

Nigel E. Buttery

Central Elect. Gen. Board, Booths Hall

Chelford Road, Knutsford

Cheshire WA16 8QG

ENGLAND

Thermodynamics \& Rad. Physics, TP-650 (2)

Attn: P. Fasoli-Stella

A. V. Jones

CEC Joint Research Center, Ispra

I-21020 Ispra (Varese)

ITALY

Dr. K. J. Brinkman

Reactor Centrum Nederland

1755 ZG Petten

THE NETHERLANDS

Mr. H. Bairiot, Chief

Department LWR Fuel

Belgonucleaire

Rue de Champde Mars. 25

B-1050 Brussels

BELGIUM

Japan Atomic Energy Research Institute

Severe Accident Research Laboratory

Attn: N. Yamano

Tokai-mura, Naka-gun, Ibaraki-ken

319-11

JAPAN
Japan Atomic Energy Research Institute

Dept. of Fuel Safety Research

Attn: Y. Maruyama

Tokai-Mura, Ibaraki-Ken

319-11

JAPAN

J. R. Walker

Atomic Energy Canada, Ltd.

Chalk River, Ontario

CANADA KOJ IJO

Atomic Energy Canada Ltd.

Attn: Vijay I. Nath

Sheridan Park Res. Comm.

Mississauga, Ontario

CANADA L5K 1B2

Oguz Akalin

Ontario Hydro

700 University Avenue

Toronto, Ontario

CANADA M5G $1 \times 6$

K. N. (Kannan) Tennankore

Safety Research Division

Whiteshell Nuclear Res. Establishment

Pinawa, Manitoba

CANADA ROE $1 L O$

L. A. Simpson

Safety Research Division

Whiteshell Nuclear Res. Establishment

Pinawa, Manitoba

CANADA ROE 1LO

M. Jankowski

IAEA

Division of Nuclear Reactor Safety

Wagranesrstrasse 5

P. O. Box 100

A/1400 Vienna

AUSTRIA 
Distribution

Statens Kamkraftinspektion (2)

Attn: L. Hammer

W. Frid

P. O. Box 27106

S-10252 Stockholm

SWEDEN

Studvik Energiteknik AB

Attn: $\mathbf{K}$. Johansson

S-611 82 Nykoping

SWEDEN

Korea Adv Energy Research Inst

Attn: Hee-Dong Kim

P. O. Box 7

Daeduk-Danji

Taejon 305-353

KOREA

Chang K. Park

Korea Atomic Energy Research Institute

Korea Advanced Energy Research Institute

P.O. Box 7, Daeduk Danji

Taejon 305-353

KOREA

Jong In Lee

Severe Accident Assessment Department

Korea Institute of Nuclear Safety

P.O. Box 16, Daeduk-Danji

Daejeon, 305-353

KOREA

POSTECH

Department of Mechanical Engineering

Attn: Moo Hwan Kim

P. O. Box 125

Kyungbuk 790-600

KOREA

Atomic Energy Council

Attn: Yi-Bin Chen

67, Lane 144

Keedling Road, Section 4

Taipei, Taiwan 106

REPUBLIC OF CHINA

Ms. C. Lecomte

CEN FAR

60-68 Av. du G. Leclerc - B.P.6

92265 Fontenay aux Roses cedex

FRANCE

Dr. A. Meyer-Heine

CEN Cadarache

13108 Saint Paul lez Durance

FRANCE

Dr. A. Tattegrain

CEN Cadarache

13108 Saint Paul lez Durance

FRANCE

Dr. G. Hache

CEN Cadarache

13108 Saint Paul lez Durance

FRANCE

Jacques Duco

Centre d'Etudes Nucleaires (IPSN-DAS)

Commissariat a l'Energie Atomique

Boite Postale No. 6

F-92265 Fontenay-aux-Roses Cedex

FRANCE

Maurice Gomolinski

Protection and Nuclear Safety Institute

Commissariat a l'Energie Atomique

Boite Postale No. 6

F-92265 Fontenay-aux-Roses Cedex

FRANCE

Michel Livolant

Inst. de Protection et de Surete Nucl. Commissariat a l'Energie Átomique

Boite Postale No. 6

F-92265 Fontenay-aux-Roses Cedex

FRANCE 
Jorma V. Sandberg

Department of Nuclear Safety

Finnish Center Radiation \& Nucl. Safety

P.O. Box 268

SF-00101 Helsinki

FINLAND

S. Chakraborty

Swiss Federal Nucl. Safety Inspectorate

CH-5303 Wurenlingen

SWITZERLAND

J. Peter Hosemann

Light Water Reactor Safety Program

Paul Scherrer Institute

CH-5232 Viligen PSI

SWITZERLAND

Vladimir Asmolov

I.V. Kurchatov Institute of Atomic Energy

Moscow 123182.

Kurchatov Square

RUSSIA

Lajos Voross

Division of Nuclear \& Power Engineering

Institute for Electric Power Research

POB 233

H-1368 Budapest

HUNGARY

Gianni Petrangeli

Nuclear Safety \& Health Protection

Ente Nazionale Energie Altern ENEA/DISP

Via Vitaliano Brancati, 48

I-00144 Rome

ITALY

Giovanni Saponaro

Natl. Committee for R\&D of Nuclear Energy

Ente Nazionale Energie Altern ENEA/DISP

Via Vitaliano Brancati, 48

I-00144 Rome

ITALY
Jun Sugimoto

Japan Atomic Energy Research Institute

Tokai-mura, Naka-gun

Ibaraki-ken, 319-11

JAPAN

Makoto Naito

Nuclear Safety Engineering Section

Toshiba Corporation

8, Shinsugita-Cho, Isogo-Ku

Yokohama 235

JAPAN

Kenji Takumi

Systems Safety Department

Nuclear Power Engineering Corporation

Fujitakanko Building

17-1, 3-Chome, Toranoinon, Minato-Ku

Tokyo, 105

JAPAN

Povilas Vaisnys

Lithuanian State Nuclear Safety Inspec.

VATESI

Gediminis Prospect 36

Vilnius 2000

LITHUANIA

Jozef Misak

Nucl. Regulatory Authority, Slovak Rep.

P.O. Box 24

82007 Bratislava 27

SLOVAK REPUBLIC

Borut Mavko

P.O. Box 100

Institut Jozef Stefan

Jamova 39

61111 Ljubljana

SLOVENIA

B. Raj Sehgal

Royal Institute of Technology

Nuclear Power Safety

S-100 44 Stockholm

SWEDEN 
Distribution

Peter M. Stoop

Risk and Safety Section

Netherlands Energy Research Foundation

P.O. Box 1

1755 ZG Petten

THE NETHERLANDS

Yanko Yanev

Comm. on the Use of Atomic Energy for

Peaceful Purposes - 69 Shipchenski

Prokhod Blvd., 1574, Sofia

BULGARIA

Miguel Medina Vaillard

Com. Nacional de Seguridad Nucl. Salvag

Colonia Narvarte Delegation B. Juarez

Dr. Abrragan \#779

C.P. 03020

MEXICO

B. Kujal

Nuclear Research Institute plc

CS-250 68 Rez

CZECH SLOVAK FEDERAL REPUBLIC (CSFR)

\author{
SANDIA DISTRIBUTION; \\ MS0338 D. W. Schaeffer (1703) \\ MS0736 N. R. Ortiz (6400) \\ MS0744 W. A. von Riesemann (6403) \\ MS0744 D. A. Powers (6404) \\ MS0748 F. T. Harper (6413) \\ MS0742 J. E. Kelly (6414) \\ MS0745 S. L. Thompson (6418) \\ MS0745 R. M. Summers (6418) \\ MS1137 M. D. Allen (5) (6422) \\ MS1 137 T. K. Blanchat (5) (6422) \\ MS1137 M. Pilch (2) (6422) \\ MS1137 R. T. Nichols (6422) \\ MS1139 K. O. Reil (6423) \\ MS0739 K. E. Washington (6429) \\ MS0739 R. O. Griffith (6429) \\ MS0739 F. J. Davis (6429) \\ MS0899 Technical Library (5) (7141) \\ MS0619 Technical Publications (7151) \\ MS1119 Document Processing (7613-2) \\ for DOE-OSTI (10) \\ MS9018 Central Technical Files \\ (8523-2)
}




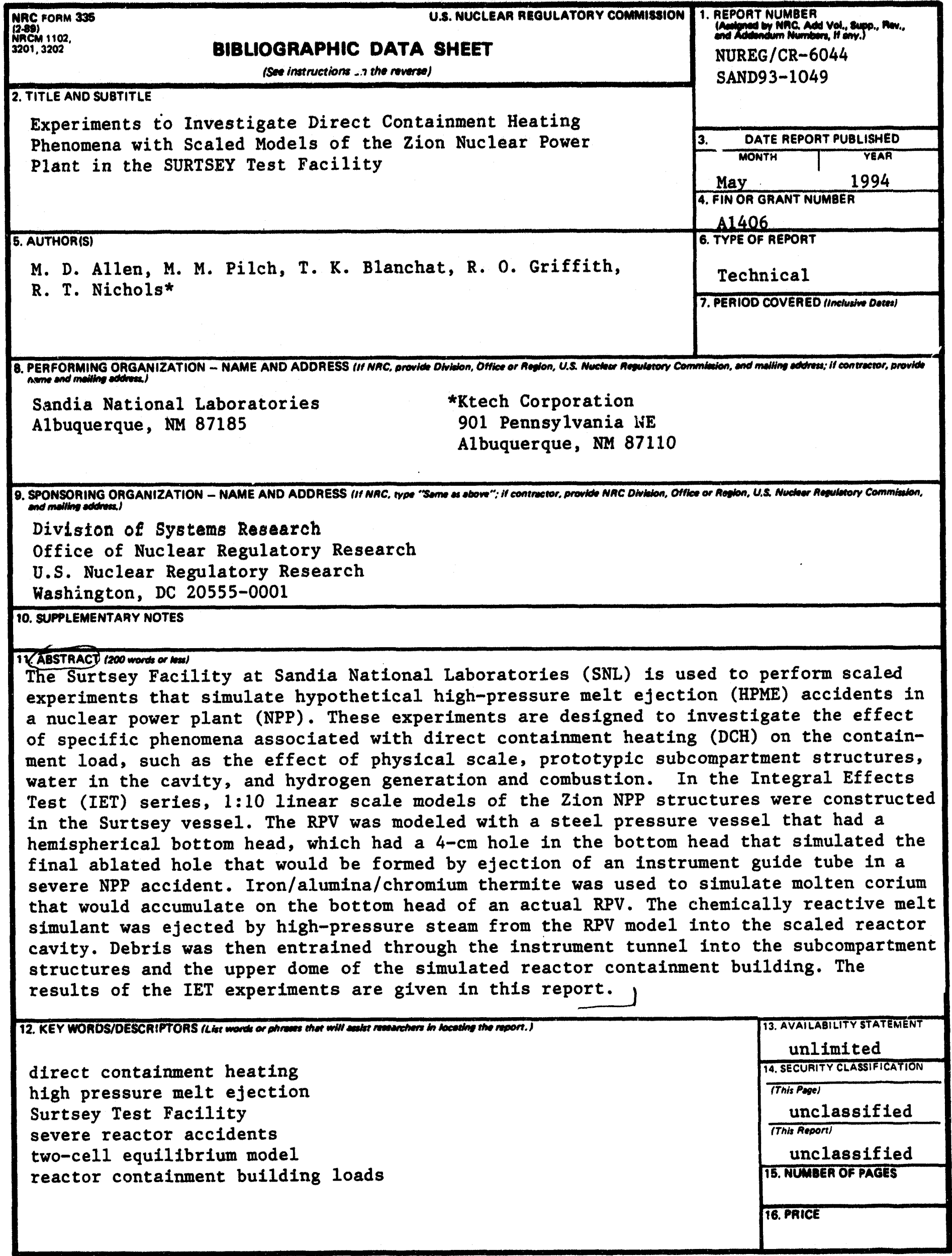



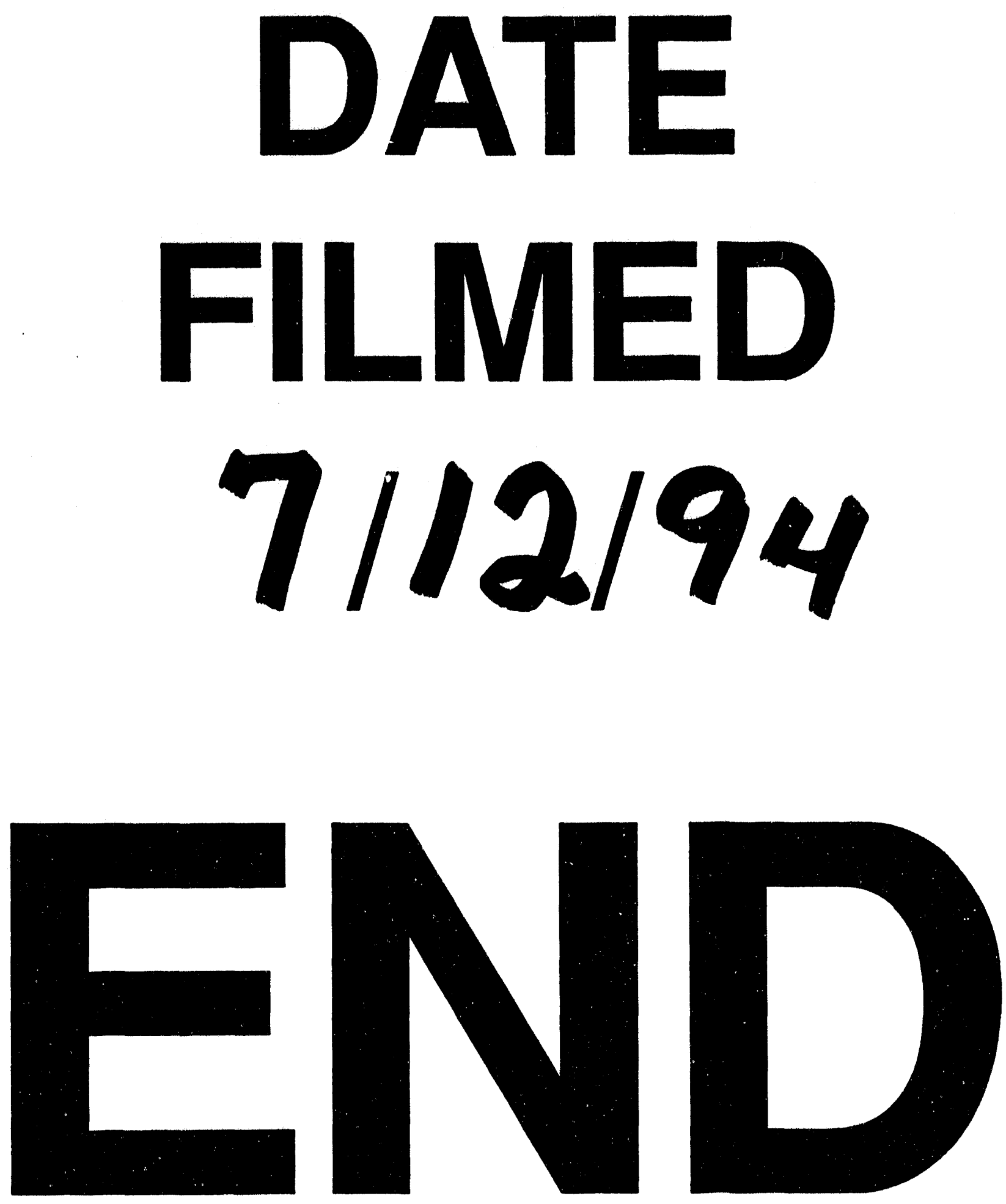
